\title{
Quadros e programas institucionais em políticas públicas
}

\author{
Delma Pessanha Neves \\ Ramonildes A. Gomes \\ Pedro Fonseca Leal \\ (orgs.)
}

SciELO Books / SciELO Livros / SciELO Libros

NEVES, DP., GOMES, RA., and LEAL, PF., orgs. Quadros e programas institucionais em políticas públicas [online]. Campina Grande: EDUEPB, 2014, 260p. ISBN. Available from SciELO Books $<$ http://books.scielo.org $>$.

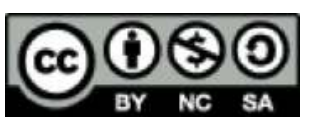

All the contents of this chapter, except where otherwise noted, is licensed under a Creative Commons Attribution-Non Commercial-ShareAlike 3.0 Unported.

Todo o conteúdo deste capítulo, exceto quando houver ressalva, é publicado sob a licença Creative Commons Atribuição - Uso Não Comercial - Partilha nos Mesmos Termos 3.0 Não adaptada.

Todo el contenido de este capítulo, excepto donde se indique lo contrario, está bajo licencia de la licencia Creative Commons Reconocimento-NoComercial-CompartirIgual 3.0 Unported. 


\section{Quadros e}

Programas

Institucionais em

Políticas Púlblicas

Delma Pessanha Neves

Ramonildes A. Gomes

Pedro Fonseca Leal

(Orgs.)

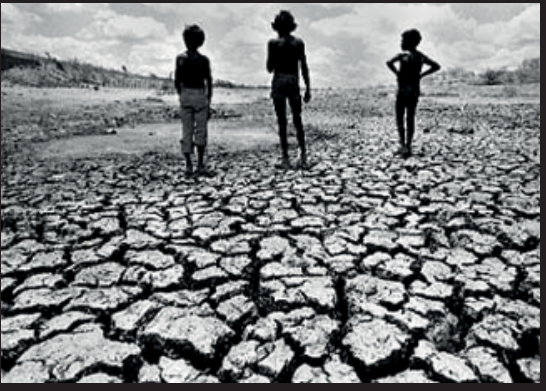

Beduepb 


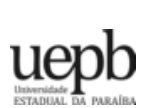

\&eduepb
Universidade Estadual da Paraíba

Prof. Antônio Guedes Rangel Júnior | Reitor

Prof. José Ethan de Lucena Barbosa | Vice-Reitor

Editora da Universidade Estadual da Paraíba

Cidoval Morais de Sousa | Diretor

\section{Conselho Editorial}

\section{Presidente}

Cidoval Morais de Sousa

\section{Conselho Científico}

Alberto Soares Melo Hermes Magalhães Tavares José Esteban Castro José Etham de Lucena Barbosa José Tavares de Sousa Marcionila Fernandes

Olival Freire Jr

Roberto Mauro Cortez Motta

\section{Editores Assistentes}

Arão de Azevedo Souza

Antonio Roberto Faustino da Costa

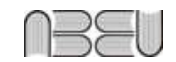

Editora filiada a ABEU

\section{EDITORA DA UNIVERSIDADE ESTADUAL DA PARAÍBA}

Rua Baraúnas, 351 - Bairro Universitário - Campina Grande-PB - CEP 58429-500 Fone/Fax: (83) 3315-3381 - http://eduepb.uepb.edu.br - email: eduepb@uepb.edu.br 
Delma Pessanha Neves

Ramonildes A. Gomes

Pedro Fonseca Leal

(Organizadores)

\section{Quadros e Programas Institucionais em Políticas Públicas}

\section{Seduepb}

Campina Grande-PB

2014 
Copyright $\odot$ EDUEPB

A reprodução não-autorizada desta publicação, por qualquer meio, seja total ou parcial, constitui violação da Lei $n^{\circ}$ 9.610/98.

A EDUEPB segue o acordo ortográfico da Língua Portuguesa de 1990, em vigor no Brasil, desde 2009.

\title{
Editora da Universidade Estadual da Paraíba
}

\author{
Cidoval Morais de Sousa | Diretor \\ Arão de Azevêdo Souza | Editor Assistente de projetos visuais \\ Antonio Roberto F. da Costa | Editor Assistente de Conteúdo
}

\author{
Design Gráfico \\ Erick Ferreira Cabral \\ Jefferson Ricardo Lima Araujo Nunes \\ Lediana Costa \\ Leonardo Ramos Araujo
}

Comercialização

Álisson Albuquerque Egito

Divulgação

Zoraide Barbosa de Oliveira Pereira

\section{Revisão Linguística}

Elizete Amaral de Medeiros

\section{Normalização Técnica}

Jane Pompilo dos Santos

Depósito legal na Biblioteca Nacional, conforme decreto nº 1.825 , de 20 de dezembro de 1907.

FICHA CATALOGRÁFICA ELABORADA PELA BIBLIOTECA CENTRAL - UEPB

320.6

Q1 Quadros e programas institucionais em políticas públicas./ Delma Pessanha Neves, Ramonildes A. Gomes, Pedro Fonseca Leal. (Organizadores). - Campina Grande: EDUEPB, 2014.

$183 \mathrm{p}$.

\section{ISBN 978-85-7879-198-8}

1. Políticas públicas. 2. PAA. 3. Movimentos sociais. I. NEVES, Delma Pessanha. II. GOMES,Ramonildes A. III. LEAL, Pedro Fonseca. IV. Título. 


\section{Sumário}

Apresentaç̃ão

\section{-Parte 1-}

Quadros Institucionais e configurações de Políticas Públicas

15

Delma Pessanha Neves

I - Convivência com o semiárido: um novo paradigma

para Políticas Públicas no Nordeste?

Luis Henrique Cunha

Jonatta Sousa Paulino

II - Quadros Institucionais para a reprodução do Campesinato na Transamazônica.

Alcione Sousa de Meneses

III - O Centro Agroambiental do Tocantins (CAT): concepções situacionais de desenvolvimento rural para a região de Marabá - PA

Luciano Leal Almeida

IV - Incra como Ator-Rede: estudo das relações entre os servidores da SR-27 


\section{-Parte 2.}

Modos de Objetivação de Programas Públicos:

o PAA em foco

127

Ramonildes Gomes

V - Diferenciaç̃ões entre agricultores familiares em

Lagoa Seca: PAA, Mercados Institucionais e

Desenvolvimento Rural

133

Manuel Pereira do Nascimento Neto

VI - Nas Redes do Movimento de Organizacão Comunitária (MOC):

um estudo do programa de aquisição de alimentos (PAA)

na região sisaleira da Bahia

159

Jaqueline da Luz Ferreira

Patrícia dos Santos Pinheiro

VII - Mediação social em projetos de desenvolvimento:

os ADRS e a caprinocultura leiteira no cariri paraibano

Valdênio Meneses

Ramonildes Gomes 


\section{- Parte 3 -}

Políticas Públicas e Conversões Sociais:

os beneficiários em cena

Pedro Fonseca Leal

VIII - Gestão Ambiental e desautorizações dos moradores em RDS:

Reserva de Desenvolvimento Sustentável - do Rio Negro-AM........219

Gimima Beatriz Melo da Silva

IX - Rearranjos locais no programa de reforma agrária: estudo de caso do P.A. Che Guevara (Campos dos Goytacazes, RJ)

Rodrigo Pennutt da Cruz 



\section{Apresentação}

Dentre um conjunto de termos portadores de significados altamente densos - e assim condutores de atributos de sentido fortemente sintéticos e ambíguos, destaca-se o de políticas públicas. Num país como o Brasil, de desigualdades socioeconômicas altamente reconhecidas e de recorrentes retomadas de institucionalização de processos de organização social democrática, a conquista de regulações é altamente reclamada. Nesse sentido, o termo política pública, na concepção de senso comum, quase sempre referenciada a espaço de produção de regras e orientações formalmente institucionalizadas, tende a reafirmar ou reclamar a segurança relativa de conquistas obtidas em disputas de interesses tão desigualmente expressos. Diversos grupos políticos clamam por consolidação de meios compensatórios que guardem certa continuidade, possível, em situação democrática, pela definição oficial de projeções mediante o estatuto de políticas públicas. Por essas e outras razões, no senso comum político, ao se reivindicar práticas democráticas, imediatamente elas estão associadas às definições que guardem o caráter de políticas públicas.

Tamanho acordo (ou crença) permite que haja intensas comunicações em torno do tema, mesmo que estejam incorporados diversos e até contrapostos e contraditórios sentidos. Dificilmente ocorre questionamento do que afinal se está assentando no campo da linguagem dos espaços políticos, quando se reivindica a nobreza dos significados do termo, quando nada, ao designar reordenações sociais e prestação de serviços públicos.

O superapelo à crença na imediata evidência de sentido do termo ultrapassa o senso comum no campo político, reafirmando-se 
também no campo acadêmico, onde os procedimentos metodológicos deveriam de imediato colocar, em questão, tamanho processo instituidor dessa ampla aceitação de sentidos comuns e diversos.

No meio universitário, em cursos de pós-graduação na área de ciências sociais, há enorme profusão de textos construídos sobre o tema, mas adotando-se o mesmo acordo. Por consequência, também aí se reproduzem pré-noções que iludem a elaboração de trabalhos descritivos, em consequência dificultando a compreensão dos processos que o termo necessariamente aglutina.

Diante dessa constatação e orientados à construção de espaços de diálogo em que princípios de pensamento possam ultrapassar mesmices e colaborar para o debate teórico e metodológico da temática, propusemos um grupo de trabalho no $5^{\circ}$ Encontro da Rede de Estudos Rurais, ocorrido em Belém, no ano de 2012. Dos muitos textos apresentados, selecionamos alguns deles, não porque necessariamente fossem julgados como os de caráter mais bem acabado. Aos autores propusemos a continuidade do debate. Valorizamos o rendimento que os objetos de estudo apresentados pudessem trazer à reflexão os diversos meandros sociais pressupostos pelo termo políticas públicas, a problematização de sentidos imediatamente dados. Além disso, agregamos alguns outros artigos, considerando os mesmos motivos: produzir reflexões demonstrativas dos múltiplos espaços de definição de regras para circulação de recursos, pautados na construção de quadros institucionais, aqui considerados em duplo sentido. Não só o investimento que processos de construção de políticas públicas pressupõem para objetivar ideários de comportamentos, de redistribuição de recursos, mediante criação de redes interdependentes de aparatos instituições, ou seja, de órgãos pautados para tais fins. Também o pressuposto paralelo e complementar: constituir agentes sociais capazes de, como profissionais dotados de expertise na definição de problemática naqueles termos reconhecida. Enfim, como problema social a ser encarado por prioridade de medidas e correlativas resoluções. Enfim profissionais capazes de operar na formulação e realimentação de ideias referenciais aos modos pelos quais aqueles objetivos alcançam a capilaridade das práticas 
institucionais; na constituição de procedimentos que conformem os que são definidos, veem-se ou desejam ser usufrutuários de tais mudanças na ação pública.

Queremos expressar assim o caráter processual que integra as perspectivas analíticas sobre políticas públicas, de modo a facilitar o reconhecimento de que os compactados sentidos do termo tendem a produzir exclusões no que tangem às ações coletivas; ou dificultar as intervenções inerentes aos projetos de mudanças sociais em jogo. Em consequência, também reafirmaríamos: é do dever da prática democrática facilitar as formas de participação política de segmentos específicos ou amplos, no que diz respeito ao conjunto de mudanças acenadas como promotoras de reordenações sociais respeitosas dos princípios universais da igualdade social e política.

Pautados por esses parâmetros analíticos, organizamos esta coletânea por três grandes eixos. No primeiro deles, aglutinamos reflexões de autores que incidem sobre o estudo da construção de instituições e respectivos agentes, cujas ações visam a atribuir ou alterar sentidos projetados para reordenação da vida social; ou para constituição de ações práticas e segmentos socioeconômicos amparados por direitos de partilha de bens cuja circulação pública depende de definições da autoridade estatal. Convidamos, assim, os leitores a refletir sobre os quadros institucionais (órgãos e agentes sociais) que asseguram a formulação, a delimitação e a operacionalização de ideários e medidas abarcadas pelo termo políticas públicas.

No segundo eixo, agregamos autores que se dedicaram ao estudo de colocação em prática de princípios, objetivos e metas desenhados por políticas públicas, mediante formulação e objetivação de programas públicos. E à guisa de demonstração, ainda destacamos o investimento concentrado em torno de modos de operacionalização que se instituem em programas públicos, no caso o Programa de Aquisição de Alimentos (PAA, 2003 ) recentemente implantado como expressão de conquista de demandas de agricultores familiares, na luta pela reprodução social, política e econômica da categoria socioeconômica. 
E, no terceiro eixo, tomamos alguns casos de reflexão incidente sobre a capilaridade dos segmentos populacionais envolvidos no acesso de recursos ou na institucionalização de posições desenhadas como parte dos objetivos de políticas desdobradas em programas. Podemos, então, percorrer intrincados modos de constituição de princípios de pertencimento ao campo de redistribuição de recursos e de enquadramento que, muitas vezes, exigem formas de conversão social em direções diversas: - reconversões dos modos de percepção e categorização dos que estão autorizados a implementar programas públicos na capilaridade dos espaços reconhecidos como dos chamados beneficiários; - bem como dos que assim se apresentando por desejo próprio ou por imposições, retroagem ou resistem, no sentido de alterar os meios de definição de si como enquadrados. Ambos são exercícios de elaboração coletiva ou de participação política, no campo das ações, amplamente definidos como de políticas públicas.

Nos artigos que aqui agregamos, o leitor estará, então, estimulado a refletir sobre alguns dos modos como ocorrem processos de encontro e negociação objetivados em espaços institucionalizados, considerando seu sentido mais amplo: organizações sociais, mas principalmente o caráter nelas abarcado por sistema de ideias, competências, procedimentos e normatizações. Estaremos, assim, refletindo sobre proposições a serem consideradas pelas formas de constituição das ações do Estado, fundamentadas em negociação com os que politicamente elaboram demandas. Propomos, por isso mesmo, ênfases analíticas sobre os próprios quadros institucionais, mas pensados por espaços de objetivação colocados em prática por agentes que, para tanto, se qualificam em múltiplas dimensões.

Os organizadores. 
Parte 1 



\section{Quadros Institucionais e configurações de Políticas Públicas}

Delma Pessanha Neves ${ }^{1}$

Como vimos afirmando em sintonia com a construção desta coletânea, somos continuamente confrontados à multiplicidade de questões relativas às políticas públicas, isto é, às ações conduzidas, recorrentemente em parceria, pelas autoridades públicas. Somos insistentemente convidados ou motivados a pensar sobre os efeitos sociais das políticas que vêm sendo adotadas por governos nas suas diversas dimensões. Perguntas, então, fervilham nossa curiosidade de pesquisador:

- Como são escolhidos os usufrutuários? Como se desenrola a sucessão de planos diferentes?

- Como se operam os procedimentos mediante normatizações, constituições institucionais, preparação de agentes interventores e os delimitados beneficiários?

- Como as diversas políticas se ajustam para caracterizar intenções anunciadas por porta-vozes do governo? Ou para atender à qualificação de demandas elaboradas por canalização de interesses de grupos interessados em compor agendas políticas? Por que, recorrentemente, somos levados a anunciar, mesmo com

1 Professora do PPGA - UFF e PVNS - UFOPA 
antecedência, isto é, pela leitura das proposições, o destino do fracasso ou da irrealidade das intenções prenunciadas?

Essas perguntas remetem à importância do entendimento dos modos de funcionamento das instituições estatais. Além disso, revelam nossas intenções ou tentativas de mudar jogos de forças sociais interpretados como conjunturas específicas. Somos, então, suscitados a criar outras configurações de sentidos e campos de disputas, assegurados por outros emergentes quadros institucionais, isto é, órgãos e agentes pertinentes a tarefas determinadas.

Portanto, a capacidade de intervir nessa dinâmica social não é autoevidente, exigindo formação especial e competência para os múltiplos exercícios de mediação que se fazem necessários. Por isso mesmo, estudar ou analisar políticas públicas é se construir para adoção de perspectivas processuais e por olhares capazes de perceber relações sociais em redes, interdependentes e transversais.

Essa atribuição esperada dos cientistas sociais vem se ampliando, na medida em que nos comprometemos com a construção de modos de governo das sociedades contemporâneas. Ou que passamos a considerar fundamental entender como os governos agem e sob que intenções se fundamentam para assim agir e mudar. Como se constituem as inerentes defasagens entre o que se deseja - tal como formulado em textos imediatos ou mediadores da explicitação das justificativas, de definição de problemas e modos de resolução? E o que se torna plausível de provisórias realizações? Enfim, como entender tais disjunções, na medida em que a realização de políticas pressupõe negociações com resistências, (re)significações e atribuições de sentidos outros, não previstos ou mesmo indesejados pelos formuladores daqueles necessariamente prévios princípios públicos (nem sempre tão públicos) de ação?

Não sendo da ordem da evidência, por agregar sentidos diversos, o termo ou conceito (política pública) não pode ser responsabilizado, imaginando-se que ele mesmo possa se apresentar como produtor de um único sentido. Ao reunirmos os três próximos artigos para refletir sobre alguns desses aspectos, ou melhor, para considerar alguma dessas complexidades, é fundamental e coerente assumirmos uma definição possível para embasar as 
questões levantadas. Como definição suporta críticas, avaliação de limites de pertinência e controvérsias, afinal pode ser construída por diferentes aportes científicos, adotamos certa economia de investimentos, reafirmando a intenção de assegurar sintonias com os leitores. Mais que isto, também para facilitar reflexões em torno da importância da constituição dos quadros institucionais que subjazem às sociedades democráticas em que há reclamos quanto a políticas públicas.

Segundo Kubler e Maiilard (2009), os debates quanto ao conceito são muitos, mas há alguns pontos de aproximação, como os explicitados por Thoenig (1993): Uma política pública se apresenta sob a forma de um programa de ação próprio a uma ou várias autoridades públicas ou governamentais.

E neste caso, destacam os autores, vários critérios são importantes de serem considerados:

- O papel de uma autoridade pública ou de várias autoridades públicas.

Segundo Thoenig (1993), a política pública não o é quando corresponde a formas de programas de ação de uma empresa ou de uma associação. Para colocar em prática uma política, só as autoridades públicas dispõem da capacidade potencial de utilização da violência legítima.

- A existência de um programa com medidas pressupostamente objetivas, que podem ser coercitivas, incitativas, distributivas, etc.

A existência de política pública supõe, relativamente, certa coerência entre várias ações governamentais. Uma simples decisão administrativa não basta para ser política pública. É necessário que haja um conjunto de decisões interligadas ou interdependentes, ações em parcerias. Por isso, o termo política pública engloba um programa de ação governamental. Por exemplo: coordenação específica de leis, explicitações e dotações de crédito, administração e pessoal dirigidos para um conjunto de objetivos mais ou menos claramente definidos. Na prática, adverte o autor, essa coerência geralmente é mal definida. Atrás da unidade de um programa de ações, podem se acolher concorrências administrativas, uma pluralidade de ações de sentidos próprios e sem ligação entre elas, 
apenas reunidos formalmente no seio de um mesmo programa. Desde logo, então, a questão da coerência dos programas de ação pública deve se tornar problemática de pesquisa, sem que se caia na crença da relação imediata entre o dito e o feito, o anunciado e o executado.

Diante de tamanha complexidade analítica, é de se entender os riscos das simplificações, sistematizações, sintetizações e vulgarizações. Diante do afã de definições de práticas democráticas, não só daquelas que prescrevem efeitos excludentes, tal como ocorre com práticas inerentes aos programas estatais de cunho neoliberal, exalta-se nosso empenho em construir os marcos de sociedade democratizante. Correlativamente, é também de se entender o efervescente investimento político na regulação da vida social ou coletiva, na definição de novos parâmetros de nação. Por tais razões, outro princípio de método se reafirma no estudo da temática: as problemáticas práticas e acadêmicas, suscitadas pela demanda proliferada de ações enquadradas como políticas públicas, impõem a exigência da contextualização desses processos, redefinindo conceitos e perspectivas.

O campo de construção da análise de políticas públicas é datado. É nos EUA, nos anos 1930, que emergem os primeiros trabalhos de análise reconhecidos como de políticas públicas. Os projetos de intervenção pública do governo federal americano tenderam, então, a ser dissecados por análises diversas. O contextual investimento, intelectual e político, partia do pressuposto pragmático de que era preciso compreender para agir. A análise das políticas públicas fora, assim, construída pela perspectiva de que é preciso ajudar aos que decidem, enquanto autoridade pública, a fazer boas escolhas políticas. Nas ciências políticas, que basicamente incorporaram e se reconstituíram com a temática, os estudiosos mobilizaram o apoio e a reorientação de uma multiplicidade de disciplinas científicas. Esses investimentos vieram a produzir reconhecida expertise para a contribuição na resolução de problemas. Os intelectuais que aderiram ao tema enfrentaram, então, a perspectiva, alçada a princípio de valor e legitimidade metodológica, de separação de práticas acadêmicas e visões pessoais; ou 
valorização da tradicional dicotomia entre o intelectual e o político. Legitimou-se, assim, sob diversas controvérsias, a proposição de um saber engajado, neste caso, saudado pelo exercício da crítica e da avaliação, definidas como condições de compreensão ou apreensão dos sentidos da ação governamental.

Nos demais países de constituição relativamente pioneira dos campos acadêmicos e das especializações em ciências sociais, a adesão de cientistas sociais ocorreu por volta da metade dos anos 1970 e 1980, em alguns casos com problemáticas bastante distanciadas daquelas assumidas na ciência política nos Estados Unidos. Uma das contraposições às problemáticas assumidas nas ciências sociais, especialmente políticas, nos Estados Unidos, abarcou a construção de novos objetos de estudo pela perspectiva da sociologia do Estado. Nas pesquisas correspondentes, advogava-se como objetivo construir uma imagem mais realista da ação do Estado, isto é, demonstrar como a instituição se fundamenta por tensões contraditórias. E ainda se colocava em causa uma (por vezes) simplista visão marxista, bastante reconhecida, na época, pela definição do Estado tão-somente com máquina a serviço da classe dirigente.

Por tais posturas, muitos desses pesquisadores desenvolveram estudos incidentes sobre as estratégias e as relações de poder no seio das administrações. E, assim, demonstraram o caráter muito fragmentário da administração, insistindo nas oscilações de concorrência e dos grandes corpos das diferentes organizações administrativas, assim como as práticas informais e os arranjos constitutivos do (e no) mesmo sistema de ação. Outros, ainda, insistiram na evidência de fatores ideológicos da ação pública, nos modos de regulação mais globais da sociedade, reconhecendo a dimensão propriamente política das políticas públicas.

No início dos anos 1980, aparecem então as primeiras obras centrais da análise da ação pública, sendo emblemática, neste aspecto, a publicação de Jean-Gustave Padioleau, L'Etat au concret (1982), texto em que o autor importa as teorias sociológicas americanas para a ação do Estado na França e coloca, em questão, a imagem tradicional de um Estado uniforme, cujas decisões se impõem à sociedade. Hoje este é um domínio importante da pesquisa em ciência política 
e sociologia, notadamente; conhecimentos acumulados aos quais, de forma direta ou mesmo não muito conscientemente, diversos autores vêm se agregando ou reafirmando o que pode ser considerado um "senso comum" no campo científico.

Por conseguinte, a análise de políticas públicas cresce com o desenvolvimento do intervencionismo do Estado, tal como demonstram diversos autores brasileiros que acompanharam esse processo, estudando, inicialmente, para permanecermos no domínio do setor agropecuário, as políticas de controle da produção sucroalcooleira e da cafeicultura, investimentos estatais pródigos na constituição de aparatos institucionais, partes constitutivas das ações reconhecidas como procedimentos de políticas públicas.

Ao valorizarmos a reflexão sobre os modos de institucionalização, seja por criação de órgãos ou agentes, também propomos evitar generalizações fundamentadas em abstrações idealizadas, dado que elas impedem de compreender os modos de operacionalização de políticas públicas. Além disso, elas conduzem os pesquisadores ao risco de se pensarem capazes de propor por si mesmos a melhor sociedade e o melhor funcionamento do Estado.

Destacamos, no caso brasileiro, outros fatores que estimulam a expansão do estudo de políticas públicas: as sucessivas tentativas do Estado brasileiro de cumprir as promessas de redemocratização, instituídas na Constituição de 1988 e, por consequência, as pontuais, complementares, contraditórias e também articuladas investidas para reafirmar o Estado Social. Com essa expressão queremos acentuar as intervenções públicas (econômicas e sociais) reconhecidas pelo caráter redistributivo de bolsas, destinadas a diversos fins (escolares, benefício continuado, bolsa família, bolsa floresta, etc.).

Como demonstram os três autores dos respectivos artigos que compõem esta primeira seção, são variadas as condições nas quais as decisões são tomadas, bem como a invenção ou adoção de instrumentos de ação pública. Além disso, a ação do Estado vai se diversificando, a ponto de o setor público cada vez mais comportar um conjunto heterogêneo de ações e contratação de parcerias, correspondendo a sucessivas e coexistentes atividades e modos de gestão. 
No entanto, não só tais aspectos estão sendo aqui por nós considerados. É importante, segundo nosso juízo, avaliarmos os significados em termos da prática científica e da construção de campos temáticos e acadêmicos, que também interferem nas condições de análise. Ao mesmo tempo, eles jogam sentidos sobre o estudo na modalidade avaliação e compreensão de práxis das operações correspondentes às políticas públicas.

Aos estudos de comportamentos de atores políticos, incorporamos, nesta primeira seção, o das organizações ou das instituições, considerando como objeto de reflexão as tomadas de decisão, a elaboração de critérios de inclusão e exclusão, mas também os modos como os que se querem integrados ao quadro de tais programas públicos, insistem na mudança de perspectivas, de métodos, de dotações orçamentárias e na expansão de serviços e recursos a serem circulados.

Estamos, assim, longe daquelas perspectivas analíticas pautadas em princípios filosóficos que autorizavam os estudiosos à projeção de sociedades por vir; ao cumprimento de normas, como se pudessem corresponder tal e qual às práticas; ou das pretensões dos estudiosos que se pensavam acima do bem e do mal. Cada vez mais levamos em consideração nosso papel de intérprete de dados colhidos sob condições a serem explicitadas, porque eles ganham sentidos nas situações em que eles foram valorizados para a interpretação. Tomamos, assim, como objeto de estudo a demonstração do funcionamento das atividades e dos espaços assumidos ou reivindicados por diferentes participantes. As interações correspondentes devem ser valorizadas no interior das instituições, mas também pelos (espaços) que correspondem a formas de pressão, no sentido de melhor adequá-las ou de minimizar as predominantes interferências de funcionários, em seus mais diversos planos de elaboração, normatização e ação. Enfim, valorizando a explicitação das perspectivas adotadas pelos autores que integram esta parte da coletânea, deixamos cada vez mais de lado as intenções que subjazem aos julgamentos de valor, para entendermos como os fatos ou fenômenos se constituem por múltiplas interferências e interveniências. 
Nos três artigos que compõem esta primeira parte da coletânea, os autores valorizam o estudo de modos de ação de agentes mediadores, abarcando diversos domínios de relações: a) Agentes de intervenção na formação de quadros institucionais, tomando em conta, em certos casos, perspectivas desenhadas e atribuídas aos agricultores. Portanto, os autores valorizam o papel da mediação na inserção do ponto de vista dos agricultores quanto à constituição das instituições, dos respectivos funcionários e segmentos a serem atingidos, segundo objetivos por eles desejados.

Alcione Sousa de Meneses e Luciano Leal Almeida enfatizam a importância do estudo da ação coletiva (por vezes, mediante a forma de movimentos sociais) para induzir funcionários do Estado à criação de instituições, mas segundo formas de negociação do modelo de agricultura e de agricultor a ser proposto e oficialmente reconhecido.

Ao adotarem tal perspectiva, destacam as ações interdependentes de agentes vinculados a igrejas e sindicatos, protagonistas de movimentos sociais cujas pautas de interveniência contemplam a formação dos sucessores ou a definição dos termos da socialização profissional. Enfim, colocam em questão as problemáticas intergeracionais que constrangem a reprodução de projetos políticos e familiares. Em consequência, destacam a necessidade de investimento do pesquisador na compreensão do diálogo e da correspondente inserção em instituições que permitam ultrapassar o domínio de relações familiares, comunitárias e religiosas, ou mesmo a sociabilidade intergeracional.

Alcione Sousa de Meneses analisa «ações públicas e coletivas que vieram a produzir convergências de investimentos propiciadores da construção de quadros institucionais". E adverte: investimentos "pautados na correspondente dotação de agentes sociais constituídos para garantir competências capazes de projetar recursos e serviços elaborados segundo percepção de mundo valorativa da posição de agricultores familiares'.

Embora Alcione e Luciano focalizem estudos de casos em municípios diferentes do Estado do Pará, na prática, estão diante de um mesmo campo político e acadêmico, com incidência de profissionais 
vinculados à Universidade Federal do Pará, a instituições religiosas, apoiadas por parcerias com outras tantas de ação mais internacional. Todos os autores estão tomando como base empírica a ação de colonos que reagiram ao risco de perda de múltiplos investimentos na reprodução como campesinato; ou de abandono do projeto estatal cuja envergadura mobilizou deslocamentos populacionais de efeitos altamente significativos nas condições de reprodução social dos que assim se engajaram.

Tanto em Altamira como em Marabá, agricultores se organizaram para conceber a constituição de instituições que viessem a respaldar os projetos de reprodução dos filhos na posição, sem que se apresentassem como herdeiros de um passado de improvisação e de tentativas frustradas. Investiram, então, na construção de identidade profissional e na condição de agente econômico com base em ações políticas que respaldassem a sociedade então desejada.

A integração do artigo permite pensar esses processos de constituição governamental de agricultores no município de Marabá, mas tomando em consideração as disputas internas aos funcionários do INCRA, confrontados a mudanças de práticas e ideários diante de mudanças conjunturais nos modos de organização política da sociedade e dos agricultores.

Como a própria autora destaca, o INCRA representa instituição de grande peso nos rumos da aplicação da proposta de reforma agrária, mas tem sido pouco estudada no que tange ao funcionamento interno. Tomando este caso para reflexão, a autora contribui sobremaneira para a compreensão dos modos de expressão de disputas políticas de funcionários que aí se constituíram por tomadas de posições favoráveis ou desfavoráveis à reforma agrária. Dadas as dificuldades de acompanhamento (por pesquisa) dos confrontos internos à instituição, a autora constrói significativa estratégia de coleta de dados, ao adotar diversas situações explicitadoras de controvérsias e de interferências de outras instituições, como os representantes delegados de movimentos sociais e de partidos políticos.

Os três artigos correspondem, assim, a uma excelente oportunidade de refletirmos sobre casos incidentes em campos políticos 
tangenciais, em modos complexificados de constituição de tecidos institucionais e de desdobramentos de ações de agentes associados ou contrapostos a formas de constituição e reprodução de agricultores no Estado do Pará.

Para analisarem desdobramentos das ações coletivas que venham a configurar políticas públicas, os autores se dedicam ao estudo de mediadores burocratas, profissionalizados, experts na elaboração e operacionalização de políticas públicas; bem como ao peso que as disputas institucionais internas às relações entre funcionários terminam por moldar desdobramentos nem de longe tangenciados pelos ideários de políticas e programas públicos.

Por conseguinte, a levar em considerações alguns dos diversos meandros das formas de elaboração e implementação de ideários qualificados como políticas públicas, é relevante se pensar nos conflitos interinstitucionais na operacionalização de programas públicos, isto é, conflitos entre instituições de ações paralelas, articuladas por contratação de parcerias. Em consequência, se as ações em parcerias são concebidas para facilitar as práticas públicas, tais objetivos, muitas vezes, só podem ser alcançados pela gestão de dificuldades de construção e reprodução de interdependências por complementação, diante de formas de concorrência e imposições de regras e lógicas. Enfim, há que se considerarem as relações de poder no interior do campo da agregação institucional.

Todos os autores que integram esta seção colocam, em relevo, a dimensão cognitiva das políticas públicas, demonstrando um conjunto de demandas e interferências no sentido da construção de profissionais adequados ao espaço social em que as instituições devem se construir e interferir. Eles analisam, assim, alguns dos processos de aprendizagem na construção de atores sociais referenciados a práticas mediadoras, construção de usuários dos serviços públicos e comunitários. 


\section{Referências}

KUBLER, Daniel; MAIILARD, Jacques de. Analyser les politiques publiques. Grenoble: Presses Universitaires de Glenoble, 2009.

PADIOLEAU, Jean Gustave. L'Etat au concret. Paris: Puf, 1982.

THOENIG, Jean Claude. L'Analyse des politiques publiques, in J. Leca \&M. Grawitz (dir.), Traité de Science Polique. Paris: Puf. tome 4, p.160. (s/d). 



\title{
I
}

\section{Convivência com o semiárido: um novo paradigma para Políticas Públicas no Nordeste?}

\author{
Luis Henrique Cunha ${ }^{2}$ \\ Jonatta Sousa Paulino ${ }^{3}$
}

\section{Introdução}

No dia 11 de julho de 2012, a presidenta do Conselho Nacional de Segurança Alimentar e Nutricional (CONSEA), Maria Emília Lisboa Pacheco, encaminhou correspondência à Presidenta da República, Dilma Rousseff, na qual apresentou "proposições relativas às estratégias de convivência com o Semiárido" no quadro das preocupações quanto aos efeitos da ocorrência de mais uma seca no Nordeste brasileiro. No documento de 10 páginas, o termo convivência, normalmente seguido da expressão "com o Semiárido", é mencionado 15 vezes $^{4}$. No último parágrafo, o CONSEA propõe "a construção participativa de uma Política Nacional de Convivência com o Semiárido, de caráter permanente", repercutindo outro documento, elaborado pela Câmara Interministerial de Segurança Alimentar e Nutricional (CAISAN), intitulado "Ações do Governo

2 Doutor em Desenvolvimento Socioambiental, professor do PPGCS/UFCG e do PPGDR/UEPB. luishcunha@uol.com.br

3 Doutorando em Ciências Sociais, UFCG. Jonatta.15@bol.com.br

4 Há ainda duas menções à expressão "conviver com o Semiárido". 
Federal para a Promoção da Convivência com o Semiárido" (PACHECO, 2012).

A reunião que aprovou o envio de correspondência pelo CONSEA à Presidência da República foi noticiada no site da Articulação do Semiárido (ASA BRASIL), no qual se informava que "a proposta defendida pela sociedade civil para o desenvolvimento sustentável do Semiárido - a convivência com a região, ao invés de ações de combate à seca - foi tema central de discussão" no CONSEA. A jornalista informava, ainda, que a plenária teve a "participação inédita de uma agricultora familiar do Semiárido", Joelma Pereira, ao lado da ministra do Desenvolvimento Social e Combate à Fome, Tereza Campello, e de representantes de outros ministérios (PRAGANA, 2012).

Tanto a correspondência do CONSEA quanto a notícia veiculada pela ASA Brasil se referem a um "paradigma da convivência", podendo-se entender, com isso, que a convivência com o semiárido conformaria um modelo (de desenvolvimento) capaz de orientar e dar coerência a escolhas, ações e políticas. Para muitos autores e atores sociais, a adoção da perspectiva da convivência tem levado a mutações significativas nas formas de intervenção no semiárido (SILVA, 2007; NASCIMENTO, 2008).

Este capítulo tem um duplo objetivo: de um lado, tornar mais claros os pressupostos sobre os quais se assenta esse "novo" paradigma, destacando o que consideramos serem suas premissas "conservantistas", cujas tensões não refletidas entre inovação e tradicionalismo resultam num conservadorismo de vanguarda; e, de outro lado, inventariar quais escolhas têm sido feitas e quais ações e políticas públicas têm sido propostas sob a influência da ideia de convivência com o semiárido e propor uma reflexão sobre as consequências destas escolhas, ações e políticas nos termos do que chamamos de "excepcionalismo ${ }^{5}$ dos pobres". Tentamos demonstrar, assim, que as políticas de convivência com o semiárido informam, principalmente, uma estratégia de ação voltada para uma parcela da sociedade - populações rurais e de peque-

5 Por excepcionalismo entendemos a opção, implícita ou explícita, de considerar certos grupos humanos de algum modo excepcionais, devendo ter, portanto, um tratamento diferenciado. 
nos municípios historicamente marginalizados das dinâmicas de modernização/desenvolvimento - que objetiva mantê-los como um grupo diferenciado tanto em termos socioculturais quanto de suas relações com a natureza.

Inspirados por Boltanski e Chiapello (2009), interpretamos a emergência e difusão da ideia de convivência com o semiárido em termos de uma "ideologia que justifica o engajamento" de diferentes atores a conjuntos particulares de propostas políticas. Neste sentido, foi necessário um trabalho de "mobilização ideológica" que produzisse "adesão ativa" ao que se considera um paradigma alternativo de promoção do desenvolvimento, em substituição ao criticado paradigma de combate à seca.

A realização das tarefas a que nos propomos neste texto leva à reflexão acerca da relação entre a sociologia e o mundo social que ela busca desvelar e sobre o papel dos cientistas sociais neste mundo e na produção de alternativas de mudança social. Há um papel a desempenhar pelas ciências sociais na luta contra a dominação, desigualdade, pobreza e injustiça social? Há aqueles que preferem o engajamento direto, o contato com os atores sociais como intelectuais orgânicos, e há aqueles que (como Elias e Bourdieu) problematizam essas relações e defendem um desengajamento emocional em relação às situações sociais objetivadas pela pesquisa científica, como melhor forma de contribuir politicamente (mesmo que essa posição não seja, também ela, totalmente livre de contradições). Nossa própria visão do problema é influenciada por esta última posição.

Interessa-nos "a análise da dominação simbólica - a dominação que não é reconhecida como tal” (BURAWOY, 2010, p. 26), ou seja, uma análise da violência simbólica, ativada e atualizada justamente nos processos de produção dos discursos. Burawoy (2010, p. 26), seguindo Bourdieu, afirma que "conhecer melhor as condições de produção do conhecimento é a condição para a produção de um conhecimento melhor". A crítica permanente dos elementos ideológicos mobilizados nas políticas de desenvolvimento parece um bom ponto de partida para o engajamento dos cientistas sociais nos processos de transformação social. 


\section{Convivência como adaptação: pressupostos conservantistas de um novo paradigma}

A noção de convivência com o semiárido tem sido defendida como um "paradigma emergente" ou como um "novo paradigma civilizatório” (SILVA, 2007; MALVEZZI, 2007; CHACON, 2007). De um lado, a crença que se está constituindo uma alternativa às formas consolidadas de considerar os desafios relativos ao desenvolvimento regional - em que o "problema" da seca era um dos principais entraves a superar; e de outro lado, o comprometimento com um novo modo de viver na região. Assim, a ideia de convivência significaria tanto uma crítica a determinadas práticas sociais - expressas tanto numa forma de perceber o semiárido quanto em diferentes maneiras de agir sobre este espaço/território - quanto uma normatividade específica - que recorre a certas categorias de percepção para informar certas práticas e, ao que nos interessa neste texto, políticas.

Também é recorrente a associação entre sustentabilidade e convivência com o semiárido. A noção de convivência seria, então, um desdobramento das preocupações ambientais, ou, mais precisamente, uma maneira de especificar, para o semiárido, o tema do desenvolvimento sustentável (SILVA, 2007). Para Nascimento (2008, p.2), o paradigma da convivência com o semiárido não pode ser reduzido a seu aspecto socioeconômico, pois se trata de uma concepção socioespacial e, como tal, traduz uma interação ser humano-território-natureza.

Em texto publicado em 2001, dois pesquisadores da Embrapa Semiárido, sediados em Petrolina (PE), Clóvis Guimarães Filho e Paulo Roberto Coelho Lopes, buscam apresentar subsídios para um programa de "convivência com a seca". E, neste contexto, já anunciam o que poderia significar o tal programa: "a busca de sistemas produtivos ou formas de uso que se harmonizem com o meio -ambiente do Semi-Árido" ou a "adequação agroecológica" das alternativas produtivas apresentadas para a região (GUIMARÃES 
FILHO; LOPES, 2001) $)^{6}$. É importante ressaltar que, no paradigma da convivência, estão relacionadas duas dimensões: uma dimensão social (num sentido amplo que envolve tanto práticas produtivas quanto saberes e especificidades culturais) e outra ambiental. A dimensão social deve se "adequar" à dimensão ambiental.

Malvezzi (2007) fala em "boa convivência com o ambiente", para então referir-se explicitamente ao que nos parece ser o núcleo central da ideia de convivência: a noção de adaptação ${ }^{7}$. Segundo ele:

Está em gestação um novo conceito civilizatório para a região: a convivência com o Semi-Árido. A ideia parte de um princípio simples: por que os povos do gelo podem viver bem no gelo, os povos do deserto podem viver bem no deserto, os povos das ilhas podem viver bem nas ilhas e a população da região semi-árida vive mal aqui? É porque aqueles povos desenvolveram culturas de convivência adequadas ao ambiente, adaptaram-se a

6 As propostas apresentadas por Guimarães Filho e Lopes (2001) não são totalmente respaldadas nos textos mais recentes sobre o tema. Os autores chegam a falar, inclusive, no aumento da eficiência da irrigação e na construção de novos açudes na região, mas a concepção geral do que seria convivência é a mesma, em linhas gerais, que a encontrada na literatura posterior. O texto de Suassuna (2002) é outro exemplo do uso da ideia de convivência numa chave mais explícita de modernização e solução hídrica.

7 A noção de adaptação é central para as abordagens da ecologia humana e da antropologia ecológica. Estas correntes de pensamento parecem ser as influências não reconhecidas do paradigma da convivência. Um dos pressupostos fundamentais da ecologia humana é o de que os indivíduos adaptam seus comportamentos aos ambientes em que vivem (WOHLWILL, 1973). A antropologia ecológica é fortemente influenciada pelo trabalho de Roy Rappaport, para quem as populações humanas desenvolvem mecanismos culturais de adaptação ao ambiente. Todas estas abordagens foram objeto de intensa crítica no campo das ciências sociais e pretendemos, em outro artigo, aprofundar a relação entre a ideia de convivência com o semiárido e estas abordagens. 
ele e tornaram viável a vida. No Semi-Árido brasileiro, essa integração de pessoa e natureza não encontrou uma solução adequada, de modo que o ser humano permaneceu sujeito às variações normais do clima regional.

O segredo da convivência está em compreender como o clima funciona e adequar-se a ele. Não se trata mais de "acabar com a seca", mas de adaptar-se de forma inteligente. É preciso interferir no ambiente, é claro, mas respeitando as leis de um ecossistema que, embora frágil, tem riquezas surpreendentes (MALVEZZI, 2007, p.11-12, grifo nosso).

Para Chacon (2007, p.34), a ideia de convivência representa "um deslocamento paradigmático, da ótica da negação das características ecológicas da região, para um enfoque de aceitação". Em Silva (2007, p.469, 476), é possível apreender como o discurso da convivência com o semiárido associa-se à legitimação de uma ciência (verdade) ecológica, como parte da crítica às práticas sociais consideradas não apropriadas:

A introdução de práticas econômicas e tratos culturais nem sempre adequados aos ecossistemas locais é resultado do processo de ocupação do Semi-árido. As práticas não-apropriadas àquela realidade, com a excessiva exploração dos recursos naturais e a ausência dos estudos de ecologia das regiões naturais, é que levaram os lavradores a insistir nos cultivos dos cereais em ambientes impróprios, desde o período de colonização (SILVA, 2007).

Na sua longa trajetória de pesquisador e engenheiro do Dnocs, por mais de trinta anos, José Guimarães Duque dispôs-se a estudar e interpretar a região, em seus aspectos fundamentais de solo, água e clima. Em seus estudos 
destaca a necessidade de mudança da concepção e da orientação das políticas de combate à seca: 'o conceito de seca era aquele de modificar o ambiente para o homem nele viver melhor. A ecologia está nos ensinando é que nós devemos preparar a população para viver com a semi-aridez, tirar dela as vantagens ${ }^{8}$ (SILVA, 2007).

Harmonização, adequação, adaptação, aceitação, viver com: eis as variações semânticas que informam o processo de construção de significados associados à ideia de convivência. A prevalência de uma dimensão social a ser transformada para se adaptar a uma dimensão ambiental a ser conservada não é elaborada sem problemas. Uma das tarefas a que nos propomos, neste texto, é justamente refletir sobre as contradições presentes na defesa desta noção, ainda que estas contradições não sejam percebidas por aqueles que ativam o conceito nas lutas simbólicas com as quais se envolvem.

É importante analisar, neste momento, o que para muitos é o documento inaugural do paradigma da convivência, a Declaração do Semiárido Brasileiro, divulgada pela Articulação do Semiárido (ASA Brasil) em 1999. Neste texto, há 12 referências ao termo convivência, e nenhuma referência ao termo adaptação. No documento, não se apresenta uma definição explícita do que seria a convivência com o semiárido, mas uma leitura atenta nos ajuda a apreender alguns dos elementos centrais de mobilização de categorias na construção de uma "ideologia que justifica o engajamento" (QUADRO 1).

8 É importante destacar o esforço de Silva (2007) em identificar os precursores da ideia de convivência. Para ele, as obras de Celso Furtado, Josué de Castro e Guimarães Duque são fontes de inspiração deste novo paradigma. Para a influência de Furtado, vide também Nascimento (2008). Não é o caso de resenhar aqui essa paternidade, certamente problemática, mas apenas chamar a atenção para a estratégia de filiar a noção de convivência a autores "canônicos" da reflexão sobre o Nordeste. 


\section{EXCERTOS DA DECLARAÇÃO DO SEMIARIDO BRASILEIRO}

(continua)

\section{Excerto 1.}

A convivência com as condições do semiárido brasileiro e, em particular, com as secas é possível. É o que as experiências pioneiras que lançamos, há mais de dez anos, permitem afirmar hoje.

Excerto 2.

Este programa [de convivência com o semiárido] está fundamentado em duas premissas:

- A conservação, uso sustentável e recomposição ambiental dos recursos naturais do semiárido.

- A quebra do monopólio de acesso a terra, água e outros meios de produção.

O Programa constitui-se, também, de seis pontos principais: conviver com as secas, orientar os investimentos, fortalecer a sociedade, incluir mulheres e jovens, cuidar dos recursos naturais e buscar meios de financiamentos adequados.

Excerto 3.

O semiárido brasileiro caracteriza-se, no aspecto socioeconômico, por milhões de famílias que cultivam a terra, delas ou de terceiros. Para elas, mais da metade do ano é seco e a água tem um valor todo especial. Além disso, as secas são fenômenos naturais periódicos que não podemos combater, mas com os quais podemos conviver.

Excerto 4.

Vale lembrar, também, que o Brasil assinou a Convenção das Nações Unidas de Combate à Desertificação, comprometendo-se a "atacar as causas profundas da desertificação", bem como "integrar as estratégias de erradicação da pobreza nos esforços de combate à desertificação e de mitigação dos efeitos da seca". Partindo dessas reflexões, nosso Programa de Convivência com o Semiárido inclui:

- O fortalecimento da agricultura familiar, como eixo central da estratégia de convivência com o semiárido, em módulos fundiários compatíveis com as condições ambientais. Terminaram por gerar novas pressões, que contribuíram aos processos de desertificação e reforçaram as desigualdades econômicas e sociais.

Por isso, o Programa de Convivência com o Semiárido compreende, entre outras medidas: 
- A descentralização das políticas e dos investimentos, de modo a permitir a interiorização do desenvolvimento, em prol dos municípios do semiárido.

- A priorização de investimentos em infraestrutura social (saúde, educação, saneamento, habitação, lazer), particularmente nos municípios de pequeno porte.

- Maiores investimentos em infraestrutura econômica (transporte, comunicação e energia), de modo a permitir o acesso da região aos mercados.

- Estímulos à instalação de unidades de beneficiamento da produção e empreendimentos não agrícolas.

- A regulação dos investimentos públicos e privados, com base no princípio da harmonização entre eficiência econômica e sustentabilidade ambiental e social.

Excerto 5.

O combate à desertificação e a divulgação de formas de convivência com o semiárido através de campanhas de educação e mobilização ambiental.

QUADRO 1- Excertos da Declaração do Semiárido Brasileiro (ASA Brasil, 1999)

FONTE - Quadro criado pelos autores

Podemos sintetizar algumas ideias relacionadas à noção de convivência com o semiárido presentes no documento divulgado pela ASA Brasil:

a) Conviver com as secas (ou seja, com as condições climáticas e ecológicas da região) (excertos 1, 2 e 3 - QUADRO 1);

b) Conservar e recuperar o ambiente (excertos 2 e 4 - QUADRO 1);

c) Democratizar o acesso a terra e à água (excerto 2 - QUADRO 1);

d) Apoiar à agricultura familiar (excertos 3 e 4 - QUADRO 1);

e) Erradicar a pobreza (excerto 3 - QUADRO 1);

f) Realizar ações localizadas e interiorizadas (excerto 4 QUADRO 1) e

g) Priorizar a educação e mobilização ambiental (excerto 5 QUADRO 1). 
Há, ainda, uma defesa geral presente na declaração da ASA Brasil quanto ao protagonismo da sociedade civil organizada na construção de alternativas aos antigos modelos de desenvolvimento propostos para o Nordeste. Esta ênfase é recuperada em outro documento, intitulado "Declaração da Caatinga", elaborado durante a realização da I Conferência Regional de Desenvolvimento Sustentável do Bioma Caatinga - A caatinga na Rio+20, realizada nos dias 17 e 18 de maio de 2012, com a participação de membros dos governos estaduais, parlamentares, representantes do setor privado, do terceiro setor, dos movimentos sociais, da comunidade acadêmica e de entidades de pesquisa dos Estados de Alagoas, Bahia, Ceará, Minas Gerais, Paraíba, Pernambuco, Piauí, Rio Grande do Norte e Sergipe, realizada em Fortaleza pelo Banco do Nordeste e Instituto Nordeste XXI. Neste texto ${ }^{9}$, há 15 referências à convivência com a seca ou com o semiárido (QUADRO 2).

\section{REFERÊNCIAS A IDEIA DE CONVIVENCIA NA DECLARAÇÃO DA CAATINGA \\ (continua)}

\begin{tabular}{|c|l|}
\hline 1 & $\begin{array}{l}\text { A obtenção de conhecimentos relacionados à convivência } \\
\text { com as condições de semiaridez, numa perspectiva de edu- } \\
\text { cação contextualizada, eleva significativamente a qualidade } \\
\text { de vida nas áreas abrangidas pela Caatinga, principalmente } \\
\text { daquelas populações que moram em comunidades rurais, } \\
\text { representando, inclusive, um vetor de inclusão, ascensão } \\
\text { social e sustentabilidade ambiental. (p. 2) }\end{array}$ \\
\hline 2 & $\begin{array}{l}\text { Promover programas de educação e conscientização pública } \\
\text { que abordem temas relacionados ao bioma Caatinga, espe- } \\
\text { cialmente a conservação da biodiversidade, a convivência } \\
\text { com a seca e a compreensão das causas e efeitos da desertifi- } \\
\text { cação. (p. 3) }\end{array}$ \\
\hline
\end{tabular}

9 A "Declaração da Caatinga" é dividida em duas partes. A primeira apresenta a visão e os compromissos gerais. Na segunda parte, estes compromissos são especificados por estado e instituição. 


\begin{tabular}{|c|l|}
\hline 3 & $\begin{array}{l}\text { Garantia de educação pública de qualidade, contextualizada } \\
\text { para a convivência com o semiárido. (p. 12) }\end{array}$ \\
\hline 4 & $\begin{array}{l}\text { Para o enfrentamento das questões relacionadas às mudanças } \\
\text { climáticas, diversificar a matriz energética, construir estraté- } \\
\text { gias de convivência e adaptação ao semiárido e apoiar a área } \\
\text { de desenvolvimento científico e tecnológico. (p. 17) }\end{array}$ \\
\hline 5 & $\begin{array}{l}\text { Apresentar, ao Governo do Estado, um projeto de Lei de } \\
\text { Política Estadual de Convivência com o Semiárido Cearense, } \\
\text { tendo por base os estudos e documentos do Pacto pelo } \\
\text { Semiárido Cearense, objetivando a articulação e integração } \\
\text { das políticas voltadas para essa região do estado, o desen- } \\
\text { volvimento de novas ações adequadas à convivência com o } \\
\text { semiárido e possibilitando um acompanhamento da sua exe- } \\
\text { cução de forma compartilhada (Ceará). (p.19) }\end{array}$ \\
\hline 6 & $\begin{array}{l}\text { Incorporação, nos planos municipais de educação, de elemen- } \\
\text { tos de discussão de convivência com o semiárido, baseados } \\
\text { na educação contextualizada e ambiental. (p.27) }\end{array}$ \\
\hline 7 & $\begin{array}{l}\text { Produção e difusão de material didático voltado para a educa- } \\
\text { ção no campo e convivência no semiárido. (p. 27) }\end{array}$ \\
\hline 8 & $\begin{array}{l}\text { Assessoria e Capacitação para implementação do Programa } \\
\text { de Formação e Mobilização Social para a convivência com } \\
\text { o semiárido: Um Milhão de Cisternas Rurais, por meio de } \\
\text { capacitação técnica e construção de cisternas para captação } \\
\text { e armazenamento de água de chuva, visando à preservação, } \\
\text { o gerenciamento e ampliação do acesso à água e aos demais } \\
\text { meios de produção e direitos básicos no Semiárido. (p. 31) }\end{array}$ \\
\hline 9 & $\begin{array}{l}\text { Participação no Fórum Piauiense de Convivência com o } \\
\text { Semiárido e ASA-Articulação no Semiárido Brasileiro. (p. 31) }\end{array}$ \\
\hline 10 & $\begin{array}{l}\text { Implantação e construção de tecnologias de captação de água } \\
\text { da chuva para o consumo humano (25 mil cisternas de pla- } \\
\text { cas e 1.00o cursos de capacitação em GRH- Gestão Recursos } \\
\text { Hídricos para as famílias beneficiadas, na perspectiva da con- } \\
\text { vivência com o semiárido). (p. 32) }\end{array}$ \\
\hline
\end{tabular}




\begin{tabular}{|c|l|}
\hline 11 & $\begin{array}{l}\text { Implantação e construção de tecnologias de captação de água } \\
\text { da chuva para a produção de alimentos (10 mil cisternas cal- } \\
\text { çadão e } 500 \text { cursos de Sistema Simplificado de Manejo de } \\
\text { Água para as famílias beneficiadas, na perspectiva da convi- } \\
\text { vência com o semiárido). (p. 32) }\end{array}$ \\
\hline 12 & $\begin{array}{l}\text { Consolidar, no Piauí, a Rede de Educação do Semiárido } \\
\text { Brasileiro - RESAB, implantando uma educação contextuali- } \\
\text { zada, na perspectiva da convivência com o semiárido. (p. 32) }\end{array}$ \\
\hline 13 & $\begin{array}{l}\text { Dar continuidade às ações de educação para a convivência } \\
\text { com o semiárido e às ações de prevenção de danos ambien- } \\
\text { tais. (p. 33) }\end{array}$ \\
\hline 14 & $\begin{array}{l}\text { FPCSA - Fórum Piauiense de Convivência com o Semiárido } \\
\text { (p. 35) }\end{array}$ \\
\hline
\end{tabular}

QUADRO 2- Referências à ideia de convivência na Declaração da Caatinga (2012)

FONTE - Quadro criado pelos autores

Diferente da Declaração do Semiárido, neste novo texto as referências à ideia de adaptação são explícitas. O termo aparece cinco vezes ${ }^{10}$ no contexto de adaptação às mudanças climáticas e de transferência de tecnologias sustentáveis, definidas como "adequadas às necessidades específicas das populações locais, com especial atenção aos efeitos sociais, culturais, econômicos e ambientais" de tais tecnologias. A introdução de uma nova categoria, a de mudanças climáticas, que tem sido bastante enfatizada no debate ambiental dos últimos anos, dota o ambiente também de um caráter mutável, em oposição ao ambiente estável predominante, há poucos anos, no debate sobre a convivência com o semiárido. Assim como acontece com a dimensão social, também em relação à dimensão ambiental, a adesão a um modelo geral conservantista

10 As categorias dominantes mobilizadas no documento ainda são desenvolvimento (83 menções) e sustentável/sustentabilidade (71 menções). Este achado não é incoerente com a tese da convivência como especificação do desenvolvimento sustentável para o semiárido. Ressalte-se que há 13 menções ao termo pobreza e 07 menções à agricultura familiar. 
não deixa de apresentar tensões e contradições, como resultado esperado das convergências de expectativas e interesses de diferentes atores sociais em torno de um mesmo projeto político.

A leitura da "Declaração da Caatinga" permite identificar as categorias que são associadas diretamente ao tema da convivência com o semiárido:

a) Convivência e educação contextualizada;

b) Convivência e populações de comunidades rurais;

c) Convivência, mudança climática e desertificação;

d) Convivência, ciência e tecnologia.

Há uma diferença importante a ser destacada em relação à "Declaração do Semiárido" de 1999, e ela se refere aos efeitos dos esforços de institucionalização da noção de convivência com o semiárido. O desejo de que a ideia de convivência pudesse orientar políticas públicas e a ação estatal está explicitado no documento de 1999. Mas a "Declaração da Caatinga" (2012) revela muito claramente como a institucionalização vai modificando os contextos em que o conceito é agenciado, além de revelar uma enorme multiplicidade de atores sociais que aderiram à ideia de convivência. $O$ documento propõe, entre outras coisas:

Criar a Agenda Positiva para a Caatinga, um plano de comunicação cujo objetivo será intensificar a divulgação das riquezas do patrimônio natural e cultural do bioma, com mudança do foco, atualmente centrado na pobreza, para um paradigma baseado no campo das possibilidades e das belezas existentes (p. 3).

Os compromissos aqui assumidos devem ser contemplados e integrados nas políticas de Estado, como estímulos ao uso eficiente dos recursos naturais, à produção e ao consumo sustentáveis, à cultura, à ciência, tecnologia e inovação, à geração de empregos, à segurança alimentar, à erradicação da pobreza, 
à adaptação às mudanças climáticas e ao combate à desertificação e todos os demais requisitos relevantes ao desenvolvimento sustentável do bioma Caatinga (DECLARAÇÃO DA CAATINGA, 2012, p.6).

São compromissos diferentes daqueles assumidos pela ASA Brasil em sua carta de princípios:
A ASA se fundamenta no compromisso com as necessidades, potencialidades e interesses das populações locais, em especial os agricultores e agricultoras familiares (...) (item 3)
A ASA busca contribuir para a implementa- ção de ações integradas para o semiárido, fortalecendo inserções de natureza política, técnica e organizacional, demandadas das entidades que atuam nos níveis locais; apoia a difusão de métodos, técnicas e procedimen- tos que contribuam para a convivência com o Semiárido (item 4) (ASA BRASIL, [19--]).

A centralidade da ASA Brasil ${ }^{11}$ na formulação do debate sobre a convivência, porém, é ainda inquestionável. Silva (2007) repercute algumas das principais categorias mobilizadas pela Articulação do Semiárido quando diz que a ideia de convivência se refere à valorização do local, da diversidade cultural, da recomposição e afirmação de identidades e territórios; à mudança de percepção sobre a realidade local; à experimentação de alternativas apropriadas de produção; e à construção de novas perspectivas de desenvolvimento junto a populações marcadas pela condição de

11 Há, sem dúvida, problemas em se falar de forma genérica na ASA Brasil. Consideramos aqui a ASA Brasil como porta-voz institucional de certos discursos. Mas não nos foi possível identificar quem fala e de que posição social quando fala a ASA. 
pobreza. Ele então define a convivência com o semiárido como sendo:

Uma perspectiva cultural orientadora da promoção do desenvolvimento sustentável no Semiárido, cuja finalidade é a melhoria das condições de vida e a promoção da cidadania, por meio de iniciativas socioeconômicas e tecnológicas apropriadas, compatíveis com a preservação e renovação dos recursos naturais. (SILVA, 2006, p. 272).

É chegado o momento de responder, pelo menos inicialmente, por que o paradigma de convivência com o semiárido conforma uma perspectiva conservantista ou, em outros termos, um conservadorismo de vanguarda. Por conservantismo, queremos significar uma tendência a privilegiar a manutenção (no lugar da transformação) de modos de vida e de relação com a natureza. Num sentido mais ampliado, também se refere ao desejo de conservar modos de vida junto com a proteção da natureza ${ }^{12}$. E eis que se revela a contradição central do paradigma da convivência: instaurar um novo padrão civilizatório ou garantir a continuidade de um padrão civilizatório ameaçado pelas forças modernizadoras? A compreensão da convivência como adaptação é o núcleo central das tendências conservantistas deste modelo. E a busca por melhoria das condições de vida das populações rurais do semiárido informa o caráter transformador do paradigma.

O texto a seguir, encontrado em Chacon (2007, p.38), exemplifica bem o poder do discurso conservantista:

Os mecanismos de relações sociais não são apenas ignorados; são destruídos. A eletrificação rural, por exemplo, promove a

12 Uma perspectiva conservantista, assim, não é adotada apenas pelos defensores da convivência com o semiárido, sendo padrão ideológico dominante, por exemplo, no debate sobre as chamadas "populações tradicionais", em que as mesmas tensões entre políticas que mudem a vida das pessoas sejam articuladas em meio a um discurso de valorização dos modos de vida existentes, a serem preservados. 
massificação de uma propaganda consumista que leva ao sertanejo um sentimento de inutilidade, promovendo o deslocamento deste para os meios urbanos à procura não só de ocupação, mas principalmente de significação e pertencimento a esse novo padrão levado até por diversos instrumentos da modernização, como as antenas parabólicas. O sentimento de pertencer ao sertão não apenas desaparece, mas é verdadeiramente extirpado, visto que é traduzido como atraso. Essa destruição do nexo das relações sociais afeta não apenas as pessoas, mas toda uma teia de atitudes e processos que norteiam a cultura sertaneja, inclusive no que se refere à relação do Homem com a Natureza. Em termos culturais, os impactos de tal transformação só serão percebidos em profundidade no longo prazo, embora já haja sintomas claros de mudança. Especialmente em relação ao meio ambiente, os novos paradigmas (inclusive de produção agrícola) afetam a forma como este é visto pelo sertanejo, destruindo laços históricos e culturais que por séculos comandaram a vida no Sertão. Toda uma tradição no manejo da biodiversidade desse espaço especial é aos poucos esquecida pelo povo do lugar, usurpado em seus modos e atitudes, levado a acreditar que sua organização social e produtiva é "ultrapassada", e que o que é bom é o que está fora dali, ou seja, o modelo urbano de produção e consumo. Parece-lhes só restarem duas opções: partir em busca da inserção nesse modelo, ou tentar reproduzi-lo em seu espaço, negando sua cultura e suas tradições. De uma forma ou de outra negam suas possibilidades e as do seu espaço, convencidos de que ali já não é mais 
possível viver respeitando o que aprenderam com o tempo. Assim, vão apagando suas lembranças (CHACON, 2007, p.38)

O paradigma da convivência com o semiárido é, ao final, uma crítica à modernização, uma defesa das relações sociais tradicionais e de um novo padrão de relação com a natureza. Ou seria um modelo de modernização para populações das áreas rurais nordestinas? Macedo (2004) defende a ideia de que as políticas de convivência conformam uma territorialidade ambígua, operada por um imaginário local e globalizado.

\section{Educação para a convivência: ênfase na mobilização ideológica}

Um aspecto a ser ressaltado nas formulações acerca do paradigma da convivência com o semiárido é a ênfase sobre os processos de educação, treinamento, capacitação, em cursos especiais, através da educação do campo ou como conteúdo nos processos de educação formal (PINTO; LIMA, 2005). O discurso, neste ponto, assume uma de suas mais claras contradições. De um lado, assume-se que há um saber desenvolvido ao longo do tempo pelas populações rurais da região que possibilita a convivência com as condições ambientais do semiárido, mas, de outro, defende-se que é preciso preparar a população para a convivência.

Esta contradição é exemplificada (e de certo modo superada discursivamente) em Silva (2007, p.476), quando afirma que a

valorização do espaço territorial para convivência requer, portanto, novas formas de pensar, sentir e agir no ambiente no qual se está inserido. Nessa perspectiva cultural, a convivência é um reaprendizado da comunhão intrínseca entre os sujeitos e a realidade do Semiárido através das experiências vividas (SILVA, 2007, p.476).

Eis então a fórmula para superar esta tensão: a formação para convivência seria um reaprendizado, a recuperação de um saber 
tradicional negado pelos esforços de modernização que marcam os "velhos" paradigmas de desenvolvimento do Nordeste.

Sem uma análise detalhada dos múltiplos programas de formação para a convivência com o semiárido não é possível apreender quais os modelos dominantes que estão sendo utilizados nas ações empreendidas por diferentes atores sociais. Esta análise não será realizada neste capítulo. Mas Pinto e Lima (2005, p.2) oferecem indicações sobre estes conteúdos na experiência que descrevem ao afirmarem que "a concepção do programa é a de que ao se aprofundar o conhecimento sobre o clima da região, os pequenos agricultores poderão minimizar os efeitos negativos que diminuem as suas potencialidades, particularmente de uso do solo". Ou seja, um programa de "difusão" do conhecimento científico, já que se supõe que o conhecimento tradicional sobre o clima da região já é de domínio destas populações. Não se detalha, porém, em que medida este conhecimento científico do clima operaria a potencialização dos sistemas produtivos destes agricultores.

É comum à literatura sobre a convivência, principalmente aquela dedicada a relatos de experiências, o recurso às narrativas exemplares, em que é dada voz aos agricultores e agricultoras para que relatem suas vivências com a adoção desta nova perspectiva em suas práticas produtivas. Trata-se de um mecanismo de argumentação em que a legitimidade do modelo associa-se à sua eficácia transformadora. Escolhemos uma destas narrativas exemplares, oferecidas pelo trabalho de Pinto e Lima (2005), colhida entre agricultores familiares da mesorregião Nordeste Baiano (QUADRO 3).

A análise desta narrativa aponta alguns elementos comuns ao que seria o processo de adesão ideológica e prática ao paradigma da convivência:

a) O confronto entre alternativas tradicionais (migrar), que são também modernas, na medida em que se conformam ao padrão dominante de desenvolvimento, e a possibilidade de inserir-se num novo modelo produtivo e de relação com natureza; 
b) A participação em alguma "experiência" de convivência com o semiárido, associada normalmente a algum tipo de formação ou processo educativo, que tem caráter revelador de novas possibilidades de vida e trabalho;

c) A menção a práticas específicas que são associadas a esta nova forma de viver e produzir, no caso o uso do mandacaru, planta nativa da caatinga, como alternativa de alimentação animal, em substituição as fontes energéticas exógenas ou modernas, que criariam dependência e degradação ambiental.

\section{NARRATIVA EXEMPLAR DA EXPERIENCIA DE UM AGRICULTOR COM A IDEIA DE CONVIVENCIA} (continua)

Outro exemplo, também de um pequeno agricultor que desesperado com a miséria em que vivia e acreditando que poderia viver melhor na cidade de São Paulo, porque já tinha parentes trabalhando por lá, estava decidido a ir embora. Mas, depois de participar do Programa de Convivência com o Semiárido, desistiu dessa viagem.

Esse pequeno produtor, hoje com cinquenta anos de idade, é nascido e criado na região Semiárida brasileira e sempre conviveu com atividades voltadas para a roça, plantando basicamente milho, feijão e mandioca e utilizando práticas seculares transmitidas através de gerações: pais, avós, etc. A falta de conhecimento sobre a diversidade de condições no Semiárido levou esse pequeno produtor e seus familiares a exaurirem a terra onde viviam e, consequentemente, a considerarem a roça como uma atividade negativa.

Mesmo com a ideia de ir tentar a vida em outro lugar, ele aceitou participar do Programa, fazendo o curso de capacitação. E o que para ele seria apenas mais uma conversa, levou-o a abandonar definitivamente o projeto de ir embora, como se confirma em seu depoimento: 
Nesses quinze dias, a gente descobriu o que a gente precisava descobrir, o segredo da coisa de como viver aqui no Nordeste. Porque lá foi reforçada todas as informações de convivência com a seca, como trabalhar a questão da roça, do animal, da água e quais são as necessidades e a quantidade também. E a gente foi vendo aquelas coisas, e eu fui me preocupando com isso. E eu voltei para cá com aquela vontade mesmo de praticar (Agricultor anônimo - informação verbal).

Para o pequeno produtor, o conhecimento sobre o ciclo da água, da necessidade de saber qual o consumo diário; de como trabalhar o solo; produzir e armazenar forragem e de observar as plantas e os animais foi fundamental para que ele tivesse uma nova visão sobre o lugar onde vivia.

A partir do conhecimento adquirido na capacitação, o pequeno produtor desenvolveu uma experiência a que chamou de pesquisa. Ou seja, observando o comportamento das cabras ao se alimentarem, ele percebeu que elas ao comerem mandacaru (Cereus jamacaru), apresentavam um aspecto melhor, ganhavam mais peso e aumentavam a produção de leite. E concluiu:

O mandacaru é uma planta da caatinga; então, porque não plantar o mandacaru? Então eu fui ver como podia mexer com isso. A gente fez uma pesquisa entre os animais para descobrir a quantidade que era necessária para o animal ficar bem alimentado (PINTO ; LIMA, 2005, p. 9-10).

QUADRO 3 - Narrativa exemplar da experiência de um agricultor com a ideia de convivência

FONTE - Quadro criado pelos autores

As narrativas legitimam não apenas o paradigma da convivência, mas também as ações daqueles que mobilizam recursos humanos e financeiros em projetos e programas realizados em 
diferentes estados do Nordeste. Estas ações estariam comprometidas com o que Carvalho e Egler (2003) chamam de "processo permanente de aprendizagem" da população sertaneja, que tendo sido iniciado há muito tempo, é reforçado pela educação para a convivência. E a continuidade do aprendizado e da promoção da convivência:

Requer instrução e educação para todos, por métodos formais (para os mais jovens) e processos menos ortodoxos (para os de mais idade). Exige mudança de mentalidade dos beneficiários diretos dos processos de inovações, dedicação dos que vierem a ser responsáveis por essas mudanças e muito compromisso social das elites dirigentes e formadores de opinião (CARVALHO; EGLER, 2003, p.164).

Aziz Ab'Sáber (2003) considera uma falácia “ensinar o nordestino a conviver com a seca", coerente, portanto, com a ideia de que os nordestinos já desenvolveram, ao longo dos anos, práticas adaptadas aos limites impostos pelo ecossistema em que vivem, mas:

(...) mesmo perfeitamente adaptados à convivência com a rusticidade permanente do clima, os trabalhadores das caatingas não podem conviver com a miséria, o desemprego aviltante, a ronda da fome e o drama familiar profundo criado pelas secas prolongadas (AB'SÁBER, 2003, p.85).

Nascimento (2008, p. 2) oferece o que nos parece ser um diagnóstico válido para compreensão dos desafios envolvidos com a adoção do paradigma da convivência:

A noção de Convivência com o Semiárido não é somente a resposta a uma característica peculiar das áreas semiáridas nordestinas, a estiagem, ela incorpora modos e técnicas de 
saber-fazer capitaneadas por governos, organizações e atores locais que refletem contextos sócio-espaciais específicos e interesses em disputa em torno da questão do desenvolvimento (NASCIMENTO, 2008, p.2, grifos do autor).

Temos, então, duas direções nos esforços de mobilização ideológica envolvidos com a adesão ao paradigma da convivência. A primeira direção se refere ao convencimento de governos, organizações e atores locais a assumirem os princípios deste paradigma, tarefa que é realizada tanto pela produção de literatura sobre o tema como em ações diretas na tentativa de influenciar políticas e conseguir financiamentos para projetos, bem exemplificadas pelas iniciativas realizadas junto ao Conselho Nacional de Segurança Alimentar e Nutricional, que abrem este capítulo. A segunda direção, que tentamos delinear nesta seção, refere-se aos cursos e outros mecanismos de formação para a convivência com o semiárido oferecidos aos agricultores familiares e outros atores sociais envolvidos com a temática do desenvolvimento, governamentais e não governamentais, nos municípios do interior do Nordeste. No primeiro caso, trata-se da opção pela institucionalização do paradigma. No segundo, a construção de sua legitimidade junto àqueles que seriam beneficiados por sua adoção. Nas duas situações, são engendradas práticas discursivas que produzam engajamento efetivo ao modelo.

\section{Mundo Rural e agricultores familiares como alvo das políticas de convivência}

A formulação de um discurso da convivência com o semiárido esteve sempre associada a ações concretas que pudessem demonstrar as vantagens do novo paradigma. Estas ações ainda estão associadas prioritariamente à atuação de organizações não governamentais, com destaque para aquelas que formam a Articulação do Semiárido Brasileiro. Nos últimos anos, porém, este discurso tem sido ativado também em programas e ações de organizações

governamentais (SILVA, 2007; PINTO; LIMA, 2005). Nascimento 
(2008, p.13) é enfático ao ressaltar a colaboração entre organizações governamentais e não governamentais neste processo:

A noção de Convivência com o Semiárido tornou-se um modelo operacional importante nas políticas públicas regionais, enfatizando as condições técnicas e de produção apropriadas espacialmente pela sociedade. Constata-se que muitas das experiências (...) não devem ser encaradas mais como auto-suficientes, nem deixar que sigam trajetórias erráticas em função da ausência de planejamento público propriamente dito, o que torna imprescindível tratá-las de forma mais abrangentes do ponto de vista socioespacial. (...) [As experiências conduzidas por organizações da sociedade civil] mesmo que pontuais, por já terem um certo acúmulo e algum nível de abrangência espacial, podem ser capazes de nortear estratégias de desenvolvimento rural para o semiárido baiano e nordestino (NASCIMENTO, 2008, p.13).

O QUADRO 4 traz alguns exemplos de ações/programas em que o discurso da convivência com o semiárido é articulado. Seus proponentes são duas organizações da sociedade civil (ASA Brasil e Federação da Agricultura e Pecuária do Estado da Bahia - FAEB/ SENAR) ${ }^{13}$ e duas governamentais, sendo uma federal (Banco do Nordeste) e outra estadual (Secretaria de Desenvolvimento Agrário do Estado do Ceará - SDA/CE). Em comum, estas ações são voltadas para agricultores familiares, informando que o paradigma da convivência é basicamente um modelo para uma parcela da população rural, já que não temos conhecimento de ações pensadas para o ambiente urbano, nem tem entrado na agenda a formulação de

13 Podemos citar ainda as ações de outras organizações não governamentais como IRPAA, SERTA, Caatinga e Cáritas Brasileira, com muitos projetos no tema da convivência. 
políticas para os grandes proprietários rurais. Mas há também especificidades importantes.

\section{EXEMPLOS DE POLITICAS/AÇÕES DE CONVIVENCIA COM O SEMIARIDO \\ (continua)}

\begin{tabular}{|l|l|l|}
\hline Proponente & \multicolumn{1}{|c|}{ Linha de ação } & \multicolumn{1}{|c|}{ Contexto/objeto } \\
\hline ASA Brasil & $\begin{array}{l}\text { Programa de Formação } \\
\text { e Mobilização Social } \\
\text { para Convivência com o } \\
\text { Semiárido }\end{array}$ & $\begin{array}{l}\text { Programa Uma Terra e Duas } \\
\text { Águas (P1+2) } \\
\text { Programa Um Milhão de } \\
\text { Cisternas (P1MC) } \\
\text { Ações desenvolvidas em } \\
\text { vários estados nordestinos. }\end{array}$ \\
\hline BNB & $\begin{array}{l}\text { Incentivo à utilização de tec- } \\
\text { nologia de convivência com } \\
\text { a seca }\end{array}$ & $\begin{array}{l}\text { Elaborada no âmbito das } \\
\text { diretrizes da política do } \\
\text { banco de apoio à agricultura } \\
\text { familiar. }\end{array}$ \\
\hline $\begin{array}{l}\text { Federação da } \\
\text { Agricultura } \\
\text { e Pecuária } \\
\text { do Estado } \\
\text { da Bahia } \\
\text { - FAEB/ } \\
\text { SENAR }\end{array}$ & $\begin{array}{l}\text { Programa "Viver Bem no } \\
\text { Semiárido" } \\
\text { (lançado em 2012) }\end{array}$ & $\begin{array}{l}\text { Com o propósito de se tornar } \\
\text { "a maior ação de convivência } \\
\text { com a seca já feita na Bahia", } \\
\text { objetiva atuar em proprie- } \\
\text { dades rurais que sejam } \\
\text { disseminadoras e multiplica- } \\
\text { doras de ações e tecnologias } \\
\text { de convivência. Na primeira } \\
\text { fase, vai atender 220 pro- } \\
\text { priedades em 11 municípios. }\end{array}$ \\
\hline
\end{tabular}




\begin{tabular}{|c|c|c|}
\hline $\begin{array}{l}\text { Secretaria de } \\
\text { Desenvol } \\
\text { vimento } \\
\text { Agrário do } \\
\text { Estado do } \\
\text { Ceará }\end{array}$ & $\begin{array}{l}\text { Projetos de práticas agrí- } \\
\text { colas de convivência com o } \\
\text { semiárido }\end{array}$ & $\begin{array}{l}\text { Objetiva fortalecer a agricul- } \\
\text { tura no semiárido. } \\
\text { Exemplos de projetos: } \\
\text { a) reforma e moderniza- } \\
\text { ção das casas de farinha em } \\
\text { seis municípios: Milagres, } \\
\text { Redenção, Crato, Ararendá, } \\
\text { Itarema e Ocara; } \\
\text { b) entrega de } 43 \text { kits de } \\
\text { medidores horo-sazonal } \\
\text { às famílias de pequenos } \\
\text { produtores/irrigantes. } \\
\text { equipamento garantiria a } \\
\text { redução na conta de energia } \\
\text { elétrica em até } 73 \% \text {; } \\
\text { c) implantação de práti- } \\
\text { cas agrícolas mecânicas } \\
\text { e edáficas vegetativas e } \\
\text { agroecológicas para o arma- } \\
\text { zenamento de água no solo; } \\
\text { d) implantação de minifá- } \\
\text { bricas de biocompostagem } \\
\text { orgânica, junto com cinco } \\
\text { associações de produtores - } \\
\text { localizadas nos municípios } \\
\text { de Carnaubal, Santa Quitéria, } \\
\text { Jaguaretama, Icó e Itapajé } \\
\text { - para a produção do com- } \\
\text { posto orgânico do Biodiesel } \\
\text { (mamona e girassol). }\end{array}$ \\
\hline
\end{tabular}

QUADRO 4 - Exemplos de políticas/ações de convivência com o semiárido

FONTE - Quadro criado pelos autores

A ASA Brasil e a FAEB - em que pesem suas diferenças de origem, sendo uma organização representativa dos movimentos sociais e outra da classe patronal - apostam em tecnologias apropriadas, também chamadas de tecnologias sociais. Neste campo, 
o programa de instalação de cisternas da ASA é paradigmático, e copiado por diferentes órgãos públicos. Também prevalece, nas ações destas organizações, o compromisso com o efeito demonstrativo das experiências, para que as novas práticas de convivência possam ser difundidas por seu caráter exemplar e bem sucedido de transformação dos sistemas produtivos e da vida dos agricultores ${ }^{14}$.

Já as ações dos órgãos governamentais lançam alguma luz sobre as formas de institucionalização do novo paradigma. No BNB, oferece-se crédito aos agricultores para que financiem "obras hídricas de convivência com a seca, projetos de irrigação, melhorias de pastagens, entre outros investimentos para minimizar os diversos problemas que a seca vem causando na zona rural dos municípios". Uma linha de crédito emergencial foi aberta, em 2012, em virtude da seca, a pedido dos Ministérios do Desenvolvimento Agrário e da Integração Nacional. Se a ideia da convivência é ativada pelo banco quando trata de agricultores familiares (mesmo sem propor ações diferentes das que já eram realizadas), o discurso dominante nas demais ações da instituição se estrutura em torno das noções de desenvolvimento sustentável e modernização. Desenvolvimento e modernização também são a tônica no DNOCS, que anuncia explicitamente - em sua página na internet - a missão de modernizar os instrumentos de combate ao flagelo da seca ${ }^{15}$. No site da SUDENE, a ênfase maior é dada à noção de desenvolvimento sustentável, com destaque menor para o papel a ser desempenhado na modernização das infraestruturas social e econômica.

O exemplo oferecido pelas ações da SDA/CE enquadra-se no modelo dominante de intervenção com vistas à promoção do desenvolvimento em comunidades rurais adotado nas últimas décadas no Nordeste: modernização de casas de farinha; irrigação; armazenamento de água e implantação de pequenas plantas agroindustriais.

14 O Projeto Dom Helder Câmara, do Ministério do Desenvolvimento Agrário, se aproxima, em sua concepção e execução, dos princípios adotados pela ASA Brasil em seus programas.

15 O DNOCS, curiosamente, lançou uma revista institucional intitulada "Conviver". Pomponet (2009) faz a crítica das ações do DNOCS sob o crivo da noção de convivência com o semiárido. 
A SDA/CE negociou ainda com a CHESF "um projeto para formação de pastagem para reserva alimentar e convivência com o Semiárido". As ações governamentais - e é importante ressaltar aqui como os técnicos dos órgãos públicos traduzem o paradigma da convivência - parecem informar muito mais a resiliência de certos modelos de intervenção técnica do que a emergência de um novo paradigma civilizatório. Mas não se deve deixar de enfatizar que não é difícil realizar a tradução destas práticas na nova linguagem das tecnologias apropriadas. Em comum, todas as políticas analisadas parecem indicar a opção por alternativas pontuais, que não buscam promover alterações radicais nos modos de vida das populações atendidas.

\section{Considerações Finais}

Neste texto, não nos colocamos como objetivo avaliar a eficácia da aplicação do paradigma da convivência com o semiárido ou das políticas influenciadas ou inspiradas por ele. Isso não quer dizer, porém, que não estejamos preocupados em apreender algumas das consequências de sua adoção cada vez mais generalizada. E uma das consequências mais inquietantes, do ponto de vista da crítica informada sociologicamente, é a formulação de um discurso que objetiva informar políticas de desenvolvimento fundadas no que temos chamado de "excepcionalismo dos pobres".

O excepcionalismo não é uma novidade na história das sociedades humanas, sendo em alguns momentos ativado para privilegiar grupos sociais dominantes e, em outros, para compensar grupos sociais dominados. É importante, porém, apreender como princípios excepcionalistas são mobilizados. Há pelo menos duas alternativas opostas: como meio de integrar grupos marginalizados ou como instrumento de reforço de suas especificidades. A defesa do paradigma da convivência - até onde podemos enxergar - opta por esta última alternativa.

Partindo da excepcionalidade climática e culminando na defesa de uma excepcionalidade cultural, objetivada em conhecimentos e práticas produtivas adaptadas a certos constrangimentos impostos pela natureza, os defensores do paradigma da convivência acabam 
por assumir o pressuposto que as populações rurais - pobres e marginalizadas - das áreas rurais do interior do Nordeste devem ser objeto de um modelo de desenvolvimento que lhes seja próprio. As políticas a serem formuladas para estas áreas devem ser informadas por tecnologias apropriadas. O exemplo das cisternas de placas é, neste sentido, paradigmático. As cisternas não são anunciadas como alternativas paliativas enquanto não é possível oferecer para os moradores das comunidades rurais do interior do Nordeste água tratada e encanada. Elas simbolizam a capacidade de adaptação do sertanejo, sua criatividade e, por fim, o desejo de que mantenham sua excepcionalidade ${ }^{16}$.

É a partir da operação de pressupostos excepcionalistas que podemos compreender porque as políticas de convivência com o semiárido informam, principalmente, uma estratégia de ação voltada para uma parcela da população que objetiva mantê-los como um grupo diferenciado.

Sendo uma crítica aos padrões dominantes de modernização produtiva e social, com forte preocupação ambiental, o paradigma da convivência com o semiárido não deixa de ser também uma proposta de modernização. Objetiva transformar as condições de vida e de produção dos agricultores familiares do interior do Nordeste e, para isso, opera com diferentes mecanismos dos processos de modernização, e aqui destacamos a questão da mudança técnica e da educação como vetores de transformações sociais. Um projeto de modernização que não é reconhecido como tal e que se instaura sob a tensão do que chamamos de conservadorismo de vanguarda, em que objetivos conservantistas pautam as escolhas entre alternativas de engajamento.

Por que este novo paradigma, conservantista e excepcionalista, consegue tão ampla adesão entre diferentes setores sociais? Limitar-nos-emos, neste ponto, a indicar algumas pistas para reflexão. Um primeiro ponto a ser destacado é que a ideia de convivência, assim como a de desenvolvimento sustentável, é de fácil

16 Não nos deteremos aqui a investigar as fontes desta perspectiva excepcionalista, ainda que esta seja uma tarefa importante. Por enquanto, limitamo-nos a defender sua existência. 
tradução, principalmente quando é apresentada como um padrão normativo geral; como um compromisso não especificado. Cada ator social tem assim a possibilidade de traduzir a noção de convivência a partir das próprias experiências e visões de mundo. Outro ponto que nos parece importante é o esgotamento do discurso do combate à seca, num ambiente social marcado pela crítica contundente dos resultados alcançados pelas políticas de desenvolvimento regional e setorial e ao mesmo tempo motivado pela possibilidade de construir novos modelos. Há que se ressaltar também a eficiente mobilização ideológica operada por alguns atores sociais importantes, particularmente algumas organizações não governamentais ligadas a ASA Brasil, com recursos humanos e financeiros para levar a cabo tal empreendimento no quadro das lutas simbólicas. Finalmente, sendo uma crítica à modernização que não recusa alguns pontos centrais do projeto de modernização, com sua lógica técnico-científica e seu discurso de transformação social de caráter conservantista, o paradigma da convivência pode ser aceito mesmo por setores que não compartilham suas implicações mais radicais.

Nosso objetivo, neste texto, é preciso que se afirme claramente, não foi defender a irrelevância das experiências pautadas na ideia de convivência com o semiárido. Muito ao contrário, toma-se como ponto de partida sua enorme capacidade de mobilizar diferentes atores sociais, constituindo-se assim importante objeto de reflexão. Tentamos trazer, à tona, apenas algumas das implicações dos pressupostos deste paradigma - que merecem uma maior reflexão por parte daqueles envolvidos com sua implementação - e também das formas pelas quais se tem institucionalizado. Ao final, perguntamos: o melhor para os agricultores familiares do semiárido nordestino é um projeto de desenvolvimento pautado no conservantismo e no excepcionalismo, que informa um programa de modernização para os pobres? 


\section{Referências}

AB'SÁBER, A. Os domínios de natureza no Brasil: potencialidades paisagísticas. São Paulo: Ateliê Editorial, 2003.

BOLTANSKI, L. ; CHIAPELLO, E. O novo espírito do capitalismo. São Paulo: Editora WMF Martins Fontes, 2009.

BURAWOY, M. O marxismo encontra Bourdieu. Campinas, SP: Editora da Unicamp, 2010.

CARVALHO, J. O. ; EGLER, C. A. G. Alternativas de desenvolvimento para o Nordeste semi-árido. Fortaleza: BNB, 2003.

CHACON, S. S. O sertanejo e o caminho das águas: políticas públicas, modernidade e sustentabilidade no semi-árido. Fortaleza: BNB, 2007.

GUIMARÃES FILHO, C. ; LOPES, P. R. C. Subsídios para a formulação de um programa de convivência com a seca no semi-árido brasileiro. Petrolina: Embrapa Semiárido, 2001.

MACEDO, O. R. B. A convivência com o semi-árido: desenvolvimento regional e configuração do local no projeto do IRPAA. (Dissertação de Mestrado defendida no PPGS da UFPE), 2004.

MALVEZZI, R. Semi-árido: uma visão holística. Brasília: Confea, 2007.

NASCIMENTO, H. M. A convivência com o semiárido e as transformações socioprodutivas na região do Sisal/Bahia: por uma perspectiva territorial do desenvolvimento rural. Rio Branco, AC: 46 2008. (Congresso da SOBER).

PACHECO, M. E. L. [Carta] 11 jul. 2012, Brasília, DF [para] Rousseff, D., Brasília, DF. $10 \mathrm{f}$. (Faz proposições relativas às estratégias de 
convivência com o Semiárido e os impactos da seca na segurança alimentar e nutricional).

PINTO, E. B. ; LIMA, M. J. A. O programa de convivência com o semiárido brasileiro e sua influência na mudança de hábitos e valores. Puebla, México, 2005. (II Congreso Iberoamericano sobre Desarrollo y Médio Ambiente).

POMPONET, A. S. 100 anos de DNOCS: marchas e contramarchas da convivência com as secas. Porto Alegre: 47, 2009 (Congresso da SOBER).

PRAGANA, V. (2012) Documento do Consea respalda ação da ASA pela convivência com o Semiárido. Disponível em <http://www.asabrasil.org.br/Includes/VersaoImpressao.asp? COD_ NOTICIA=7413> Data de acesso: 08 set. 2012.

SILVA, R. M. A. Entre o combate à seca e a convivência com o semi-árido: transições paradigmáticas e sustentabilidade do desenvolvimento. Brasília, 2006. (Tese de Doutorado, UnB) (mimeo).

SILVA, R. M. A. (2007). Entre o combate à seca e a convivência com o semiárido: políticas públicas e transição paradigmática. Revista Econômica do Nordeste, v. 38 (03): 466-485p.

SUASSUNA, J. (2002) Semiárido: proposta de convivência com a seca. Disponível em <http://www.fundaj.gov.br/index.php?option=com_ content\&view=article\&id=659\&Itemid=376>. Data de acesso: 31 ago. 2012.

WOHLWILL, J. F. Human adaptation to levels of environmental stimulation. Human Ecology, v. 2 (02); 127-147p., 1973. 


\section{Sites Consultados}

www.bnb.gov.br

www.dnocs.org.br

www.sudene.org.br

www.asabrasil.org.br

www.fundaj.gov.br

www.insa.gov.br

www.faeb.org.br

www.cpatsa.embrapa.br

www.fetraece.org.br

www.sda.ce.gov.br

www.projetodomhelder.gov.br

www.caatinga.org.br

www.cpatsa.embrapa.br

www.caritasne2.org.br

www.irpaa.org

www.escolasdereferencia.blogspot.com.br 


\title{
II
}

\section{Quadros Institucionais para a reprodução do Campesinato na Transamazônica}

\author{
Alcione Sousa de Meneses ${ }^{17}$
}

Neste artigo, analiso ações públicas e coletivas que vieram a produzir convergências de investimentos propiciadores da construção de quadros institucionais, todavia pautados na correspondente dotação de agentes sociais constituídos para garantir competências capazes de projetar recursos e serviços elaborados segundo percepção de mundo valorativa da posição de agricultores familiares. Pauto-me no estudo de investimentos políticos de colonos agricultores na região caracterizada como frente pioneira e genericamente definida como Transamazônica, no Sudoeste do Pará.

A viabilidade de constituição da condição social camponesa na região Transamazônica correspondeu à conjugação da intervenção do Estado e da ação coletiva de agricultores. Inicialmente por intermédio do projeto de colonização agrícola do Governo Federal; e depois pela adesão de agricultores que, no processo de sua própria instalação e reprodução, vieram a constituir, por ação mediadora, aparatos institucionais que minimizassem as dificuldades enfrentadas no cotidiano, mas que principalmente permitisse a projeção da vida social desejada, tal como esteve referenciada às respostas

17 Mestra em Ciências Sociais, Professora da Universidade Federal do Pará (UFPA), Campus de Altamira. alcione@ufpa.br 
coletivamente organizadas para responderem aos apelos de recrutamento circulados pelo governo federal.

Esse processo de criação de espaço social, para efeito deste artigo, revela os meandros da construção da trajetória de configuração daquela forma camponesa, portanto, perpassada por estratégias que conformam um campesinato construído segundo ideários específicos, elaborados em quadros institucionais que assentavam projetos oficiais de desenvolvimento. Mas não só: foram também se construindo segundo ideários diversos que, no apelo ao encontro de objetivos comuns, aqueles agricultores vieram a elaborar para si uma outra posição, outro ideário, em grande parte contraposto àquele que lhes foi apresentado. Nesses termos, a Transamazônica fora construída ou foi sendo apropriada como espaço territorializado, associado a formas de pertencimentos e a demandas voltadas para a construção da visibilidade social e política desses agricultores. Dentre elas, aqui destaco os investimentos na profissionalização e os procedimentos de legitimação do projeto político, ambos pautados na ambientalização de projetos de desenvolvimento e de práticas produtivas.

\section{A Transamazônica dos Colonos}

O processo de criação do espaço social legítimo e legitimador dos projetos coletivamente elaborados por colonos agricultores, isto é, que adotaram a forma camponesa, tal como configurada na chamada região Transamazônica, mais particularmente, na microrregião de Altamira/Sudoeste do Pará, distingue-se pelos investimentos na construção de quadros institucionais projetados para modelizar a prática do Estado segundo interesses imediatos e reprodutivos dos próprios agricultores.

Esses investimentos se iniciaram associadamente às ações públicas que fundamentaram a abertura da fronteira agrícola na Amazônia, na década de 1970, mediante a construção da BR-230 a Transamazônica. Esta ação governamental foi complementada pela colocação em prática do projeto de colonização agrícola denominado Programa de Integração Nacional/PIN. 
Ao precário quadro institucional apresentado pelo Estado para colocar em prática esse projeto, os agricultores reagiram investindo em dotação de sentidos legítimos, calcados em suas experiências, desejos coletivos e projeção para inserção diferenciada de familiares. Ao lado do enfrentamento das condições adversas de produção e reprodução das famílias de agricultores, principalmente com a gradativa retirada da ação pública da então frente pioneira, diga-se de imediato, confirmando a inviabilidade socioeconômica daquelas políticas governamentais, os agricultores responderam com a produção de sentidos e ações diferenciadas para aquele projeto político.

Se a construção da Transamazônica e o prosseguimento do projeto de colonização foram abandonados pela ação pública, por descaso com os agricultores e seus familiares, assim lançados ao Deus dará, tal não correspondeu à perspectiva de tais agentes. Muitos deles, considerando a inviabilidade do retorno à região de origem ou do abandono de tantos sacrifícios, associados muitas vezes à descapitalização e ao empobrecimento, decidiram por reordenar o destino social fadado ao descaso e insucesso.

Neste texto, considero exatamente uma dessas reações dos agricultores, qual seja a luta para tornar realidade a construção de um espaço de produção e reprodução sociais. A análise centrada na compreensão de trajetórias constitutivas desse espaço social é aqui assumida como recurso metodológico fundamental: para pensar como as formas organizativas institucionalizadas correspondem à emergência da condição camponesa naquela região, quanto o seu gradativo reconhecimento em disputas concorrenciais. Para tanto, analiso as trajetórias em conformidade com as diversas posições sociais em que tais atores investiram, mas privilegiando dois momentos. O primeiro deles corresponde à constituição de quadros institucionais em conformidade com a imposição do projeto de colonização pelo Estado, contracenada pela gradativa organização coletiva de base comunitário-religiosa, configurada segundo a construção de representações coletivas em torno de um nós, de existência qualificada como real, por ser resposta à mobilização social e por alimentar os investimentos em novas mobilizações. 0 
segundo momento se distingue por ter se constituído tendo por base o sindicalismo rural. Caracterizou-se, portanto, pela consolidação desses quadros institucionais na barganha política por direitos da categoria socioeconômica. Trata-se, portanto, de dois movimentos que se efetivam reciprocamente: ações e projetos reivindicatórios de formas de inclusão na ação pública e, consequentemente, de modificação da mesma a fim de adequá-la aos interesses dos agricultores locais.

O espaço de formulação de projetos e demandas unificou e viabilizou desdobramentos porque se fez, sobretudo, pela constituição do Movimento pela Sobrevivência na Transamazônica (MPST). Deste movimento social mais amplo, outros desdobramentos e ações complementares emergiram tais como a criação da Fundação Viver, Produzir e Preservar (FVPP), que incorpora demandas socioambientais; e a escola Casa Familiar Rural (CFR), instituição pedagógica destinada à formação de mediadores pelo próprio campesinato. Portanto, espaços institucionais portadores de métodos e procedimentos capazes de reproduzir o sistema de crenças e visões de mundo de agricultores, constituídos na contraposição à pecuarização da agricultura e pela incorporação da ambientalização de projetos e práticas produtivas, nesse caso, enquanto referências fundamentais ou ethos revelador e objetivador da referida escola.

O espaço social assim constituído também se apresentou como meio de interligação dos agentes mobilizados para um projeto coletivo de gestão de sua existência nessa região Transamazônica, conhecidos e reconhecíveis, como advoga Bourdieu, pelas diferenças contrastivas, que assim funcionam como signos distintivos e de distinção, manifestados como princípios de divisão no/do espaço e de visões de mundo.

Esse espaço social constituído por tais agentes abarca campos sociais onde se tecem relações e estruturam-se posições que configuram aquela própria existência social diferenciada. Para o caso estudado, destaco o campo político (representado pelas organizações sociais/sindicais e pelo Partido dos Trabalhadores (PT)), o campo religioso (representado pela Igreja Católica), o campo 
científico-acadêmico expresso pela presença de instituições de pesquisa como o Laboratório Agroecológico da Transamazônica (LAET) e a Universidade Federal do Pará (UFPA).

Aos processos de constituição desses interligados campos sociais, corresponderam outros tantos de territorialização, cujas práticas sociais desenham estratégias de reprodução do grupo mediante recursos/capitais agregados pelos agricultores à visibilidade da especificidade de objetivação da Transamazônica. Eles correspondem, assim, à definição de pertencimentos identitários que tornaram possível a constituição de quadros institucionais emergidos do diálogo entre ação coletiva e ação pública.

Nos processos de territorialização desencadeados pela ação coletiva, inscreve-se a criação de mecanismos políticos de reivindicação e de intervenção por meio de "projetos de desenvolvimento regional". Enfim, investimentos políticos que por sua vez aglutinam as expressões dos investimentos na constituição de trajetórias da ação coletiva, redefinindo espacializações e incorporando novos atores sociais, tanto os que se apresentavam como parceiros, dados os interesses convergentes, como aqueles que quiseram ser reconhecidos por demandas pautadas em interesses contrastivos. Nas duas modalidades de elaboração de projetos, emergem como formulação pública, alguns dos problemas sociais que tornavam visíveis as fontes de precariedade e de instabilidade da condição camponesa, simultaneamente as suas reivindicações e/ou proposições.

Como recurso analítico, considero ação pública os sentidos projetados pelas políticas públicas, os projetos e os programas governamentais/estatais. E por ação coletiva, o conjunto de investimentos postos em prática mediante a formalização de quadros institucionais criados pelos agricultores. Ela consiste na variedade de tipos de ação social no cenário político, econômico e institucional, englobando "[...] desde as manifestações elementares da ação de massa [...] até àquelas marcadas pela presença de estruturas organizacionais racionalmente concebidas para a consecução de fins." (AZEVEDO; PRATES, 1991, p.124).

Valho-me da ideia de ator social para referir-me ao conjunto de agentes coletivos que assim se constituem pelo pertencimento 
a organizações sociais de diversas formas e que atuam com conotação política e/ou cultural. Como agentes, visam, por conseguinte, à dinamização do campo social, pois se inserem nas relações sociais transformando-as (em níveis variados) (TOURRAINE, 1994). Usarei a nominação de ator social ou de organização social para referirme ao conjunto de associações de produtores rurais, cooperativas, Sindicatos dos Trabalhadores Rurais (STR), MPST, FVPP, LAET, dentre outras formas de organização social que têm institucionalidade fundada na ação coletiva. Assim sendo ou por esta perspectiva analítica, a categoria ator social, como aqui assumida, aproxima-se da ideia de agentes sociais correspondente às estruturas mobilizadas que assumem posições nos diferentes campos do espaço social; operam a partir das espécies de capitais pelos quais se posicionam (BOURDIEU, 1989).

\section{Quadros Institucionais Públicos e Resistência Organizada: a mediação do Estado, da Igreja e do Sindicato}

A territorialização da região Transamazônica é um processo que tem como marco a década de 1970, momento no qual se efetiva uma intensificação demográfica, resultante de um conjunto de políticas ligadas ao movimento de expansão da fronteira amazônica e desencadeado pelo Estado, expressiva de sucessão migratória dirigida (VELHO, 1979), via ocupação horizontal da abertura de estradas e projetos de colonização, para expansão econômica brasileira fundada em mega projetos, cuja finalidade era viabilizar a industrialização em larga expansão no contexto de regime militar. Os agentes da ação coletiva, na região polarizada por Altamira, conformam, como já destaquei, um grupo cuja posse da terra deuse com o projeto de colonização.

Nas representações dos agricultores entrevistados, a estrada Transamazônica e o projeto de colonização, viabilizadores da conquista da terra, são valorados como marcadores da ideia de "uma nova era": no que se refere às possibilidades de melhores condições de vida e trabalho na agricultura, bem como uma espécie de ilusão, engano propagandeado pelo Estado, revestido de promessas 
não cumpridas. Ambos teriam funcionado como fatores de atração da migração. A fronteira agrícola constitui-se, portanto, em importante marco da campenização e, por vezes, de recampenização no Brasil; mesmo que dentro de uma lógica perversa de reprodução do capitalismo (VELHO, 1979).

As condições de chegada à região deram-se basicamente de duas formas: por meio do cadastro e assistência do Instituto Nacional de Colonização e Reforma Agrária (INCRA), ou de forma "espontânea”, por meio de locação de caminhões praticada por grupos de famílias vizinhas e/ou parentes:

Eram 12 famílias, se conheceram no caminho [...] só queriam [os servidores do INCRA] gente que tivesse de 4 filhos pra cima [...] nós viemo, quando nós saímos de Goiânia até Anápolis, a gente parecia que ia pro céu! Cheguemo nesse meio de mundo em 71, avistemo que essa estrada não era assim tão boa. [...]. Aí jogaram nós dentro de Altamira. (Colono Pioneiro 1. Ano de chegada: 1971- Informação verbal).

Os meados da década de 1970 e, principalmente, os anos iniciais da década de 1980, na Transamazônica, coincidem com o auge da recessão provocada pela crise do modelo de intervenção estatal via projeto de colonização agrícola. O projeto de colonização fora abandonado pelo Governo Federal, ficando as famílias de migrantes enfrentando as dificuldades de sobrevivência a partir das relações de parentesco, redes de vizinhança e laços de conterraneidade (HÉBETTE, 2002).

A essas redes de solidariedade entre grupos familiares, somamse, aos poucos, os grupos de vizinhos organizados pela Prelazia do Xingu mediante as Comunidades Eclesiais de Base (CEBs), cuja finalidade fora discutir os direitos dos agricultores e a questão fundiária, bem como realizar a alfabetização dos migrantes e seus filhos (em experiências quase informais, dada a ausência do Estado). A Igreja Católica cumpriu a tarefa de organizar essas famílias nas vicinais e, gradativamente, a ação sindical somou-se a essas 
organizações informais, constituindo um espaço semipúblico de resistência e elaboração de projetos coletivos em pequena escala, construídos com o apoio das autoridades religiosas, cujos recursos financeiros advinham da solidariedade internacional das igrejas e de relações pessoais de religiosos (HÉBETTE, 2002).

Dessa forma, pela aglutinação dos colonos em torno dos debates sobre seus direitos trabalhistas, própria da ação sindical, das celebrações religiosas, bem como da escolarização inicial dos migrantes e seus filhos, deu-se o início de uma espécie de comunidade política, neste tempo-espaço orientada pela atuação militante, ao mesmo tempo política e religiosa, capaz de construir a força política mobilizadora da ação coletiva em torno da identidade coletiva de trabalhadores rurais junto à de colonos. A autoidentificação, a partir de uma organização própria e contrária à definição circulada pelo Estado, manifesta um projeto coletivo de resistência a partir do 'trabalho de base'. Este trabalho repercutiu em trocas de serviços mais amplos como hortas comunitárias, ‘jornalzinho', máquinas comunitárias, cantinas e Revendão Comunitário, até o início de mobilizações para a tomada dos STR, no contexto percebido como orientado pelo caráter patronal.

A retirada da ação pública, em 1975, (com o fim do I PIN) desencadeou a construção de ações mais integradas e organizações mais formalizadas para o enfrentamento dos problemas estruturais na região, para o que a organização sindical, já apontada pela ação pastoral como caminho necessário, mostrou-se como possibilidade concreta contra o abandono da ação pública e, ao mesmo tempo, contra a função de vigilância política e clientelística de que se revestiam as ações dos STRs, coordenados por políticos e fazendeiros aliados do projeto político objetivado na Ditadura Militar. Assim, foi se formando, na região, a Corrente Sindical Lavradores Unidos (CSLU), enquanto primeira ação coletiva com forma organizativa mais próxima de uma estrutura institucional e específica dos camponeses, cuja rede de relações se espacializava pela Rodovia Cuiabá-Santarém (BR 163).

Neste quadro, assiste-se gradativamente à configuração de um campo de ações regionalizadas, em que os marcos referenciais 
político-organizativos e religiosos da ação coletiva vão incorporando um conteúdo e demandas mais classistas e sindicais, principalmente em meados da década de 1970 e marcadamente na década de 1980. Entre 1987 e 1991, em intenso movimento social via encontros regionais de lideranças, grupos de agricultores e demais grupos urbanos, como professores, empresários e prefeitos de diversos municípios, discutiam o projeto de colonização e formas de reivindicar ações públicas para enfrentamento do quadro de abandono que repercutia na impossibilidade de permanência e sobrevivência na região. 0 primeiro encontro regional visando a mobilizar os grupos constitutivos da população da Transamazônica a partir dos agricultores ocorreu em julho de 1987, no atual município de Medicilândia.

Dentre os objetivos desse encontro, estava a busca de saídas para recuperar o Projeto de Colonização, o que impunha a necessidade de ações reivindicativas, mas também a formulação de propostas, dada a ausência quase plena da ação pública. Com isto, nas deliberações já se apresentava uma das características que as organizações assumiriam como mediação para o diálogo propositivo -reivindicativo com o Estado, em contexto cuja conjuntura em plano nacional sinalizava ações institucionalizadas dada a parceria com o Partido dos Trabalhadores e a Central Única dos Trabalhadores (CUT), a saber, as pesquisas e o conhecimento sistematizado. A estrutura de legitimidade da ação coletiva associou, assim, a credibilidade das proposições a partir de resultados de pesquisa. Este foi o encaminhamento do primeiro encontro regional, a partir do qual se realizou um diagnóstico socioeconômico, em 1987, pelos então agentes do "Movimento Vida na Amazônia" (famílias de colonos, sindicalistas, professores, membros da Igreja Católica), entre os trechos de Pacajá a Itaituba e trechos da Rodovia Cuiabá-Santarém. Dentre os problemas tornados públicos a partir deste diagnóstico, alguns podem ser revelados nos dados a seguir apresentados: havia nove médicos na região para uma população de 500 mil habitantes, atuando num raio de $1000 \mathrm{~km}$ de distância; havia $2.840 \mathrm{~km}$ de estradas vicinais habitadas sem conservação; nenhum município dispunha de energia elétrica (com exceção de Altamira, mas de forma precária). 
Na culminância da sequência dos encontros regionais, em 1989 é criado o MPST, entidade representativa dos diversos grupos sociais da região, sob a liderança dos colonos agricultores organizados em Sindicatos de Trabalhadores Rurais e com a parceria estratégica local/regional do "grupo dos professores" (que posteriormente viria a formar, na região, o Sindicato dos Trabalhadores em Educação Pública do Estado do Pará - SINTEPP), e da Igreja Católica, mais precisamente, da Prelazia do Xingu. O espaço público das organizações sociais se fortalece significativamente também no cenário nacional, seja com os pares estratégicos como Federação dos Trabalhadores na Agricultura (FETAGRI), CUT e Confederação Nacional de Trabalhadores na Agricultura (CONTAG), seja ainda na esfera político-partidária, tendo em vista a consolidação gradativa do PT com o qual dialogavam as lideranças do MPST e seus pares estratégicos.

Nessa conjuntura e com a legitimidade da pesquisa que fundamentou o diagnóstico socioeconômico, deu-se a construção do $1^{\circ}$ Projeto Global de Desenvolvimento da Transamazônica (PGDT) em 1991, então sistematizado no Grande Acampamento da Transamazônica, realizado em Altamira, no início de junho daquele ano, com a participação efetiva de diversos grupos sociais, representativos de nove dos municípios de influência da BR 230 e da BR 163. Atribui-se ao PGDT o caráter de formulação de primeira política pública na região, cujas ações tiveram importantes repercussões: no contexto de precariedade da educação escolar, foram implantados, pela Secretaria Estadual de Educação, o Projeto Gavião I e II, para capacitação de professores nos níveis de primeiro e segundo graus em todo o Estado; e unidades de Ensino Supletivo em Altamira, Medicilândia e Uruará. Por esses projetos, o Estado se responsabilizava pelo pagamento de professores e a comunidade pela estrutura física.

Os agentes das organizações sociais e demais produtores rurais apresentam, reportando-se a essa trajetória, um eloquente discurso fundador, seja de comunidades nas vicinais, seja das delegacias sindicais e do STR. Eles repassavam a ideia de que a região foi criada a partir da relação com o projeto fracassado de colonização e da 
Transamazônica (a BR tomada ao modo de uma região), no sentido de que a conquistaram, dividiram e a nomearam como resultado das organizações sociais da agricultura de base camponesa. Eles mobilizam esse discurso e/ou sentimento quando falam de si como "nós, os companheiros, colonos da Transamazônica":

Desde o começo, o finado pai foi colono da Transamazônica, ele foi fundador de comunidade, ele era muito ligado a questão religiosa, da igreja, sempre ele era uma liderança, fundou 3 comunidade, desde quando começou a discussão sobre sindicato aqui, eu fui o primeiro tesoureiro da delegacia sindical (Colono Pioneiro 2. Ano de chegada: 1974 - Informação verbal).

Observa-se, na trajetória dos agentes entrevistados, bem como nos documentos das organizações sociais, que se nomear e tornarse visível enquanto 'colonos da Transamazônica' e/ou trabalhador rural revestia-se e ainda se reveste, especialmente em situações públicas da ação coletiva, de uma autorização para falar em nome de uma coletividade criada e abandonada pelos órgãos públicos. Essa denúncia lhes atribui legitimidade e conhecimento coletivo para mobilizar-se, pois que a crença subjetiva da afinidade de origem tornava os colonos entes comuns e, na relação com o Estado e/ou com grupos economicamente adversários, agregava-os enquanto classe mobilizada e mobilizável. A identificação 'colonos da Transamazônica' é tomada como critério político para autonomeação do grupo e como princípio de pertinência ao local, o que igualmente se revestiria de poder simbólico, por construir a unidade interna do grupo e tornar seus membros autorizados para constituir uma visão de mundo e constituir posição para ação no jogo social.

Em uma segunda fase dessas ações regionalizadas com relações institucionais e políticas em âmbito nacional, o MPST e seus pares estratégicos propõem, enquanto projeto de desenvolvimento regional, a retomada do Projeto de Colonização em outras bases; lançando-se o desafio de um novo projeto de desenvolvimento 
alternativo para a Transamazônica tendo como demanda a redefinição de créditos agrícolas e políticas públicas na área de saúde, educação, estradas.

\section{Consolidação de Quadros Institucionais: o desafio da profissionalização e da ambientalização}

No final da década de 1980 e início da década de 1990, alguns fatos econômicos e políticos caracterizadores das práticas produtivas na agricultura concorrem para a construção pública de problemas sociais tornados visíveis sob a mediação de grupos de pesquisa em parceria com as organizações dos agricultores: o declínio produtivo dos sistemas de produção e demanda por formação técnica profissionalizada para o enfrentamento dos constrangimentos ambientais e para constituição de agentes identificados com a luta política, a fim de ocupar aqueles quadros institucionais assim demandantes de saber acadêmico/escolar.

Dentre os motivos daquele declínio dos sistemas de produção, estão os baixos preços, as doenças nas plantações (como vassoura-de-bruxa e fusarium) e a desqualificação do cacau amazônico, considerado refugo na classificação nacional, de tal modo que, em 1988, a Comissão Executiva do Plano da Lavoura Cacaueira (CEPLAC) retirou o fundo de apoio a essa cultura. Ademais, a ausência de créditos agrícolas para os pequenos produtores resultava no uso ampliado do recurso terra, [...] fator (que) provoca a venda da terra, a migração e novos desmatamentos (SABLAYROLLES; ROCHA, 2003, p.192).

Nessa conjuntura, a partir de 1991, para se colocar na negociação com o Estado por créditos agrícolas, sobretudo do FNO, o MPST, articulado regional e nacionalmente com diversos movimentos constitutivos dos interesses do campesinato, encampou um ciclo de mobilizações de massa, através dos "Gritos do Campo" (I, II e III), "Grito dos Povos da Amazônia" e "Grito da Terra Brasil". Segundo Ribeiro (2003, p.40), a Transamazônica foi a região no Estado do Pará que mais contratou financiamentos do FNO Especial. Este fundo é comumente avaliado como uma das maiores conquistas 
por esse quadro institucional da década de 1990, pois garantiu a permanência das famílias nos lotes.

Ao lado dessas conquistas, a já necessária estrutura institucional das organizações sociais demandava um quadro específico de profissionais para assistência e/ou apoio técnico, demanda que se intensificou desde o início das primeiras parcelas dos créditos agrícolas em 1992. Desta forma, forçadas pela evolução diferenciada dos estabelecimentos agrícolas, pois, capitalizadas pela pecuarização via FNO, e pela estrutura de legitimidade institucionalizada, sobretudo do MPST, as organizações buscaram a parceria com entidades e órgãos de pesquisa passíveis de atender a essas demandas que a Fundação FVPP, criada em 1991, já não atendia. Refletia-se, sobretudo, acerca de maneiras mais eficientes de fazer avançar as propostas do PGDT, demarcando um projeto de desenvolvimento, não mais apenas de sobrevivência.

Esses seriam os conteúdos mobilizadores da constituição da parceria com o Programa Agroecológico da Transamazônica (PAET), celebrada entre MPST-STRs e o Laboratório Agroecológico da Transamazônica (LAET/UFPA), em 1993, para o qual se previa um Programa de Pesquisa-Formação-Desenvolvimento a fim de desenvolver pesquisas técnico-científicas orientadas para as demandas da agricultura familiar. Esse programa foi, então, financiado pela Comunidade Europeia, por meio da Cooperação franco-brasileira, no período de 1993 a 1999. O arranjo institucional constitutivo dos novos parceiros estratégicos iniciou-se em 1992, a partir das aproximações com o Centro Agro-ambiental do Tocantins (CAT). A partir de 1993, deu-se a constituição do LAET, em parceria com a EMBRAPA, a Universidade Federal do Pará, com instituições internacionais, sobretudo o Groupe de Recherches et d'Echanges Technologiques (GRET), cuja atribuição era coordenar o Projeto PAET e garantir/colocar profissionais à disposição do LAET. Desde o início, a parceria previa principalmente a promoção do desenvolvimento regional de forma ambientalmente sustentável, tal como era a influência do órgão financiador. As atribuições do LAET consistiam em realizar pesquisa de base e desenvolver tecnologias alternativas. 
$\mathrm{Na}$ confluência desses acontecimentos, em 1993 é realizado pelo LAET, então principal parceiro de diálogo dos atores sociais do campo, a pesquisa-diagnóstico sobre o "Futuro dos Jovens do Campo na Transamazônica". De forma recorrente, os documentos oficiais e trabalhos acadêmicos referem-se a este diagnóstico como o instrumento que expôs, de forma sistematizada, um problema sucessório na agricultura familiar, explicitado pelos seguintes dados: em todos os municípios pesquisados, as famílias possuem em média 4 a 5 filhos, destes, em média 2 ou 3 pretendem ficar na agricultura. Segundo a avaliação do LAET, este número de jovens que projetam permanecer no campo é baixo, considerando a necessidade de mãode-obra familiar na agricultura (STR; FETAGRI, 1999, p.20-22).

Chama atenção o fato de os documentos apontarem, a partir dessa emergência do 'problema da sucessão', para a introdução da demanda de formação de jovens rurais no Programa Agroecológico da Transamazônica, o qual mediava a relação LAET e MPST como instrumento para o desenvolvimento do campo. A isso se acrescentava a possível incorporação da sustentabilidade ambiental, ainda que mais presente enquanto ideal para as lideranças do que para as famílias.

No âmbito nacional, dois fatos contribuem para uma possível diferenciação na agricultura, também marcada pelas exigências de profissionalização e de certa ambientalização - características que se coadunam com as tensões acima mencionadas, bem como as saídas visualizadas pelas entidades de pesquisa em torno da intensificação dos sistemas de produção. Este contexto local e nacional, conforme se vê, levou a quadros de emergência de expectativas em torno dos jovens (mas também dos agricultores como um todo), para além de sua permanência no campo: trata-se de uma permanência em que a educação escolar figura como uma mediação necessária.

$\mathrm{O}$ primeiro fato alude às políticas de crédito agrícolas (nas quais, o FNO especial e posteriormente - em 1996 - o Programa Nacional de Fortalecimento da Agricultura Familiar/PRONAF são criados) que se querem redefinidoras do desenvolvimento rural no Brasil. Se, por um lado, estas atribuem visibilidade à agricultura familiar, por outro, impõem dinâmicas diferenciadas às práticas 
dos agricultores de base camponesa, tanto pela exigência formal da profissionalização dos mesmos para inserção nos mercados agropecuários, em que a escolarização é posta como meio de acesso a este ideal, quanto pelas exigências tácitas através dos discursos do campo político, em que a agricultura familiar é concebida como o "maior segmento da agricultura brasileira, porém, o mais fragilizado em termos de capacidade técnica" (MATTEI, 2006, p.13).

O segundo fato se correlaciona com a presença 'ambientalizada' da parceria PAET na Transamazônica; e diz respeito às discussões no campo acadêmico, notadamente na década de 1990, no Brasil, acerca da agroecologia, bem como com as apostas em termos de militância política em voga desde a década de 1980 e endossada a partir desse campo como condição para efetivar-se o ideal de produção agrícola econômica e ambientalmente sustentável, que exige capacidade gerencial, aptidão à diversificação de culturas e à preservação dos recursos naturais.

Por certo, contribuíram para esta ambientalização os recursos do Programa Piloto para Proteção das Florestas Tropicais do Brasil (PP/G-7) - considerado o maior programa em iniciativas socioambientais no Brasil, - bem como as mudanças recém-introduzidas com as políticas territoriais do Estado. Inicia-se neste contexto, sob a coordenação da FVPP, a denominada fase de experimentação de projetos agroecológicos nos municípios, chamados de Projetos Demonstrativos. Com recursos do MMA e PP/G-7 (liberados a partir de 1999), esta fase teve como principais ações o Projeto Roça Sem Queimar, as Reservas Comunitárias de Porto de Moz, e o Projeto de Valorização e Conservação das Reservas Florestais Legais, nos lotes dos pequenos produtores rurais. Dentre as finalidades do MPST e FVPP, está a difusão de novas técnicas de uso da terra e dos recursos florestais.

Seguramente, isto influenciou a mudança, em 2000, da nominação MPST para Movimento pelo Desenvolvimento da Transamazônica e Xingu (MDTX), o que se afigura como uma forma de colocar-se e/ou manter-se no jogo social, desfrutando e disputando os capitais (simbólicos, materiais/financeiros, sociais) que as nominações legítimas representam. 
Trata-se, portanto, da ambientalização das práticas sociais dos agentes coletivos enquanto um processo sociopolítico em que as ações e relações dos agentes passariam a ser pautadas pelas questões ambientais, preocupação moral com a natureza e a relação do homem com a mesma; preocupação esta definida por Lerrère (1997) como o 'bom uso da natureza', o qual decorre da construção e/ou ampliação do padrão de preocupação moral com os recursos naturais.

É nesse contexto que a gestão política da reprodução do grupo de agricultores coloca, em questão, a educação escolar universal. A baixa oferta de alternativas pelo sistema escolar na zona rural não atenderia às demandas e aos interesses específicos de profissionalizar os agricultores familiares em bases agroecológicas, isto é, enquanto procedimento que viesse a propiciar a permanência deles no campo; bem como não promoveria a identificação das novas gerações com a ideia-valor 'luta', referendada na ação coletiva projetiva de destinos sociais aglutinados por organizações sociais, mas definida em consonância com habitus de classe. Assim, uma das importantes ações do conjunto de atores foi a criação, em 1995, das casas familiares rurais, com especificidade sociopolítica orientada por esses atores e destinada à formação dos filhos dos agricultores, especialmente os que apresentavam participação na trajetória de constituição de quadros institucionais, visto que tal engajamento constituía um dos requisitos para seleção dos jovens mobilizados ou mobilizáveis.

Estariam em jogo, nas finalidades atribuídas à CFR, dois interesses sociais e resultados possíveis: 1) a passagem das propriedades intrínsecas e relacionais constitutivas da trajetória do grupo a estados objetivados, homologados e publicizados em forma de esquemas práticos, ao modo de um habitus de classe; 2) a atualização das regras de sucessão pela necessidade do capital escolar/técnico no gerenciamento dos lotes, bem como de sucessão nos cargos de coordenação demandantes de agentes com espécies de capitais distintos dos possuídos pelas primeiras lideranças.

Com a ampliação de ações com retornos objetivos para os agricultores, dentre outros grupos da Transamazônica, a partir do 
acesso aos recursos financeiros circulados pelo FNO, PRONAF e PP/G-7, bem como com a rede de formação via CFRs, o MPST/MDTX e seus pares estratégicos, constroem-se princípios de legitimidade conquistada no contexto regional e nacional. Por esse movimento social, foram constituídos interlocutores indispensáveis nas diversas instâncias públicas, quer sob ações reivindicativas, ou em função de sua capacidade de influenciar as decisões políticas (HENCHEN, 2002). Os interlocutores conquistaram essa posição tendo em vista o capital social constituído junto aos agricultores e demais atores sociais, bem como junto às instâncias da ação pública como prefeituras, câmara de vereadores, universidades, INCRA, etc.

\section{Considerações Finais}

A análise por mim ensaiada põe, em relevo, a constituição de quadros institucionais como condição fundamental para elaboração coletiva de projetos e destinos sociais que promovam o reconhecimento de uma categoria profissional. As estratégias postas em prática pelos atores têm criado as condições de resistência e de mudança que contextualmente desenhem atributos importantes para o campesinato, ou seja, potencialmente legitimadoras da trajetória coletiva projetada e de sua própria continuidade. Colocar, em relevo, esses processos o é também endossar críticas já reconhecidas no campo acadêmico, que colocam, em questão, as análises tradicionais que preveem o fim das formas camponesas diante do avanço das formas produtivas capitalistas/industriais, mesmo que elas venham sendo referência para grande parte da ação pública.

(1) A primeira característica advém do fato de o tipo de rede de relações constitutivas da posição do campesinato alcançar configurações parcialmente autônomas em relação à sociedade envolvente, tal como demonstra a recorrente criação do papel ou função de mediadores, sejam técnicos para prestação de serviços, sejam políticos. Em quaisquer das situações, o lugar social desses mediadores consiste na articulação entre atores e campos sociais para construção de direitos e recursos. No mais das vezes, tais 
direitos correspondem ao atendimento de interesses específicos, por isso mesmo, capazes de tornar democrática a ação pública e provocar transformações nas relações de poder (NEVES, 2008). Os mediadores mantêm o contato com universos reconhecidamente exteriores, para conhecê-los, enquanto barganham benefícios (econômicos, políticos...).

(2) Esta tendência de constituição de redes pela ação de agentes mediadores, no campo de lutas do campesinato, vem se fundamentando em construção de trajetórias econômicas e políticas e/ou conquistas de espaços coletivos e públicos, cuja origem e atuação tradicionalmente aparecem referendadas em espaços identificados pela territorialidade urbana. A construção de rede de relações tem possibilitado o deslocamento do espaço geográfico das lutas do campo para a cidade. Neste caso, trata-se da cidade política e/ou da cidade econômica (LEROY, 1991), reconhecimento que fundamenta as lutas pela quebra do relativo isolamento físico e social, além de articular as lutas travadas localmente com as grandes questões nacionais e internacionais. 


\section{Referências}

AZEVEDO, S.; PRATES, A. Planejamento participativo movimentos sociais e ação coletiva. In. Ciências Sociais Hoje. São Paulo: Vértice, p.122-152, 1991,

BOURDIEU, Pierre. 0 poder simbólico. Rio de Janeiro: Bertand Brasil, 1989.

HÉBETTE, Jean et al. Reprodução social e participação política na fronteira agrícola paraense: o caso da Transamazônica. In. No mar, nos rios e na fronteira: faces do campesinato no Pará. Belém: EDUFPA, p. 203-232, 2002.

HENCHEN, Mário José. O diálogo com relação entre agricultores e pesquisadores: as experiências do PAET na Transamazônica. (Dissertação de Mestrado em Sociologia). Belém: UFPA, 129 p., 2002.

LARRÈRE, C.; LARRÈRE, R. Do bom uso da natureza: para uma filosofia do meio ambiente. Lisboa: Instituto Piaget, 1997.

LEROY, Jean-Pierre. Uma chama na Amazônia. Rio de Janeiro: Vozes, 1991.

LOPES, J. (Coord). A "ambientalização" dos conflitos sociais. Introdução. In: LOPES, J. (Coord). A ambientalização dos conflitos sociais: participação e controle púbico da poluição industrial. Rio de Janeiro: Relume Dumará: Núcleo de Antropologia da Política: UFRJ, p.17-40, 2004. (Coleção Antropologia a Política, 29).

NEVES, Delma Pessanha. Mediação social e mediadores políticos. In: Desenvolvimento social e mediadores políticos. Porto Alegre: Editora da UFRGS, 2008. 
SABLAYROLLES, P.; ROCHA, C. (orgs). Desenvolvimento sustentável da agricultura familiar na Transamazônica. Belém: AFATRA, 2003.

TOURAINE, A. Crítica da modernidade. Petrópolis: Vozes, 1994.

VELHO, O. Capitalismo autoritário e campesinato: um estudo comparativo a partir da fronteira em movimento. 2. ed. São Paulo: Difel, 1979. 


\title{
III
}

\section{Centro Agroambiental do Tocantins (CAT): concepções situacionais de desenvolvimento rural para a região de Marabá - $P A$}

\author{
Luciano Leal Almeida ${ }^{18}$
}

O Centro Agroambiental do Tocantins (CAT) foi fundado em 1988, como produto de ações institucionais em parceria, envolvendo pesquisadores ligados à Universidade Federal do Pará (UFPA), pesquisadores franceses ligados ao Groupe de Recherche et d'Échanges Technologiques (GRET) ${ }^{19}$ e um grupo de sindicalistas que atuavam na região de Marabá, sudeste do Paráa $^{0}$. O programa de

18 Engenheiro Agrônomo formado pela Universidade Federal Rural do Rio de Janeiro (UFRRJ) e Mestre pelo Programa de Pós-Graduação de Ciências Sociais em Desenvolvimento, Agricultura e Sociedade (CPDA)/UFRRJ. Trabalhou com pesquisas durante a graduação e no mestrado na área de formação de quadros institucionais, sindicalismo rural e relações de mediação/poder na região sudeste do Pará. Atualmente trabalha como indigenista na Fundação Nacional do Índio (FUNAI) em Tucumã-PA. Email: llaleal@yahoo.com.br .

19 É uma associação não governamental, criada em 1970, de apoio à cooperação internacional, à solidariedade profissional e redução da pobreza nos países da Ásia, África, Europa e América Latina.

200 que denomino neste trabalho como "região de Marabá" abrange os municípios de Marabá, Itupiranga, Jacundá, Nova Ipixuna, São João do Araguaia e São Domingos do Araguaia, raio de atuação do Laboratório Sócio-Agronômico do Tocantins/LASAT. Trata-se, pois, de uma denominação fundada na área de atuação de determinadas forças sociais e políticas e não por critérios geográficos. 
ação fundamentado pela criação do CAT projetava, como um dos objetivos, permitir a estabilização da agricultura familiar e consolidar um novo campesinato na fronteira amazônica, buscando também contribuir na discussão da conservação ambiental e uso racional dos recursos naturais. Portanto, prefigurava ações institucionalizadas de mediação entre agricultores organizados por representação política delegada e intercâmbio com porta-vozes de outras instituições, no caso e principalmente, órgãos estatais, inclusive grupos de pesquisa universitários, também associados por parceria com instituições francesas também voltadas para construção sistematizada de conhecimentos entre agricultores.

Partindo do princípio de que as relações de mediação criam vínculos ambíguos, posto que envolvem reciprocidade e dominação, neste artigo apresento alguns dos resultados da pesquisa que realizei sobre a relação estabelecida entre os professores -pesquisadores da UFPA e os porta-vozes do movimento sindical de trabalhadores rurais situados na região de Marabá, diante da criação de um quadro institucional complexo, a partir do final da década de 1980. Procuro entender os significados elaborados por essa mediação institucional e acadêmica no processo de construção de campos de profissionalização dos trabalhadores rurais. Acompanhando compreensivamente esses processos, atribuo a devida atenção à emergência de conflitos e à construção de assimetrias de poder inerentes a essas relações. Por fim, dedico atenção ao estudo das condições em que tais ações assim institucionalizadas influenciaram o desenvolvimento da agricultura familiar na região de Marabá. Para efeitos de contribuição ao conjunto de questões eleitas para a reflexão sobre modos de aplicação de políticas públicas, enfatizo a importância da produção institucional de ideias e valores, bem como a formação de agentes encarregados da difusão

Optei por utilizá-la porque ela possui legitimidade entre os atores locais e sua delimitação espacial se articula com as dinâmicas territoriais que se sucedem nessa porção do estado. Essa região praticamente coincide com a delimitação proposta pela Secretaria de Desenvolvimento Territorial do Ministério do Desenvolvimento Agrário (SDT/MDA) para o território do Sudeste do Pará. 
e reprodução desse mesmo ideário, voltado para projeção de referências de reordenação da vida social e das relações entre grupos, classes e porta-vozes do Estado.

Para entender as ações dos diferentes agentes sociais ao longo do período em que aquele processo teve curso, atribuo atenção ao estudo dos fatos históricos relevantes no período e que foram intervenientes nas ações para constituição dos quadros institucionais. Para tanto, adoto o seguinte procedimento: 1 ) analiso o conjunto de registros impressos, confeccionados pelos diferentes agentes sociais como atas de reuniões, relatórios e ofícios referentes ao Programa; 2) estimulo, por entrevista, a produção de memória recente dos envolvidos nos processos, incorporando 21 interlocutores: pesquisadores, sindicalistas e agricultores que, em diferentes momentos, participaram da construção do CAT.

\section{A Constituição Social do CAT}

O surgimento do Programa CAT se insere no contexto específico de expressão de conflitualidades inerentes à construção da fronteira amazônica no decorrer dos anos de 1970 e 1980, tempo em que melhor se configuraram as expectativas e lutas sociais pela posse da terra na região sudeste do Pará. Essa transformação pautou-se em processos complexos, envolvendo um conjunto de agentes sociais que disputavam o acesso a recursos materiais que dessem conta de projetos de mobilidade e reprodução social como agricultores. A possibilidade de acumular riqueza com a exploração dos recursos materiais e a ausência de um suposto domínio particular sobre as terras estimularam a ocupação do espaço regional; e influenciaram a migração de pessoas de várias partes do país, em especial do Nordeste, em diferentes condições socioeconômicas. Formou-se inicialmente uma economia com base no extrativismo, que influenciou o ritmo de boa parte dos acontecimentos sociais, econômicos e políticos nas décadas seguintes (HÉBETTE, 2004d; ASSIS, 2007).

Até a década de 1970, não existia organização camponesa institucionalizada e a agricultura tinha um papel econômico muito 
secundário no quadro regional, com exceção do arroz e da criação de gado, visto que essas atividades operavam com cadeias de comercialização mais consistentes. A atividade produtiva sobre a qual havia se estruturado a sociedade, ao longo dos séculos, e que sustentava a economia, era o extrativismo nas suas diversas expressões (látex, castanha, caça de animais silvestres e mineração). Os trabalhadores viviam na dependência de patrões e de oligarquias locais. Não havia, por conseguinte, espaço para a organização política formal por esses trabalhadores.

Durante as décadas de 1970 e 1980, a fisionomia econômica e social da região se transformou radicalmente. A mudança se iniciou ainda na década de 1960, quando pequenos agricultores oriundos do Maranhão penetraram nessa região pelo município de São João do Araguaia, mas, dessa vez, não mais apenas para trabalhar nos castanhais e no garimpo, mas para ocuparem "terras livres" ${ }^{21}$, e se sedentarizarem com a formação de lavouras (VELHO, 1974). Essa mudança se acelerou e ampliou fortemente com a abertura oficial da fronteira amazônica durante o regime militar, que decidiu, em 1970, implantar a rodovia Transamazônica e ampliar a infraestrutura regional (hidrelétricas, rodovias, etc.), atraindo migrantes de diversas partes do país.

Segundo Hébette (1996a), a abertura da fronteira amazônica carregou consigo a marca do regime autoritário que a estimulou. A violência que geralmente costuma acompanhar a penetração organizada em "novos territórios" foi reforçada pela violência dos órgãos de repressão instituídos pelo regime militar (Grupo Executivo de Terras do Araguaia-Tocantins/GETAT e o Conselho Nacional de Segurança/CNS ${ }^{22}$. Para o autor, o reconhecimento desse quadro institucional é fundamental para a compreensão dos

21 Concepção que não levava em conta a apropriação dessas terras por povos indígenas.

22 O GETAT foi criado em 1980, seu principal objetivo era suavizar os conflitos agrários na região por meio da ordenação da ocupação. A sua área de atuação correspondeu a região denominada "Bico do Papagaio (ASSIS, 2007). 
processos sociais que vieram paralelamente, em consequência, ocorrer na região de Marabá.

Foi também no bojo desse processo de colonização oficial e/ou espontânea que os posseiros começaram sua organização política. $\mathrm{Na}$ ausência de um órgão legitimamente representativo de seus interesses, os trabalhadores rurais tiveram que investir na criação de suas próprias estratégias de defesa de direito a terra, calcadas em estratégias familiares e de parentesco, de conterraneidade e vizinhança (HÉBETTE, 1996a). Essas estratégias, entretecidas em plano comunitário, forneceram as bases para a constituição das Comunidades Eclesiais de Base (CEBs), estimuladas, nos anos 1970, por religiosos adeptos da Teologia da Libertação, investimento organizativo que recuperou, num nível político mais elaborado e mais consistente, a inspiração dos movimentos de esquerda e a sensibilidade do clero progressista originário da Ação Católica ${ }^{23}$.

Nesse mesmo período, pesquisadores do Núcleo de Altos Estudos Amazônicos (NAEA) ${ }^{24}$ da Universidade Federal do Pará, que também atuavam como assessores desses movimentos organizativos começaram a construir os primeiros contatos com esses migrantes, em sintonia com aqueles espaços de formação organizados por religiosos locais.

Essa luta dos migrantes pela terra constitui-se como campo de encontro de todos os agentes sociais - clero, militantes sociais e políticos, advogados, pesquisadores e estudantes - que lutavam contra o regime militar e a favor dos posseiros. Muitos deles encontravam em organizações das Igrejas Católica e Luterana e, em particular,

23 A Ação Católica Brasileira (ACB) foi um movimento controlado pela hierarquia da Igreja e fundado pelo Cardeal Dom Sebastião Leme e pelo Padre João Batista Portocarrero Costa em 1932. Tinha como um dos objetivos formar leigos para colaborar com a missão social da Igreja e propiciar a presença atuante do leigo católico na vida pública e social do país. Ela se organizou em vários ramos ou grupos como a Juventude Feminina Católica (JFC).

24 O NAEA surgiu dentro da UFPA com a reforma universitária de 1971, funcionando como um órgão de integração dentro da universidade para fomentar a pesquisa e a extensão, voltada, naquela época, por uma série de razões, para a área das Ciências Humanas. 
na Comissão Pastoral da Terra (CPT), um espaço institucional com certa "imunidade simbólica" à repressão. É nesse campo de forças muito diversificadas e, de certa forma, contraditórias - onde a vida política, sindical e religiosa estive tão imbricada em medida e formas diferentes - que os trabalhadores encontraram e constituíram seus primeiros mediadores sociais ${ }^{25}$ (NEVES, 2008).

É, portanto, nesse complexo campo de lutas e resistências que também surgiram as lideranças camponesas que, ao final da década de 1970, foram peças fundamentais na criação dos Sindicatos de Trabalhadores Rurais (STRs); ou, por tais condições sociais e políticas, vieram a conquistá-los, deslocando-os das mãos de dirigentes instalados pelo Instituto Nacional de Colonização e Reforma Agrária (INCRA). Em outros casos ainda, tais sindicatos foram criados, permitindo ampliar a rede institucional de apoio à organização política em construção. Portanto, foi por via do sindicalismo que as lideranças iniciaram sua luta por maior autonomia e começaram a elaborar um projeto coletivo em nível regional de organização da representação política. Aquelas instituições puderam contar ainda com outros apoios como da CPT, muito participativa e dinâmica, também com o apoio do Movimento de Educação de Base (MEB), pesquisadores engajados no estudo e assessoramento dos desdobramentos desses processos; e entidades como a Federação de Órgãos para Assistência Social e Educacional (FASE), Centro de Estudos e Pesquisa e Assessoria Sindical e Popular (CEPASP) e a Sociedade Paraense de Defesa dos Direitos Humanos (SPDDH).

A atuação dessas lideranças nos conflitos por terra que ocorreram, nas décadas de 1980 e 1990, consolidou as entidades sindicais

25 Estamos considerando que os pesquisadores por meio do papel que exercem no CAT e na UFPA atuam como mediadores, bem como os sindicalistas. Os pesquisadores atuariam como elos importantes na estruturação e nas relações de mediação entre esses sindicalistas e outros agentes externos; já os sindicalistas seriam chamados para agirem como elos importantes na estruturação das relações entre agricultores e pesquisadores dentro do CAT. No entanto, estamos considerando que pesquisadores e sindicalistas interagem em múltiplas direções. É de grande relevância, por exemplo, a relação que estabelecem com outros mediadores de outras entidades de apoio e de outras organizações localizados dentro e fora do contexto da região de Marabá. 
como legítimas representantes dos interesses da maioria dos camponeses e trabalhadores rurais na região de Marabá.

De acordo com Hébette (1991), os pesquisadores da UFPA que acompanhavam a dinâmica de ocupação da região eram frequentemente indagados pelos posseiros quanto a seus múltiplos problemas, sem que aqueles pudessem oferecer respostas. Era o caso, por exemplo, dos questionamentos técnicos demandados pelo desejo dos agricultores de incorporarem novas produções, principalmente destinadas ao mercado, isto é, que pudessem complementar as culturas temporárias tradicionais.

Nesse sentido, a forma de uso da terra tinha sido, desde a década de 1980, uma das preocupações dos pequenos agricultores do Pará e de suas assessorias. A resposta a essa preocupação veio a proporcionar o surgimento de novas organizações e de projetos orientados no sentido de soluções especificamente técnicas e econômicas aos problemas. Portanto, voltadas diretamente para a questão da produção e das trocas comerciais.

Esse aspecto foi ressaltado por Leroy (2000), ao apontar que o CAT se insere, em âmbito nacional e regional, num movimento ascendente, embora pouco valorizado, de organização e comercialização da produção. A preocupação, nessa época, era a de empreender políticas duradouras que respondessem estrategicamente às necessidades básicas da categoria socioeconômica, como a implementação e a viabilidade da pequena produção, comercialização e emprego de novas tecnologias.

Assim, o modo como o Programa CAT se estruturou vai refletir o debate que "começou a se dar na época sobre a relação entre o econômico e o político no sindicalismo rural" (Ibidem, 21), pois começavam a emergir os problemas então chamados de "econômicos" da produção e da comercialização agrícola, ao mesmo tempo em que havia a conquista da terra.

Outro aspecto relacionado ao surgimento do Programa CAT diz respeito ao contexto de abertura política que foi se configurando a partir de 1985. Naquele período, a democratização do país permitiu maior abertura e visibilidade a possíveis apoios de cooperação internacional entre a pequena produção agrícola e a pesquisa científica, aproximações que iriam resultar em projetos com ênfase no 
desenvolvimento rural e sustentável em diversas regiões do país. É nesse contexto de apoio externo que o CAT foi gestado, ou seja, por um convênio formulado no quadro da cooperação franco-brasileira. Convém ainda mencionar que a agricultura familiar francesa vinha sendo considerada uma referência para os pesquisadores e planejadores brasileiros e franceses que estavam envolvidos nesse projeto. Esta referência havia justificado, em outubro de 1986, um convênio complementar ao Acordo Geral de Cooperação Científica e Técnica de janeiro de 1967, firmado entre Brasil e França, desta vez, especificamente para a pequena agricultura.

Diante desse contexto, pesquisadores do NAEA e sindicalistas dos municípios de Itupiranga, Marabá, Jacundá e São João do Araguaia, legitimados pelos seus percursos de lutas, consolidaram uma parceria institucional entre esses STRs e a UFPA, no âmbito da cooperação franco-brasileira. Para a efetivação dessa parceria, tais atores contaram, ainda, com a participação fundamental de pesquisadores da Universidade das Antilhas e das Guianas, que já tinham experiências em projetos de cooperação na região do Caribe.

Dessa forma, o Programa CAT surge a partir de demanda que encontra interlocutores, ou seja, pesquisadores sensíveis às demandas das organizações sindicais que, como advogavam, sem abrir mão dos rigores da ciência, iriam atuar como mediadores, visando a propiciar consistência a um projeto de desenvolvimento regional em que os pequenos agricultores estivessem contemplados. Nessa perspectiva, é importante ressaltar também que a demanda desses agricultores da região de Marabá era entendida como algo legítimo por esses pesquisadores, e que todo o processo de construção do Programa se daria a partir do diálogo com os sindicalistas.

Evidências empíricas apontaram a destacada e fundamental contribuição de Jean Hébette na consolidação do CAT, devido, em grande parte, ao seu capital simbólico (de prestígio), ${ }^{26}$ adquirido por sua participação como assessor e pesquisador, em vários anos de pesquisa nessa região. Entretanto, outros agentes (sindicalistas e pesquisadores) tiveram também um papel fundamental na cons-

26 No sentido proposto por Pierre Bourdieu (1989). 
trução de uma rede institucional de viabilização e consolidação da proposta.

Para entender melhor esse processo, as relações de confiança entre pesquisadores, assessores e sindicalistas são elementos importantes, tal como analisei durante a pesquisa. Num primeiro momento, esta confiança estava depositada em algum integrante dessa rede de relações que, por sua vez, iria propiciar as bases para a construção da confiança num terceiro. Da mesma forma, esse processo não se dá sem que haja relações de poder. Isto significa que o estabelecimento da confiança se deu a partir da conjunção de diversos elementos (simbólicos e/ou materiais), a partir dos quais emergiu e se estabeleceu a relação. Ou seja, não fora qualquer agente que desempenhara uma suficiente influência sobre outros, de forma a produzir um efeito de confiança. Nesse sentido, acredito que os atributos de figura de padre/assessor que Jean Hébette carregava, influenciaram as relações de confiança entre agricultores e pesquisadores. Devido ao contexto no qual se dá tal relação, um ambiente rural onde historicamente os agricultores desenvolveram uma acentuada religiosidade e onde entidades da Igreja Católica estiveram atuando intensamente, é verificável a grandeza do poder simbólico da figura de um padre. Portanto, falar de confiança requer uma análise das relações que a geram e, portanto, situá-las histórica e relacionalmente em determinado contexto.

Bourdieu (1989) observa também que, para tentar entender essa força de mobilização que as lideranças possuem, quer a título pessoal, por delegação ou como mandatário de uma organização (partido ou sindicato) detentora de um capital político acumulado no decurso das lutas passadas, é necessário levar em consideração o capital pessoal de notoriedade e de popularidade - firmado no fato de ser conhecido e reconhecido numa pessoa (de ter um nome, uma reputação etc.) e também no fato de possuir certo número de qualidades específicas que são a condição de aquisição e da conservação de uma boa reputação - que cada militante possui, e no qual é:

Frequentemente produto da reconversão de um capital de notoriedade acumulado em outros domínios e, em particular, em profissões 
que, como as profissões liberais, permite tempo livre e supõe um certo capital cultural ou, como no caso dos advogados, um domínio profissional da eloqüência (BOURDIEU, 1989, p.191).

Dessa forma, ao pensarmos na atuação das lideranças ou mediadores sociais como Jean Hébette, é necessário levar em consideração esse "capital de notoriedade acumulado em outros domínios", visto que as diferentes profissões permitem maior ou menor tempo livre destinado às atividades de militância. Também é preciso pensar no acúmulo de determinado capital cultural que está implícito no exercício de algumas profissões, como o hábito de leitura diária, domínio da fala e demais instrumentos que estão diretamente relacionados, principalmente, a profissões como a de pesquisador e padre (que é treinado para ouvir e aconselhar).

Outro aspecto que ainda abordei na pesquisa, enfatiza a abertura da UFPA, por meio do NAEA e desses mediadores institucionais, para a participação em organizações sindicais na definição de um projeto de pesquisa-desenvolvimento para a região de Marabá; e isto sem cair no equívoco de considerá-la como fruto de benevolência dessa instituição (ou desses pesquisadores); ou mesmo do acaso. Essa abertura e essa flexibilidade de funções têm ainda por base o acúmulo de experiências vividas ao longo das trajetórias desses sindicalistas na região de Marabá, que sinalizaram para os pesquisadores do NAEA, a possibilidade de partilhar com as organizações de trabalhadores rurais, uma parcela de responsabilidade da pesquisa e de ações de desenvolvimento rural.

Essa abertura é bastante significativa porque a relação entre sindicalistas e/ou agricultores e pesquisadores e/ou agentes de assistência técnica tinha, em muitos casos, (e ainda continua a ter) um caráter persuasivo, tendo em vista acelerar a adoção de tecnologia ou a busca de alternativas que pudessem contribuir para o desenvolvimento da agricultura familiar, sem, no entanto, criar um espaço de participação crítica dos próprios beneficiários desses projetos, ou seja, do agricultor e de sua família.

Segundo Henchen (2002), era comum considerar o destinatário dos projetos de desenvolvimento como audiência ou como clientela. 
Enfim, uma estrutura de massa amorfa, constituída por uma agregação de indivíduos que, enquanto membros de um determinado grupo, são substancialmente iguais ou igualizáveis, não diferenciáveis, mesmo se pertencentes a ambientes distintos, heterogêneos, com características socioculturais variadas. Nesse sentido, para o autor, era essa visão acerca dos destinatários dos projetos de pesquisa e desenvolvimento rural que contribuía "para o fracasso da maioria dos projetos colocados em prática, porque estes tinham por base uma perspectiva que ignorava o ponto de vista do trabalhador rural sobre as relações nas quais este estava inserido" (HENCHEN, 2002, p. 20).

Ao comentar questões relacionadas às varias percepções sobre o campesinato, Martins (1995, p.17) destacou a importância de ouvir; porém, advertia: deve-se perceber que:

Ouvir o campesinato não quer dizer, simplesmente, partir do próprio discurso dos agentes sociais [...] é preciso mobilizar recursos teóricos que permitam decifrar a fala do camponês, especialmente a fala coletiva do gesto, da ação, da luta camponesa; precisa-se "captar o sentido da fala, ao invés de imputar-lhe sentido, ao invés de desdenhá-la" ( MARTINS, 1995, p.17, grifo do autor).

Por certo, essas questões levantadas pelo autor convergiam ou eram partes da reflexão dos pesquisadores do NAEA/UFPA, quando estes se propuseram a construir uma parceria com sindicatos de trabalhadores rurais.

Por fim, é preciso esclarecer que essa parceria parece surgir como resultado de interrogações dos atores sociais ${ }^{27}$ que se propõem, em um determinado momento de suas trajetórias, modi-

27 Otor social não é aquele que age em conformidade com o lugar que ocupa na organização social, na sociedade, mas aquele que, através de suas ações, modifica o meio ambiente material e, sobretudo, social no qual está inserido; modificando a divisão do trabalho, as relações de dominação e mesmo as orientações culturais (TOURAINE, 1994, p.220). 
ficando o curso de relações anteriormente estabelecidas, sinalizar para a perspectiva de reconstruí-las em outras bases, em outros princípios. Dessa forma, haveria a possibilidade de surgirem relações democráticas e de alteridade entre parceiros/atores que se propunham a construir um projeto em conjunto, onde o diálogo permanente, assim se acreditava, seria da maior importância. Desta maneira, tentava-se evitar a repetição de velhos vícios tão presentes entre instituições ou entre indivíduos vinculados à extensão rural, relações que, em geral, estão assentadas em bases clientelistas, paternalistas, assistencialistas e, consequentemente, autoritárias.

Nesse sentido, se a construção ou a efetivação do Programa CAT podem ser consideradas como construção de um espaço socia ${ }^{28}$ que reunia agentes sociais com trajetórias historicamente distintas, é porque, no percurso dessas trajetórias, esses agentes perceberamse e foram percebidos, tanto dentro como fora de seus respectivos campos de ação, de sua área de atuação, como portadores de certa distinção, que lhes proporcionava visibilidade política e social, mas também certa convergência de objetivos e projeções.

A visibilidade e, de certa forma, a especificidade dessas ações são elementos chave que proporcionavam o reconhecimento de atores sociais históricos e sinalizam para o fato de que estes se encontram na condição de delegados, isto é, de alguém que dispõe de certa autorização social que lhes permite a negociação construtiva de um Programa, no qual estivessem envolvidas atividades de pesquisa, formação e ações de desenvolvimento, não mais em situação subalterna, mas agora, na condição de parceiros.

28 A noção de espaço social, conforme afirma Pierre Bourdieu: "Contém, em si, o princípio de uma apreensão relacional do mundo social: ela afirma, de fato, que toda "realidade" que designa reside na exterioridade mútua dos elementos que a compõem. Os seres aparentes, diretamente visíveis, quer se trate de indivíduos quer de grupos, existem e subsistem na e pela diferença, isto é, enquanto ocupam posições relativas a um espaço de relações que, ainda que invisível e sempre difícil de expressar empiricamente, é a realidade mais real (...) e o princípio real dos comportamentos dos indivíduos e dos grupos" (BOURDIEU, 1996, 46). 
Assim sendo, as lideranças dos sindicatos representados no CAT, com base em suas experiências de luta, nos seus enfrentamentos e/ ou negociações com o Estado, acreditava-se credenciadas, isto é, possuidoras de uma espécie de delegação ${ }^{29}$, que, de certa forma, as autorizava a falar em nome dos sindicatos, das delegacias sindicais, ou, de um modo geral, em nome dos pequenos agricultores e posseiros daquela região. Essa delegação, por certo, fora constituída enquanto resultado das trajetórias de luta, o que, portanto, lhe conferia legitimidade de ir ao encontro dos pesquisadores do NAEA, que já atuavam na região de Marabá, há algum tempo, desde meados da década de 1970 .

\section{Estrutura e ações do Programa CAT}

Alguns princípios consensuais orientaram a montagem do Programa CAT. Pretendia-se uma parceria baseada no diálogo entre lavradores, pesquisadores e técnicos. De acordo com Hébette \& Navegantes (2000), os princípios da parceria foram:

1) Uma parceria entre lavradores e instituições de pesquisa e ensino que passasse por uma organização representativa de trabalhadores rurais, mais especificamente dos STRs, legitimados por seu apoio à luta dos posseiros.

2) A importância da pesquisa agronômica e social permanente associada à organização camponesa para identificar sistematicamente as necessidades dos trabalhadores rurais e propor respostas.

3) A escolha de uma escala regional que oferecesse ao projeto a possibilidade de um impacto na área coberta pelos quatro

29 De acordo com Bourdieu (1989), o homem que possui capital político retira sua força política da confiança que o grupo põe nele. Ele retira o seu poder propriamente mágico sobre o grupo da fé na representação que ele dá ao grupo e que é uma representação do próprio grupo e da relação com os outros grupos. Mandatário unido aos seus mandantes por uma espécie de contrato racional - o programa -, ele é também campeão, unido por uma relação mágica de identificação àqueles que, como se diz, põem nele todas as esperanças (BOURDIEU, 1989). 
STRs com os quais já se tinha experiência de trabalho: os de Itupiranga, Jacundá, Marabá e São João do Araguaia, abrangendo uma área, na época, de cerca de $35.000 \mathrm{Km}^{2}{ }^{30}$

4) Ação que atingisse a mais ampla base camponesa, tentando levá-la adiante em conjunto, com objetivo de evitar a formação de segmentos privilegiados dentro de cada categoria.

5) Um horizonte temporal amplo, de esforço de desenvolvimento, calculado como equivalente a uma geração, para alcançar resultados satisfatórios e duráveis.

6) A implantação de um centro de encontros e reuniões que pudesse propiciar intercâmbios frequentes entre trabalhadores rurais e entre eles e os pesquisadores e técnicos.

Sua estrutura básica foi constituída por duas entidades fundamentais: a Fundação Agrária do Tocantins-Araguaia (FATA) e o Laboratório Sócio-Agronômico do Tocantins (LASAT), que se articularam, não sem conflitos, para pensar conjuntamente as diversas atividades que foram realizadas. No entanto, algumas atividades se realizaram sem a comunicação preconizada entre sindicalistas e pesquisadores, como, por exemplo, o Projeto Agro-Florestal (PAF) - o maior projeto do CAT em vários aspectos, que foi perpassado por meio de conflitos entre sindicalistas, pesquisadores do LASAT, a coordenação do CAT e financiadores estrangeiros. Outras entidades foram criadas no Programa à medida que avançaram as questões de comercialização - COCAT (Cooperativa Camponesa do Araguaia-Tocantins) - e de formação e escolarização de sindicalistas e jovens agricultores - EFA (Escola Família Agrícola).

Para pensar as ações conjuntamente, foi construída, em um sítio a 8 km de Marabá, uma estrutura física ou institucional, considerada por alguns atores regionais como "grande demais" para ser

30 Posteriormente mais dois municípios integraram o programa CAT: Nova Ipixuna, município que se emancipou de Itupiranga, foi integrado em 1996; São Domingos do Araguaia, município que se emancipou de São João do Araguaia foi integrado em 1993. A entrada desses dois municípios relaciona-se ao fato de serem áreas onde o Programa CAT já tinha atuação e que foram simplesmente desmembradas em novos municípios, não gerando, dessa forma, novas despesas para o Programa. 
apropriada pelos agricultores, contendo vários prédios e uma área experimental para a realização de atividades produtivas e de lazer. O Centro de Convivência da FATA (CECON) ou simplesmente CAT, como ficou mais conhecido, foi constituído de três salas de aula, o auditório (que, na maioria das vezes, serve como sala de aula), oito dormitórios para educandos, refeitório, cozinha, biblioteca, prédio administrativo, espaço de recreação com campo de futebol e quadra de areia.

Pela análise do material empírico também pude ressaltar que essa estrutura encontra-se hoje degradada, devido, em parte, à falta de recursos para a manutenção e conservação dos prédios, principalmente a partir de 2001, quando a FATA se integrou a FETAGRI regional. Atualmente, o movimento sindical entabula um debate com outras entidades da região, no sentido de resgatar o valor simbólico, material e político do Centro de Convivência da FATA, para além dos espaços de formação e escolarização que acontecem ali por meio da EFA.

Para efetivação das atividades, decidiu-se, desde o início, formar equipes permanentes de pesquisadores instalados na região, que trabalhariam em parceria contínua com as organizações sindicais. O fato de residir na região era condição imprescindível à integração e ao acompanhamento das ações de desenvolvimento. Quanto à duração, por tempo indeterminado, dos trabalhos da equipe, ela foi fundamentada na constatação de que uma intervenção de desenvolvimento sustentável só poderia ganhar consistência a médio e a longo prazo, sobretudo na escala considerada, bem como no interesse em integrar a formação superior como um dos componentes principais do projeto.

As equipes de pesquisa eram formadas por pesquisadores e técnicos nomeados, na sua maioria, por instituições ligadas ao projeto. Esses pesquisadores foram alocados no interior das áreas rurais, para a implementação da pesquisa. Os objetivos principais dessa pesquisa-ação foram negociados periodicamente e os temas eram debatidos em espaços como os Estágios de Base e Temáticos. Os pesquisadores consideraram implicitamente, no início dos trabalhos, que a aproximação entre a demanda dos sindicalistas e a oferta dos pesquisadores se faria progressivamente, graças à 
renegociação periódica das bases da pesquisa-ação, depois de avaliações conjuntas dos resultados e dos métodos empregados. Essa negociação periódica deveria também esclarecer, paulatinamente, as estratégias das instituições parceiras, de forma a identificar melhor os campos de cooperação, permitindo, assim, um benefício recíproco.

Os pesquisadores esperavam que esse tipo de metodologia permitisse reforçar as dinâmicas democráticas e a capacidade de os produtores influenciarem o desenvolvimento, elaborando, em parceria com os pesquisadores, o conhecimento da realidade, a busca de alternativas e a aplicação das soluções. A pesquisa participativa deveria atuar sobre os processos de transformação da sociedade de acordo com os produtores familiares. Isso condicionava o estabelecimento de uma verdadeira parceria com os produtores, baseada em respeito e confiança mútua, porém não sem conflitos e permeados por relações de poder.

A formação de pesquisadores e técnicos de nível superior foram outras atividades que tiveram grande visibilidade durante o Programa, principalmente no LASAT. Essas atividades tiveram início com o DAZ (Curso de Especialização em Agriculturas e Desenvolvimento Amazônico) em 1991 e se consolidaram com a criação do NEAF (Núcleos de Estudos Integrados sobre Agricultura Familiar), em 1994, dentro do Centro Agropecuário da UFPA. Posteriormente, foram criados cursos de graduação em Marabá e em Altamira, ajudando na disseminação da metodologia de pesquisa participativa preconizada pelo LASAT. Atualmente, este órgão mantém parcerias com outras organizações sociais (não só os sindicatos ligados à FATA) para elaborar temas de pesquisa.

As dificuldades entre pesquisadores e sindicalistas podem ser explicadas pelas diferenças que estes agentes e pela própria diversidade de formação, cultura, funções e interesses em jogo. Os sindicalistas, na maioria das vezes, identificaram- se com base em critérios políticos, pela defesa de uma categoria social ampla e definida a partir de critérios de classe social. Sua militância sindical foi definida em termos de alianças táticas, e procuram orientar os resultados de sua atividade de maneira a favorecer seus aliados 
e a desenvolver sua base, a partir das demandas que envolviam o fortalecimento econômico dos agricultores. Os pesquisadores, por sua vez, qualquer que seja seu engajamento político, para sobreviverem profissionalmente, deveriam obter reconhecimento no campo científico, o que supõe produtos científicos reconhecidos e, portanto, tipos de intervenção compatíveis com esse objetivo (GUERRA; CASTELLANET, 2005).

A existência de campos de interesse e de poder extremamente diferentes, de concepções de desenvolvimento e do papel do pesquisador igualmente diversos, tornou difícil a elaboração de uma aliança equilibrada, em que cada um se beneficia do outro sem ameaçá-lo (GUERRA; CASTELLANET, 2005). Pode-se concluir que a elaboração de uma estratégia conjunta entre dois grupos sociais muito diferentes requer muito mais do que o estabelecimento de um diálogo e do compartilhamento das regras do jogo.

Parece-me, entretanto, que foi possível chegar a um equilíbrio negociado nessa relação, a partir da identificação rigorosa de campos de interesses comuns bem definidos e, por contraste, de campos reservados, em que cada parceiro entende preservar sua supremacia e sua demanda, incitando o outro a minimizar sua interferência. Podem-se imaginar também as regras que permitiriam minimizar as zonas de fricção e de competição, e maximizar as áreas de cooperação e de interesse mútuo. 0 arranjo pressuporia uma negociação sobre o controle e a autolimitação tão caros aos pesquisadores, que não poderiam aceitar a renúncia a certos direitos, e de sua prática científica, em particular não aceitar não se imiscuir na política interna das organizações e respeitar a obrigação de confidencialidade em relação a certas informações consideradas estratégicas para as organizações de produtores (GUERRA; CASTELLANET, 2005).

Dessa forma, a coconstrução de novos conhecimentos, juntando o saber dos agricultores e conhecimento dos pesquisadores não foi uma tarefa simples, pois o relacionamento é uma construção social. Diálogo, parcerias, alianças não são instituídos a partir da definição de responsabilidades, direitos, deveres e regras do jogo bem redigidas no papel, e sim, são resultantes da forma como um percebe 
o outro e nas suas ações, atitudes, comportamento ao longo do cotidiano e do reconhecimento de alteridades (HÉBETTE, 1996b). Nessa perspectiva, a necessária oposição de saberes tornou-se a base de uma metodologia educacional de troca, em que os conhecimentos e práticas existentes se confrontavam e se transformavam em novos conhecimentos e práticas. Portanto, instrumentos que potencializavam a produção e possibilitavam um maior espaço de afirmação dos camponeses na cena política da região de Marabá, principalmente na segunda metade da década de 1990.

\section{A atuação do CAT na região de Marabá}

Dez anos depois do fim dessa experiência em 2001, resultados significativos para a região foram obtidos por ambas as partes. Porém, constatamos que o Programa CAT não pode servir de um elemento explicativo para todas as transformações que aconteceram na região de Marabá na década de 1990 e início do século XXI. Pois, nesta região, historicamente formada por processos sociais complexos e diversos, existiam outros atores presentes, como, por exemplo, a FASE, a CPT, o CEPASP e algumas ONGs atuando em várias frentes e com objetivos diversos. Nesse sentido, não dá para fazer uma separação clara entre o que foi resultado das atividades do Programa CAT e das outras entidades.

Mesmo com essa diversidade de agentes, alguns entrevistados enfatizaram que o Programa CAT contribuiu em vários aspectos para a região de Marabá. Por exemplo: o crescimento do número de associações e cooperativas, a capilaridade e legitimidade do movimento sindical nas delegacias sindicais, o aumento do debate sobre as políticas públicas para a agricultura e o acesso dos agricultores às políticas de crédito. No domínio da transformação, da industrialização e da comercialização dos produtos agrícolas, foram constituídas entidades, como cooperativa voltada para o desenvolvimento, no entanto, conservando uma perspectiva de luta sindical (COCAT). E no plano da assistência técnica, a COOPSERVIÇOS. No plano da formação e escolarização de jovens agricultores, a criação e consolidação da EFA, considerada pelos atores públicos regionais um dos passos mais significativos. Porém, o mais provável é que 
essas transformações na região pudessem ser resultado de outros processos que ocorriam paralelamente à atuação do CAT ou da combinação desses elementos.

Houve também muitos debates e alguns projetos realizados no âmbito da FATA, com o intuito de discutir com os agricultores um novo modelo de agricultura sustentável que fugisse do padrão de pecuarização que estava se dando de forma intensa no sudeste do Pará. Nesses espaços, tentava-se colocar para os agricultores a importância da diversificação da produção no lote e o investimento em outras culturas. Entretanto, a forte presença da pecuária permanecia como questão importante:

Na região de atuação, a principal cultura, se a gente entrar nos lotes, é o capim, é o pasto, é leite, é o gado. Então, por uma série de fatores, nós não conseguimos fazer com que aquela iniciativa dos plantios se transformasse de fato, se desenvolvesse para virar plantio dos agricultores, em pomares e tal (Entrevistado 03 - Sindicalista-Informação verbal).

Mesmo assim, alguns entrevistados consideraram que houve indicações de algumas mudanças positivas no sentido de pensar um novo padrão de alimentação para as famílias que participaram dos projetos na FATA e nas comunidades que foram atendidas, em torno de três mil famílias. Atualmente, existem também alguns agricultores que continuaram com plantações de frutíferas e deram continuidade às experiências de diversificação, mesmo depois de terem acabado os projetos de apoio.

As indicações dos entrevistados reafirmam alguns dados que foram discutidos por Solyno Sobrinho $(2004)^{31}$. Segundo esse autor,

31 Solyno Sobrinho teve uma participação essencial em um dos projetos do CAT. Em sua dissertação de Mestrado (SOLYNO SOBRINHO, 2004), analisou o ambiente institucional que orientou a exploração dos recursos na região de Marabá, particularmente no que diz respeito aos impulsos que deram suporte à pecuária bovina como atividade principal da economia rural da região, e seus efeitos nas unidades de produção familiar. Devido à importância e a abrangência de sua análise, 
apesar do significativo volume de recursos aplicados, nos últimos 20 anos, em projetos de apoio ao desenvolvimento e diversificação da agricultura familiar na região de Marabá (entre eles o Programa CAT), hoje, mais do que nunca, predomina a pecuária extensiva nos estabelecimentos familiares ${ }^{32}$.

Ele ainda comenta que, no final da década de 1990, a maioria dos consórcios de culturas permanentes que foram financiados, estava abandonada, remanescendo apenas aqueles que escaparam do fogo e os que estavam bem situados em relação ao mercado, razão pelo qual os agricultores passaram a dedicar-lhes uma maior atenção. Também influenciando a baixa performance na manutenção desses plantios, não prosperaram as iniciativas de beneficiamento e comercialização, que poderiam incentivar a manutenção e ampliação dos plantios com um melhor retorno dos agricultores.

De acordo com o autor, ocorreu uma rápida expansão da pecuária extensiva na década de 1990 na região de Marabá, "arrastando consigo a agricultura familiar para o absoluto domínio das pastagens, uma monocultura que inviabiliza outros possíveis usos da terra, e qualquer possibilidade de desenvolvimento sustentável baseado na diversidade" (Ibidem, p. 11).

De maneira semelhante, outras condições institucionais, em especial a política de crédito agrícola, estimularam a pecuária extensiva como opção preferencial de desenvolvimento da agricultura familiar na região de Marabá, condenando as experiências de desenvolvimento sustentável a "meros ensaios pontuais e isolados da realidade mais abrangente da região, com poucas chances de viabilidade econômica em um mercado que se organiza em escala somente para os produtos da pecuária" (Ibidem).

Nessa circunstância, o autor concluiu que seria:

Ingenuidade pensar que os simples experimentos pontuais estimulados pelo PPG7 na

utilizarei daqui para frente alguns elementos utilizados por ele para entender a atuação do Programa CAT na agricultura familiar dessa região.

32 Em que pese o uso de tecnologia muito elevada (como o uso de insumos), ela vem obtendo índices elevados de produtividade. 
década de 1990 em Marabá pudessem provocar uma revolução ambientalista na maneira de produzir dos camponeses. Quando se analisa o papel da pecuária na história econômica da região de Marabá, verifica-se que a atividade tem origens congênitas, inclusive na formação do campesinato na região, que ocupando áreas de difícil acesso, ou mesmo áreas já tomadas por pastagens no caso da ocupação de fazendas improdutivas, não vê outra opção melhor que a pecuária para alcançar certa estabilidade do padrão de reprodução da família (SOLYNO SOBRINHO, 2004, p.122).

Por outro lado, ele enfatizou que as soluções agroecológicas introduzidas na região pelos projetos de cunho ambientalista (o PAF, por exemplo), caracterizam-se pelo experimentalismo, razão pela qual não se mostraram tão replicáveis nas condições que se encontrava a região, principalmente pela fragilidade do mercado para produtos agroflorestais alternativos. Além disso, condicionados à exigência de um conhecimento ecológico local (que não se encontra entre os agricultores - a maioria formada de migrantes, vindos do Nordeste), e às restrições de cada tipo de estabelecimento, foram raros os exemplos de práticas agroecológicas que puderam se reproduzir em larga escala.

Numa outra perspectiva de análise, concluímos que os ganhos dos pesquisadores estavam mais relacionados aos bens que mais lhes agregam poder, que são os do tipo simbólico (reconhecimento acadêmico, divulgação de pesquisas) e, em certo sentido, recursos para a mobilização de pesquisas, fortalecendo também a instituição na qual representavam - visibilidade da UFPA tanto nacional quanto internacionalmente.

O trabalho iniciado com as organizações sindicais permitiu também aos pesquisadores uma penetração em diversos níveis das comunidades rurais, alcançando até os povoados mais distantes dos municípios. Essa proximidade permitiu constatar que a ação sindical, apesar de seu impacto real no campesinato, deixou 
a desejar no sentido de que existem agricultores que resistem ao engajamento social, em razão de posições políticas contraditórias com o discurso dessas entidades, ou de afinidades com outras forças não alinhadas a esse tipo de trabalho. Relações de clientelismo, paternalismo, distância geográfica ou outros interesses impediram a inserção completa da massa de agricultores no seio dessas organizações, que não escapam à regra e reproduziam frequentemente relações da mesma natureza.

Análises empíricas também me indicaram que era raro que verdadeiros debates tenham acontecido nas Assembleias Gerais da FATA $^{33}$. Tratava-se, em grande parte, de confirmar os acordos preparados antes, por contatos diretos ou negociações nos bastidores. Discussões sobre a representatividade dos sindicatos ou os modos de designação de seus responsáveis foram encarados como interferências inaceitáveis dos pesquisadores nas organizações sindicais, motivo por que foram cada vez menos convidados a participar das reuniões. Esse momento de maior conflito se deu a partir da consolidação da FETAGRI regional sudeste como o grande fórum articulador das políticas sindicais no final da década de 1990, contribuindo significativamente para a desestruturação do Programa CAT. Nesse sentido, os pesquisadores foram mantidos à distância do funcionamento das organizações sindicais, a fim de evitar qualquer risco de manipulação e de tomada de poder pelos intelectuais, bem como a interferência na gerência dos recursos disponibilizados, principalmente no âmbito da FATA.

Deve-se considerar que as características das relações analisadas nesse trabalho, desde uma perspectiva crítica, não eliminam a constatação de que todos esses agentes estiveram guiados por uma utopia, qual seja a construção de uma nova realidade social. Realidade esta que seja regida por valores de justiça, igualdade social entre os seres humanos numa região historicamente marcada pelo contexto da exploração e da violência. E é assim, mirando este ideal que os pesquisadores, sindicalistas, agricultores e assessores

33 Ocorria uma vez ao ano e reunia sindicalistas, pesquisadores e agricultores para tratar das decisões no âmbito da FATA. 
de diversas entidades lutaram por uma transformação política e social na região de Marabá.

Por este exercício, quero afinal destacar o papel da produção de ideias coletivas para influenciar a elaboração de outros ideários, pelos quais uma política pública passa a fazer sentido. Se o engajamento daqueles agentes na produção de outros sistemas de crenças de reordenação da vida social não alcançou moldar os programas emanados do Estado, essa avaliação não pode estar assim limitada. Daqueles agentes, muitos deram continuidade ao exercício de formação de novos profissionais para a prática intervencionista na agricultura, para a mobilização de agricultores segundo interesses mais contextuais. E os agricultores, adequando-se a referências de outros contextos, construíram outras instituições e encaminharam filhos para o ensino universitário de graduação e pós-graduação, boa parte deles hoje ocupando postos centrais na objetivação de outros ideários de sustentabilidade e responsabilidade social para a agricultura no Brasil e em Marabá. 


\section{Referências}

ASSIS, William Santos de. A construção da representação dos trabalhadores rurais do sudeste paraense. Rio de Janeiro: CPDA/UFRRJ. (Tese de Doutorado), 2007.

BOURDIEU, Pierre. O poder simbólico. Lisboa: Difel, 1989.

Razões práticas: sobre a teoria da ação. Campinas: Papirus, 1996.

. Contrafogos 2: por um movimento social europeu. Rio de Janeiro: Zahar, 2001.

HÉBETTE, Jean. O centro Agroambiental do Tocantins: propostas e desafios. Texto publicado in Proposta. Rio de Janeiro, XV (48), 32-37p, mar. 1991. In: HÉBETTE, J. Cruzando a fronteira: 30 anos de estudos do campesinato na Amazônia. Belém: EDUFPA, v. IV, 2004d.

- Reprodução social e participação política na fronteira agrícola paraense: o caso da Transamazônica. Texto apresentado no painel Movimentos Sociais Contemporâneos da BRASA Third Conference, em Cambridge, 07-10.09.1996a. In: . Cruzando a fronteira: 30 anos de estudos do campesinato na Amazônia. Belém: EDUFPA, v. IV., 2004d.

A relação pesquisadores-agricultores: diálogo, parceria, aliança? Uma análise estrutural. Texto apresentado no seminário Pesquisas para o desenvolvimento sustentável da agricultura familiar amazônica, promovido pelo NEAF em 1996b. In: Cruzando a fronteira: 30 anos de estudos do campesinato na Amazônia. Belém: EDUFPA, v. IV., 2004d.

Movimento sindical e ações de desenvolvimento rural: a construção de um nível regional de ação em parceria. Texto publicado no Seminário A construção local do território na Amazônia Oriental. 
Elementos para a construção de uma parceria entre organismos regionais em vista de um desenvolvimento, promovido pelo NEAF/UFPA, em Marabá, 19-21.03.1997. In: HÉBETTE, J. Cruzando a fronteira: 30 anos de estudos do campesinato na Amazônia. Belém: EDUFPA, v. IV., 2004 d.

HENCHEN, Mario José. o diálogo como relação entre agricultores e pesquisadores: a experiência do PAET na Transamazônica. (Dissertação de Mestrado), Programa de Mestrado em Sociologia: Universidade Federal do Pará, 2002.

GUERRA, G. A.D.; CASTELLANET, C. Pesquisadores engajados e líderes camponeses na pesquisa-ação: uma cooperação conflitante. Reflexões a partir dos programas CAT e Paet na Amazônia brasileira. Cadernos de Ciência \& Tecnologia, Brasília, v. 22, n. 2, p. 333-347, maio/ago. 2005.

LEROY, J.P. Da Fronteira sem lei nem direitos a uma democracia em construção: o campesinato da região de Marabá nos anos 80 e a criação do CAT. In: HÉBETTE, J.; NAVEGANTES, R. (orgs). CAT - Ano décimo: etnografia de uma utopia. Belém: UFPA: CAT, 2000.

MARTINS, José de Souza. Os Camponeses e a política no Brasil. Petrópolis: Vozes, 1995.

NEVES, D. P. Mediação social e mediadores políticos. In (Org). Desenvolvimento social e mediadores políticos. Porto Alegre: Editora da UFRGS: Programa de Pós-Graduação em Desenvolvimento Rural, 2008.

SOLYNO SOBRINHO, S. A. Constrangimento institucional para o desenvolvimento sustentável da agricultura familiar na região de Marabá. (Dissertação de Mestrado) NAEA: Universidade Federal do Pará, 2004. 
SOUZA, D. D. L. de. Organizações não-governamentais: um estudo de caso da Federação de Órgãos para a Assistência Social e Educacional (FASE). (Tese de Doutorado). Porto Alegre: UFRGS: Programa de PósGraduação em Educação, 2005.

TOURAINE, Alain. Crítica da modernidade. Rio de Janeiro: Vozes, 1984.

. Capitalismo autoritário e campesinato: um estudo comparativo a partir da fronteira em movimento. 2. ed. Rio de Janeiro: São Paulo: DIFEL, 1974.

WEBER, M. Economia e Sociedade: Fundamentos da sociologia compreensiva. 3. ed. Brasília: Editora da UNB, 1994. 


\section{IV}

\section{Incra como Ator-Rede: estudo das relações entre os servidores da SR-27}

Camila Penna ${ }^{34}$

O INCRA (Instituto Nacional de Colonização e Reforma Agrária) foi criado em 1970, pelo Decreto-lei 1.110, editado pelo governo militar. Quando de sua criação, a função principal do Instituto era a de colonização, notadamente colonização da região amazônica. Nesse sentido, dois dos principais programas eram o PROTERRA (Programa de Redistribuição de Terras), cuja meta era ocupar as áreas desabitadas da Amazônia por meio da distribuição de terras; e o PIN (Programa de Integração Nacional), cujo propósito era ocupar parte da Amazônia com a criação de agrovilas em torno da Transamazônica (INCRA, 2000).

As políticas de incentivo à ocupação da região do sul e sudeste do Pará resultaram em fluxos de migração distintos. A partir principalmente dos anos 1970, ocuparam a região do sul e sudeste do Pará não só trabalhadores rurais assentados pelo INCRA, mas também grandes produtores rurais pecuaristas, grandes empresários do sul e do sudeste, madeireiros e empresas mineradoras. Nessa configuração decorrente da aglutinação de diferentes atores, referenciados a diversas formas de ocupação da terra, aliada à falta de

34 Doutoranda em Sociologia na Universidade de Brasília. camilapenna2003@yahoo. com.br 
regulamentação e sobreposição da posse, a região passou a se destacar por uma alta conflitividade relacionada à disputa por terra. Entre os anos 1970 e 1990, as emergentes organizações de trabalhadores rurais se articularam e passaram a coordenar estratégias de luta (ASSIS, 2009), tornando-se, então, os principais interlocutores do INCRA na região (as três principais organizações de trabalhadores da região com as quais o INCRA dialoga são MST, FETAGRI e FETRAF).

Diante desses novos fatores, o governo militar cria, em 1980, o GETAT (Grupo Executivo de Terras do Araguaia-Tocantins), com o propósito de controlar o conflito agrário, na região, por meio da regularização fundiária. O Getat tinha sede em Marabá, onde se localiza hoje a SR-27. Muitos dos servidores ${ }^{35}$ da superintendência foram contratados ainda na época do GETAT. Eles se referem àquele período como um dos que mais se tinham recursos, o que lhes permitia realizar um trabalho mais eficiente.

O GETAT é extinto em 1987, no contexto dos processos de redemocratização; e suas competências foram transferidas para o INCRA. A sede em Marabá se torna Unidade Avançada ${ }^{36} \mathrm{da}$ Superintendência de Belém (SR-01). Contudo, em 1996, com o massacre de trabalhadores rurais ligados ao MST em Eldorado dos Carajás, de grande repercussão na mídia nacional e internacional, porta-vozes dos movimentos demandaram a transformação da Unidade de Marabá em Superintendência autônoma e com mais poderes. Alguns funcionários que trabalhavam lá, nesse momento,

350 termo servidor utilizado aqui se refere tanto aos funcionários concursados, também denominados "servidores da casa" ou "funcionários de carreira"; quanto aos funcionários que não são concursados, mas têm cargos de confiança, são contratados por meio de empresas terceirizadas ou por meio de convênios com prefeituras. Os servidores que não são "da casa" geralmente são denominados pelos funcionários de carreira como pessoas "de fora”.

36 Unidades avançadas são “órgãos descentralizados, de caráter transitório, subordinados às superintendências regionais". Tem como atribuição executar atividades finalísticas tais como "articular-se com os organismos governamentais, não governamentais e os beneficiários, no sentido de viabilizar a participação e a integração das ações nos projetos de reforma agrária de colonização" (Regimento Interno, 2009, art. 118, Inciso III). 
destacam que, com a criação de uma Superintendência em Marabá, ficaria mais próximo e mais fácil para os respectivos representantes dos movimentos da região, que antes tinham que se deslocar até Belém para entrar em contato com o superintendente.

A partir de 1996, é criada então a SR-27, superintendência de caráter especial, com sede em Marabá, mas tendo por área de competência a região sul e sudeste do Pará. Atualmente, no Estado do Pará existem três superintendências: Marabá (SR-27), Santarém (SR-30) e Belém (SR-01). Essas superintendências abrigam 25\% das famílias assentadas pelo programa de reforma agrária em todo o Brasil $^{37}$. Do total de famílias assentadas no Pará, 30\% estão na área de competência da SR-27.

A força de trabalho total da SR-27 é de 223 pessoas - 123 na sede, em Marabá, 70 nas Unidades Avançadas ${ }^{38}$, e 25 no Terra Legal. Grande parte dos servidores da SR-27, notadamente os lotados nas Unidades Avançadas, foi contratada na época do GETAT, em regime de CLT; depois se submeteram a um concurso interno. De acordo com levantamento da Diretoria de Planejamento do INCRA - sede, em torno de $25 \%$ dos funcionários do Instituto irá se aposentar nos próximos 5 anos. Tal projeção é avaliada por seu impacto, pois a proporção aventada afetará grande parte da força de trabalho da SR-27, que foi contratada antes de 1987. A superintendência também tem um alto índice de remoção de servidores. Entre 2006 e 2011 (maio), foram removidos 81 funcionários de Marabá, o que corresponde, aproximadamente, a 30\% da força de trabalho.

As remoções se dão tanto devido a transferências para outras superintendências ou para a sede em Brasília, a pedido do próprio servidor, como também em função de pedidos de exoneração de servidores que passaram em outros concursos. 0 tema das remoções e da falta de servidores é recorrentemente levantado como problema, tal como quase que diariamente ocorria, durante o

37 De acordo com a relação de Projetos de Assentamento atualizada em agosto de 2011, de total de 921.225 família assentadas, 222.465 estão no Estado do Pará (http://incra.gov.br);

38 A SR-27 tem quatro Unidades Avançadas: São Geraldo, Tucuruí, São Félix do Xingu e Conceição do Araguaia. 
trabalho de campo, referente à pesquisa de cujos dados elabora a análise deste artigo. Ele também aparece em entrevistas, reuniões, seminários e em conversas informais com funcionários da superintendência. Os servidores justificam e tentam explicar as causas das remoções de diferentes formas. Como será discutido mais adiante, este é um dos temas levantados na controvérsia que anima os servidores em torno do tema da intervenção política no INCRA.

\section{Estado como Ator-Rede e Mediadores do Incra}

Para compreender como funciona a burocracia do INCRA na SR-27 e como são executadas as políticas de reforma agrária na região, é fundamental trabalhar com a concepção de Estado como um ator-rede, fugindo às artimanhas de pensá-lo como um ator único, coerente e coeso. Como argumentam Passoth e Rowland (2010), o modelo de Estado como um ator se tornou muito útil para pesquisa no campo das relações internacionais e da ciência política. Em que pese sua predominância no campo das ciências sociais, a ideia de que o Estado é um ator unitário foi inicialmente pensada como um pressuposto analítico, uma abstração com valor heurístico. No filosofia política do liberalismo clássico, por exemplo, o Estado foi concebido como um ator que mediaria interesses conflitantes de diferentes grupos. Já no marxismo, a concepção que prevaleceu na Segunda Internacional foi a do Estado como um ator que serve aos interesses da burocracia dominante. Essa concepção de Estado como ator está presente em larga medida nas pesquisas e teorias no campo das ciências sociais. São exemplos as pesquisas que se dedicam a estudar a relação entre sociedade civil e Estado como entidades independentes.

Todavia, conceber o Estado como uma entidade única, cujas ações podem ser estudadas e sistematizadas, pode resultar em análise limitada, que esconde mais do que revela. Com efeito, tal concepção pode impedir que se vislumbrem as diferentes conexões e matrizes complexas formadas por relações entre pessoas, governos de diferentes níveis, partidos, burocratas, movimentos sociais, empresas de assistência técnica, universidades e muitas outras 
unidades articuladas que compõem a matriz do Estado e fazem parte do processo de formulação e execução de políticas. LI (2005) alerta para a complexidade de atores e interesses envolvidos na formulação e implementação de políticas públicas e assinala para os problemas de se trabalhar o Estado a partir de uma concepção monolítica.

Entender o Estado a partir da perspectiva da teoria do ator-rede (LATOUR, 2005) implica explorar as diferentes camadas de relações que o compõem e identificar as associações que diferentes agentes estabelecem entre si. Os agentes que se conectam com outros causando impacto sobre estes ou alterando o estado de coisas anterior são concebidos como mediadores (LATOUR, 2005).

Para efeitos deste artigo, os mediadores podem ser, por exemplo: os próprios burocratas, outras instituições (como o Ministério Público e a Polícia Federal), prefeituras, partidos, lideranças de movimentos sociais, corpo de princípios normativos, processos e formas escritas de comunicação, como os ofícios, além de associações de classe.

Partindo de uma concepção mais ampla, que abarca todo o universo de atores envolvidos nas políticas de reforma agrária, Neves (1999) considera como mediadores todos os agentes intermediários da objetivação do processo de assentamento:

Dirigentes de movimentos sociais de luta pela reforma agrária vinculados ao Movimento dos Sem-Terra, à Confederação Nacional dos Trabalhadores da Agricultura, militantes de partidos políticos, técnicos em agronomia, veterinária, animadores sociais vinculados a programas de ação filiados a instituições estatais - nos seus diversos níveis - ou a organizações não-governamentais (NEVES, 1999, p. 27).

Esses mediadores são portadores de saberes e de capital social e sua mediação é fundamental para a representação dos interesses dos demandantes de políticas de reforma agrária, para a organização dos assentamentos e para a interação com o INCRA. 
Já os mediadores burocratas, ou mediadores profissionalizados, eles tem um papel que vai além da mera execução da política pública mediante o aparato institucional dos programas. Suas ações têm impacto tanto sobre o desenho inicial das políticas, na medida em que as adequam à situação local, como também sobre o beneficiário a quem muitas vezes "ensinam" como o ser, isto é, como beneficiário ideal para determinada política:

Eles articulam fragmentos de significados produzidos em contextos diversos e diferenciados, escutam demandas, apoiam-nas, legitimam ou as condenam. Operam na construção de novos tipos de usuários ou beneficiários, alçados à condição de mediados. Por uma ação de bricolagem, pela acumulação de pequenos detalhes, eles administram acasos e elaboram respostas legítimas à ineficácia institucional e à falta de recursos. (NEVES, 2008, p.30)

Outro elemento importante da ação dos burocratas que atuam na execução das políticas é a discricionariedade (LIPSKY, 1980). Esta é uma característica inerente ao trabalho dos servidores que lidam diretamente com os beneficiários. A necessidade de traduzir e aplicar a política à realidade de cada contexto exige do funcionário habilidade e autonomia para lidar com situações incertas e imprevisíveis que vão surgindo ao longo do exercício de sua função.

o que significa que estes burocratas não apenas estão implementando as políticas, estão, também, fazendo-as. Ou seja, ao agirem com discricionariedade, no momento da operacionalização das políticas, eles de fato estão reconfigurando-as e adaptando-as. O formato final que as políticas tomam, independente do planejamento dos gestores, é também determinado por esta burocracia.

\section{Conexões e controvérsias}

Com o propósito de compreender como as políticas de reforma agrária são executadas pela SR-27, serão a seguir expostas as múltiplas conexões presentes no dia a dia da superintendência e que 
caracterizam o seu funcionamento. Os dados são apresentados a partir da discussão de duas controvérsias centrais observadas no trabalho de campo ${ }^{39}$ e pelas quais perpassam diversos temas em torno dos quais os funcionários se posicionam construindo justificativas para legitimar sua posição. Explorar estas disputas é fundamental porque, ao expor sua posição, os servidores constroem argumentos para justificá-la, trazendo à tona vários elementos que denotam seu ideal de ética profissional, reforma agrária e serviço público.

A primeira controvérsia a ser explorada está relacionada à política no interior da SR, que se traduz na disputa relativa ao caráter político da Autarquia. A segunda controvérsia abarca a relação dos agentes institucionais com os movimentos sociais. Ela está explícita na disputa sobre como deveria ser o trabalho do INCRA e como ele se dá na prática. A controvérsia em torno da política dentro da SR e a controvérsia em torno da relação da SR com os movimentos sociais estão interligadas e é possível se ver as mesmas formas de justificação em ambas sendo utilizadas.

O objetivo da exposição dessas controvérsias é apresentar dados que qualifiquem as conexões e mediações que fazem parte do trabalho dos servidores do INCRA e que permitam observar mais aproximativamente a complexidade envolvida na execução das políticas de reforma agrária. Também objetiva-se propor uma explicação mais interativa sobre a relação entre os servidores do INCRA e os representantes dos movimentos sociais, especialmente relações que transcendem o modelo de interpretação que articula Estado e sociedade civil como atores coerentes e unitários. Um exemplo deste tipo de interpretação é a análise de Wolford (2010), que tenta compreender o processo de participação dos movimentos sociais no INCRA a partir da literatura sobre democracia participativa.

39 Latour (2005) e Boltanski (2007) assinalam que disputas e controvérsias são momentos privilegiados de análise uma vez que neles os diferentes atores expressam e justificam suas posições de forma mais clara e detalhada. 


\section{O Incra e a Política}

No dia 14 de outubro de 2011, foi realizado, no auditório da Câmara Municipal de Marabá, um seminário que reuniu todos os funcionários da SR-27 e das quatro Unidades Avançadas. O objetivo do seminário era apresentar a todos os servidores o projeto, que está sendo levado a cabo pela SR, de execução da política de universalização de assistência técnica (ATES) ${ }^{40}$ para todos os assentamentos na jurisdição da SR-27. A direção da SR recomendou que não houvesse expediente da superintendência naquele dia, devido ao seminário e para que assim todos os funcionários comparecessem ao evento, tanto que o evento foi amplamente divulgado. Para os funcionários das Unidades Avançadas que foram ao evento, foi pago o valor de uma diária para se deslocar até Marabá. Este foi o primeiro evento que reuniu toda a força de trabalho da SR e das Unidades Avançadas. Antes de começar o seminário, cada pessoa se apresentou dizendo rapidamente seu nome e uma frase. Alguns servidores das Unidades Avançadas agradeceram por terem sido convidados. Esses agradecimentos estão relacionados aos comentários frequentes em reuniões e pelos corredores da SR, dando conta de que os servidores das Unidades Avançadas sempre são esquecidos.

Após as apresentações, uma servidora se levantou e pediu para ler um trecho da Bíblia para reflexão, antes de serem iniciados os trabalhos. Em torno de 20\% a 30\% dos servidores da SR são evangélicos e toda semana é realizada uma reunião para oração e reflexão no auditório da superintendência. Após a leitura da Bíblia, a servidora esclareceu que tinha escolhido um trecho que achava que se relacionava com o momento que estavam vivendo lá na SR:

A gente vê muita picuinha no INCRA, coisa pequena que interfere à nossa volta. Tanta crítica que ouvi nos corredores em relação a este

40 O INCRA adota, desde 2004, o programa de Assessoria Técnica, Social e Ambiental à Reforma Agrária (ATES). A ATES é uma forma de Assistência Técnica e Extensão Rural (ATER) qualificada para o público de reforma agrária. 
evento de hoje, o que não tem sentido, pois tem 3 anos que estamos preparando a universalização da ATES (...), nós somos servidores dos assentados, dos agricultores (Servidora SR: Seminário em Marabá, 14-10-2001).

Na segunda sessão do seminário, após a apresentação do coordenador nacional da política de ATES, teve início uma rodada de perguntas e comentários sobre a exposição. Os quatro primeiros comentários mencionam os desvios de dinheiro e as "falcatruas" que já ocorreram no programa de ATES na SR no passado. Levantaram temas como a dificuldade de fiscalizar o cumprimento dos convênios devido à falta de servidores. Algumas falas apresentam a proposta de aplicar a política apenas para alguns assentamentos, uma vez que seria mais fácil a fiscalização. Em uma de suas falas, um servidor que se apresenta dizendo que está agora na presidência da Associação (ASSERA Sul do Pará - Associação de Servidores da Reforma Agrária do Sul do Pará) ${ }^{41}$, e por isso exercendo esse papel mais crítico, menciona que a falta de servidores é um problema grave na SR e que, mesmo assim, foram autorizadas mais de 80 remoções nos últimos anos, bastando-se ser filiado ao PT para conseguir uma remoção para Brasília e para outros lugares. Em compensação, quem não fosse filiado ao PT não conseguia remoção. $O$ tema das remoções relacionadas à política, ou "remoções por politicagem" na palavra de alguns servidores, também foi levantado em algumas entrevistas.

Nesse momento, e na medida em que muitos servidores se manifestaram diante do comentário sobre o PT, aplaudindo ao final de cada uma dessas intervenções, torna-se explícita e pública a controvérsia existente na SR em torno da relação entre a política

41 A Assera Sul do Pará, em Marabá, assim como as outras Assera ou Assincra (Associação de Servidores do INCRA) nos demais estados, é representada nacionalmente pela CNASI (Confederação Nacional dos Servidores do INCRA). Outra associação de classe do INCRA é a Assinagro (Associação Nacional dos Engenheiros Agrônomos do INCRA) que representa a carreira dos Peritos Federais Agrários, engenheiros agrônomos. 
partidária do PT e o INCRA. Na fala pública citada anteriormente, estabelece-se uma relação entre a filiação do PT e o não tratamento igualitário para todos os servidores do INCRA, diante do pedido de remoção. Nesse caso, a ordem de grandeza acionada pelo servidor e a partir da qual se contrasta a ação da direção é a de que um tratamento particularista, devido à filiação a um partido, é condenável.

Alguns dias após o seminário foi realizada uma entrevista com este servidor, presidente da ASSERA Sul do Pará. Ele comenta que há um problema de gestão na SR: "muitos vem mais para fazer daqui um trampolim político, para daqui sair para ser candidato a deputado, essas coisas, não tem compromisso com a entidade e com os profissionais".

Nesse caso, a vinculação da direção do INCRA com a política partidária é questionada, acionando-se o argumento de que isso seria contrário ao compromisso com a entidade e com os servidores.

A visão de que deveria haver uma separação entre o INCRA e a política partidária fica ainda mais clara na seguinte formulação:

Porque uma coisa, por exemplo, nós vivemos num país democrático, nós temos direito de ter filiação partidária. Mas uma coisa é você separar qual é sua atuação enquanto dirigente partidário, enquanto partido e enquanto dirigente de uma entidade pública federal e muitas vezes isso não tem muita... traz problema. (Presidente da ASSERA/PA, 2011).

A menção à relação do INCRA com o partido como uma coisa estranha ou condenável aparece também em algumas outras conversas informais e entrevistas com servidores. Um exemplo é a utilização de expressões como "aqui é tudo politicagem”, "a política às vezes atrapalha", "aqui tem um grupo político que manda”, "os chefões políticos que mandam".

Nessa controvérsia em torno da presença da política partidária no INCRA, existem também outras posições, que talvez possam ser entendidas como mais moderadas. Neste caso, os servidores compreendem que o INCRA é por natureza um órgão político e composto politicamente, mas, a despeito disso, eles recebem um 
salário e têm que fazer seu trabalho. Os funcionários que defendem essa posição argumentam que os servidores que só criticam e são contra a direção política do INCRA estariam atrapalhando o trabalho da SR, na medida em que se recusam a fazer qualquer coisa que possa ajudar ou favorecer o grupo político dominante; e, em consequência, quem sofre é o agricultor assentado. Nesse caso, a justificativa se constrói em torno do papel que o INCRA tem de atender aos agricultores assentados e a falha em realizar este papel é atribuída às discordâncias políticas, prática considerada condenável.

É necessário voltar um pouco para se compreender as conexões que são alvo da disputa e estariam situadas no outro polo da controvérsia. De acordo com o ordenamento do Poder Executivo, até $30 \%$ das posições podem ser ocupadas por cargos de confiança. No caso do INCRA, essas funções normalmente são ocupadas por indicação política e pode-se pensar que isso garante, de certa forma, que a autarquia irá seguir a linha política estabelecida pelo governo ${ }^{42}$.

As indicações para os cargos comissionados se dão de acordo com a composição política de cada região. No caso do Pará, de acordo com a correlação de forças políticas, as indicações das superintendências estão divididas da seguinte forma: Santarém (PMDB), Belém (PT) e Marabá (PT). No caso da SR-27, as indicações estão a cargo do grupo político, de situação mais forte da região: uma tendência regional do PT denominada "PT pra valer". As expressões mais fortes desta tendência na região são: o Deputado Federal Zé Geraldo e a Deputada Estadual Bernadete Ten Caten ${ }^{43}$.

Atualmente, os cargos indicados politicamente na SR-27 são o de ouvidor agrário, que atualmente é exercido por um ex-vereador do PT, o de Chefe de Gabinete, exercido por uma liderança política

42 Formalmente são nomeados pelo Presidente da República, por indicação do Ministro de Desenvolvimento Agrário, os cargos de: Presidente, o Diretor de Programa, os Diretores, o Superintendente Nacional de Regularização Fundiária na Amazônia Legal e o Procurador-Chefe.

43 Foi superintendente do INCRA entre 2004 e 2006. Elegeu-se para o primeiro mandato de Deputada Estadual em 2006 e está agora em seu segundo mandato. 
fundadora do PT na região ${ }^{44}$, o próprio superintendente, ligado ao MST e formado pelo Pronera, além dos chefes de duas das quatro unidades avançadas.

Todas essas conexões denotam que a dimensão política do INCRA não se configura como um desvio, mas como norma, não só na SR-27 como em todas as regionais. A evidência é o próprio regimento interno que prevê cargos de confiança, os quais podem ser preenchidos por indicação política. Além da lógica de atribuição de cargos na Autarquia, que por si só assinala para a função política que o INCRA assume - haja vista o grande número de ex-superintendentes que se candidataram a cargos políticos nos últimos anos em todo o Brasil, há outra dimensão de articulação política inerente ao instituto. De acordo com a legislação que rege as políticas de reforma agrária, o INCRA deve fazer convênio com as prefeituras locais dos municípios onde estão localizados os assentamentos para a realização de obras de infraestrutura, como estradas vicinais e pontes. Por meio desses convênios, o INCRA repassa um dinheiro para as prefeituras para que elas realizem as obras.

Os servidores que se posicionam contra a intervenção político - partidária no INCRA, justificam sua posição a partir da apresentação de uma visão específica de Estado, que se aproxima bastante da discutida anteriormente. Com efeito, a ordem de grandeza utilizada para condenar a intervenção política no INCRA denota uma concepção de Estado como entidade idealmente autônoma, neutra e racional. Da mesma forma, o modelo de burocrata entendido como legítimo é o de um funcionário de certa forma insulado e imparcial, na medida em que não deve se deixar influenciar por suas posições ideológicas ou de seus valores no exercício de sua função.

Do ponto de vista da análise sociológica e política, é mais prudente pensar que as instituições estatais são formadas por pessoas, que se relacionam em redes políticas e sociais, que têm valores e ideologias que influenciam seu trabalho, assim como influenciam os demais aspetos de sua vida. Uma visão do Estado como uma

44 Saiu do INCRA em março de 2012 para concorrer às eleições para a prefeitura de Marabá. Foi substituído por uma servidora "da casa". 
entidade isonômica, à qual, todos deveriam ter acesso igualitário, a partir de princípios universais, embora palatável ao discurso político, contribuiria para uma análise sociológica ingênua e incompleta.

Essa controvérsia em torno da dimensão político-partidária do INCRA adquire um lugar relevante na superintendência, na medida em que pode levar a divisões internas e oposição à direção por parte dos servidores. Um exemplo disso foi a publicação, no Jornal da ASSERA Sul do Pará, de junho de 2011, da informação de que o atual superintendente foi beneficiário da reforma agrária e teria vendido o lote. A notícia termina com a seguinte pergunta: "Qual a moral que o Superintendente tem para mandar fiscalizar lotes, se ele mesmo está irregular, pois vendeu o lote sem anuência do INCRA?" (ASSERA Sul do Pará, Boletim Informativo n. 003, junho, 2011).

Novamente a ordem de grandeza evidenciada é a moral do servidor público. Essa controvérsia também tem implicação para a execução das políticas públicas, uma vez que os servidores podem se recusar ou podem deliberadamente atrasar o cumprimento de determinada tarefa. Um evento que exemplifica o impacto da controvérsia na execução da política foi a denúncia feita por alguns servidores da SR ao Ministério Púbico, de que uma terra para desapropriação teria sido superavaliada com o propósito de direcionar o dinheiro para a campanha de um ex-superintendente da SR. Essa denúncia foi feita no ano eleitoral e, depois de uma investigação, concluiu-se que ela era falsa. Com isso, atrasou-se o processo de desapropriação por mais de um ano.

Algumas conexões explicitadas ao longo da exposição da controvérsia acima são importantes para se compreender o funcionamento da SR-27, dentre elas: a conexão com o PT, com a Assera, com as prefeituras, com o Ministério Público e com o INCRA - sede em Brasília. Estas são algumas das conexões mediadas pelos servidores da SR-27. A análise de como são executadas as políticas públicas pressupõe então o conhecimento dessas conexões e de seus efeitos. 


\section{O Incra e os movimentos sociais}

A controvérsia no interior da SR-27 em torno da relação com os movimentos sociais se dá em diferentes níveis e assume diferentes formas, uma vez que o INCRA se relaciona com os movimentos sociais em contextos distintos. O que aparece nessa controvérsia como problema central, associado à ação dos movimentos, é o descompasso entre como deveria ser o trabalho do INCRA no momento da criação do assentamento e como ele acaba sendo feito na prática. O instituto deveria ter o trabalho de identificar uma área e levar a cabo todo o processo de desapropriação ou obtenção daquela área. Uma vez conseguida a área, os servidores do INCRA deveriam fazer um levantamento apropriado do território, com topografia, geoprocessamento e levantamento técnico. Com esses dados em mãos e de acordo com os critérios do tamanho do módulo fiscal, seriam demarcados os lotes e selecionadas as famílias (o INCRA as selecionaria). Depois de tudo isso, é que as famílias ocupariam a área e entrariam na Relação de Beneficiários.

Contudo, na prática, isso não é o que acontece. Quando o INCRA integra a demanda ou começa a colocar, em prática, os procedimentos, os movimentos já estão ocupando a área, as famílias já estão cada uma em seu lote, normalmente não se respeitando os limites estabelecidos pelo INCRA, havendo situações em que se colocam duas ou mais famílias em um lote que caberia apenas uma. Esse exemplo é citado por alguns funcionários para argumentar que o INCRA não está fazendo o que deveria fazer e que sua atuação tem se limitado apenas a apagar fogo. A menção ao fato de que o INCRA chega a uma área e ela já está toda ocupada, foi feita várias vezes durante o seminário sobre universalização de ATES, para argumentar que seria difícil executar assistência técnica dessa forma, sem planejamento e sem que o INCRA tenha controle e informação sobre os assentamentos. Nesse sentido, os movimentos sociais estariam atropelando o trabalho do INCRA. Este argumento de atropelamento também é levantado por muitos servidores, quando perguntados como avaliavam a relação entre a SR-27 e os movimentos sociais. 
Se, por um lado, alguns servidores fazem a associação com a ação dos movimentos sociais para afirmar que o trabalho do INCRA não está sendo feito da maneira como deveria ser feito, por outro, outros servidores associam a ação dos movimentos a uma melhora na situação da superintendência ou à própria existência do INCRA. Alguns relatos reproduzem a afirmação do antigo presidente do INCRA que os movimentos sociais são parceiros do Instituto, sem eles, provavelmente o INCRA nem existiria mais.

As afirmações que associam as ações dos movimentos sociais a uma melhoria da situação orçamentária da SR-27 se referem à ocupação do INCRA por 44 dias em junho de 2011. A ação foi organizada pelos três principais movimentos sociais da região: FETAGRI, MST e FETRAF. Os porta-vozes dos movimentos apresentaram uma pauta que incluía, dentre outros temas, a universalização da política de ATES. Após 44 dias, o presidente do INCRA foi a Marabá e negociou com lideranças a liberação de 40 milhões para a execução da política de ATES em Marabá, além de garantir fundos especiais para a desapropriação de algumas áreas.

Em conversas informais e entrevistas, os servidores expressaram suas percepções sobre esta ocupação de maneiras muito diferentes. Tanto o superintendente quanto os chefes da Divisão de Obtenção e da Divisão de Desenvolvimento associaram a relação da SR-27 com os movimentos sociais ao aumento do orçamento para a superintendência e à universalização da política de ATES. Durante a apresentação no seminário, uma das servidoras encarregada de formular a chamada pública para a contratação de entidades, começou sua apresentação dizendo: "todos nós sabemos que não fosse pelos movimentos sociais nós não estaríamos aqui hoje universalizando a política de ATES”. Por essa conclusão, ela justificava o título de sua apresentação: "Universalização de ATES: uma conquista dos movimentos sociais".

Também durante o seminário, em resposta às afirmações de alguns servidores referentes à falta de controle do INCRA sobre os assentamentos e a consequente incapacidade de universalizar a política de ATES para todos os assentamentos, o Chefe de Gabinete diz: "Não está mais no nosso escopo decidir sobre a dimensão da 
política, isso foi um acordo dos movimentos sociais com o Ministro, já está acima de nós. Cabe-nos agora executar a política".

Essas duas posições expressas, no seminário e nas entrevistas, demonstram que há uma controvérsia em relação ao papel dos movimentos sociais, especialmente no que tange à ingerência que eles têm no INCRA. Ao que parece, os dois lados utilizam grandezas distintas na avaliação das ações dos movimentos sociais. De um lado, há um grupo de servidores que reconhece, de forma geral, o papel dos movimentos sociais como positivo ao considerá-los agentes protagonistas que reivindicam, com sucesso, recursos e condições para a realização das políticas de reforma agrária. Neste caso, os servidores assinalam que eles buscam manter uma relação de parceria com os movimentos sociais.

Por outro lado, há um grupo de servidores que ressalta predominantemente o aspecto negativo da ação dos movimentos sociais, destacando que muitas vezes seu trabalho é atropelado ou ignorado em consequência de acordos fechados entre chefia e movimentos sociais. Na argumentação destes servidores, aparece uma sobreposição com a controvérsia anterior. Grande parte das lideranças dos movimentos sociais tem proximidade política e, em alguns casos, vínculos partidários com o grupo político dominante na SR. No caso dos servidores que avaliam a relação entre INCRA e movimentos sociais nessa chave aparece a menção ao caráter "promíscuo" da relação, notadamente no que diz respeito aos convênios de ATES e à relação com o partido e com campanhas eleitorais.

Ainda referente a essa controvérsia, cabe dizer que há muitos outros momentos nos quais os servidores do INCRA se relacionam com os militantes dos movimentos sociais. Tão diversos como são estes momentos, são também as posições, valores, opinião política e interesses dos servidores que interagem com tais agentes dos movimentos sociais.

As relações estabelecidas entre INCRA e movimentos sociais, ainda no momento em que os trabalhadores estão acampados, são operacionalizadas principalmente por meio da ouvidoria agrária e envolvem a concessão de cestas básicas, para a qual os funcionários da ouvidoria seguem normativa do programa Fome Zero, além da concessão de lona preta pelo INCRA. As conexões com lideranças de 
acampamentos também se dão no âmbito da Comissão de Combate ao Conflito no Campo, que se reúne na SR-27 aproximadamente todo mês, com o propósito de tentar encaminhar soluções para áreas ocupadas ou em conflito.

Outra importante conexão entre o INCRA e os movimentos sociais se dá por meio das relações com presidentes de associação de assentados. Esses presidentes, no mais das vezes, estão ligados a sindicatos ou a outros movimentos e operam a representação dos trabalhadores. As associações, por meio de seus presidentes, são interlocutoras reconhecidas e legítimas para dialogar com os porta-vozes do INCRA. Não só no momento em que vão à superintendência para reivindicar liberação de créditos, titulação de terras e construção de estradas, como também quando agem como mediadores reconhecidos legalmente para deliberar e autorizar a construção de casas por meio de conta conjunta com o INCRA.

Os presidentes de associação, presidentes de sindicatos e lideranças de movimentos vão ao INCRA com frequência e conversam com diferentes servidores em momentos distintos. As lideranças mais importantes se reúnem com o superintendente, mas todos os outros setores do INCRA também recebem e atendem pessoas diariamente.

Os servidores do INCRA, com toda sua variedade de opiniões políticas, valores, ideias e comportamentos, também vão a campo para fazer vistoria e outros tipos de trabalho. Nesse momento, interagem com presidentes de associação, que têm pleno conhecimento do emaranhado de funções exercidas pelos funcionários do INCRA e da diversidade entre eles, e fazem, muitas vezes, uso estratégico dessa diversidade quando ela pode ser avaliada por efeitos contraditórios.

Tentou-se mostrar a partir da controvérsia em torno da relação entre a SR-27 e os movimentos sociais a miríade de associações e conexões que se estabelecem entre os burocratas e os movimentos sociais. Também buscou-se demonstrar que não há possibilidade de se explicar, de maneira esquemática, a relação entre a SR-27 e os porta-vozes dos movimentos sociais, uma vez que há não só inúmeros pontos de conexão como também um grande espectro de posicionamentos possíveis por parte dos servidores. 


\section{Considerações Finais}

Por este artigo, busquei contribuir com as reflexões em torno da compreensão do Estado como um ator-rede, levando em conta a apresentação de dados empíricos obtidos por pesquisa colocada em prática junto ao INCRA de Marabá. Um dos argumentos que se buscou tecer é o de que a compreensão do Estado a partir do modelo do ator unitário não dá conta de apreender toda a dinâmica envolvida no processo de implementação de políticas públicas, uma vez que não permite a explicitação das redes e conexões presentes ao longo do processo.

Busquei ainda mostrar, mediante análise de certas controvérsias que permeiam as relações entre os funcionários do INCRA, os meandros da ação institucional, na medida em que considero que, apenas a partir de uma análise dessas relações, é possível tentar compreender como a superintendência regional funciona. Nesse sentido, cabe contestar, a partir dos dados de pesquisa apresentados, algumas interpretação de Wolford (2010) em seu estudo sobre o INCRA. Primeiramente, a autora separa analiticamente duas instâncias que na prática estão ligadas em múltiplos níveis - o MST está presente na formulação da política pública assim com o INCRA está presente na organização do movimento, quando nada em alguns momentos, para melhor adequá-lo à política pública. Desconsiderar esses aspectos pode levar a uma compreensão incompleta da relação entre os dois. Por essa razão, o modelo que concebe Estado e sociedade civil como entes separados não é adequado para este caso. E em segundo lugar, a tentativa de interpretar a relação como uma experiência de democracia participativa pode induzir a erros, uma vez que o INCRA reconhece a participação de movimentos sociais apenas por meio de seus dirigentes, seguindo o princípio de representação delegada. Não se configura, em momento algum, uma esfera deliberativa na qual, indivíduos autônomos e simétricos possam participar de forma igualitária, tal como a idealização democrática apregoa. 


\section{Referências}

ASSERA SUL DO PARÁ. Boletim Informativo n. 003. Julho de 2011. CNASI. Disponível em: http://www.cnasi.org.br/index.php?option=com_content\&view=category\&layout=blog\&id=1\&Itemid=34

ASSIS, William. Mobilização camponesa no sudeste paraense e luta pela reforma agrária. In: MEDEIROS, L.; FERNANDES, B. Lutas camponesas contemporâneas: condições, dilemas e conquistas. São Paulo: Unesp, 2009.

BOLTANSKI; L; THEVENOT, L. A sociologia da capacidade crítica. Antropolítica n. 23. Niterói, 2007.

INCRA. Relatório de Atividades: INCRA 30 anos. Brasília: Gráfica Guarany, 2000.

LATOUR, Bruno. Reassembling the social: an introduction to actornetwork-theory. Oxford: University Press, 2005.

LIPSKY, Michael. Street-level Bureaucracy. Dilemmas of the indiviadual in the public service. Nova Yorque: Russel Sage Foundation, 1980.

LI, Tania. Beyond 'the State' and Failed Squemes. American Antrophologist. Oxford: University Press, v. 107, Issue 3, p.383-394, 2005.

NEVES, Delma Peçanha (Org.). Desenvolvimento social e mediadores políticos. Porto Alegre/Brasília: Editora da UFRGS/PGDR/NEAD, v. 1, p.174, 2008.

NEVES, Delma Peçanha. Assentamento rural: confluência de formas de inserção social. Revista Estudos Sociedade e Agricultura, n.13, p.5-28, outubro 1999. 
PASSOTH, J.; ROWLAND, N. Actor-Network State : Integrating ActorNetwork Theory and State Theory. International Sociology, p., 2010.

WOLFORD, Wendy. Participatory democracy by default: land reform, social movements and the state in Brazil. The Journal of Peasant Studies, v. 37, n. 1, p.91-109, Jan. 2010. 
Parte 2 



\section{Modos de Objetivação de Programas Públicos: o PAA em foco}

Ramonildes Gomes

As referências às políticas públicas fazem parte da nossa vida cotidiana. Afinal, o nosso comportamento individual é em grande parte influenciado e, em muitos casos, relativamente determinado por princípios instituídos em políticas públicas. À guisa de exemplo: nossa alimentação depende de políticas agrícolas, ambientais e sanitárias; nosso lazer, das políticas voltadas ao turismo e à realimentação de práticas culturais estrito senso. Por sua vez, todas as políticas tendem a um processo de articulação que envolve atores, projetos, instituições, marcos regulatórios, descobertas científicas e desafios postos pela sociedade.

Destarte, as ações, programas e projetos sintetizados como políticas públicas, os estudos de casos apresentados na parte II dessa coletânea revelam, através de incursões em espaços geográficos diferentes, como as ações de intervenção pública e social planejadas interferem na vida dos indivíduos controlando suas condutas e imprimindo novas racionalidades, as quais, segundo os objetivos e metas, adquirem diferentes denominações, a saber: política de desenvolvimento territorial, de construção de infraestrutura, de saúde, de habitação, de segurança alimentar, de crédito, de assistência técnica entre outras. A atividade profissional dos cientistas que analisam a vida social se inscreve fortemente nos quadros de 
delimitação dessas políticas públicas, especialmente as que visam dotar os cidadãos de recursos para produção, ou consumo de conhecimentos coletivamente elaborados, dos benefícios que eles podem aportar. Participamos nesses quadros de definição da vida social como atores, produtores de conhecimento, ou mediadores na circulação de ideias. Mediante a crítica metodológica, contribuímos para elevar a qualidade de corpos conceituais e dos procedimentos metodológicos de produção de conhecimentos, pautados em situações empíricas e em desafios concretos.

Somos todos atores sociais confrontados permanentemente pela produção de ideários e regulamentações, no caso aqui valorizados, no centro dos espaços de definição das chamadas políticas públicas: - tanto como destinatários, mas também corresponsáveis pela elaboração de agendas. Portanto, por engajamentos coletivos, nós todos temos responsabilidades sobre o reconhecimento político de problemas sociais. Por esse estatuto de reconhecimento, mas também como de demandas que vão, afinal, pautar a definição e as condições de oferta de recursos e serviços públicos, enfim, da reordenação da sociabilidade dos indivíduos.

$\mathrm{Na}$ condição de cientistas sociais, raramente ocupamos lugares de decisão, mas é certo que desempenhamos papel importante, como avaliadores ou pressupostos experts, qualificando e requalificando o debate político e acadêmico sobre as políticas públicas. A extensa presença dos cientistas em diferentes domínios da vida social vem se traduzindo na multiplicação dos trabalhos de pesquisa, facilmente comprováveis pela profusão de livros e coletâneas que, nas últimas décadas, vem sendo editadas; provimento que vem sendo acompanhado pela criação de revistas temáticas, de programas de pós-graduação e uma infinidade de eventos acadêmicos que tem como foco o debate das políticas públicas.

Dentre esses investimentos intelectuais, destacamos a importância de textos voltados para a análise de cunho mais teórico e metodológico sobre políticas públicas. Por esse prisma, os autores buscam compreender o papel do Estado, particularmente as mutações ocorridas na forma contemporânea, dimensão imediatamente verificável nos títulos do corpo bibliográfico de outros 
tantos autores que se associam àquele investimento. Tal é o caso de consagrados autores como: Jobert e Muller, 1987; Sardan, J-P, 1995; Amartya Kumar Sen, 2000; Gilbert Rist, 1996. A imersão nessas leituras permite afirmar que algumas delas buscam uma compreensão do Estado pelos resultados acumulados nas diferentes experiências de intervenção, tal como vieram a caracterizar as formas mais recentes de operação prática do Estado como instância executiva, que dispõe de aparato legal e administrativo. E, no Brasil, essas mesmas referências povoam os debates em torno da compreensão de diversos programas públicos, notadamente, para o segmento dos agricultores que aqui privilegiamos, o PRONAF(Programa Nacional de Fortalecimento da Agricultura Familiar), o PAA (Programa de Aquisição de Alimentos), o PNAE (Programa Nacional de Alimentação Escolar), o Programa do Leite, o P1MC (Programa Um Milhão de Cisternas). Da mesma forma, em diversas experiências de constituição dos assentamentos de reforma agrária, programa que, em complementaridade e sintonia com novas demandas, vai agregando tantos outros: a Cédula do Produtor Rural, PINGATI (Política Nacional de Gestão Territorial e Ambiental em Terras Indígenas) etc. Mas não só, também registramos investimentos de pesquisa em textos que enfrentam as dimensões teóricas e metodológicas e as conexões dessas com a conceituação do Estado, analisando como os conceitos são metamorfoseados pelos tentáculos institucionais que o Estado assume a saber: do INCRA (Instituto Nacional de Colonização e Reforma Agrária), da EMATER (Empresa de Assistência Técnica e Extensão Rural), do ITESP (Instituto de Terras do Estado de São Paulo), entre outros e em diferentes regiões do Brasil.

O escopo do espaço social em jogo, melhor compreensível pela significativa metáfora da arena, é contingente e inerente à definição de política pública; mas desde que aceitemos por 'público' o espaço central do Estado, neste caso, por oposição à esfera privada, que remete às relações interindividuais, ou seja, em princípio sem a intervenção do Estado (HASSENTEUFEL, 2008, p.8).

As inúmeras dimensões que se colocam em disputa no estudo de políticas públicas podem ser identificadas em experiências como a 
que propõe Manuel Pereira do Nascimento Neto ao discutir a efetividade do PAA no município de Lagoa Seca no agreste paraibano, em que pese o fato de ser este um município que possui aproximadamente 1.592 estabelecimentos familiares e apenas 35 destes têm conseguido participar do Programa de Aquisição de Alimentos. Contudo, nem sempre essa participação que é delegada às associações esclarece os objetivos, as interdependências, a multiplicidade de interesses dos grupos envolvidos e de pressão, também não esclarece sobre a qualidade da participação, em particular na interação com o Estado e com os mediadores. $\mathrm{O}$ artigo de Manuel Pereira do Nascimento Neto apresenta uma descrição do PAA, no curso de 09 anos de presença do Programa na região, dando visibilidade ao modo de organização e as formas de enquadramento dos comportamentos coletivos dos agricultores familiares, particularmente identificados nas mudanças ocorridas na dinâmica econômica das propriedades e no processo de comercialização dos produtos.

Não sem razão, no centro do que se convencionou reconhecer como campo temático de estudo e proposições de políticas públicas, contribuem autores que investem na visibilidade social de sujeitos pressupostamente, mas não muito adequados, posicionados do outro lado do ringue, ou seja, no espaço da contraposta sociedade civil. São eles: ONGs- Organizações Não-Governamentais e Movimentos Sociais, esses atores coletivos, atuando estrategicamente em rede, ou adotando formatos outros agem como porta-vozes, procuram reforçar e ressignificar os vínculos de agregação e afiliação de segmentos a serem engajados ou atingidos. No caso em tela, privilegiamos o artigo de Jaqueline da Luz Ferreira e Patrícia dos Santos Pinheiro, as quais analisam a experiência do MOC (Movimento de Organizações Comunitárias), o papel que esta ONG desempenha na organização e articulação dos agricultores familiares na Região Sisaleira, localizada no semiárido baiano, com objetivo de inserir os agricultores no complexo processo de operacionalização do Programa de Aquisição de Alimentos. O investimento feito pelo MOC implicou na reestruturação de cooperativas e associações formadas nas décadas anteriores, mas que estavam imobilizadas em função da falta de estímulo e de oportunidades capazes de 
assegurar certa regularidade ao seu funcionamento, de agregar e manter ativos grupos com interesses diversos.

Adotar o olhar metodológico ou disciplinar fundamentado na metafórica concepção de arena, em tese pressupõe o desafio assumido por pesquisadores na tarefa de compreender situações a priori definidas como contraditórias: - manter uma posição de independência intelectual, não permitindo que o alinhamento ideológico distorça aquilo que seria próprio da ciência, mapear e analisar evidências empíricas, que demonstrem os processos em disputa; e fazer que, de fato, as evidências empíricas possibilitem refletir sobre a prática da ação pública, a partir dos jogos e tensões que não podem ser esquecidos, porque atravessam os espaços de definição e demanda por políticas públicas. A postura e a prática dos ADRS (Agente de Desenvolvimento Rural Sustentável) enquanto um mediador social qualificado tal como analisado por Valdênio Meneses e Ramonildes Gomes ao imergir no processo de estimulo à produção de leite de cabra entre agricultores familiares no Cariri Paraibano. Os autores, que através de uma dimensão cognitiva das políticas públicas orientada para a mediação, constatam que os ADRS vivenciam conflitos, cujas contradições geradoras destes se expressam nos referenciais de conhecimento que legitimam os projetos de desenvolvimento. A condição de mediador transforma os atores/mediadores em "mensageiros" de inovações e de estratégias, cujo objetivo é impulsionar o crescimento da atividade pecuária. Contudo, o processo de mediação dos ADRS se capilariza por referenciais cognitivos conflitantes, a partir de um diálogo entre racionalidades técnicas e formas de conhecimento dos agricultores familiares que são o alvo dos projetos do Sebrae-PB, das políticas ministerias e das institucionalidades mais locais.

Para atravessarmos esse mar de produção e redefinição conceitual de políticas públicas, alertamos aos leitores que estamos nos valendo nessa parte da coletânea de uma definição do conjunto normativo tido como políticas públicas, incorporando contribuições de Pierre Muller (2000) assim postuladas: “cada política corresponde a uma parte da idéia aceita do problema (...) de um grupo social representado, ou de um setor que pelo domínio de 
um conhecimento a faz existir (...) e de uma teoria de mudança social" Também advertimos que o conjunto das experiências empíricas que ilustram o debate, segundo a compreensão dos autores de artigos aqui perfilados, foi valorizada por direta ou indiretamente adotarem perspectiva processual, coerentemente ao estudo do amplo espectro de questões que estão abarcadas pelo termo políticas públicas. Grosso modo, podem ser aproximadas às concepções defendidas por Nobert Elias, dado que, longe de obedecerem a noções definidas a priori, os sentidos e objetivos a serem compreendidos são aqueles atribuídos pelos indivíduos no próprio curso da ação pertinente.

Pretendemos com os textos dessa coletânea demonstrar que a formulação de políticas públicas mobiliza segmentos da instituição estatal e da articulada organização metaforicamente qualificada sociedade civil, tendo no centro dessa mobilização recursos e capitais diversos; ou seja, concorrência de saberes e conhecimento técnico. A luta social inerente à definição de sentidos e procedimentos da relativa a objetivação de políticas públicas já pressupõe redefinições, mobilizações e desmobilizações, afirmação criativa e negação de estratégias e práticas insistentemente legitimadas. Em contraposição, desqualificações dos sentidos projetados por grupos sociais que as negam ou minimizam a importância. Correlativamente, a preocupação analítica deve incidir sobre processos sociais que emergem nos espaços aos quais se atribuem legitimidade e legalidade para instaurar definição e redefinição do estatuto globalizante de políticas públicas. 


\title{
V
}

\section{Diferenciações entre agricultores familiares em Lagoa Seca: PAA, Mercados Institucionais e Desenvolvimento Rural}

\author{
Manuel Pereira do Nascimento Neto ${ }^{45}$
}

\section{Introdução}

O Sr. Manoel Inácio, 49 anos, presidente da associação de agricultores dos Sítios Jucá e Boa Vista, é muito conhecido no município de Lagoa Seca (PB) e uma das mais ativas lideranças rurais da região. Quinzenalmente, depois de carregar sua caminhoneta com banana pacovan, tangerina, batata doce, macaxeira, entre outros produtos cultivados em suas terras, passa nas propriedades de agricultores da vizinhança recolhendo outros produtos agrícolas que serão levados ao ginásio esportivo Santino Herculano de Lima, popularmente conhecido como O Santinão. No local, dois técnicos agrícolas, uma nutricionista e mais dois ou três funcionários da prefeitura local recebem os alimentos trazidos por Seu Manoel e cuidam para que sejam distribuídos em 15 escolas municipais, duas creches, no Hospital Municipal Ana Maria Coutinho e no Lar da Sagrada Face, um asilo de idosos.

45 Licenciado em geografia pela UEPB, especialista em Agroecologia e Educação de Jovens e Adultos pela UFPB e mestrando em Desenvolvimento Regional pela UEPB/UFCG. manuelpereiraneto@hotmail.com 
Seu Manoel é um dos 35 agricultores de Lagoa Seca vinculados, em 2011, ao Programa de Aquisição de Alimentos (PAA), coordenado em nível nacional pelos ministérios do Desenvolvimento Social e Combate à Fome (MDS) e do Desenvolvimento Agrário (MDA) e gerido, localmente, pela Secretaria de Agricultura do município. O ginásio O Santinão funciona como centro de recebimento e distribuição dos produtos adquiridos diretamente dos agricultores habilitados pelo PAA no município. Os funcionários da Prefeitura que se deslocam para o ginásio em dias previamente acordados para receber os alimentos e destiná-los às instituições previamente aprovadas pelo Conselho Municipal de Desenvolvimento Rural Sustentável (CMDRS) receberam treinamento da Companhia Nacional de Abastecimento (CONAB), através de seu escritório em João Pessoa, que coordena o PAA na Paraíba.

O PAA integra o conjunto de ações do Programa FOME ZERO e incide em um mecanismo complementar ao PRONAF, que tem como objetivo o fortalecimento da agricultura familiar, com geração de emprego e renda, sustentabilidade do homem do campo e promoção de segurança alimentar e nutricional. Com isso, o PAA deveria promover a articulação da agricultura familiar com programas sociais, operacionalizando a compra diversificada de produtos das famílias agricultoras e garantindo a doação às entidades participantes de programas sociais, como escolas ${ }^{46}$ e entidades filantrópicas (MDS, 2004).

A participação de agricultores do município de Lagoa Seca no PAA começou em 2006, através do mecanismo de compra direta com doação simultânea, uma das modalidades do programa. No primeiro ano, eram 10 agricultores familiares agroecológicos, mobilizados pelo Polo Sindical da Borborema. Em 2010/2011, o PAA aprovou, no

46 O envio de alimentos adquiridos via PAA a escolas públicas não compromete os recursos disponibilizados para merenda escolar. Com estes recursos, do Programa Nacional de Alimentação Escolar (PNAE), decidiu-se, em 2009, em lei n. 11.947 de 16 de junho, destinar 30\% do montante de recursos repassado pelo FNDE para serem utilizados na compra de produtos da agricultura familiar e/ou do empreendedor familiar rural, mecanismo que vem sendo utilizado em Lagoa Seca a partir de 2011. 
município, quatro projetos, beneficiando 35 agricultores familiares, de 08 comunidades rurais, organizados em quatro associações de produtores. Os projetos foram elaborados pela Secretaria de Agricultura de Lagoa Seca e submetidos a CONAB/PB. Foram investidos no programa, neste ano, $\mathrm{R} \$ 145.304,80$.

Mais do que avaliar se o PAA fortaleceu ou não a agricultura familiar em Lagoa Seca, lócus de realização da pesquisa de campo, buscou-se analisar como a vinculação ou não ao programa expressa diferenças entre agricultores familiares, ao mesmo tempo em que ajuda a estabelecer novas diferenças entre eles. Considerando que é uma categoria marcada por uma grande diversidade de atores sociais e pela ação incisiva de mediadores públicos e de representantes da sociedade civil.

Neste artigo, problematizou-se, assim, a partir da reflexão das possíveis contribuições e impactos que o PAA, em seus nove anos de atuação, possa ter provocado nas propriedades familiares e na vida econômica dos agricultores envolvidos com a comercialização de produtos via mercado institucional. É importante apreender, neste sentido, as maneiras pelas quais os possíveis benefícios são efetivados, estimulando o debate acerca das potencialidades e limites do programa.

O município de Lagoa Seca está situado na Mesorregião do Agreste Paraibano e Microrregião de Campina Grande, com uma população de $25.900^{47}$ habitantes, sendo 15.330 habitantes residentes na zona rural, o que representa 59,19\% da população total. São 33 comunidades rurais, o que corresponde a mais de 70\% de toda a área territorial do município. Constitui um município onde as atividades agrícolas têm uma forte importância econômica, pois, depois do setor de serviços, é o setor agropecuário que responde pela maior participação na composição do produto interno bruto do município (IBGE, 2010). Vale ressaltar que é uma agricultura bastante diversificada.

Em Lagoa Seca, num universo de 1.592 estabelecimentos familiares (IBGE, 2006), o programa beneficiou, em 2010/2011,

47 Censo demográfico 2010 - Instituto Brasileiro de Geografia e Estatística - IBGE 
diretamente 35 famílias, representadas por quatro associações. Diante da constatação desta pequena participação no programa, em que os beneficiários fornecedores representam 2,2\% dos estabelecimentos familiares do município, emergem mais questionamentos acerca da efetividade do PAA.

Para alcançar os objetivos propostos, na pesquisa considerei tanto dados secundários quanto aqueles produzidos em trabalho de campo realizado no meio rural de Lagoa Seca, além de análise dos documentos que permitiram a apreensão da institucionalização do PAA. Os principais dados secundários referem-se a informações disponibilizadas sobre o Programa de Aquisição de Alimentos e o município de Lagoa Seca, assim como históricos da execução do programa no município e em outros níveis.

\section{Contornos Institucionais do PAA}

O Programa de Aquisição de Alimentos foi criado em 2003, como parte das políticas implementadas pelo governo brasileiro com a finalidade de incentivar a agricultura familiar (Lei no 10.696, de 02 de julho de 2003). Para a execução do PAA, os Ministérios do Desenvolvimento Social e Combate à Fome e do Desenvolvimento Agrário - apoiados operacionalmente pela CONAB - firmam parcerias com governos estaduais, municipais, organizações da sociedade civil e da agricultura familiar e entidades filantrópicas.

De acordo com Grisa (2009), o PAA resultou da confluência entre dois debates importantes da década de 1990 no Brasil. Em primeiro lugar, o Programa traz a discussão da segurança alimentar e nutricional, intensificada a partir do final da década de 1980, tendo experimentado retração nos anos 1990 até que encontrou maior espaço no governo Lula, a partir de 2003. Em segundo lugar, o programa se insere no processo de reconhecimento da agricultura familiar, que ganhou maior expressão com a criação do PRONAF em 1996, mas, até então, permanecia à margem das ações do Estado, sofrendo os efeitos do processo de mudança da matriz tecnológica da agricultura das décadas de 1960 e 1970 (Revolução Verde) e, de modo mais alongado, as consequências da estrutura 
agrária desigual que caracterizou a formação econômica e social do Brasil.

O Programa de Aquisição de Alimentos é um exemplo de desdobramento de política pública que se enquadra no modelo de arenas sociais, já que a formulação da mesma se deu a partir de lutas sociais vinculadas a questões problemas, seja no campo da segurança alimentar e nutricional, como das desigualdades sociais no campo brasileiro. Nesse sentido, para que uma determinada circunstância ou evento se transforme em um problema, é preciso que as pessoas se convençam de que algo precisa ser feito. É por este motivo que a sociedade civil tem um papel fundamental na formulação desse tipo de política.

Nesse enfoque, a formulação das políticas públicas é intencional, parte de algum problema diagnosticado, e tem como interesse beneficiar determinados grupos sociais. O PAA faz parte dos programas diferenciados de desenvolvimento rural e se enquadra em uma política pública de caráter setorial, mas não isolada, já que reúne uma vasta rede de atores e beneficiários que estão distribuídos em áreas de interesses distintas.

Desde a sua criação, o PAA foi pensado a partir do Ministério do Desenvolvimento Social e Combate a Fome, sendo uma das ações do Programa Fome Zero. No entanto, logo se percebe sua intersetorialidade, dada sua inserção no Ministério do Desenvolvimento Agrário, assim como sua transversalidade, já que muitos dos produtos adquiridos são doados para incrementar a merenda escolar, favorecendo o Programa Nacional de Alimentação Escolar, atingindo diretamente o Ministério da Educação e as Políticas de Segurança Alimentar. Além do mais, prioriza temas que estão presentes em vários setores como desenvolvimento social, desenvolvimento rural, combate à fome, segurança alimentar, dentre outros, mostrando assim a interseccionalidade desta política. Uma análise das leis e decretos que regulam o programa desvenda como as categorias sociais beneficiadas pelo PAA se cruzam e se modificam no desenrolar da política, produzindo integração e desenvolvimento social. Nesse âmbito, o programa pode ser analisado a partir dos estudos de interseccionalidade de Olena Hankivsky (2010). 
Pelo seu caráter democrático, o PAA pode ser analisado através do modelo do ciclo da política pública, já que esta tipologia aborda a política pública como um ciclo deliberativo, formado por vários estágios e constituindo um processo dinâmico e de aprendizado. Contudo, a escassez de estudos "pós-decisão" faz com que a análise das políticas públicas continue gravitando na órbita das questões analíticas mais tradicionalmente valorizadas pela ciência política, resultado da frágil institucionalização e debilidade desse campo de estudos no Brasil (FARIA, 2003).

Entre 2003 e 2005, os recursos destinados ao programa eram repassados à CONAB pelo MDS, por meio de convênios. Em 2006, o MDA firmou um Termo de Cooperação Técnica com a CONAB, disponibilizando recursos para aquisições com formação de estoque. Tais investimentos têm sido incrementados desde sua implantação, levando em consideração o crescimento do números de projetos aprovados, embora ainda atenda um número pequeno de agricultores. Os recursos evoluíram de $\mathrm{R} \$$ 81.541.207,00 em 2003 para $\mathrm{R} \$ 451.036 .204,00$ em 2011, um acréscimo da ordem de 453,13\% (CONAB, 2004; 2005; 2006; 2007; 2008; 2009; 2010; 2011; 2012).

No Estado da Paraíba, o programa esteve em execução a partir de 2004, com investimentos iniciais de $\mathrm{R} \$ 1.710 .783,04$ em aquisição de produtos da agricultura familiar com recursos do MDS. 0 programa obteve alguns sobressaltos no estado, já que, em alguns anos, o montante de recursos decresceu, como foram os casos dos anos de $2006(\mathrm{R} \$ 325.200,00), 2007(\mathrm{R} \$ 1.337 .240,00)$ e 2009 ( $\mathrm{R} \$$ $625.717,00)$.

\section{O PAA em Lagoa Seca}

Entre 2005 e 2006, iniciou-se a "Compra Antecipada Especial da Agricultura Familiar com Doação Simultânea", modalidade do Programa de Aquisição de Alimentos (PAA) no município de Lagoa Seca. O projeto inicial teve o Polo Sindical da Borborema como entidade proponente em parceria com o MDA, através da CONAB, as Prefeituras Municipais e os Sindicatos dos Trabalhadores Rurais dos municípios de Lagoa Seca, Soledade e Queimadas. Nos três 
municípios, a compra de produtos da agricultura familiar contribuiu com a alimentação de 970 crianças de escolas e creches em 13 estabelecimentos de ensino - 08 escolas e 05 creches - com 56 produtos hortifrutigranjeiros agroecológicos regionais, num valor total de $\mathrm{R} \$ 64.675,00$ produzidos por 32 agricultores familiares. Em Lagoa Seca, participaram 10 agricultores das Associações dos Agricultores de Jucá e Amaragi. Dentre as entidades receptoras, constavam três escolas e duas creches.

O programa teve continuidade no município entre 2008/2009, complementando a alimentação de dez escolas e duas creches, totalizando 1024 crianças, um asilo com 15 idosos e um banco de alimentos que atendeu 1500 pessoas, beneficiadas através da oferta de produtos agrícolas, como hortaliças, frutas, galinha, ovos, bolos, doces etc., encaminhados por 21 agricultores e agricultoras, participantes das associações de agricultores rurais das localidades de Pai Domingos, Retiro e Manguape, Jucá e Boa Vista, e Cumbe e

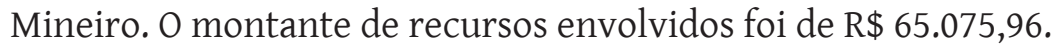

Já entre 2009 e 2010, em Lagoa Seca, participaram do programa 35 agricultores e agricultoras das mesmas associações citadas, beneficiando 15 escolas municipais, duas creches, uma escola estadual, um banco de alimentos, um asilo e um hospital, totalizando 6.501 beneficiários consumidores e um montante de $\mathrm{R} \$ 145.304,80$ de recursos envolvidos. Estes projetos estenderam-se até junho de 2011.

No segundo semestre de 2011, foram elaborados os projetos para 2011/2012. No entanto, no primeiro semestre de 2012, os projetos ainda não haviam sido iniciados por falta de recursos. 0 projeto envolveu mais uma vez 35 agricultores das associações de agricultores do Retiro e Manguape, Jucá e Boa Vista, e do Cumbe e Mineiro totalizando um montante de $\mathrm{R} \$ 157.323,23$ de recursos previstos. Produtos que seriam doados a 26 escolas e um banco de alimentos comunitários.

A Associação dos Pequenos Produtores dos Sítios Retiro e Manguape I, situada na Região dos Roçados, iniciou sua participação no PAA no ano de 2008/2009 e logo no segundo ano, 2009/2010, evoluiu consideravelmente no número de agricultores atendidos, passando de cinco para 15 beneficiários; em termos de recursos aplicados, 
passou-se de $\mathrm{R} \$ 14.605,00$ para $\mathrm{R} \$ 66.362,00$; e na média de benefícios por agricultor/ano, de $\mathrm{R} \$ 2.921,00$ para $\mathrm{R} \$ 4.424,00$. Para o projeto $2011 / 2012$, estava previsto atender 17 agricultores com uma média de $\mathrm{R} \$ 4.495,64$ agricultor/ano. Com o decorrer do programa, podese evidenciar que as médias de recursos por agricultor/ano estão se aproximando do valor da cota máxima de $\mathrm{R} \$ 4.500,00$.

Os produtos fornecidos nas duas etapas de execução foram: batata doce, galinha caipira, bolo de macaxeira, bolo de mandioca, bolo de milho, pé-de-moleque, doce de mamão e doce de goiaba. Nesse último projeto, ocorreu uma diminuição na diversidade dos produtos comercializados, motivada pela exclusão dos produtos processados. Os únicos produtos fornecidos por essa associação foram batata doce e galinha caipira.

Segundo Valdeci Ferreira, encarregado da CONAB, para os produtos processados, a questão é com a vigilância sanitária local ou estadual, pois é exigida dos agricultores uma estrutura mínima, como uma cozinha comunitária apropriada para o processamento dos alimentos. Como cada fornecedor preparava os produtos em suas cozinhas, não foi aceito pela vigilância sanitária. É necessário embalar os produtos, colocar um selo contendo os ingredientes, a data de fabricação, a validade, etc. Essas são as exigências mínimas.

A Associação dos Agricultores Familiares do Sítio Pai Domingos, com sede na Região das Verduras, iniciou no PAA em 2008/2009 com R\$7.915,96 de recursos aplicados e em 2009/2010 recebeu R\$ 20.915,96 de investimentos. O número dos beneficiários aumentou de três para cinco agricultores; enquanto a média de recursos por agricultor aumentou de $\mathrm{R} \$ 2.638,65$ para $\mathrm{R} \$ 4.115,60$. A evolução do PAA para essa associação foi bem mais modesta que a apresentada pela associação do Retiro e Manguape I.

Os produtos fornecidos foram: abóbora de leite, abobrinha, acelga, alface, batata doce, berinjela, brócolis, cebolinha, cenoura, chuchu, coentro, couve, espinafre, feijão verde, macaxeira, pimentão, repolho, vagem, couve-flor, beterraba, bolo de macaxeira, bolo de mandioca, pé-de-moleque, cocada e doce de goiaba. Para os anos 2011/2012, não foi elaborado projeto para essa associação. 
Os agricultores alegaram que os principais produtos oferecidos por eles eram os processados, excluídos do programa.

Além do mais, dois dos agricultores que forneceram hortaliças, nos projetos anteriores, migraram para o projeto coordenado pelo Polo Sindical da Borborema. Os agricultores decidiram participar dos projetos da ECOBORBOREMA, entidade vinculada ao Polo Sindical da Borborema, que com seu trabalho de assessoria diminuiu a burocracia do programa e facilitou o processo de pagamento dos produtos fornecidos.

Instaura-se, assim, uma diferenciação entre os agricultores participantes dos projetos assessorados pela Secretaria de Agricultura de Lagoa Seca e os coordenados pelo Polo, sinalizando, como já revelou Costa (2010), para a existência de inter-relações entre os atores e mediadores, que não se expressam somente em relações de solidariedade e/ou reciprocidade, mas também de disputa de poder, conflitos de interesses e mecanismos de coerção, comprometendo a coerência de execução do programa.

A Associação de Desenvolvimento Econômico, Social e Comunitário dos Sítios Cumbe, Mineiro e adjacências, que reúne agricultores da região das Frutas, iniciou no PAA em 2008/2009, acessando recursos da ordem de $\mathrm{R} \$ 5.357,30$, e no projeto de 2009/2010, esse valor passou para 19.416,80; beneficiando, de inicio, três agricultores com uma média de benefício de $\mathrm{R} \$ 1.785,76$ por agricultor/ano e, posteriormente, cinco agricultores, com benefício médio de $\mathrm{R} \$ 3.883,36$ por agricultor/ano. Já no projeto 2011/2012, que estava aguardando recursos no momento de realização da pesquisa, cinco agricultores continuarão sendo beneficiados, dessa vez com um valor de $\mathrm{R} \$ 4.495,46$ por agricultor/ano, somando um montante de $\mathrm{R} \$ 22.477,33$.

É perceptível que não tem havido aumento expressivo no número de agricultores vinculados ao PAA, ainda que o valor médio por agricultor/ano esteja chegando próximo à cota máxima. Os produtos fornecidos foram: alface, cebolinha, coentro, espinafre, vagem, couve, chuchu, pimentão, goma de mandioca, laranja pera, limão, manga espada, tangerina, laranja cravo, banana pacovan e 
abacate. Para o projeto encaminhado em 2011/2012, a diversidade de produtos também diminuiu.

A Associação de Desenvolvimento Econômico e Social das comunidades Jucá e Boa Vista, situada na Região das Frutas, foi a única que teve agricultores participantes no primeiro projeto PAA em Lagoa Seca, nos anos de 2005/2006. Em 2008/2009, esta entidade recebeu investimentos de R $\$ 28.576,50$, já em 2009/2010 foram R\$38.938,00, e para o projeto $2011 / 2012$, o investimento previsto era de $\mathrm{R} \$ 58.419,90$, beneficiando entre 2008 e $2010 \mathrm{dez}$ agricultores e para 2011/2012, 13 agricultores. A média de benefício por agricultor/ano elevou-se, respectivamente, de $\mathrm{R} \$ 2.857,65$ para $\mathrm{R} \$ 3.893,00$ e, finalmente, para $\mathrm{R} \$ 4.493,83$. Os produtos fornecidos foram: abacate, banana pacovan, laranja pera, laranja cravo, tangerina, batata doce, chuchu, doce de banana, doce de mamão, macaxeira, ovos de galinha.

É preciso se questionar sobre os motivos que levaram à redução da diversidade de produtos vendidos no mercado institucional ou à especialização do fornecimento.

\section{Agricultura Familiar em Lagoa Seca: características e diferenciações}

A amostra da agricultura familiar considerada nesta pesquisa não revela, necessariamente, as características do setor no município de Lagoa Seca. Devido aos interesses da investigação que dá suporte a este artigo, a amostra da pesquisa privilegiou agricultores familiares vinculados ao PAA e agricultores não vinculados com propriedades em áreas próximas aos primeiros. Foram pesquisadas 40 famílias de agricultores familiares, das quais, 26 vinculadas ao PAA, que estão ativas em suas funções agrícolas. Esse universo de pesquisa compreende 178 pessoas, sendo $49,44 \%$ do sexo masculino e $50,56 \%$ do sexo feminino. Os dados levantados, porém, oferecem bons indicadores para se conhecer de modo mais aprofundado algumas das características dos agricultores familiares de Lagoa Seca e as diferenciações existentes entre eles. Uma diferença a ser mencionada é que a pesquisa sinalizou, para os agricultores da amostra, uma taxa de escolarização mais alta para os agricultores 
não vinculados ao PAA, o que parece ser um dado relevante, ainda que não se possa, no momento, avançar muito sobre as explicações para essa diferença.

Em meio aos agricultores entrevistados, 65\% já tiveram alguma experiência de participação no Programa de Aquisição de Alimentos - PAA. Dentre esses, 46,15\% participam somente há 02 anos do programa, 23,08\% estão há 3 anos, os que participam há $4 \mathrm{e}$ 6 anos obtiveram o mesmo percentual de $11,54 \%$ e somente $7,69 \%$ participam há 5 anos do programa. Os dados demonstram que a experiência do programa para maior parte dos agricultores é algo recente, podendo resultar do processo de mediação de conflitos ou lutas contra a derrubada dos entraves para o ingresso no PAA.

Trabalho e renda - Os dados relativos à ocupação da mão-de-obra revelam que $64,71 \%$ dos membros das famílias pesquisadas (em idade laboral) dedicam-se integralmente a atividades agropecuárias na propriedade familiar. Outros 20,17\% combinam o trabalho na propriedade com estudo ou trabalho fora da propriedade. Chega-se, assim, a $84,88 \%$ da força de trabalho dedicada a atividades na propriedade familiar. Entre as famílias não vinculadas ao PAA, porém, a ocupação da mão-de-obra familiar na propriedade da família chega a 85,72\% (tempo parcial, 16,67\% e tempo integral, 69,05\%), ligeiramente superior ao valor encontrado para as famílias vinculadas ao PAA, que foi de $84,42 \%$ (tempo parcial, 22,08\% e tempo integral 62,34\%). Estes dados não diferem muito daqueles registrados pelo Censo Agropecuário de 2006, que indicou que $80,52 \%$ dos agricultores familiares não desenvolviam atividade econômica fora do estabelecimento, o que representa o seu comprometimento nas atividades agrícolas.

Dos membros das famílias pesquisadas em idade produtiva, $15,13 \%$ estão ocupados fora da unidade familiar. Essas atividades realizadas fora da unidade familiar estão dispersas em vários setores, como nos serviços públicos, construção civil, transportes, comércios, moto táxi, etc. São principalmente os filhos que buscam novas oportunidades de trabalho.

A média de mão-de-obra utilizada nas unidades produtivas visitadas foi de 2,85 da força de trabalho familiar e 1,38 da força de trabalho contratada. Cerca de $70 \%$ das famílias pesquisadas 
contratam trabalho não familiar. Dentre elas, $64,29 \%$ contratam mão-de-obra de forma sazonal nos meses de cultivo da terra ou nas épocas de colheita. Somente 35,71\% contratam de forma permanente. A predominância da contratação da mão-de-obra sazonal não se justifica pela ausência de trabalho nas unidades, mas pela falta de condições financeiras para contratação permanente. Muitos dos agricultores citaram que um dos problemas da atividade agrícola é a falta de mão-de-obra, por ter aumentado o número dos familiares que não podem exercer atividades na propriedade, por estarem estudando ou empregados em atividades não agrícolas.

Nas unidades familiares participantes do PAA, identificou-se um maior percentual de mão-de-obra contratada de forma sazonal. Em contrapartida, as unidades não participantes do PAA tem o maior percentual de mão-de-obra contratada de forma permanente. Segundo os agricultores participantes, como o PAA não é perene, entre o encerramento de um projeto e o início de outro, existe uma pausa no repasse dos produtos acompanhado da incerteza do retorno, dificultando a manutenção de mão-de-obra contratada.

Esse é um motivo para identificar a inserção no mercado (mesmo que via atravessadores) e possível capitalização dos agricultores não participantes do PAA, cuja capacidade de contratação parece ser consequência da garantia de comercialização ${ }^{48}$. Coloca-se, assim, uma importante questão acerca da adesão a mercados institucionais como estratégia específica de certos agricultores e a orientação para os mercados considerados tradicionais, por parte de outros agricultores de Lagoa Seca, sem que seja possível com base na pesquisa realizada demonstrar as bases que fundamentam estas diferentes estratégias.

Quando questionados no que diz respeito à principal fonte de renda da família, 70\% dos entrevistados informaram que a maior parte da renda familiar vem das atividades agrícolas realizadas dentro da unidade produtiva. Outra fonte de renda com impacto expressivo na caracterização da renda familiar das propriedades

48 Posteriormente veremos que os agricultores não familiares têm como principal forma de comercialização a Empasa (centro de distribuição) e os atravessadores. 
pesquisadas foi a aposentadoria ou pensão, que representam a maior parte da renda para $20 \%$ das famílias. Somente $10 \%$ das famílias informaram que a renda mais expressiva da família vinha de atividades não agrícolas (desconsiderando-se os benefícios previdenciários).

Dentre as famílias entrevistadas, 42,5\% recebem bolsa família, $35 \%$ são beneficiados com aposentadoria, 2,5\% recebem concomitantemente bolsa família e aposentadoria e $20 \%$ das famílias não recebem nenhum tipo de repasse da previdência ou de programas de transferência de renda. Dentre os que recebem bolsa família, o percentual é maior entre os que participam do PAA. Estes chegam a 50\% das famílias, contra $35,71 \%$ dos que não participam do programa, dados que são coerentes com uma maior capitalização e inserção no mercado dos agricultores que não participam do PAA confirmados na pesquisa de campo.

Características das propriedades - No que se refere à caracterização das propriedades, $95 \%$ delas são próprias, ressaltando que $32,5 \%$ são terras de herdeiros que ainda não foram legalizadas, enquanto 5\% dos agricultores entrevistados são meeiros. Não foi identificada qualquer propriedade arrendada. Os meeiros identificados compõem 7,69\% dos agricultores que participam do PAA, enquanto os agricultores que não fazem parte do PAA se caracterizam pelo percentual de $100 \%$ de propriedades próprias.

O tamanho médio das propriedades pesquisadas é de 3,67 hectares, número bem aproximado dos dados do Censo Agropecuário 2006, que apontou o tamanho médio das unidades familiares em Lagoa Seca de 2,96 hectares. No entanto, entre os agricultores familiares, existem disparidades no que concerne ao tamanho das propriedades, pois a maior propriedade pesquisada era de 15 hectares e a menor, 0,25 hectares.

Formas de comercialização - As unidades produtivas estudadas têm várias formas de destinação para o que é produzido. A vinculação a mercados institucionais (Governo, Estado, prefeituras, etc.) não é exclusiva dos agricultores vinculados ao PAA. Nesse item, estamos considerando a participação dos agricultores não só no PAA, mas também no Programa Nacional de Alimentação Escolar 
(PNAE), que instituiu como lei ${ }^{49}$ a compra de no mínimo 30\% dos produtos da alimentação escolar na agricultura familiar local. Dos agricultores não vinculados ao PAA, 14,29\% já abastecem a alimentação escolar através do PNAE. Entre os entrevistados, 19,33\% dos participantes do PAA interromperam o fornecimento para o programa por entraves ${ }^{50}$ ocasionados pelas associações de agricultores ou exigências ocasionadas pela CONAB e a vigilância sanitária.

Outra forma de comercialização bastante praticada é a comercialização na propriedade (40\%), caracterizada pela presença dos atravessadores na mediação entre os produtores e o mercado consumidor. Entre os agricultores não participantes do PAA, esse percentual foi de 57,14\%. E para os que participam do programa, esse percentual foi de 30,77\%. Com isso, pode-se considerar que as comercializações no mercado institucional e nas feiras se revelam como responsáveis pelo distanciamento dos atravessadores na mediação da produção.

Dentre os entrevistados, 37,5\% comercializam sua produção em feiras livres, sendo os agricultores considerados agroecológicos os que prevalecem, por terem um mercado "em expansão" (mercado de produtos orgânicos ou agroecológicos), assim como feiras especializadas na distribuição desse tipo de produção. Essa participação é fruto da mobilização política e de engajamentos destes agricultores com o apoio do Sindicato, EMATER e AS-PTA. O maior percentual de participação nas feiras é dos produtores ligados ao PAA (50\%), enquanto entre os que não participam o percentual de engajamento nas feiras é de $14,29 \%$. Os dados sinalizam que a articulação entre os agricultores, fruto da mobilização política, deu origem a novos espaços para comercialização dos produtos: os mercados institucionais e as feiras.

Entraves na produção - Dentre as dificuldades percebidas pelos agricultores no que concerne à produção no interior das unidades, a mais citada, por 32,5\% dos entrevistados, refere-se à falta

49 Lei no 11.947 , de 16 de junho de 2009.

50 O tema que será abordado posteriormente. 
de mão-de-obra, ressaltando que, entre os agricultores não participantes do PAA, esse percentual sobe para $50 \%$.

O segundo maior problema citado foi a falta de assistência técnica, considerada como problema por $27,5 \%$ dos agricultores. Entre os não vinculados ao PAA, esse percentual sobe para $42,86 \%$. $O$ custo de produção elevado e os baixos preços de comercialização foram considerados como dificuldades para $25 \%$ deles, já $22,5 \%$ consideraram a falta de crédito, as pragas e a falta de mercado como entrave para produção. Ao falar dos limites para comercialização, os entrevistados se referiram à falta de mercado, mas pode-se interpretar esta dificuldade nas relações conflituosas com o mercado, ou seja, nas dificuldades de inserir-se em espaços mais capitalizados.

Outras dificuldades citadas pelos produtores foram a falta de água $(12,5 \%)$, a dificuldade no transporte da produção (10\%) e os atravessadores (7,5\%). Cabe destacar que a insatisfação com os atravessadores foi citada somente entre os agricultores não participantes do PAA, podendo identificar um ponto positivo do programa, pois o excedente da produção que talvez fosse comercializado com os atravessadores está sendo fornecido para o PAA. Foram citados ainda problemas com a conservação do solo e adubação, falta de irrigação, problemas com os donos da propriedade (no caso dos meeiros), baixa lucratividade, falta de mecanização, dívidas com financiamento, demora no acesso ao crédito, problemas climáticos, etc.

Se vários fatores naturais ou antrópicos são detectados como entraves para a produção agrícola, quando o público alvo é a agricultura familiar, as dificuldades se multiplicam, principalmente quando a solução para muitos desses problemas dependerem de ações públicas. Durante as entrevistas, era perceptível a indignação dos agricultores pesquisados quando os mesmos se referem aos órgãos governamentais, pela morosidade ou pela ineficiência muitos desistem de recorrer a esses auxílios o que exige uma melhor estruturação para a assistência técnica dessas famílias.

A caracterização das unidades sinaliza para maior capitalização e melhor relação com o mercado dos agricultores que não participam do PAA. Os mesmos se sobressaem em vários aspectos, tais como: capacidade de contratação de mão-de-obra permanente, 
menor percentual de participação na bolsa família, maior percentual de propriedades próprias, etc. Além do mais, apesar de alguns deles já estarem articulados com o mercado institucional mediante o Programa Nacional de Alimentação Escolar - PNAE, a maioria não demonstra interesse em participar do PAA. Entre esses, 64,29\% deles negaram ter conhecimento do PAA e $28,57 \%$ enfatizaram não ter vontade de participar, principalmente, por não acreditar nessa política. Já os agricultores que acessam o PAA são os que estão ligados direta ou indiretamente às associações de agricultores, engajados com o sindicato, EMATER, Secretaria de agricultura, AS-PTA, etc.

Os participantes do PAA não citam os atravessadores como problema. No entanto, mesmo participando em sua grande maioria das feiras, apontaram como problema a falta de mercado. Além disso, os agricultores não vinculados ao PAA que citam os atravessadores como entraves demonstram preferir vender para eles a ter que se submeter ao mercado institucional, por julgarem burocráticos e morosos. Com isso, o PAA pode até sinalizar para um distanciamento dos atravessadores na mediação da produção, favorecendo uma garantia de escoamento e de remuneração "mais justa", no entanto o processo burocrático e descontínuo ainda dificulta a inserção de um número maior de agricultores.

\section{O PAA e suas transformações para os agricultores familiares}

Quando questionados sobre a representação da renda adquirida no PAA para a sua renda mensal, 69,23\% afirmaram que seria um valor complementar, enquanto que $23,08 \%$ afirmaram ser parte significativa do orçamento familiar. Já 7,69\% consideram que os ingressos do PAA formam a maior parte da renda, o que pode representar uma questão a ser investigada já que o projeto estipula uma cota por agricultor de $\mathrm{R} \$ 4.500,00$ por ano.

$O$ projeto do PAA tem duração de até 10 meses, fazendo com que a renda mensal no período seja de $R \$ 450,00$ para aqueles que conseguiram alcançar o limite da cota. Quando se subtraem os investimentos na produção, as despesas com insumos e mão-de-obra, transporte das mercadorias e impostos pagos, o lucro final fica 
comprometido. Uma família que tem no programa a maior fonte da renda demonstra uma dependência do mercado institucional e a falta de alternativas para escoamento da produção, podendo também justificar o alto índice de famílias que recebem o bolsa família como alternativa de sobrevivência.

Como evidencia Delgado (2001), por melhores que sejam as políticas, sua execução enfrentará sempre terríveis dificuldades, principalmente no Brasil, onde a população é predominantemente urbana, a agricultura é complexa e articulada aos interesses agroindústrias. O dinamismo econômico e a criação de novos empregos estão atrelados a condições políticas que influenciem decisivamente os rumos da política econômica e social do País. Os agricultores familiares são os principais excluídos dessas políticas, de modo que sua luta é, acima de tudo, pela conquista da condição de cidadãos, com mínimos direitos políticos, econômicos e sociais.

Um dos maiores questionamentos dos agricultores vinculados ao PAA é quanto ao valor da cota de $\mathrm{R} \$ 4.500,00$ por agricultor/ano - 88,46\% afirmaram ter condições de produzir mais que esse valor. Dos agricultores vinculados ao PAA, 73,07\% não estão satisfeitos com o valor das contas, já 26,92\% dizem estar satisfeitos, mesmo apresentando capacidade de produzir mais.

No entanto, o grupo gestor prefere manter a cota e atender um número maior de agricultores, a aumentar a cota, o que demanda uma quantidade maior de recursos para atender o mesmo número ou mais de agricultores. Além de justificar o baixo valor com a possível participação em outros tipos de comercialização institucional, fazendo emergir mais uma questão no debate sobre o PAA que diz respeito à ineficiência no desenvolvimento econômico, não sendo capaz de, por si só, gerar a renda necessária para o sustento e melhoria dos agricultores familiares, que para isso, precisariam da inserção em outros programas e políticas.

No que se refere aos preços pagos pela Conab, $42,31 \%$ dos entrevistados consideram satisfatórios e 3,85\% estão muito satisfeitos, resultando em uma aceitação de 46,16\%. Já 19,23\% afirmaram estar insatisfeitos e $34,62 \%$ poucos satisfeitos, somando $53,85 \%$ de descontentamento. 
Em contrapartida, segundo o encarregado da CONAB, os agricultores não têm de que reclamar, pois a tabela de preços é definida depois de rigorosa pesquisa de preços, que ficam congelados durante todo o ano, mesmo nos momentos da safra onde os preços de determinados produtos despencam, no programa continuam os mesmos, proporcionando uma garantia de preço justo para o agricultor.

Quando questionados sobre as transformações verificadas na produção através da participação no PAA, 19,23\% afirmaram que não ocasionou nenhuma mudança, já $80,77 \%$ afirmaram obter algum tipo de modificação na produção com a venda dos seus produtos ao programa. Em 34,62\% das unidades produtivas, houve aumento na contratação de mão-de-obra, mesmo que não seja permanente, 23,08\% compraram algum tipo de maquinário, 19,23\% investiram na utilização de novas técnicas agrícolas, 15,38\% aumentaram a propriedade, 7,69\% adquiriram transporte para a produção e 53,85\% consideraram também outras mudanças na propriedade, como: aquisição de estrume, sistema de irrigação, cercou a propriedade, instrumentos de trabalho, aumento da produtividade, investimento na produção de peixe e na construção de barragem, etc.

É perceptível a existência de várias insuficiências nas unidades familiares estudadas, pois apresentam necessidades básicas para a realização do trabalho como esterco, mão-de-obra e insumos, etc. O PAA não resolve todas essas carências, mas, segundo os agricultores, ele resulta em um auxílio satisfatório.

Os agricultores que não participam do PAA também elencaram transformações em sua propriedade referentes à produção desde o ano de 2006. A mais relevante foi a utilização de novas técnicas agrícolas (35,71\%), seguida da contratação de mão-de-obra e compra de maquinário (21,43\%). É importante perceber que, nesse item, os participantes do PAA citaram como maior impacto a contratação de mão-de-obra, diferente dos não vinculados ao PAA, que identificaram as novas técnicas agrícolas, aspecto que justifica o problema da menor capitalização e capacidade de contratação dos participantes do PAA. Dentre os que não identificaram nenhuma 
transformação em suas propriedades, os percentuais foram praticamente iguais, 21,43\% para os não vinculados ao PAA e 19,23\% para os que aderiram ao programa.

Entre os agricultores que não participam do PAA, o percentual dos que afirmaram ter obtido melhorias na qualidade de vida da família desde o ano de 2006 foi de 71,43\%, um pouco menor que os participantes do programa, já que $88,46 \%$ desses afirmaram identificar algum tipo de contribuição oriunda dos recursos do PAA.

$O$ aumento da renda foi um dos aspectos mais evidenciados nas entrevistas. Foram citadas algumas aquisições fruto dos recursos do programa, como: compra de motocicleta, geladeira, batedeira de bolo, garrote, televisor, aparelho de som, móveis, contribuiu na reforma da casa, melhorou a renda, o conforto e alimentação.

Podem-se evidenciar aspectos pontuais no que diz respeito à representação dos recursos do PAA, demonstrando sua importância econômica para os agricultores vinculados. Nesse caso, o programa se legitima no campo da agricultura familiar, seja pelo nível de carência dos agricultores ou pela falta de alternativas de comercialização. Dos agricultores que já participam do programa, $80,77 \%$ afirmaram que pretendiam continuar participando.

\section{Potencialidades, Limites e Perspectivas do PAA}

A pesquisa revelou algumas deficiências no processo de execução do PAA. A principal delas refere-se às condições colocadas para inserção dos agricultores. A "burocracia” parece ser responsável pelo afastamento de muitos agricultores. Muitos entrevistados reclamaram da exclusão dos produtos processados, mesmo depois de algumas famílias terem feito adaptações em cozinhas para continuarem fornecendo bolos e doces, o que não impediu o veto a estes produtos e a sensação de desperdício dos investimentos feitos.

Alguns agricultores decidiram sair do programa por discordarem das decisões que eram tomadas nas associações de agricultores. As questões estão relacionadas à escolha dos agricultores participantes do PAA, na escolha dos produtos e problemas com o pagamento das mercadorias fornecidas. Na opinião deles, 
muitas das deliberações favoreceriam a uma minoria dos associados, fragilizando a participação dos demais agricultores.

É importante ressaltar que muitas das famílias incluídas na amostra da pesquisa buscaram inserção menos "burocrática" ao mercado institucional. Verificou-se que $38,46 \%$ dos agricultores que participam do PAA já estão inseridos em outras políticas com a mesma finalidade. Uma delas é a compra de $30 \%$ dos produtos da agricultura familiar e do empreendedor rural para a merenda escolar (Lei 11.947 de 16 de junho de 2009) com recursos repassados pelo FNDE.

Outro projeto que conquistou os agricultores foi Produção Agroecológica Integrada Sustentável (PAIS), parceria entre SEBRAE, Fundação Banco do Brasil e Ministério da Integração Nacional, por meio da Secretaria de Programas Regionais. O PAIS inspirou-se na atuação de agricultores familiares que optaram por fazer uma agricultura sustentável, sem uso de agrotóxicos e com a preocupação de preservar o meio ambiente, agregando técnicas simples e já conhecidas em muitas comunidades rurais.

Dos agricultores que não participam do PAA, 21,43\% estão engajados no fornecimento de produtos para o PNAE ou participam do programa PAIS. Todavia, a maioria dos entrevistados acredita que o PAA tem mais vantagens, que é melhor, indicando, com isso, a sua legitimação, mesmo diante dos limites da política. Além da comercialização direta sem a necessidade do atravessador, a preferência pelo PAA por parte dos agricultores familiares está atrelada ao seu tempo de execução e por seu pioneirismo no estabelecimento do mercado institucional para a agricultura familiar no Brasil.

Os aspectos favoráveis ao PAA mais citados pelos agricultores foram a melhoria da renda na unidade familiar e a garantia da comercialização do que está sendo cultivado, fatores que resolvem parcialmente o problema da carência de renda e da falta de alternativa de comercialização. No entanto, os fatores abordados ainda não são capazes de revelar se o programa é capaz de gerar desenvolvimento de forma qualitativa e sustentável.

Em que pesem os pontos favoráveis, os desafios presentes na construção de um mercado institucional para os produtos da agricultura familiar não podem ser esquecidos. Foram também citados 
pontos negativos do PAA, como problemas com o pagamento. A demora entre a finalização de um projeto e o início do outro chama a atenção para o aspecto descontinuado do programa, não permitindo que os agricultores tenham progressos mais expressivos. Se uma vez cadastrados, os agricultores comercializassem permanentemente com o programa, os resultados poderiam ser mais expressivos tanto economicamente, quanto na vida das famílias.

Mesmo diante dos obstáculos, 73,08\% dos participantes avaliam positivamente as novas políticas públicas criadas pelo governo brasileiro a partir de 2003, que desburocratizam a comercialização com o mercado institucional. Já $26,92 \%$ avaliaram como regular, reconhecendo a importância do programa, mas ressaltando a existência de obstáculos.

Para Schimitt e Guimarães (2008, p.12), “o ingresso nos mercados institucionais, particularmente na compra com doação simultânea, promoveu o acesso dos produtores a um mercado próximo, capaz de absorver grande diversidade de produtos”. Mas é necessário ressaltar que há grande expectativa para que o PAA deixe de ser um programa, uma política de governo e se efetive como política de estado ${ }^{51}$ ampliando com isso o valor das cotas, o número de participantes e os recursos.

A promoção do programa para a categoria de política de estado pode ampliar bastante os horizontes de abrangência do PAA, assegurando a comercialização para agricultores fornecedores e garantindo a segurança alimentar e nutricional para os consumidores, principalmente, o público escolar. Isso também somado a mudanças mais específicas que precisam envolver a execução do programa, desde o espaço nacional ao espaço local, onde o

51 Considera-se que políticas de governo são aquelas que o Executivo decide num processo elementar de formulação e implementação de determinadas medidas e programas, visando responder às demandas da agenda política interna, ainda que envolvam escolhas complexas. Já as políticas de Estado são aquelas que envolvem mais de uma agência do Estado, passando em geral pelo Parlamento ou por instâncias diversas de discussão, resultando em mudanças de outras normas ou disposições preexistentes, com incidência em setores mais amplos da sociedade (OLIVEIRA, 2011, p.329). 
programa é executado, dando mais visibilidade à participação dos agricultores como atores ativos e protagonistas do desenvolvimento em âmbito local.

\section{Considerações Finais}

Para o fomento da agricultura familiar, as políticas públicas apresentam um papel fundamental, principalmente as que possibilitam a superação das desigualdades e o exercício da cidadania. No entanto, se por vários fatores naturais ou antrópicos são detectados entraves para a produção agrícola, quando o público alvo é a agricultura familiar, as dificuldades se multiplicam, principalmente quando a solução para muitos desses problemas dependem de ações públicas.

Nas unidades familiares pesquisadas, foram observados problemas estruturantes no contexto das atividades agrícolas, que não estão sendo suficientes para o sustento da família, sendo possível perceber a necessidade da busca de alternativas de trabalho fora da propriedade familiar como tática da família para garantir a reprodução e sua permanência no espaço rural, buscando novas oportunidades, mas, permanecendo no campo, evidenciando o valor simbólico e de pertencimento que o meio rural representa.

Diante das dificuldades de inserção em mercados mais capitalizados, a articulação entre os agricultores, fruto da mobilização política desta categoria, deu origem a novos espaços para comercialização dos seus produtos, como os mercados institucionais e as feiras.

As estratégicas públicas de comercialização com o mercado institucional, apesar de recentes e de apresentarem desafios e limites, têm se mostrado favoráveis ao processo de desenvolvimento da agricultura familiar. No entanto, os agricultores que acessam essas políticas públicas são os que estão ligados direta ou indiretamente às associações de agricultores, engajados como o sindicato, EMATER, Secretaria de agricultura, AS-PTA, etc. Os que não conseguem incluir-se não tem ao menos conhecimento dessas políticas, ficando à margem de todo esse processo ou então demonstram estar inseridos no mercado e não têm interesse em participar do PAA. 
Nesse sentido, um dos desafios para estas políticas públicas é dar conta da diversidade de situações sociais reunidas sob a rubrica da agricultura familiar. Diferenciações que não se expressam apenas entre agricultores de diferentes regiões do país, mas que estão bem presentes num mesmo município, como Lagoa Seca.

O PAA tem como finalidade beneficiar os agricultores familiares que estão enquadrados segundo a categorização do Pronaf. No entanto, ao considerar os participantes do programa, revela-se o surgimento de novas diferenças que distanciam as propriedades familiares: no poder decisório, em sua inserção nas etapas de execução do programa, nos diferentes impactos do programa para as famílias, etc., revelando as congruências e heterogeneidades desse grupo.

O relato da experiência, inicialmente, do Sr. Manoel Inácio, 49 anos, presidente da associação de agricultores dos Sítios Jucá e Boa Vista e, posteriormente, ampliado para os demais agricultores da amostra da pesquisa, sinaliza que, ao estarem vinculados ao PAA, os agricultores ampliam seus horizontes para novas formas de comercialização e políticas públicas, como as feiras, o PNAE, etc.

Pode-se considerar que o PAA se revela como responsável no distanciamento dos atravessadores na mediação da produção, por proporcionar uma maior visibilidade e estimulo ao desenvolvimento da agricultura familiar e pelo acréscimo na renda das famílias, no entanto, o processo burocrático ainda dificulta a inserção de um número maior de agricultores.

Mesmo que nos dados analisados tenha ocorrido um aumento no valor dos recursos das associações de Lagoa Seca, o número de agricultores participantes ainda é ínfimo diante do universo de agricultores familiares do município (35 de um total de 1.592 estabelecimentos agrícolas familiares identificados pelo IBGE no Censo Agropecuário de 2006). Além do mais, esses agricultores estão ligados a quatro associações de agricultores, quando a área rural do município esta dividida em 33 comunidades.

O PAA demonstra um caráter inovador e estratégico, ao buscar simplificar e agilizar o escoamento da produção; promover e ampliar a inserção socioeconômica dos agricultores familiares; disponibilizar alimentos adequados à nutrição das populações em 
situação de vulnerabilidade social e insegurança alimentar; habilitar os agricultores familiares para controlar a comercialização de seus produtos, o que resulta no aumento real de suas rendas e no abandono de uma relação de desvantagem com os atravessadores.

Todavia, os aspectos burocráticos, a morosidade entre a finalização de um projeto e o início do outro e os problemas com o pagamento advertem que algo precisa ser revisto para que o programa possa dar mais condições de execução e de uma participação mais ampla. O PAA desburocratiza o mercado institucional ao eliminar o processo licitatório, contudo, em sua execução, a burocracia continua sendo uma barreira.

O mercado institucional pode se configurar como um mercado promissor para a agricultura familiar, mas tem que respeitar o potencial produtivo dos agricultores dando capacidade para seu progresso socioeconômico. Tais implicações se aproximam das considerações de Gomes (2012), em seu artigo sobre Políticas Públicas para o Semiárido, ressaltando que é preciso atentar para o fato de que, em certos contextos, os arranjos institucionais ainda carecem de aperfeiçoamento e as formas de regulação e de institucionalidades ainda são insuficientes e pouco eficazes no sentido de intervir na reprodução da desigualdade. 


\section{Referências}

COMPANHIA NACIONAL DE ABASTECIMETO - CONAB. Programa de Aquisição de Alimentos.Legislação Básica. 2011.

COSTA, Islândia Bezerra da. "Nessa terra, em se plantando tudo dá?" Política de soberania e segurança alimentar e nutricional no meio rural paraense : o caso do PAA, 2010, 2010.

DELGADO, Nelson Giordano ; LEITE, Sérgio (org.). Políticas econômicas, ajuste externo e agricultura. In.: Políticas públicas e agricultura no Brasil. Porto Alegre: UFRGS, 2001.

FARIA, Carlos A. P. de. «Idéias, conhecimento e políticas públicas: um inventário sucinto das principais vertentes analíticas recentes». Revista Brasileira de Ciências Sociais. São Paulo, v.18, n.51, p.21-29, fev. 2003.

GOMES, Ramonildes Alves, o Semiárido brasileiro na perspectiva de instituições e organizações não governamentais (ONGs): Políticas Públicas para o Semiárido: uma visão crítica. Apresentação oral no seminário PROCAD. Campina Grande, 2012.

GRISA, C. et al. O Programa de Aquisição de Alimentos (PAA) em perspectiva: apontamentos e questões para o debate. Rio de Janeiro: OPPA/UFRRJ/ActionAid, , 24p., 2009.

HANKIVSKY, Olena. Intersectionality and public policy: Some Lessons from Existing Models. Political Research Quarterly, Aug, 25, 2010.

IBGE- Censo agropecuário 2006. Agricultura Familiar. Primeiros resultados. Brasil, Grandes Regiões e Unidades da Federação. MDA/ MPOG, 2009. Disponível em: http://www.ibge.gov.br/home/estatistica/economia/agropecuaria/censoagro/2006/agropecuario.pdf. 
, Censo demográfico 2010. Disponível em: http://www.ibge. gov.br/censo2010/primeiros_dados_divulgados/index.php?uf=25.

MINISTÉRIO DO DESENVOLVIMENTO SOCIAL E COMBATE À FOME. Disponível em: http://www.mds.gov.br/segurancaalimentar/ alimentoseabastecimento/paa

MINISTÉRIO DO DESENVOLVIMENTO SOCIAL E COMBATE À FOME. Programa de Aquisição de Alimentos - PAA - compra direta local da agricultura familiar - CDLAF - Manual de orientação ao proponente. Nov, 2004.

OLIVEIRA, Dalila Andrade. Das políticas de governo à política de estado: reflexões sobre a atual agenda educacional brasileira. Educ. Soc., Campinas, v. 32, n. 115, p. 323-337, abr/jun, 2011. Disponível em: http://www.cedes.unicamp.br

SCHIMITT, Cláudia Job; GUIMARÃES, Leandro Alonso. O mercado institucional como instrumento para o fortalecimento da agricultura familiar de base ecológica. Agriculturas, v. 5, n. 2 , jun./2008. 


\title{
VI
}

\section{Nas Redes do Movimento de Organização Comunitária (MOC): um estudo do programa de aquisição de alimentos (PAA) na região sisaleira da Bahia}

\author{
Jaqueline da Luz Ferreira ${ }^{52}$ \\ Patrícia dos Santos Pinheiro ${ }^{53}$
}

A proposta do artigo $^{54}$ é descrever e refletir sobre o papel das redes associativas do Território do Sisal ${ }^{55}$ da Bahia no complexo pro-

52 Bacharela em Ciências Sociais, mestra em Ciências Sociais (CPDA/UFRRJ) e doutoranda em Ciências Sociais. Bolsista CNPq. Programa de Pós-graduação de Ciências Sociais em Desenvolvimento, Agricultura e Sociedade (CPDA/UFRRJ). jaquelineluzferreira@gmail.com.

53 Tecnóloga em Meio Ambiente, mestra em Desenvolvimento Rural (PGDR/UFRGS), doutoranda em Ciências Sociais. Bolsista CNPq. Programa de Pós-graduação de Ciências Sociais em Desenvolvimento, Agricultura e Sociedade (CPDA/UFRRJ). patriciasantspinheiro@gmail.com

54 Este artigo apresenta parte dos resultados da pesquisa Políticas em Rede: uma análise comparativa das interdependências entre o Programa de Aquisição de Alimentos e as redes associativas na Bahia e no Rio Grande do Sul coordenada pela Professora Cláudia Job Schmitt (CPDA/UFRRJ), o Professor Jorge Romano (CPDA/ UFRRJ) e o Professor Marcelo Kunrath Silva (PGDR/UFRGS) e desenvolvida junto às suas respectivas equipes de pesquisa. A referida pesquisa teve como objeto de análise as interações que se estabelecem entre atores da sociedade civil e agentes governamentais no processo de implementação do Programa de Aquisição de Alimentos considerando contextos locais distintos e formas de operacionalização específicas (SCHMITT et al., 2012).

55 O Território do Sisal é um Território de Identidade delimitado pelo poder público estadual. A criação dos Territórios da Identidade é parte do processo mais recente 
cesso de operacionalização do Programa de Aquisição de Alimentos. Considerando a crescente incorporação de organizações sociais na implementação de políticas e programas governamentais, coubenos olhar as estratégias destes atores para discorrer sobre estas novas atribuições.

Segundo dados do Sistema de Informações Territoriais ${ }^{56}, 582.331$ habitantes compõem a população total do Território do Sisal, distribuídos em vinte municípios (ver Figura 1- mapa Território Rural do Sisal). Neste Território, que possui Índice de Desenvolvimento Humano (IDH) médio de 0,60, segundo os mesmos dados, há 58.238 agricultores familiares, com 2.482 famílias assentadas, duas comunidades quilombolas e uma terra indígena.

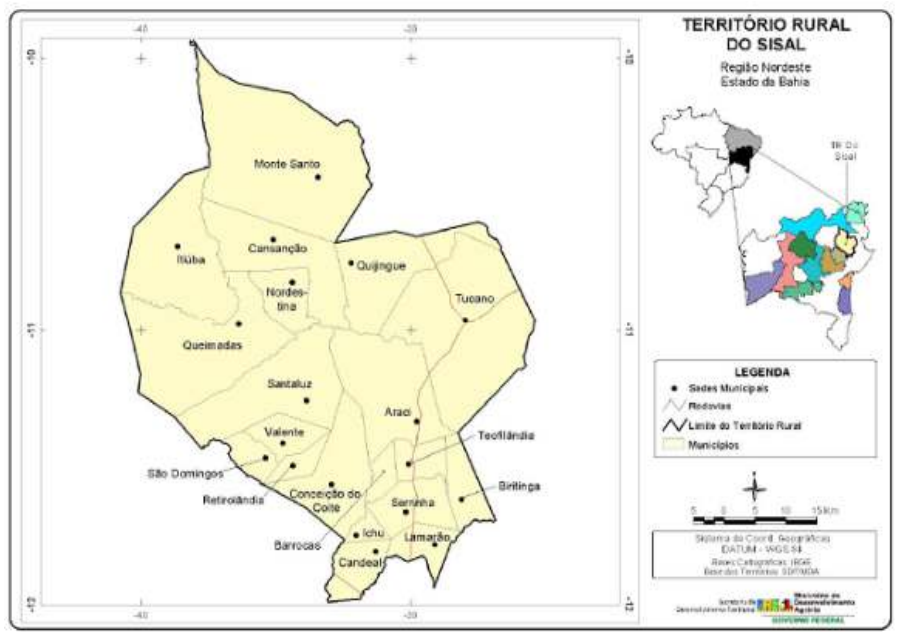

Figura 1- Mapa Território Rural do Sisal

Fonte - Sistema de Informações Territoriais (Disponível em: <http://serv -sdt-1.mda.gov.br>) apud Lima (2008).

de regionalização para o planejamento do estado da Bahia, a partir da instituição de novas diretrizes adotadas pelo poder público, que tinham por objetivo uma melhor integração das políticas públicas com as realidades locais, em 2003 foram mapeados em todo o estado da Bahia os referidos territórios (DI LAURO et al., 2009). Utilizamos neste arquivo o termo território para se referir a esta delimitação política realizada pelo governo da Bahia.

56 Disponível em: <http://sit.mda.gov.br>; acesso em 14 dez 2011. 
Uma questão relevante para o Território do Sisal é a convivência em um ambiente físico marcado pela semiaridez. O semiárido é um ecossistema caracterizado pela distribuição irregular da chuva, com longos períodos de estiagem e baixo índice pluviométrico em comparação com o restante do país, e com a presença de vegetação de caatinga (CIRILO, 2008). Neste local, produções agropecuárias mais adaptadas às limitações climáticas estão presentes atualmente: o sisal, a pecuária e a agricultura de subsistência (MOC, 2009). Porém, a forma como essas produções se desenvolvem assumem estratégias e arranjos singulares, dado que a questão das limitações climáticas não é o único fator que influencia a sua configuração.

Além do entendimento da configuração ambiental, o contexto sociopolítico e institucional precisa indubitavelmente ser levado em consideração quando analisamos a agricultura familiar do Território. Se por um lado, a convivência com o semiárido se torna difícil em função dos mecanismos de estímulo à exploração predatória dos recursos naturais enquanto modelo de agropecuária, por outro, os processos de marginalização das populações locais agravam esse quadro. Ao longo dos anos, a convivência com o semiárido se tornou uma questão mais grave devido às práticas assistencialistas historicamente adotadas pelos representantes políticos na região. Por um lado, enfatiza-se a falta de acesso da grande maioria da população a direitos básicos, como educação de qualidade e infraestrutura e, por outro, a dimensão moral de difusão de uma imagem de inviabilidade do convívio com o semiárido (BATISTA, s/d; MALVEZZI, 2007).

Apesar das dificuldades enfrentadas, muitos atores têm se destacado na formação de um rico tecido organizativo geograficamente descentralizado no âmbito do Território, no qual, a agricultura familiar, predominante no perfil da região ${ }^{57}$, atua de

57 Há um significativo número de pequenas propriedades no Território do Sisal, muitas das quais se constituem de minifúndios e não possuem o título legal da terra. Freixo, Teixeira e Laranjeira lembram que, em diversos casos, o fracionamento das propriedades é tal que inviabiliza a reprodução social da família somente a partir da atividade agropecuária, gerando "excedente de mão-de-obra, principalmente 
maneira singular, tendo o associativismo e o cooperativismo como práticas importantes.

Concentram-se na região Sisaleira diversas organizações e instituições vinculadas à agricultura familiar, tais como: associações de agricultores, cooperativas de produção e comercialização, cooperativas de crédito, sindicatos de trabalhadores rurais, organizações sindicais de caráter regional (polos sindicais), movimentos sociais, organizações não governamentais, como o Movimento de Organização Comunitária (MOC) e a Agência Regional de Comercialização do Sertão da Bahia (ARCO SERTÃO), e centrais de cooperativas, a exemplo da União das Cooperativas da Agricultura Familiar e Economia Solidária (UNICAFES) e da Fundação de Apoio aos Trabalhadores Rurais e Agricultores Familiares da Região do Sisal e Semiárido da Bahia (FATRES). Também está presente o Movimento de Mulheres Trabalhadoras Rurais (MMTR). Destaca-se ainda a atuação de diversos conselhos, estaduais e nacionais, e das igrejas, como exemplo, as pastorais vinculadas à Igreja Católica.

Ante a este mosaico de atores coletivos e plurais, a pesquisa que subsidiou as reflexões que serão apresentadas, neste artigo, adotou como recurso analítico a rede de organizações articulada pelo MOC. Isso porque o MOC é uma das mais antigas organizações da região, e como mostraremos adiante, tem papel importante na criação e no fortalecimento de outras organizações dentro desta rede, a partir de sua relação com os agricultores e outras organizações da região que a referida pesquisa desenvolve-se.

O MOC foi o ponto de partida da pesquisa. Foi por meio dessa organização que pudemos perceber alguns dos caminhos que o PAA percorreu para chegar até os agricultores e as comunidades do Território do Sisal. Porém, embora reconheçamos que o MOC tem grande peso no fortalecimento da agricultura familiar e do associativismo em uma área de abrangência que inclui além dos municípios do Território do Sisal, também os municípios dos Territórios vizinhos (Território da Bacia do Jacuípe, Território Piemonte da Diamantina e Território do Portal do Sertão), temos

de jovens, o que contribui para o acirramento da pobreza" (FREIXO ; TEIXEIRA; LARANJEIRA, 2007, p.5). 
o cuidado de esclarecer que não há centralização dos processos analisados em uma única organização da região. Mas, trata-se apenas de reconhecer que o MOC contribuiu decisivamente para nossa entrada no campo de pesquisa.

\section{OMOC: Fragmentos de uma história}

O Movimento de Organização Comunitária surge como um braço da Igreja Católica em seu trabalho social ainda em 1967, com sede no município de Feira de Santana. O fundador foi o padre Albertino Carreiro que, na época, fora indicado para trabalhar em uma paróquia que congregava os bairros mais pobres de Feira de Santana (ALBERTINO, 2007). O apoio de assessores da Federação de Órgãos para a Assistência Social e Educacional (FASE), também, responsável pelos primeiros recursos financeiros operados pela organização, foi essencial nesta época.

Na publicação MOC na linha do tempo, editada pelo próprio MOC, a década de 1960 é descrita como um momento de firmar um posicionamento diferenciado da Igreja frente a populações carentes. 0 desafio maior, naquele momento, consistia em mudar de uma postura confessional para uma postura ecumênica (MOC, 2007). Por sua vez, a entrada nas comunidades através da Igreja propiciou ao MOC capacidade de mobilização mesmo no período da ditadura. 0 trabalho de organização comunitária neste momento, embora incipiente, tentava discutir e resolver os problemas imediatos destas comunidades no sentido de fazer com que as pessoas passassem a se perceber como agentes da sociedade em que vivem (MOC, 2007).

A década de 70 foi marcada pelo aumento da repressão do regime militar, assim como pela perseguição ao MOC dentro da Igreja. É neste momento que o MOC se torna uma entidade autônoma, não mais submetida à Igreja Católica, embora ainda trabalhando em parceria com as dioceses locais. Já na década de 1980, diferenciamse e consolidam-se as linhas de ação da organização: a educação popular, o fortalecimento do comunitarismo (fomento a hortas, criatórios, roças, saúde, organização, etc), o fomento a iniciativas com agricultura orgânica, a criação de fundos rotativos de apoio 
às unidades produtivas, o incentivo às organizações de mulheres, a participação nos sindicatos e na mobilização em torno de lutas específicas (MOC, 2007). A busca de alternativas para a convivência com o semiárido é um elemento que perpassa estas ações. Segundo Paixão (2006), no fim da década de 1990, pode-se perceber que as ações do MOC passam da reivindicação e fiscalização política para a proposição e negociação de políticas públicas. E o momento da Constituinte de 1988 é tido como o início de uma série de ações de proposição ao poder público, fruto da possibilidade de participação da sociedade civil na gestão pública, especialmente nos processos de definição dos marcos legais e na participação de conselhos (PAIXÃO, 2006; MOC, 2007). O início da década de 1990 foi marcado, pela instrumentalização dos movimentos sociais locais a interferirem nas ações do poder público.

Analisando os relatórios anuais do MOC e outras publicações, encontra-se uma reflexão da organização relacionada a sua forma de atuação frente às políticas públicas. Tal reflexão aponta para ações de potencialização das demandas das comunidades locais, o estímulo à representação em espaços nos quais as políticas são construídas e à participação direta dessas comunidades junto à execução das políticas públicas criando mecanismos para o seu acesso contínuo.

Passados alguns anos, O MOC se qualifica quanto ao tipo de intervenção e gestão direta da organização frente às políticas públicas, o que acaba tendo um caráter transversal nas ações de assessoria a grupos populares desenvolvidas pela organização. Por exemplo, colocada a necessidade de ocupar os espaços de proposição e elaboração de políticas públicas, traz-se também a importância em assessorar os grupos a sistematizarem suas práticas, para que consigam elaborar políticas, que atendam as diferentes necessidades (MOC, 2009).

Percebe-se que o fortalecimento e a institucionalização do MOC ocorrem no processo de redemocratização da sociedade brasileira, assim como aconteceu com diversas outras organizações sociais (SCHMITT et al., 2012). Essa institucionalização, por sua vez, se faz cada vez mais próxima das ações públicas governamentais, em seus diversos níveis. Por um lado, porque a própria organização 
procurou ocupar os espaços de reivindicação e proposição frente ao poder público e, por outro, porque houve um reconhecimento por parte da sociedade e dos poderes públicos do papel desempenhado pelo MOC na região do semiárido baiano.

É interessante ressaltar que, neste processo, houve uma crescente e contínua inserção das políticas públicas governamentais nos próprios objetivos e linhas de ação do MOC, assim como cresceu o número de experiências em que a organização implementou diretamente políticas públicas - como foi o caso do Programa de Erradicação do Trabalho Infantil (PETI), a partir de 1996, e atualmente o caso da política de assistência técnica e extensão rural.

Entre as mudanças vivenciadas no curso da sua trajetória, o MOC experimentou alterações nas formas de financiamento e captação de recursos. Tradicionalmente, parte dos recursos que financiavam as ações do MOC advinha da cooperação internacional, especialmente de países como a Holanda, Alemanha, Áustria, Bélgica, Canadá e Estados Unidos (MINIHUBER; BAPTISTA, 2009). De acordo com Minihuber e Baptista (2009), o final da década de 1990 assiste um processo gradual e irreversível de diminuição dessa fonte de recursos, e em contraposição, abrem-se dentro do país, especialmente no poder público, novas fontes de financiamento. Este processo faz com que a década de 2000 mostre uma configuração bem diferente da composição dos recursos da instituição, conforme mencionam os autores: "do total de recursos captados em 2006, por exemplo, 83\% eram provenientes do poder público, enquanto a cooperação internacional correspondia a somente $10 \%$ e as empresas ou fundos privados a 6\%" (MINIHUBER; BAPTISTA, 2009, p. 4).

Essa mudança, no entanto, traz consequências para as organizações financiadas. Nesse sentido, Minihuber e Baptista (2009) mencionam que a dependência do financiamento público trouxe questões que antes não estavam no horizonte da organização, como uma menor flexibilidade no destino dos recursos e a susceptibilidade a alterações na conjuntura política do país. Os autores colocam ainda que ao perceber esta mudança nas fontes de financiamento, o MOC inicia estratégias de diversificação destes, sem, no entanto, deixar de lado as parcerias com o poder público. 
Essa preocupação exposta pelo MOC no que diz respeito à dependência da organização em relação aos seus financiadores parece bastante comum a organizações sociais sem fins lucrativos. Isso porque, para sobreviver, organizações como estas necessitam constantemente buscar contribuições financeiras com governos, instituições do mercado e pessoas físicas. Assim como os financiadores privados (empresas, indivíduos) e públicos buscam tais organizações para atingirem determinados objetivos, o que revela uma relação de interdependência. No caso dos governos, torna-se cada vez mais comum que se estabeleçam parcerias com organizações da sociedade civil nos processos de formulação e gestão de programas públicos (SCHIMITT et. al., 2012).

A estratégia anunciada no documento do MOC de diversificação das fontes financiadoras, por exemplo, traz principalmente a preocupação de uma dependência exclusiva de governos. De acordo com seus relatórios, parece central para a organização manter a independência de suas ações frente ao Estado. Sobre este aspecto, é interessante observar as análises de Giugni e Passy (1998) que entendem a relação entre organizações da sociedade civil e o Estado enquanto processos que resultam, ao mesmo tempo, de iniciativas de ambos os atores. Se, por um lado, as organizações sociais procuram expandir os canais de acesso ao Estado como forma de alcançar seus objetivos políticos (seja acesso a mais recursos, formulação de leis, políticas, ou mesmo mudanças institucionais), por outro, os governos se deram conta de que as organizações sociais, por possuírem um histórico de atuação especializado em uma determinada área ou questão, possuem também informações valiosas para a ação pública, por isso a importância da atuação conjunta com estas organizações (GIUGNI ; PASSY, 1998). Entretanto, Giugni e Passy (1998) destacam que esta relação que se estabelece a partir de então entre o Estado e a sociedade civil não se dá sem conflito, em especial, quando falamos de transferência de responsabilidades do Estado e suas agências para organizações da sociedade civil, como ocorre com o Programa de Aquisição de Alimentos.

Também pensando sobre estes processos, Cohen e Arato (2000) reconhecem que a inclusão das organizações sociais nos processos administrativos do Estado (como a execução de uma política 
pública) resulta, de certa forma, em uma rotinização de suas ações. Entretanto, os autores entendem que isso não necessariamente significa que as organizações sociais devam abandonar as ações coletivas de massas, as associações de base, a criação do poder local e políticas mais específicas. Para os autores, a luta pela ampliação do controle sobre as ações do Estado constitui um tipo de ação inerente aos atores coletivos contemporâneos, que a travam tendo consciência de suas possibilidades:

Os atores coletivos contemporâneos lutam conscientemente pelo poder, para construir novas identidades, para criar espaços democráticos tanto dentro da sociedade civil como do sistema de organização política, para a ação social autônoma e para reinterpretar as normas e reconformar as instituições. (COHEN; ARATO, 2000, p. 572)

A experiência do MOC e seus parceiros é significativa no sentido que aponta Cohen e Arato (2000). Para o MOC, a forma de operacionalizar a política passa necessariamente por estratégias e arranjos locais, em que estão envolvidas as organizações da sociedade civil. Tais arranjos são parte da construção destas políticas públicas e as viabilizam e, quando não existem ou são mal conduzidos e definidos, estabelece-se uma barreira no acesso dos grupos sociais às políticas públicas (MOC, 2009). Essas estratégias e arranjos locais expressam a ação dos atores locais/regionais (organizações) que se inserem nesta rede. Uma das suas características é o fortalecimento dos agricultores e suas organizações através, por exemplo, do fomento ao cooperativismo, a comercialização e a organização das mulheres.

\section{A Rede do MOC}

O que estamos chamando aqui de rede do MOC diz respeito exatamente à forma de articulação de diversas organizações nas ações desenvolvidas pela própria instituição. As organizações (cooperativas, associações, grupos produtivos, etc) que são assessoradas pelo 
MOC passam a ter contato e fazer parte de uma rede articulada de organizações, em nível regional, estadual, federal e internacional - tais como ONGs, universidades, agências estatais, fóruns de articulação social, empresas públicas e privadas, movimentos sociais, sindicatos, cooperativas de crédito, assistência e comercialização, entre outras. Ou seja, os empreendimentos assessorados pelo MOC passam também a receber apoio de grande parte dos seus parceiros, o que envolve o compartilhamento de experiências entre as organizações. Assim, a atuação em rede se constitui como uma estratégia de ação em que as políticas públicas governamentais acabam se utilizando para chegar aos agricultores da região.

É importante destacar que algumas destas organizações locais e regionais surgiram a partir do trabalho desenvolvido pelo MOC, diante das demandas geradas entre as comunidades, técnicos e lideranças. A ARCO SERTÃO, a REPARTE e, mais recentemente, a COOPEREDE são exemplos. Segundo uma técnica do MOC entrevistada na pesquisa, estas organizações surgem como apoio ao trabalho das organizações locais, como por exemplo, a ARCO SERTÃO, que foi criada com o objetivo de fortalecer e buscar alternativas para as experiências de comercialização na região. A ARCO SERTÃO é uma associação formada por 30 empreendimentos solidários dos Territórios Bacia do Jacuípe, Sisal e Portal do Sertão, atuando diretamente com cerca de 2.500 agricultores familiares, segundo o site da ARCO SERTÃO ${ }^{58}$

A COOPEREDE tem parceria com o Movimento de Mulheres Trabalhadoras Rurais (MMTR), movimento presente desde a década de 80, na região, atuando com a representação política das mulheres trabalhadoras rurais. Atualmente, ela está constituída por 55 grupos, a grande maioria ainda informais, localizados em 25 municípios da Bacia do Jacuípe, Portal do Sertão e (principalmente) no Sisal.

58 Disponível em: <http://www.arcosertao.org.br/>. Acesso em setembro 2011. As cooperativas vinculadas a ARCO SERTÃo formaram, em 2011, a Central de Cooperativas de Comercialização da Agricultura Familiar do Estado da Bahia (ARCO Central), cuja sede própria está sendo construída em Serrinha e abrigará também uma central de comercialização da organização. 
Especificamente em relação ao PAA, O MOC trabalha diretamente no sentido de assessorar as organizações no acesso e implementação do Programa, assim como promovendo seminários sobre o tema, seja para avaliação ou para capacitação, bem como reuniões. Nesse sentido, a técnica do MOC descreve esta estratégia de atuação em parceria com outras organizações de assessoria, a partir da troca de informações, experiências e outras formas de apoio:

No subprograma de acesso ao mercado, a gente tem como linha de atuação trabalhar com duas organizações, de nível regional, que é a ARCO SERTÃo e a Rede [COOPEREDE], que estes empreendimentos estão filiados. (...) E na Rede e na ARCO, nas atividades coletivas, que a gente faz bimensalmente, a gente trata do PAA, e então tem um nivelamento ali de informação, de conhecimento entre os empreendimentos, e na maioria dos empreendimentos que fazem parte da Rede e da ARCO, quase todos, eu digo, praticamente todos os empreendimentos hoje já têm acesso a essa política (...), empreendimento de processamento de alimento já fazem parte da política, a mesma coisa da Rede, os grupos de mulheres se organizam, buscam suas associações comunitárias lá, e lá tem acesso à política (Técnica do PFAF do MOC, outubro de 2011).

Essas organizações também estimulam a capacitação dos grupos, buscando a sua participação em projetos em parceria com outras organizações, conforme relato de uma das lideranças da COOPEREDE:

Então é assim, o produto não tá muito bom, aí consegue um projeto pra melhorar a produção, que a gente tem capacitado. A gente começou muito na área do artesanato, depois a gente 
foi sentindo necessidade, porque artesanato é época, né, às vezes vendia e época não vende... Daí assim, a rede, junto com o MOC, porque o MOC tem sido um parceiro muito forte, acho que tudo isso chegou através do MOC... (Liderança da COOPEREDE, outubro 2011).

Quando uma cooperativa ou associação de agricultores passa a receber a assessoria do MOC, esta também se insere no âmbito do planejamento e ação de diversas outras organizações diretamente. Um exemplo disso é o fato de que todos os empreendimentos da agricultura familiar assessorados pelo MOC estão filiados à ARCO SERTÃO. Da mesma forma, os grupos produtivos de mulheres que são assessorados pelo MOC, além de estarem filiados à ARCO SERTÃO, estão também associados à COOPEREDE. Os empreendimentos assessorados passam também a receber apoio de grande parte dos seus parceiros, inserindo-se em uma rede de organizações de assessoria, na qual são compartilhadas experiências, com o intuito de fortalecer as organizações locais:

(...) tem uma demanda maior, fora dessas redes, que são os empreendimentos, e o PAA vem fortalecendo também essas duas redes. O empreendimento que tá fora dessas redes, a gente fala: "olha vocês vão ter um acompanhamento técnico ao se filiar a alguma dessas redes que a gente faz o acompanhamento, não sistemático ainda, porque a gente não tem projeto pra acompanhar vocês, mas um acompanhamento bimensal de orientação, de informação, vocês vêm participando das redes". Aí muitos começaram a se filiar aos dois empreendimentos, e acaba fortalecendo essas redes, e os próprios empreendimentos (Técnica do PFAF do MOC, outubro de 2011). 
Neste sentido, o MOC atua fortalecendo as organizações que fazem parte desta rede, a partir da troca de informações, experiências e outras formas de apoio. E neste processo, o PAA se torna uma importante via de articulação:

$\mathrm{Eu}$ acho que é a metodologia que assim vem mesmo avançando, não fica naquela coisa bem pequena, fechada ali, vem ampliando mesmo no território do Sisal e Bacia do Jacuípe (...). Que a gente acredita que um empreendimento feito lá no município, separadamente, pode até tá acessando PAA, mas vai ter muita dificuldade na qualificação, na apresentação do produto, no acesso a outros mercados, até mesmo a continuidade naquele mercado, e aí cabe às redes também ter os instrumentos de estruturação (Técnica do PFAF do MOC, outubro de 2011).

Dessa forma, trabalhando em rede, há a possibilidade de assessorar, mesmo que de forma pontual, um maior número de organizações, bem como possibilita articulações que fortalecem mutuamente os grupos. Um exemplo de estruturação mencionado pela técnica é o uso de um fundo rotativo acessado pelos empreendimentos vinculados a ambas as organizações, no qual, estabelece-se uma metodologia para fortalecer os empreendimentos se utilizando desta rede de organizações. É também a partir da inserção nesta rede que as organizações são apresentadas a outras políticas, como foi o caso do PNAE (Programa Nacional de Alimentação Escolar), e projetos, como o do Consulado de Mulheres $^{59}$, que possibilitou a compra de equipamentos e maquinários para os empreendimentos.

59 o Consulado da Mulher é uma ação social da marca CONSUL voltada para mulheres de baixa renda com o objetivo de fomentar a geração de renda e melhoria de qualidade de vida de suas famílias. Para tanto assessora empreendimentos populares protagonizados por mulheres. 
Essa metodologia de ação em rede, para a técnica do MOC que entrevistamos, é o diferencial do Território do Sisal e da Bacia do Jacuípe. No entanto, a técnica admite que devido a este número grande de organizações na rede, o monitoramento do andamento dos empreendimentos acaba sendo limitado:

A gente sempre monitora, mas é bem precário mesmo, viu? Muitos empreendimentos na região já tocam os seus projetos só, isto a gente não tem como acompanhar. Final de ano, aí a gente tem um relatório anual do MOC, aqueles empreendimentos que são meta do programa acompanhar são monitorados (Técnica do PFAF do MOC, outubro de 2011).

Nesse sentido, estão envolvidos na rede muito mais organizações do que aquelas que o MOC assessora oficialmente. E o número certo de organizações que recebem informações e compartilham da experiência desta rede não é registrado.

Considerando a assessoria prestada pelo MOC e outras organizações da rede como fundamentais para que os agricultores acessem o PAA, é também colocada a necessidade de articulação desta política com a Política Nacional de Assistência Técnica e Extensão Rural - ATER. Por mais que o MOC receba recursos da ATER para prestar o serviço, não são todas as organizações de agricultores que estão em sua rede que são contempladas pela política da ATER. Para a técnica do MOC, essa articulação entre o PAA e a ATER é fundamental para a continuidade de acesso dos agricultores ao Programa:

O PAA eu vejo assim que é uma política mesmo bem forte comparada às outras, mas que veio como complemento, então se não tivesse uma ATER a gente não estava com essa produção um pouco organizada para o acesso ao mercado, então vem a complementar no acesso. O PAA tem que vir casado com a política de acompanhamento e assistência técnica na 
área da gestão, da organização, da produção e gestão (Técnica do PFAF do MOC, outubro de 2011).

Um elemento importante mencionado pela técnica é que o modo de organização da ATER deve contemplar a organização coletiva dos agricultores, não apenas suas iniciativas individuais:

Um agricultor não vai entregar um feixe de hortaliça pro PAA, não, ele tem que tá organizado, organizado em empreendimento, ele tem que conhecer todo esse trabalho dinâmico que é uma economia solidária, todas essas temáticas pra acesso ao mercado. Então eu vejo que há um grande desafio aí para o programa é ter uma política de assistência técnica com esse viés, voltada, casada junto com o PNAE, com o PAA, porque é outra dimensão né, não é a dimensão de produção individual, mas é dimensão assim mais da organização, é tirar da cabeça do agricultor que ele tá sozinho, isoladamente não vai. (Técnica do PFAF do MOC, outubro de 2011).

No seu entendimento, a assessoria prestada às unidades produtivas, como é comum nos serviços da ATER, não atende a demanda das organizações, visto que os problemas de gestão de um programa como o PAA precisam de uma assessoria específica a estas organizações. Na medida em que a política de assistência técnica é formatada para atender o agricultor individualmente, os problemas da organização ficam de fora.

Além do MOC, há uma série de outras organizações que prestam os serviços de ATER (com recursos públicos ou não) no Território do Sisal, que também estão em contato nesta rede, tais como a ARCO SERTÃO, a Fundação APAEB Valente, APAEB Serrinha, a ASCOOB, a UNICAFES, a FATRES, entre outras. Uma parte destas organizações de assessoria é filiada à Rede de Parceiros da Terra 
(REPARTE). A REPARTE surgiu, em 2004, com o objetivo de assessorar suas filiadas na gestão de programas e projetos, atuando em oito outros Territórios de Identidade, para além do Território do Sisal. A REPARTE atua, sobretudo, no sentido de qualificar suas filiadas na prestação de um serviço de ATER pública não estatal descentralizada e de qualidade. Embora na chamada pública da PNATER, cada organização desta seja responsável por determinadas comunidades e famílias, o esforço parece ser o de circular informações e experiências nesta rede.

Considerando esta rede de organizações parceiras que atuam no Território e, para além deste, fomentando a agricultura familiar, parece ser importante ressaltar algumas características em comum, que possam identificar o trabalho desta rede, em relação às formas de acesso ao PAA no Território do Sisal.

\section{OPAA no Território do Sisal}

É no início da década de 2000, que a rede de organizações articulada pelo MOC começa a discutir a economia solidária e a pensar formas de fomentar a produção e comercialização dos agricultores e agricultoras familiares do semiárido baiano. Concomitantemente, começam a surgir grupos interessado em agregar valor a sua produção, muitos deles fomentados por políticas públicas. É neste momento, também, que surge o Programa de Aquisição de Alimentos, passando a fazer parte das ações da rede mobilizar os empreendimentos para acessar o Programa - PAA.

Segundo uma técnica do MOC, o primeiro empreendimento assessorado pelo MOC que acessou o Programa foi o Centro São João de Deus no município de Ichu, com um projeto de $\mathrm{R} \$ 40.000 .00$, envolvendo cerca de 30 agricultoras. Aos poucos, a experiência foi compartilhada e outros empreendimentos passaram a participar do Programa. A mesma técnica, quando entrevistada, falou de uma resistência inicial dos agricultores devido ao caráter inovador e complexo do formato do Programa. Segundo seu relato, muitos agricultores não acreditavam na possibilidade de vender seus produtos para o governo e posteriormente doá-los para as 
comunidades da região, operação necessária pela modalidade do Programa que é majoritariamente acessada na região: a Compra Direta com Doação Simultânea ${ }^{60}$.

A estratégia inicial do MOC, segundo esta técnica, foi potencializar as associações e cooperativas de agricultores já existentes, ao invés de criar novas. Na sua visão, o Programa acabou possibilitando a reestruturação de algumas cooperativas e associações formadas nas décadas anteriores, como resultado de diferentes ações de organização comunitária, que estavam paradas devido à falta de estímulo e de oportunidades para seu funcionamento permanente.

A primeira organização do Território do Sisal a acessar o PAA, ainda em 2003, foi a APAEB do município de Valente. Nos primeiros anos, o Programa era pouco conhecido e, consequentemente, um número reduzido de organizações o acessavam. De lá para cá, 3841 agricultores já acessaram o PAA, conforme gráfico a seguir.

60 A partir da pesquisa, pôde-se verificar que a modalidade Compra Direta com Doação Simultânea é a mais acessada no estado da Bahia. Uma das explicações para este fato se encontra na própria trajetória de implementação do Programa no estado, que contou muito mais com o envolvimento de organizações da sociedade civil com atuação regional e estadual junto aos agricultores familiares do que com o envolvimento do governo do Estado e das prefeituras. As redes associativas existentes no Estado foram fundamentais para a articulação política e disseminação do Programa nos municípios. De acordo com SCHIMITT et. al. (2012), no período inicial de implementação do programa, verifica-se um envolvimento muito tímido do Governo estadual, quadro que irá se modificar consideravelmente com a eleição de Jaques Wagner do Partido dos Trabalhadores para o governo do estado da Bahia em 2006. Algumas ações do governo do PT a partir de então, por meio da Secretaria de Desenvolvimento Social e Combate à Pobreza, contribuíram para a expansão do programa no estado e envolvimento de outros agentes públicos como as prefeituras. 


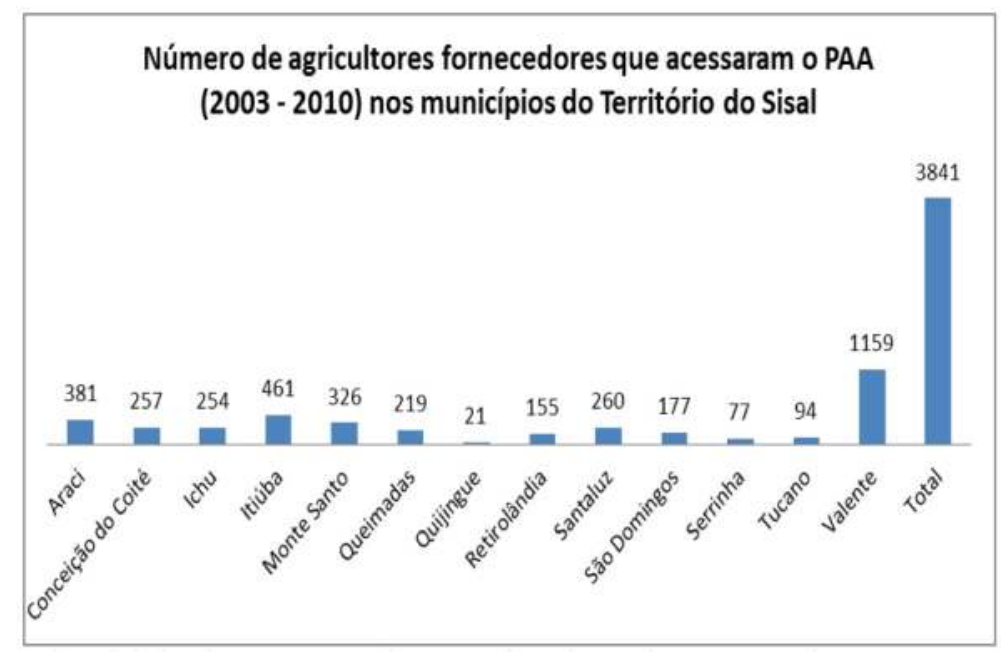

Gráfico 1 - Número de agricultores fornecedores que acessaram o PAA (2003-2010) nos municípios do território do sisal

Fonte - dados da CONAB/2010

Segundo os dados da CONAB (datados de 2010), 46 organizações tiveram participação no Programa, das quais, 32 são associações de agricultores e nove são cooperativas. Estas associações são comunitárias, locais, tendo apenas parte de seus associados acessando o PAA. Em vários casos, os agricultores e agricultoras das associações formam grupos produtivos dentro da própria organização, como é o caso do grupo de mulheres PROSPERAR da Associação Comunitária Bastianense e o grupo Sabor Gama, da Cooperativa M. de Produtores de Gameleira, ambas do município de Retirolândia (BA).

O relato de uma agricultora associada à COOPEREDE demonstra essa relação: "os grupos são das associações, das comunidades. Os grupos andam por conta da associação, porque a associação é que é legalizada, tem CNPJ e tal, então para o grupo andar, precisa dela, na frente" (informação verbal).

O acesso destas organizações ao PAA, entretanto, não foi contínuo. Só a partir de 2007 é que o Programa foi efetivamente difundido e implementado no Território. Exatamente o mesmo ano 
em que a técnica do MOC aponta como definitivo para a entrada do Programa nas linhas de ação da organização. Porém, para possibilitar essa difusão das propostas a partir de 2007, foram necessárias diversas articulações, debates e esclarecimentos anteriores. No relato de uma liderança da COOPEREDE, 2005 foi o ano em que teve início o processo de inserção das entidades do Território no PAA:

Em 2005, então assim a luta não é de agora não, mas é de agora para os que tão chegando agora, mas pra gente que tá dentro, o negócio não tem sido brincadeira, foi mais ou menos um ano de discussões... Para cursos, oficinas, palestras... Para a gente entender que realmente as coisas do governo a gente não entendia como é que era, vendeu, 'mas como é que esse governo vai vim comprar o nosso produto aqui na mão da gente?' Eu sei que foi uma coisa de amadurecimento (liderança da COOPEREDE, outubro 2011).

O diálogo e a aproximação dos agricultores que acessam o PAA com a comunidade local e os beneficiários do Programa também é um fator destacado por esta técnica:

Então assim, não só no acompanhamento, e não é só o empoderamento da parte financeira, mas na parte política e social. Então pessoas que estavam ali na comunidade, só na sua propriedade, hoje já têm uma relação na comunidade, e com outras comunidades, que o PAA tem um grande valor aí no controle social, né? Então, aquele grupo que se organizou tem que tá relacionado com o Conselho de Assistência Social, para dar o laudo, tem que tá relacionado com a vigilância sanitária, tem que se relacionar também com outras comunidades para o recebimento dos produtos (Técnica do PFAF do MOC, outubro de 2011). 
A maioria dos empreendimentos que acessam o PAA são grupos produtivos de mulheres. Com isso, um ponto a ser destacado é a valorização das agricultoras, que relatam a participação constante em viagens para realizar e ministrar cursos, a participação em encontros, seminários, feiras e outros eventos como mudanças positivas para autoestima delas. A técnica do MOC também menciona a questão:

Aquelas mulheres que estavam ali nas suas propriedades, hoje já têm uma relação bem mais ampla e além de tá ali no município, também quando têm os seminários, os encontros que são promovidos pela CONAB elas vão. E vão pra quê? Para debater mesmo essa questão do PAA, "tá bom", "melhorou minha vida, mas precisa melhorar nisso, nisso e nisso". Então são pessoas mesmo que a autoestima se elevou, houve um empoderamento não só financeiro, mas político e social também e isso a gente pode perceber muito forte isso aí (Técnica do PFAF do MOC, outubro de 2011).

O diálogo e aproximação dos agricultores e agricultoras com as comunidades e poderes locais também é um fator destacado por esta técnica. Um exemplo é o relato de que muitas prefeituras passam a conhecer o PAA a partir do trabalho realizado pelas próprias organizações de agricultores proponentes de projetos, quando estas procuram a prefeitura para buscar laudos necessários para o acesso ao Programa. Nesse sentido, a técnica do PFAF menciona a aproximação junto à prefeitura do município de Biritinga, onde atualmente há um grupo de produção que acessa o PAA, feita em função da demanda dessa organização, enquanto proponente, e mediada pelo MOC:

Olhe, em pleno 2011 uma política que já tem quase dez anos e Biritinga não sabia o que era isso, daí a gente teve que ir para o Conselho lá, teve que fazer toda a apresentação, o que 
era essa política, apresentar, falar do site pra eles (...) (Técnica do PFAF do MOC, outubro de 2011).

Para as organizações de agricultores assessoradas pelo MOC e seus parceiros, a informação sobre o PAA também circulava na medida em que os empreendimentos iam acessando o Programa. O papel de divulgação do Programa feito pelas organizações do Território, como a ARCO SERTÃO, a COOPEREDE, contribuiu neste sentido, visto que estes atores mobilizam um número significativo de organizações de agricultores, muitas vezes não acessíveis às agências estatais. Também a partir da inserção nesta rede que as organizações dos agricultores conseguem dialogar com a CONAB. Foram vários os relatos da intermediação do $\mathrm{MOC}$ no diálogo entre a organização proponente do PAA e a CONAB como fundamental para o andamento dos projetos, dado o fato de que sua posição de representante de várias organizações proponentes acaba por facilitar a comunicação e mesmo negociar a resolução de possíveis entraves, tais negociações posteriormente são assumidas pelas associações e grupos locais.

Mesmo reconhecendo uma demanda por assessoria de organizações de agricultores na região que vai além daqueles já atendidos, o esforço é de inseri-los nas redes já existentes, em especial através da ARCO SERTÃO e da COOPEREDE, com objetivo de estimular não somente o acesso a um mercado, mas também os processos de fortalecimento da organização comunitária, como relata a técnica do MOC: “(...) O empreendimento que tá fora dessas redes, a gente fala: 'olha vocês vão ter um acompanhamento técnico, ao se filiar a alguma dessas redes que a gente faz o acompanhamento' (...)". Sobre essa importância da inserção nesta rede, uma liderança da COOPEREDE traz o seguinte relato:

Eu acho que assim, a gente é um dos instrumentos fundamental, né, na questão das organizações, porque desde quando a gente tá trabalhando em grupos, em associação, com pessoas reunidas, eu acho que já é um pontapé 
inicial... Que imagina aí se não tem essas organizações como é que as coisas iam dar certo? (...) E desde lá do agricultor, até chegar na associação, a peça fundamental é o agricultor, porque se ele não produz, essas coisas não anda, né?....Então precisa ter a pessoa que arrasta a enxada lá, pra poder produzir, então as coisas não acontecem, e precisa também ter as entidades, as parceiras, como a gente já citou aí, pra tá lá cobrando e buscando, então assim, eu acho, uma coisa sempre ligada a outra (liderança da COOPEREDE, outubro 2011).

Porém, Schmitt et al. (2012) apontam que, ao mesmo tempo em que o PAA possibilita e estimula, a partir de um novo aporte em termos de recursos, a estruturação das organizações, também há uma reordenação na rotina destas mesmas organizações, que precisam se adaptar às demandas que surgem e aos custos de operacionalização do Programa. 0 aprendizado necessário para dominar os instrumentos de acesso à política emerge sempre nos relatos como algo difícil. Segundo as organizações de agricultores entrevistadas na pesquisa e o próprio MOC que as assessora, a operacionalização dos projetos do PAA exige uma grande capacidade de planejamento da ação por parte das organizações, seja na gestão da qualidade e quantidade dos produtos a serem fornecidos, na gestão dos recursos e prestação de contas, na seleção das famílias beneficiadas, ou mesmo no momento da distribuição de alimentos.

Analisando a relação entre a sociedade civil e o estado, quando dos processos relacionados ao gerenciamento de políticas públicas, Rosemblum e Lesch (2011) ressaltam mudanças no papel das organizações da sociedade civil. Se antes estas organizações, entre as quais destacamos o MOC, eram vistas apenas como representativas de grupos sociais, e como suporte para ações de caridade, agora a estas mesmas organizações, que assumem também funções na execução e implementação de programas públicos, são impostas regras de gerenciamento, prestação de contas, metas e resultados. 
Com isso, são substituídos os militantes por quadros profissionais atuando em funções especializadas (ROSEMBLUM; LESCH, 2011).

A partir da experiência de assessoria do MOC junto a sua rede de parceiros nos empreendimentos, voltados para o acesso ao PAA no Território do Sisal é possível afirmar que houve tanto ampliação, quanto fortalecimento da rede associativa a partir da presença do Programa, ao mesmo que esta articulação foi fundamental e necessária para assegurar a própria implementação do mesmo. Através desta rede, a capacidade de mobilização de recursos e estratégias de ação dos diferentes atores para se inserir no PAA foi substantivamente potencializada.

Por sua vez, a existência do Programa fortaleceu as organizações sociais, articuladas pelo MOC, e em alguns casos reestruturou-as. o Território do Sisal desenvolveu maneiras específicas de acessar esta política e de superar muitas das dificuldades. A atuação dos empreendimentos articulados a uma rede extensa de parceiros (que chamamos aqui de rede do MOC), por exemplo, constitui-se uma estratégia de fortalecimento comunitário, que utiliza o PAA e outras políticas públicas direcionadas para a agricultura familiar como ferramentas para consolidar sua organização e comunidade.

Para fins conclusivos, podemos afirmar que o PAA possibilita o acesso a recursos e parcerias que por sua vez permitem que as organizações proponentes qualifiquem ou ampliem sua atuação, seja com a construção de estruturas físicas, seja com a formação de contatos estratégicos. Porém, a dificuldade de adaptação às regras trazidas pelo Programa também é um dos pontos enfatizados pelas organizações que o acessam. Para as associações de agricultores e cooperativas, muitas das quais ainda estão em busca da sua consolidação enquanto grupos produtivos, é um grande desafio se adequar às exigências contidas nos arcabouços jurídicos e legais, que envolvem códigos com os quais os agricultores não tinham proximidade antes do PAA (SCHMITT et al., 2012). Diante disso, cabe-nos dar maior atenção às redes de assessoria que apoiam as diferentes iniciativas da agricultura familiar, principalmente no que diz respeito ao acesso às políticas públicas, que significa também o acesso a outro universo de práticas e significados. 


\section{Referências}

ALBERTINO, Carneiro. Testemunho de Albertino Carneiro, fundador do MOC. IN: MOC, Movimento de Organização Comunitária. O MOC na linha do tempo: MOC 40 anos. Feira de Santana, 2007.

BAPTISTA, Naidison. A ASA e a mobilização social no no Semiárido. Disponível em <http://www2.mre.gov.br/aspa/semiarido/ data/naidison_baptista.htm>. Acesso em 09 dez 2011.

CIRILO, José Almir. Políticas públicas de recursos hídricos para o semi -árido. Estudos Avançados. 2008, v. 22, n. 63, p. 61-82. Disponível em: <http://www.scielo.br/scielo .php?script=sci_arttext\&pi$\mathrm{d}=\mathrm{S} 0103-40142008000200005 \& \ln \mathrm{g}=\mathrm{en} \& \mathrm{nrm}=\mathrm{iso}>$. Acesso em $10 \mathrm{dez}$ 2011.

COHEN, J. L. ; ARATO, A. Los Movimientos sociales e la sociedad civil. In: Sociedade Civil y Teoria Política. Mexico: Fondo de Cultura Económica. 2000.

FREIXO, Alessandra Alexandre; TEIXEIRA, Ana Maria Freitas; LARANJEIRA, Denise Helena Pereira. Entre a valentia do boi e as fibras do sisal: transformações da ruralidade na Região Sisaleira da Bahia. In: Encontro Anual da ANPOCS, 31., 2007, Caxambu, MG. Anais... Caxambu, MG: ANPOCS, 2007.

GIUGNI, Marco G.; PASSY, Florence. Contentious politics in complex societies: new social movements between conflict and cooperation. In: GIUGNI, Marco; McADAM, Doug; TILLY, Charles (eds.). From contention to democracy. Lanham: Rowman \& Littlefield, 1998.

MALVEZZI, Roberto. Semi-árido: uma visão holística. Brasília: CONFEA, 2007. 140p. 
MINIHUBER, Klaus; BAPTISTA, Naidison. A experiência de capacitação de recursos do Movimento de Organização Comunitária (MOC): parceria com empresas e doação de recursos por pessoas físicas. In: Seminário Sustentabilidade e Mobilização de Recursos para os OSCs. Uma Visão Político-Estratégica para o Desenvolvimento do Nordeste. Recife, 2009.

MOC - MOVIMENTO DE ORGANIZAÇÃO COMUNITÁRIA. O MOC na linha do tempo: MOC 40 anos. Feira de Santana, 2007.

. Políticas públicas: intervenção na construção e acesso. Relatório Anual de Atividades 2009. Feira de Santana- BA, 2009.

A contribuição do MOC para a convivência com o Semi-árido. Relatório Anual de Atividades 2010. Feira de Santana - BA, 2010.

PAIXÃO, Clodoaldo Almeida da. A trajetória de Políticas Públicas no MOC, 2006. Disponível em: <http://www.moc.org.br/artigos/23-05-2007_16_11_59.pdf>, acesso em 21 dez. 2011.

ROSENBLUM, Nancy L.; LESCH, Charles H. T.. Civil Society and Government. In: EDWARDS, Michael (ed.). The Oxford Handbook of Civil Society. Oxford: Oxford University Press, 2011.

SCHMITT, C. et. al. Relatório de Pesquisa. Políticas em rede: uma análise comparativa das interdependências entre o Programa de Aquisição de Alimentos e as redes associativas na Bahia e no Rio Grande do Sul. Programa de Pós-Graduação de Ciências Sociais em Desenvolvimento, Agricultura e Sociedade (CPDA/UFRRJ). Financiada pela Fundação de Apoio à Pesquisa do Estado do Rio de Janeiro - FAPERJ, 2012. 



\title{
VII
}

\section{Mediação social em projetos de desenvolvimento: os ADRS e a caprinocultura leiteira no cariri paraibano}

\author{
Valdênio Meneses ${ }^{61}$ \\ Ramonildes Gomes ${ }^{62}$
}

\section{Introdução}

O debate sobre temas como - mediação social, políticas públicas e desenvolvimento amplia as possibilidades de análise e visualização de processos e agentes sociais que atuam no campo delimitado - pela articulação entre as instituições interventoras e os grupos-alvo dos projetos de intervenção. Sob diferentes perspectivas, autores como Sardan (1997), Neves (2008) e Deponti e Almeida (2008) têm refletido sobre as singularidades que os processos de mediação social adquirem em projetos que, apoiados no termo desenvolvimento, visam promover mudanças no meio rural. Destacam-se nessas reflexões a importância da formação dos mediadores e as possibilidades de ação destes nos espaços entre as instituições gestoras e os grupos sociais que são alvo dos projetos de intervenção pública.

61 Valdênio Meneses/ Mestrando pelo Programa de Pós-Graduação de Ciências Sociais (PPGCS) da Universidade Federal de Campina Grande (UFCG) - valdeniofmeneses@hotmail.com

62 Ramonildes Gomes / Professora Doutora do PPGCS-UFCG - rnildes@hotmail.com 
Tomando por base a discussão sobre a relação dos mediadores na constituição de projetos de desenvolvimento, o principal objetivo deste artigo é analisar processos de mediação estabelecidos por uma articulação de ações de intervenção para estimular a pecuária de caprinos, na região do Cariri Paraibano, tendo como público alvo os agricultores familiares. Direcionamos o foco da análise para os Agentes de Desenvolvimento Regional Sustentável (ADRS), capacitados para realizar atividades de assistência técnica e extensão rural específicas para a caprinocultura leiteira em um projeto gerido pelo SEBRAE-PB e a Fundação Banco do Brasil.

A pesquisa pautou-se na análise documental do projeto do Sebrae-PB Capacitação de agentes de desenvolvimento rural (ADRs) para a caprinovinocultura de - edições da revista de publicidade Sebrae: Agronegócios que destacam a atuação dos ADRS e as cartilhas do Plano de Desenvolvimento Rural Sustentável (DRS) da Fundação Banco do Brasil. Apoiamos ainda nossas análises em relatórios mensais de avaliação elaborados pelos ADRS e nos dados obtidos através de entrevistas semiestruturadas com agentes de desenvolvimento que atuam nos municípios de Sumé, Monteiro, Zabelê, São Sebastião do Umbuzeiro e Amparo. Outras impressões foram registradas nos momentos em que acompanhamos alguns ADRS, durante as visitas destes as propriedades dos agricultores familiares nos municípios já citados.

Algumas questões nortearam as análises e dentre estas: - Em quais referências cognitivas se apoiam os processos de mediação social que fundamentam as ações dos ADRS? Como esse agente é formado dentro dos projetos do Sebrae-PB e da Fundação Banco do Brasil para atuar na propagação de um projeto de desenvolvimento voltado para a produção do "leite de cabra" ? Que aspectos caracterizam a prática do ADRS na "difusão e tradução" de referências junto aos agricultores familiares que são alvo de ações voltadas para o "desenvolvimento"? Como o ADRS vivenciam os conflitos oriundos de diferentes representações sociais que instituições, mediadores e mediados possuem sobre a caprinocultura?

$\mathrm{O}$ artigo está estruturado em duas partes, além das considerações finais: 
1) Um recorte mais conceitual acerca dos processos de transformação social, pensados em termos de diferenciação, racionalização e elementos institucionais que influenciam na constituição dos mediadores sociais profissionalizados. Este tipo profissional de mediação social ganha conotação singular a partir de uma dimensão cognitiva de políticas públicas pautadas em torno de produção e difusão de crenças no termo desenvolvimento. A análise mais conceitual destaca que contradições de um projeto de desenvolvimento podem ser visualizadas no modo como os mediadores incorporam os conflitos performativos de distintas visões de mundo, entre os grupos sociais envolvidos;

2) Um enfoque mais centrado nos processos de mediação que envolvem os ADRS. Destacamos a base institucional do projeto ADRS e o conflito entre diferentes referenciais cognitivos que estes mediadores estão envolvidos: o embate entre a racionalidade técnica para a caprinocultura incutida pelo Sebrae-PB no curso de capacitação dos ADRS contra formas de conhecimento sobre a pecuária trazidas pelos agricultores familiares que são alvo dos projetos. Ressaltamos que certas estratégias produtivas adotadas pelos caprinocultores referenciam uma dimensão do processo de mediação levado a cabo pelos ADRS, mas que não é reconhecida no projeto encabeçado pelo Sebrae-PB. Trata-se da forma como o ADRS incorpora as distintas visões de mundo que se expressam nas práticas cotidianas com a pecuária caprina, negociando referenciais comuns aos agricultores familiares. Esta dimensão "irreconhecida" da mediação, realizada pelo ADRS está conectada a contradições do projeto de desenvolvimento que os capacitou para serem mediadores.

\section{Mediação social, racionalização e padrões institucionais}

Qualificamos os ADRS como mediadores sociais a partir de dois eixos teóricos. O primeiro, mais geral, que trata da formação de mediadores sociais associados a processos de racionalização e diferenciação que caracterizam as instituições modernas. O segundo, mais específico, que considera a mediação social sob um viés 
cognitivo, no qual a crença na proposta do desenvolvimento é a marca das políticas públicas.

A definição de mediador social que norteia este trabalho considera a profissionalização institucional de agentes sociais como condição para o exercício da mediação. Neves (2008) distingue dois padrões de mediadores sociais, os que vivem pela mediação e os que vivem da mediação. Nos primeiros, podem ser incluídos políticos, professores, padres que agem segundo o prestígio que exercem nos grupos e comunidades das quais fazem parte. Já os segundos possuem competências específicas para mediar algo, sendo "alocados para dar existência às representações delegadas e à administração e intervenção públicas” (NEVES, 2008, p.28). Estes são os mediadores profissionais para os quais direcionamos alguns apontamentos.

A constituição dessa competência profissional de um mediador está associada a processos inerentes à gênese da sociedade moderna, esta formada a partir de descontinuidades em relação aos padrões tradicionais (GIDDENS, 1991). Nestas rupturas que caracterizam a modernidade, destacam-se as conexões entre processos de diferenciação e a racionalização e mudança institucional.

Sobre a diferenciação de elementos que compõem a vida social, Durkheim (2010) enfatiza que a divisão social do trabalho está relacionada com a transformação de formas de coesão e organização social, que passam a ser cada vez mais baseadas na separação e especialização de segmentos. Para Max Weber, estas dinâmicas que tornam heterogêneos elementos da vida social são parte de um processo maior de racionalização, a partir de sua forma específica no ocidente. A racionalidade ocidental, segundo Weber (2004), é o resultado de uma combinação de variáveis, sendo privilegiada em uma de suas principais análises a afinidade eletiva entre um sistema de valores do modo de produção capitalista e referências de ação de segmentos protestantes. Um aspecto chave da racionalização é a gênese de espaços diferenciados regidos por um modus operandi específico, a exemplo da burocracia e o funcionamento do Estado moderno: trata-se de um corpo de posições ocupadas 
por funcionários especializados em uma linguagem e domínios congruentes regidos pela constituição impessoal de leis, regras e normas administrativas (WEBER, 1982). Tais "mundos" dinamizados por lógicas específicas são revestidos conceitualmente de forma mais precisa a partir da noção de campo de Pierre Bourdieu: "sistemas de relações objetivas entre posições ocupadas por agentes que se encontram em disputa de poder dentro de microcosmos sociais dotados de propriedades específicas (BOURDIEU, 2009, p.67).

Diferenciação e racionalização compõem padrões que dão às instituições sociais modernas um caráter específico. Giddens (1991) aponta que na ascensão das instituições modernas há uma natureza intrínseca distinta de todos os tipos da ordem tradicional na transformação das relações sociais através da redefinição de padrões espaciais e temporais: movimentações estabelecidas pelo "desencaixe de relações sociais de contexto local de interação e sua reestruturação através de extensões indefinidas de espaço e tempo" (GIDDENS,1991, p.21). A consagração do mediador social, em primeira instância, é um processo gerido por instituições qualificadas nesses padrões modernos. O caráter institucional moderno que Giddens (1991) destaca está diretamente relacionado à natureza dos processos que envolvem os mediadores profissionais.

Esta relação entre o padrão institucional moderno e mediação social ganha contornos específicos, segundo a condição em que instituições gestoras de políticas públicas estejam apoiadas em crença no desenvolvimento e busquem impor seus projetos através de formas de contato, via mediadores sociais, aos grupos sociais que são alvo das intervenções. Para analisar os elos que sustentam o "tripé" instituições, mediadores e mediados, destacamos a dimensão cognitiva das políticas públicas.

\section{Desenvolvimento, mediação social e dimensão cognitiva de políticas publicas}

O termo "desenvolvimento" faz parte de um conjunto de princípios normativos de uso recorrente no debate sobre políticas públicas, mas que não possuem uma única definição, 
apresentando-se sob uma variedade de significados (NEVES, 2008). Tratamos a relação desenvolvimento, mediação social e políticas públicas enfatizando processos sociais a partir de interdependências estabelecidas, entre indivíduos e grupos (ELIAS, 1994); e em uma dimensão cognitiva, na qual a política pública é percebida não apenas como "resolução de problemas", mas também como intercâmbio de formas de representação social e construção de quadros de interpretação do mundo (MULLER, 2000, p.194).

Afastando-nos de uma proposta metodológica orientada por uma lógica normativa, acentuamos o fator da produção de crenças $^{63}$ a partir das interdependências estabelecidas em uma "configuração desenvolvimentista" - um universo de experts, burocratas, representantes de ONGs, pesquisadores, técnicos que mobiliza e gerencia recursos materiais e simbólicos em nome de uma proposta de desenvolvimento para outros grupos sociais (SARDAN, 1995). Nesse tipo de configuração, há aqueles agentes que são delegados para posições de contato e negociação junto aos segmentos sociais que são alvo da intervenção. "Há uma rede de relações que conferem ao mediador tal status" (DEPONTI; ALMEIDA, 2008, p.3).

Segundo Sardan (1995), os processos de mediação relativos a projetos de desenvolvimento são marcados recorrentemente por contradições que envolvem simbolicamente o mediador em imagem de mensageiro de inovações apoiadas pelo discurso técnico-científico, mas também como espécie de atravessador (courtage) que elabora negociações e trocas entre diferentes tipos de conhecimento elaborados e circulados na arena das instituições desenvolvimentistas e na arena local dos grupos-alvo. A contradição é firmada na medida em que as instituições que gerenciam o projeto de desenvolvimento reconhecem unicamente uma característica da ação do mediador, qual seja a de porta-voz do 'saber

63 A legitimação de uma crença está ligada à consagração de um sistema de representação social, sendo um crédito produzido junto a um conjunto de agentes e instituições que dentro de um campo de produção constituem um sistema de relações objetivas e um espaço de lutas pelo monopólio do poder de consagração (BOURDIEU, 2004, p. 25). 
técnico-científico' (SARDAN, 1995, p.156). É negada a existência de uma dimensão conflituosa no interior do projeto de desenvolvimento, esta que é vivenciada diretamente pelo próprio mediador no curso da ação.

Os agentes de desenvolvimento são estimulados pelo conjunto das instituições gestoras a empreender uma operação de desqualificação e não de comunicação com o savoir-faire dos mediados (SARDAN, 1995). O próprio mediador exalta o conjunto de instituições que o consagrou profissionalmente, ele se autonomeia porta-voz do conhecimento técnico-científico, muitas vezes até como um salvador/emancipador dos grupos que são alvo da política pública, que são vistos como detentores de um saber insuficiente sendo agentes passivos que necessitam de uma intervenção externa que os capacite para uma mudança benéfica (SARDAN, 1995, p.156).

A "irreconhecida" dimensão comunicativa da mediação social pressupõe que a mediação social pode conter - além de imposições de um padrão cognitivo - possibilidades de trânsito de lógicas de conhecimentos diferentes, sendo o mediador não apenas um mensageiro de inovações mas também um negociador que busca construir consensos diante do conflito entre diferentes representações e práticas sociais. O reconhecimento desta dimensão dialógica que atravessa o cotidiano do mediador significa uma abertura para que o conjunto de crenças dos mediados também influencie nas práticas do mediador e até mesmo no projeto de desenvolvimento. Os processos de mediação por esse aspecto privilegiam uma via "pedagógica destinada a mudar comportamentos e visões de mundo" (NEVES, 2005, p.190).

\section{Projeto ADRS: Constituição de um mediador social no contexto da caprinocultura leiteira no cariri paraibano}

A capacitação profissional do ADRS se insere na produção simbólica de um ideário de desenvolvimento voltado para a caprinocultura leiteira no Cariri Paraibano. A assistência técnica e extensão feitas pelos ADRS aos caprinocultores têm o objetivo de difundir o conhecimento técnico e uma lógica empreendedora 
defendidas pelo Sebrae-PB e da Fundação Banco do Brasil. Esta "missão" conferida aos ADRS está investida de informações e permeada por conflitos e tensões inerentes ao exercício da mediação social, expressando as contradições do próprio projeto que capacitou os mediadores.

A formulação de uma lógica de desenvolvimento e as articulações que conferem sustentação institucional ao projeto ADRS têm origem no Pacto Novo Cariri. Desde o final da década de 1990, a partir de acordos entre prefeituras, empresas e associações civis, o desenvolvimento tem sido priorizado a partir da ativação do que seria uma "potencialidade natural" do Cariri paraibano para a caprinocultura leiteira (SEBRAE, 2003). O conjunto dessas alianças entre a sociedade civil, a livre iniciativa e as entidades públicas compõe o chamado Pacto Novo Cariri, o qual define como objetivo: «Desenvolver o Cariri Paraibano através da gestão compartilhada dos projetos e atividades no qual a caprinocultura e a ovinocultura foram consideradas como principais prioridades". (SEBRAE, 2003, p.8).

Para alcançar esse objetivo, foram mobilizadas gradativamente $^{64}$ algumas instituições e programas: Sebrae-PB, Fundação Banco do Brasil ; Projeto Dom Hélder Câmara ; PRONAF e Programa de Aquisição de Alimentos (PAA)/Leite e uma rede de associações; cooperativas de caprinocultores e as usinas de beneficiamento do leite de cabra. Sob este tecido institucional que se definiu um modelo de ação para os ADRS que teve origem no projeto Agente de Desenvolvimento Rural (ADR) do Sebrae-PB, que surgiu em 2003. A partir de medidas como a importação de raças leiteiras de outros estados do Brasil e a adoção de novas formas de organização produtiva, o projeto ADR propunha uma assistência técnica baseada no seguinte princípio: «A reformulação dos modelos tradicionais

64 No artigo, "As políticas públicas de incentivo a '(re)pecuarização' no semiárido nordestino': desenvolvimento, modernização e recomposição espacial, Gomes e Meneses (2010) detalham o processo de formação desta articulação de políticas públicas e programas governamentais sobre a caprinocultura no Cariri Paraibano. 
de planejamento e gestão, a fim de ajustar a visão de suas possibilidades e perspectivas de desenvolvimento" (SEBRAE, 2003, p.10).

Entre os principais objetivos do Projeto ADR, destaca-se a criação de oportunidades para entrada no mercado de trabalho de jovens técnicos-extensionistas; ao mesmo tempo, a formação de agentes para difundir os pacotes, cujo objetivo era fortalecer as ideias de empreendedorismo via caprinocultura do SEBRAE. Os critérios adotados para seleção dos técnicos consistiam em que estes fossem recrutados nos municípios nos quais iriam desenvolver as ações, com o argumento de que o pertencimento ao local facilitaria o compartilhamento de conhecimentos técnicos sobre a criação de caprinos (SEBRAE, 2003, p. 20). Em 2006, após uma crise financeira e administrativa, o nome do projeto ADR muda para ADRS. Neste momento, a Fundação Banco do Brasil integra a parceria do Projeto e insere um plano de negócios de Desenvolvimento Regional Sustentável (DRS) que, semelhante ao Pacto Novo Cariri, elege a caprinocultura como estratégia produtiva para ativar potencialidades locais no Cariri paraibano. Todavia, agora com argumento de que seria necessário fortalecer o chamado negócio sustentável (FUNDAÇÃO BANCO DO BRASIL/IICA, 2008). Nos idos de 2007, um conjunto de cooperativas (COOAGRIL) também passa a fazer parte da gestão do Projeto ADRS.

Estas mudanças na gestão institucional pelas quais o projeto ADR passou se traduzem em alterações na proposta inicial, a exemplo do processo de seleção dos técnicos para compor o quadro de extensionistas. Se inicialmente o objetivo era contratar jovenstécnicos sem nenhuma experiência profissional, os dados obtidos, quando da aplicação dos questionários revelaram que, atualmente, muitos dos técnicos selecionados já possuíam experiência profissional com assistência técnica. No quadro abaixo, apresentamos uma caracterização geral dos seis ADRS com os quais aprofundamos a pesquisa e que atuam nos seguintes municípios: Monteiro, Sumé, São Sebastião do Umbuzeiro, Amparo e Zabelê. 
PERFIL GERAL DOS ADRS

\begin{tabular}{|l|l|l|l|l|}
\hline Cidade & Idade & $\begin{array}{c}\text { Formação } \\
\text { Escolar }\end{array}$ & $\begin{array}{c}\text { Vínculos } \\
\text { Institucionais }\end{array}$ & $\begin{array}{c}\text { Experiências } \\
\text { Anteriores com ativi- } \\
\text { dade agropecuária }\end{array}$ \\
\hline Amparo & 30 anos & $\begin{array}{l}\text { Técnico } \\
\text { (agropecuária) }\end{array}$ & $\begin{array}{l}\text { BB, COOAGRIL } \\
\text { SEBRAE, CAA }\end{array}$ & É filho de produtor \\
\hline Monteiro & 47 anos & Ensino médio & $\begin{array}{l}\text { BB,COOAGRIL, } \\
\text { SEBRAE, } \\
\text { CAPRIBOM }\end{array}$ & $\begin{array}{l}\text { Trabalhou com } \\
\text { assistência técnica } \\
\text { para agricultura na } \\
\text { fundação BB. }\end{array}$ \\
\hline Monteiro & 37 anos & Ensino médio & $\begin{array}{l}\text { BB,COOAGRIL, } \\
\text { SEBRAE, } \\
\text { CAPRIBOM }\end{array}$ & $\begin{array}{l}\text { Trabalhou com } \\
\text { assistência técnica na } \\
\text { pecuária bovina }\end{array}$ \\
\hline $\begin{array}{l}\text { S.S. do } \\
\text { Umbuzeiro }\end{array}$ & 19 anos & $\begin{array}{l}\text { Técnico } \\
\text { (agropecuária) }\end{array}$ & $\begin{array}{l}\text { BB; COOAGRIL; } \\
\text { SEBRAE, Laticínio } \\
\text { Vila Caroá }\end{array}$ & $\begin{array}{l}\text { Primeira experiência } \\
\text { profissional dentro do } \\
\text { projeto do ADRS }\end{array}$ \\
\hline Sumé & 24 anos & $\begin{array}{l}\text { Técnico } \\
\text { (agropecuária) }\end{array}$ & $\begin{array}{l}\text { BB, COOAGRIL, } \\
\text { SEBRAE, EMATER }\end{array}$ & $\begin{array}{l}\text { Primeira experiência } \\
\text { profissional dentro do } \\
\text { projeto ADRS }\end{array}$ \\
\hline Zabelê & 29 anos & $\begin{array}{l}\text { Técnico } \\
\text { (agropecuária) }\end{array}$ & $\begin{array}{l}\text { BB,COOAGRIL, } \\
\text { SEBRAE, ACCOZA }\end{array}$ & $\begin{array}{l}\text { Trabalhou com STRs, } \\
\text { CUT e EMATER. }\end{array}$ \\
\hline
\end{tabular}

QUADRO 5 - Perfil geral dos ADRS

FONTE - Valdênio Meneses

Atualmente constata-se que não há mais critérios para o recrutamento dos novos ADRS, prevalecendo a indicação feita pelas associações municipais de caprinocultores. São recrutados de 1 a 3 ADRS por município. A capacitação inicial, difundida como formação, consiste em aulas teóricas e de campo ministradas em um período de 10 a 15 dias, na sede do Centro de Desenvolvimento da Caprinovinocultura (CENDOV) no município de Monteiro. De acordo com porta-vozes do Sebrae (2003), depois que o ADRS assume o cargo, ele passa, mensalmente, por oficinas e cursos para receber informações sobre as experiências de extensão e "reciclagem" de conhecimentos.

A distribuição dos ADRS para prestação da assistência técnica é de um para quinze agricultores, em geral residentes na mesma comunidade. Para que os técnicos visitem as propriedades, os agricultores são previamente cadastrados no projeto ADRS, através 
das associações de caprinocultore ${ }^{65}$ Quanto à questão de contrato trabalhista, o vínculo formal dos ADRS é regido por um contrato de trabalho que tem a duração de 1 ano, podendo ser renovado ao final. A remuneração percebida pelos agentes é de pouco mais de um salário mínimo (cerca de $\mathrm{R} \$ 700,00$ ), além disso, as usinas de beneficiamento do leite de cabra repassam um valor, denominado de comissão com objetivo de ajudar no combustível para assegurar o transporte que os ADRS utilizam para visitar as propriedades.

Toda essa configuração de instituições, recursos e normas que sustenta o projeto ADRS tem sua eficácia simbólica produzida mediante aquilo que Sardan (1995) destaca do mediador: «que é reconhecido e se reconhece como porta-voz de uma 'linguagemdesenvolvimento' " ! (SARDAN, 1995, p.156). O ADRS é depositário de um saber técnico-científico que será operacionalizado, por vezes de maneira impositiva. Na situação experienciada pelos ADRS, a performance do extensionista baseia-se em modelo de conhecimento legitimado por uma racionalidade técnico-científica para a criação de caprinos. O "saber técnico" que o ADRS domina se traduz nos seguintes princípios:

1) Seleção de raças de animais e práticas produtivas: o ADRS caracteriza as heterogeneidades de um rebanho para uma seleção dos melhores animais, segundo a capacidade produtiva (para o leite) e reprodutiva. Com dispositivos e técnicas de identificação dos animais (como uso de brincos), são registradas informações do tipo, nascimento, idade, peso e lactação das fêmeas. Os dados são arquivados em fichas cadastrais que são utilizados como referências pelo ADRS para fazer uma série de sugestões ao produtor: formas de criação intensiva ou semi-intensiva, adoção de raças exógenas com melhor potencial leiteiro (como a Saanen ou Toggemburg), assepsia das tetas no momento da ordenha das cabras, controle hormonal, vacinação, separação das cabras em lactação do resto do rebanho e descarte daqueles que estão doentes ou velhos;

65 O associativismo é uma "bandeira" defendida de forma intensa pelo SEBRAE e outras instituições que estimulam a caprinocultura no Cariri Paraibano. A associação é vista como forma do agricultor familiar "superar debilidades peculiares dispor de poder político para levar suas reivindicações” (SEBRAE, 2003, p.7). 
2) Construção de instalações na propriedade: dominar essa informação é fundamental para facilitar as práticas de controle sanitário e nutrição, além de tornar a caprinocultura viável economicamente e, ao longo prazo, condições que requerem a construção de um curral de alvenaria para o manejo, sala de ordenha para um controle mais rígido da separação das cabras em gestação e lactação, além de atender às exigências fitossanitárias para a qualidade do leite. O ADRS auxilia também na elaboração de projeto para acesso ao crédito, junto ao BNB ou Banco do Brasil, para viabilizar a construção das futuras instalações;

3) Nutrição animal: inserção de espécies forrageiras de capim sorgo, capim elefante, capim buffel, palma - em substituição do uso de pastagem natural para alimentar o rebanho. $O$ fator nutricional tem importância fundamental para a definição da caprinocultura, como estratégia produtiva eficiente e capaz de satisfazer as exigências dos programas governamentais de distribuição de alimentos.

Dominar esse repertório é fundamental para o ADRS e, com base nesses conhecimentos, ele constrói os relatórios mensais de avaliação que são entregues ao Sebrae-PB, associações e cooperativas de caprinocultores.

A legitimação de um padrão desenvolvimentista ocorre por intermédio de processos de mediação, tendo como estratégia "a desqualificação de certos saberes e modos de participação" (NEVES, 2005, p.190). A experiência dos ADRS para o desenvolvimento da caprinocultura é exemplar dessa estratégia de desqualificação, na medida em que o savoir-faire dos caprinocultores é desconsiderado pelos técnicos mediadores. A mensagem técnica, difundida pelo mediador, inibe e neutraliza a do seu receptor. Na narrativa encontrada em uma das revistas do SEBRAE, verifica-se que, na medida em que caprinocultor é assistido pelos ADRS, ele é visto como um ser vazio de informações e cultura; já o técnico é um salvador, portador da luz e de todo o conhecimento que irá conduzi-lo ao paraíso.

O caprinocultor paraibano Cícero dos Santos demorou a entender. Afinal, por que lavavam as tetas das cabras e separá-las dos machos 
antes de começar a ordenha? Agora, ele não apenas sabe a importância dessas técnicas para evitar odores desagradáveis no leite, como as ensina a outros produtores da mesma comunidade. "É importante higienizar as tetas para garantir a qualidade do leite e separar o macho porque o cheiro dele também pega no produto", explica. (REVISTA SEBRAE AGRONEGÓCIOS, 2006, p. 13)

A imagem do "salvador" que é portador de um conhecimento "iluminado" também corresponde à representação que os mediadores têm de si mesmos. Nas entrevistas feitas com os agentes, ficam evidentes os atributos, a partir dos quais os ADRS se pensam nesse contexto como orientadores, aqueles que conduzem as mudanças:

Valdênio: Qual a função principal do ADRS?

ADRS-Sumé: É (...) orientar o produtor na higiene do leite, higiene das instalações, o manejo animal, tudo que for da área de caprino e ovino, higiene (...). Orientar eles a ter mais cuidado no suporte forrageiro, não depender só da ração.

Além de "salvador", o ADRS também se apresenta como um expert na arte de convencer. O trabalho de persuasão é destacado pelos ADRS através do "ver para crer", uma estratégia quase "mágica" para incutir junto ao caprinocultor um habitus empreendedor. Assim, quando perguntamos sobre como se dava a participação dos caprinocultores nas atividades de extensão, o ADRS que trabalha no município de São Sebastião do Umbuzeiro, relata: "ADRS-São Sebastião do Umbuzeiro: (...) no início havia resistência porque os caprinocultores viam as cabras doentes e diziam não servem, não prestam (...) mas quando começou a ver que dá resultados aderiu ao projeto".

Por outro lado, há um "irreconhecimento" principalmente do Sebrae-PB de que lógicas de ação e lógicas de conhecimento sobre a caprinocultura entram em conflito, dialogam e se confundem na missão dos ADRS, enquanto mediadores. Retomando agora a 
análise que Sardan (1995) faz do modo como se planeja a intervenção pública em regiões com pouco ou nenhum dinamismo, em que os agentes da mediação são profissionais de um mercado cujo objetivo é produzir crenças e moldar condutas, a tendência é que esta produção não se faça sem enfrentamentos. Os mediadores, em contato com os mediados, são permanentemente confrontados com situações, fenômenos sociais e racionalidades aos quais não foram preparados para enfrentar no processo de capacitação das instituições desenvolvimentistas. A propagada passividade dos beneficiários nos discursos das instituições desenvolvimentista é uma falsa impressão:

Mesmo aceitando o engajamento em processos de mudanças intencionais, os reivindicados beneficiários não podem ser pensados sob a metáfora da esponja de água. Eles tentam reordenar os objetivos reconhecidos conforme seus interesses e saberes mais imediatos. Integram-se para tornar suas expectativas, valores e pontos de vista factíveis e objetiváveis, para além de tornar seus os objetivos apresentados no contexto dos processos de mudanças (NEVES, 2008, p.36)

$\mathrm{Na}$ tentativa de melhor apreender a lógica dos mediados e o modo como estes negociam e combinam os interesses das agências, dos mediadores, nessa situação particular dos ADRS, e os seus próprios como caprinocultores, procuramos refletir sobre as narrativas de alguns caprinocultores no município de Sumé, com intuito de perceber como eles mesmos lidam com diferentes racionalidades e se opõem ao modelo esponja de água:

O caprinocultor $1^{2}$ cria cabras desde o ano 2000, quando começou a participar de pequenos programas de estímulo à caprinocultura leiteira que depois se unem ao PAA/Leite. Este senhor reside com sua esposa em uma propriedade na localidade "Pitombeira", às margens do açude de Sumé - possuindo uma fonte hídrica perene e abundante. Em sua propriedade, existe atualmente sala de ordenha 
de alvenaria; três currais, um onde é feita a nutrição dos animais outro curral gradeado, destinado a separar os animais em processo de lactação, outro curral para os filhotes, além de áreas cultivadas com vegetação para suporte forrageiro - capim buffel e palma. Utiliza-se de práticas extensivas e intensivas para alimentar os animais. O caprinocultor relata que adquiriu animais de raças próprias para produção de leite, através de um projeto financiado pelo Sebrae-PB e pelo Projeto Dom Hélder Câmara.

A explicação para as transformações ocorridas no espaço da propriedade e nas práticas de criação visavam ao melhoramento da produção leiteira, para que o produto fosse aceito pela usina. Os avanços na produção do leite de cabra se deram principalmente a partir da construção de uma sala de ordenha afastada do curral - construída com recursos obtidos por crédito PRONAF(B) - e a limpeza das tetas das cabras utilizando toalhas descartáveis. Apesar de investir nas inovações do espaço da propriedade e no rebanho o caprinocultor 1 não utiliza da pecuária caprina apenas visando a melhoramentos técnicos para a produção de leite. No ano anterior, o produtor vendeu algumas "cabras de raça" e, segundo ele, o dinheiro obtido com essa venda foi utilizado para pagar parte do PRONAF, mas também foi utilizado para ajudar os filhos que moram em outra cidade:

Caprinocultor 1: (...) A gente tem os meninos que moram de aluguel né? Os meninos que estudam moram de aluguel (...) uma menina e um menino. 0 menino trabalha (...) ele ensina no colégio, dá aula de português no colégio e a tarde vai pra universidade daqui do campus de Sumé e à noite para Monteiro (grifo do autor).

Por sua vez, o caprinocultor 2 relata que mora com a esposa e dois filhos na localidade de Terra Vermelha, ${ }^{3}$ uma área de antigos lotes do DNOCS. O produtor afirma que conheceu a caprinocultura, quando ainda era menino, uma vez que seus pais já praticavam a atividade em outra localidade na zona rural do município de Sumé. Quando retorna de São Paulo em 2006, o caprinocultor é estimulado 
pelo irmão a criar cabras leiteiras e entrar na associação de Terra Vermelha, quando passa a ser assistido pelos ADRS. O caprinocultor 2 adquire as primeiras cabras leiteiras da raça Saanen vindas de Minas Gerais, dentro de uma parceria do Sebrae-PB, Fundação Banco do Brasil e no escritório local da EMATER em Sumé. Na propriedade, não há sala de ordenha, mas há uma "rampa" improvisada para separar as cabras do rebanho e retirar o leite. Estimulado pelos ADRS para criar cabras na sua propriedade, o caprinocultor 2 foi orientado para desenvolver uma estratégia produtiva intensiva de confinamento dos animais. Contudo, ele faz críticas a forma como as cabras foram "importadas" pelo Sebrae e Banco do Brasil, pois alega que as cabras não eram adaptadas à região do Cariri. Algumas cabras ficaram doentes e vieram a falecer, o que fez com que ele deixasse de seguir todas as orientações técnicas, utilizando práticas extensivas para alimentar os animais.

Caprinocultor 2: "Deixar apenas os animais trancado não deu certo. Por isso decidi alimentar elas soltando uma parte da manhã e alternar com a ração dada no cocho, para não perder por completo, né? (...) as matrizes não se adaptaram bem (...) eram umas cabras criadas em estábulo (...) nesses negócios todos o clima era outro". (Caprinocultor 2, grifo do autor).

Já o caprinocultor 3 mora com um irmão nas proximidades da usina de leite que fica no Condomínio Agroindustrial (CAA) em Amparo, o que permite que ele mesmo deixe o leite de cabra, na usina, utilizando sua motocicleta, sem necessidade de pagar a um atravessador. 0 caprinocultor 3 divide com o irmão um rebanho de 60 caprinos, sendo que 18 são cabras leiteiras. Ele elogia o Programa do Leite (no qual é cadastrado desde 2005) por considerar uma forma "segura" para vender o leite de cabra. Afirma que antes criava caprinos apenas para "venda" e abate, mas com o estímulo do irmão e da associação do Condomínio resolveu criar cabras leiteiras. O acordo com o irmão é explicado da seguinte forma: 
Caprinocultor 3: "Meu irmão tem uma casa dele mas como a gente trabalha junto fica muito tempo na mesma casa (...) a gente recebe pelo banco (...) tem os cartão e as conta de cada um (...) divide os gastos com ração (...) isso auxiliou em problemas na capacidade pra vender o leite" (Caprinocultor 3, grifo do autor - informação verbal).

Essa "parceria" também propicia uma espécie de "rodízio" de animais quando algumas fêmeas estiverem em fase inicial de lactação, momento em que a produção de leite fica limitada. Segundo o caprinocultor 3, produzir em 'consórcio' com o irmão também ajudou a resolver um problema de 'tempo' além dos cuidados na ordenha e no plantio de suporte forrageiro (soja e palma) para nutrição dos animais.

Os três casos relatados são exemplares de como são elaboradas estratégias guiadas por racionalidades diferentes, para os caprinocultores justificarem tanto a adesão ao padrão técnico, como a combinação de outros fatores, principalmente através de relações familiares. Notamos que o caprinocultor 1 adere imediatamente ao projeto de desenvolvimento propagado pelo ADRS, a partir da incorporação da lógica difundida pelos técnicos, mas não referencia a criação de caprinos apenas como atividade econômica estrita de investimento e lucro, já que "guarda" animais para vender e suprir necessidades de seus filhos. Por outro lado, o caprinocultor 2 organiza suas estratégias para a caprinocultura, aderindo a um projeto que traz inovações ao mesmo tempo em que faz críticas a implementação da parceria que trouxe cabras de raças leiteiras para o Cariri. Quando explica sua estratégia ante o problema das cabras "mineiras", ele utiliza argumentos de que envolvem saberes ligados a uma incorporação do discurso técnico-científico junto a formas de criação de caprinos que aprendeu com os pais. A pecuária também é uma via importante de trocas dentro do grupo familiar no caso do caprinocultor 3 que compartilha em uma relação de confiança com o irmão todo o rebanho e as decisões quanto 
ao melhoramento da produção leiteira. Além disso, há uma possível tática de juntar a produção leiteira com o irmão para tentar vender uma quantidade de litros de leite para além das cotas-limite 4 instituídas pelas usinas e pelo PAA/Leite.

Em um plano geral, podemos perceber que, em situações de transformação de valores e formas de conduta através da inserção de inovações técnicas, a "família não deixa de referenciar práticas e representações" (WANDERLEY, 2001, p.51). A inserção de novos referenciais para a caprinocultura através dos ADRS não significa a eliminação de racionalidades e estratégias que entrelaçam um saber herdado, geralmente incorporado através da família.

Essas bricolagens de conhecimentos e lógicas produtivas feitas pelos caprinocultores incidem diretamente em processos de mediação dos ADRS. Para além de ser unicamente (trans)portador de uma racionalidade técnica, o ADRS acaba por ser um agente social que se coloca em um front de conflitos e situações entrecortadas por cruzamentos de significados que contradizem com a proposta desenvolvimentista ao qual o mediador foi capacitado. Mesmo que o ADRS assuma a condição de porta-voz de um saber técnico-científico e rejeite qualquer outro tipo de conhecimento que não seja aquele defendido pela instituição que o capacitou, no exercício cotidiano de sua atividade profissional, ele se depara com as diferenças e a necessidade de criar zonas de intercâmbio entre formas de representação social sobre a caprinocultura. Incorporando as diferenças, o mediador social busca negociar um consenso para que a proposta de desenvolvimento para a qual foi mobilizado tenha alguma efetividade.

Os vínculos que aportam a relação entre mediador e mediado são construídos em uma temporalidade e delimitado no exercício da mediação, que se organiza pela dominação via imposição de conhecimentos, "ao mesmo tempo em que é vetor de uma relação de trocas sociais" (ROS, 2008, p.99). 
As visitas periódicas feitas aos caprinocultores e o fato de os ADRS residirem, nos municípios em que efetivam suas ações, favorecem a constituição de um laço de confiança ${ }^{5}$ entre o agricultor familiar e o ADRS, ampliando as oportunidades para difusão de novos conhecimentos em um processo de comunicação constante. Os agentes constaram que quando o produtor inicia na atividade com caprinos, estes procuram conciliar inovações técnicas com os conhecimentos do senso prático. Para os ADRS, a combinação de saberes pode ser identificada nos primeiros contatos com os caprinocultores recém-egressos no projeto do Sebrae-PB em que são feitas sugestões que apontam para a complementaridade entre práticas intensivas e extensivas para criação dos animais, e também na combinação de espécies forrageiras exógenas e pastagem natural para alimentação dos caprinos. Os ADRS assinalam que há um segundo momento no curso da mediação destinada a estimular a caprinocultura, aquele que é chamado de "quebrar a resistência", em que a associação de saberes perpassa uma rotina de trabalho, que envolve a participação do mediador nas reuniões e cursos promovidos nas associações de caprinocultores. Este também é o momento em que os agricultores familiares passam a receber as primeiras visitas e o ADRS passa a registrar, no relatório mensal, as informações sobre o rebanho e a produção leiteira. Mais do que "quebrar a resistência do produtor", convencendo-o a aderir ao projeto produtivo da criação de caprinos, o ADRS busca negociar uma abertura comunicativa entre distintas lógicas simbólicas, práticas sociais e visões de mundo.

A principal evidência destas formas de contato entre os ADRS e os caprinocultores evidencia-se a partir de formas de classificação originárias do contato entre aquilo que Sardan (1995) classifica como "linguagem desenvolvimento" e "linguagem local". Este vínculo se expressa através de formas de classificação social da assistência técnica dos mediados. O termo "ajuda" usado por alguns caprinocultores para falar da assistência técnica prestada pelos ADRS, mais do que um simples recurso gramatical ou linguístico, é uma operação que se inscreve em categorias que definem um poder simbólico "por onde se atualizam relações de 
força entre os locutores e seus respectivos grupos" (BOURDIEU, 2008, p.25). Expressões do tipo "esses meninos que nos dão uma ajuda" - evidencia uma diferenciação importante em relação a técnicos extensionistas de outras instituições. Sob o ponto de vista dos mediados, aí se reveste uma atividade profissional de difusão de padrões técnicos em relações de troca e expectativas, pautadas em uma confiança que o caprinocultor tem com os ADRS. Estes se diferenciam, por exemplo, dos técnicos da EMATER, com os quais as relações por vezes são estritamente burocráticas. É nesta produção específica ao ADRS que se constituem vínculos baseados em um círculo de "proximidades", que são canais para incorporação de novas lógicas e racionalidades e, principalmente, a permanência de agricultores familiares ao projeto da caprinocultura que os ADRS buscam efetivar.

\section{Considerações Finais}

A experiência de mediação social envolvendo ADRS, caprinocultores e ações de intervenção pública, todas voltadas para o desenvolvimento da caprinocultura no Cariri paraibano, enfatiza as contradições que instigam à análise de processos caracterizados por polos distintos, pensados como positivo e negativo, simplificados na troca de saberes e visões de mundo diferentes. A partir do caso dos ADRS, buscamos compreender os mecanismos adotados pelas instituições interventoras na produção da figura do mediador social, subvertendo a ação deste aos interesses de planos, programas e projetos que ancorados no sonho do desenvolvimento subvertem também as possibilidades de diálogo, emancipação e mudança social.

A contradição mais evidente nesse processo evidencia-se no "irreconhecido" fator comunicativo que é produzido no próprio processo de mediação em que se insere a caprinocultura e a interação entre o ADRS e os mediados. Há um vínculo que envolve a difusão de inovações técnicas e relações de confiança entre diferentes agentes sociais que mesmo não planejado, nem reconhecido 
pelo Sebrae-PB, é o que propicia à adesão dos mediados à caprinocultura leiteira. $\mathrm{O}$ fato de pequenos produtores aderirem a uma proposta, com padrões e estratégias de produção modernas não ocorre automaticamente: apreender e usar o conhecimento técnico-científico passa, fundamentalmente pela incorporação de novos referenciais via estabelecimento de uma relação temporal construída entre os ADRS, propagadores de uma proposta institucional e os mediados, portadores de um universo cognitivo e simbólico específicos para classificar a pecuária caprina.

Desde o princípio, o objetivo do projeto ADRS estava voltado para a formação de jovens técnico-extensionistas que além da assistência técnica para pecuária também fossem portadores de experiências e vivências comuns com os caprinocultores cadastrados. Este requisto facilita a criação de vínculos de confiança importante para a difusão de conhecimentos inovadores, porém não há iniciativas direcionadas para reprodução de relações estabelecidas entre mediadores e mediados. A ameaça a essas relações se revela nas oscilações institucionais por que passa o projeto ADRS junto à precariedade dos contratos de trabalho, aos quais os ADRS estão submetidos. Trabalhar submetido a contratos precários dificulta a regularidade na transmissão das informações e das técnicas produtivas.

Uma conclusão que é possível apresentar está relacionada ao discurso, quase hegemônico, de que a caprinocultura tem um potencial "natural" para desenvolver e imprimir dinamismo econômico ao Cariri paraibano, bastando ao Estado e as instituições comprometidas com a intervenção investir na difusão de informações, de maneira "mágica" novos padrões produtivos seriam estabelecidos. A análise que aqui fizemos permite afirmar que se existe adesão à caprinocultura leiteira por parte de agricultores familiares, ela se faz dentro de um campo social atravessado por conflitos e consensos. 


\section{NOTAS}

- Siglas: Cooperativa dos Produtores Rurais de Monteiro (CAPRIBOM); Condomínio Agroindustrial de Amparo (CAA); Associação de Caprinovinocultores de Zabelê (ACCOZA).

- Esse primeiro exemplo foi retirado do artigo de Gamboa e Cunha (2011) que trata das transformações de estratégias produtivas de caprinocultores através dos incentivos públicos no Cariri.

- Os dados desse produtor foram obtidos a partir da aplicação de questionários com uma amostra de 27 famílias na localidade de Terra Vermelha.

- Um exemplo desse laço de confiança pode ser visto quando o produtor fornece dados pessoais (número de identidade e CPF) ao ADRS para que ele vá a cidade e prepare a documentação prévia para alguma operação de crédito. Até mesmo na experiência de pesquisa, esse laço de confiança foi visto, quando o ADRS apresentava o pesquisador aos produtores e também intermediava o diálogo. 


\section{Referências}

BOURDIEU, P. A economia das trocas linguísticas: o que falar o que dizer. 2.ed. São Paulo: Editora da Universidade de São Paulo, 2008.

A produção da crença: contribuição para uma economia dos bens simbólicos. São Paulo: Zouk, 2004.

. O senso prático. Petrópolis: Vozes, 2009.

DEPONTI, C. M; ALMEIDA, J. Sobre o processo de mediação nos projetos de desenvolvimento: uma reflexão teórica. XLVI Congresso da Sociedade Brasileira de Economia - Administração e Sociologia Rural (SOBER). Rio Branco - AC, 2008.

DURKHEIM, E. Da divisão do trabalho social. 4.ed. São Paulo: Martins Fontes, 2010.

ELIAS, N. Escritos e ensaios 1: Estado, processo, opinião pública. Rio de Janeiro: Jorge Zahar, 2006.

FUNDAÇÃO BANCO DO BRASIL/IICA. Desenvolvimento regional sustentável: reflexões sobre a experiência do Banco do Brasil. Recife/ Brasília, 2008.

GAMBOA, L.H; CUNHA,L.H . A '(re)pecuarização’ do semi-árido nordestino: projetos territoriais e reconversões produtivas no cariri ocidental da Paraíba. VII Congresso Latino-americano de Sociologia Rural (ALASRU). Porto de Galinhas - PE , 2010.

GIDDENS, A. As conseqüências da modernidade. São Paulo: Editora da UNESP, 1991.

GOMES, R.; MENESES, V. As políticas públicas de incentivo a '(re) pecuarização' no semi-árido nordestino': desenvolvimento, modernização e recomposição espacial. VII Congresso Latino-americano de Sociologia Rural (ALASRU). Porto de Galinhas - PE , 2010. 
MULLER, P. L'analyse cognitive des politiques publiques: vers une sociologie politique de l'action publique. In: Revue Française de Science Politique, 50e année, n.2, p.189-208, 2000.

NEVES, D.P. Construção de novas competências para o desenvolvimento rural. In: MOTA, D. M; SCHMITZ, H.; VASCONCELOS, H. E. (Orgs.) Agricultura familiar e abordagem sistêmica. Aracaju, p.183198, 2005.

Mediações sociais e mediadores políticos. In: NEVES, D.P. (Org.) Desenvolvimento social e mediadores políticos. Porto Alegre/Brasília: Editora da UFRGS/PGDR, v. 1, p.21-44, 2008.

REVISTA SEBRAE AGRONEGÓCIOS - n.6, out., p.28-30, 2007. n. 4, dez. p. 12-15, 2006.

ROS, C.C. Mediação e conflito: lógicas de articulação entre agentes de promoção social e famílias camponesas, no norte da Província de Jujuy, Argentina. In: NEVES, D.P (Org.) Desenvolvimento social e mediadores políticos. Porto Alegre: Brasília: Editora da UFRGS/ PGDR, p. 99-129, 2008.

SARDAN, J.P. O. Antrophologie et développement : essai en socio -antrophologie du changement social. Paris: Éditions Karthala, 1995.

SEBRAE/PB. Capacitação de agentes de desenvolvimento rural (ADRs) para a caprinovinocultura. João Pessoa, 2003.

WANDERLEY, N. Agricultura familiar e campesinato: rupturas e continuidade. Estudos Sociedade e Agricultura. Rio de Janeiro, v. 21, p. 42-61, 2003.

WEBER, M. Ensaios de sociologia. In: GERTH, H.H; WRIGHT MILLS, C, (Orgs.) - 5. ed. - Rio de Janeiro: Guanabara Koogan, 1982.

A ética protestante e o "espírito" do capitalismo. São Paulo: Companhia das Letras. 2004. 
Parte 3 



\section{Políticas Públicas e Conversões Sociais: os beneficiários em cena}

Pedro Fonseca Leal

${ }^{66} \mathrm{Nas}$ análises sobre políticas públicas objetivadas em programas públicas, é recorrente os autores se pautarem em perspectivas que privilegiam o caráter avaliativo, apontando para o sucesso ou o fracasso da política. Por esta abordagem, tais autores limitam suas análises nos objetivos explicitados nos programas; nos critérios de seleção dos beneficiários; nos recursos previstos e os de fato destinados aos beneficiários; nas ações dos mediadores sociais vinculados às instituições gestoras do programa para que os beneficiários ajam de acordo com o que está definido nos regulamentos dos programas; nos beneficiários, buscando identificar se o programa está adequado ao público alvo e se os beneficiários têm condições de gerir os recursos a eles destinados, em conformidade ao estabelecido nos regulamentos dos programas; entre outros aspectos. Nesta perspectiva, a idealização da política pública se constitui como caráter marcador das análises. Os autores buscam recorrentemente identificar o que foi e o que não foi realizado, pensando os programas tal qual estão formulados. Os agentes institucionais ou agentes da mudança tendem a ser reconhecidos como mero reprodutores/executores das ações previstas nos regulamentos e os beneficiários são tidos, muitas vezes, como meros

66 Professor da Universidade Federal do Oeste do Pará, Doutor em Antropologia pela Universidade Federal Fluminense. 
receptores, como na "metáfora da esponja na água" ${ }^{67}$ que a tudo absorve. Dessa forma, a análise do sucesso ou fracasso das políticas públicas fica reduzida ao programa, à adequação das ações dos agentes institucionais e ao grau de adesão dos beneficiários.

Nesta perspectiva, não há uma reflexão que considera a própria política pública, bem como os programas, como uma forma de idealização produzida por agentes estatais sobre problemas na sociedade e a forma de resolvê-los, sendo, portanto, ela mesma uma forma de idealização da sociedade ou de parte dela; os agentes sociais em relação (mediadores institucionais e beneficiários) não são reconhecidos como sujeitos de ação e de reflexão sobre suas ações, assim como os beneficiários não são, muitas vezes, reconhecidos como portadores de projetos próprios. Assim, reduzir a análise dos processos de implantação de políticas públicas ao sucesso ou ao fracasso é negar aos agentes envolvidos a condição de sujeitos de ação e reflexão que tomam tais políticas e programas como possibilidade de ter seus projetos, pelo menos, em parte realizados.

Buscando contribuir para ultrapassar os limites impostos pela perspectiva apresentada anteriormente e aderindo à proposição para a organização da coletânea, conforme explicitado na apresentação, neste terceiro eixo, tomamos alguns casos de reflexão que incidem sobre a capilaridade dos segmentos populacionais envolvidos no acesso de recursos ou na institucionalização de posições desenhadas como parte dos objetivos de politicas desdobradas em programas. Nesta breve introdução à Parte III da coletânea, não pretendo discorrer sobre definições de políticas públicas, uma vez que esse investimento já foi realizado na introdução à Parte I, mas quero chamar a atenção para alguns pontos que serão abordados nos textos e que julgo merecerem destaque. 0 primeiro deles é o caráter uniformizante e seletivo da política pública, tornando-se, por conseguinte, promotora de enquadramentos para os que tentam se colocar ou se manter como beneficiários do programa. 0 segundo é o caráter transformador atribuído à política pública.

67 Reflexão oportunamente elaborada por Neves (2008, p.36). 
No primeiro aspecto, ao agente demandante da condição de beneficiário, portanto, em busca de acesso a recursos disponibilizados por agentes estatais, é imposto que ele conheça, pelo menos em parte, tanto a engenharia que conforma as redes de relações na qual busca se inserir ou se manter, como os atributos necessários para alcançar ou manter tal posição. Assim como proposto por Goffman (1975), ao analisar a interação social, neste processo, o demandante deve cumprir com as etapas descritas na norma do programa ao qual deseja se engajar e ao mesmo tempo representar o papel que corresponda ao personagem que os agentes estatais responsáveis por selecionar os usufrutuários querem ver. Portanto, tornar-se beneficiário é corresponder aos atributos descritos nos regulamentos da política pública e conhecer os meandros burocráticos, técnicos e políticos, isto é, os agentes e agências, as leis e as regras que objetivam a política pública.

No entanto, a luta para alcançar ou manter a condição de beneficiário de políticas públicas não faz o agente demandante se transformar tal qual o exposto nos regulamentos ou aderir por completo àquele modelo, como numa metamorfose. Nas políticas públicas, sobretudo aquelas destinadas a agricultores ou agroextrativistas que têm na base da organização da produção os membros da família, advoga-se a intenção de constituição de agentes ou beneficiários modulares, enquadrados, correspondentes e adeptos a formas específicas de produzir, de se organizar política e economicamente e de se relacionar com a terra e os recursos naturais. Tais formas modulares, previstas nos regulamentos dos programas públicos, marcam o caráter transformador da política pública. Transformação essa, muitas vezes, estimulada pela ação pedagógica de agentes estatais, mas geralmente levadas a cabo sob formas de constrangimento e alegando que a não adesão por parte do beneficiário poderá resultar em perda da posição, na limitação do acesso aos recursos e mesmo no fracasso do projeto definido na política pública. Por estas alegações, os agentes promotores da política pública põem em prática diversos mecanismos buscando reproduzir a relação tutelar sobre os beneficiários. Para tal, estão previstos a disponibilização de recursos financeiros na forma de crédito, assistência técnica, equipamentos, infraestrutura, etc. 
Se os agentes vinculados ao poder estatal criam ou tentam pôr, em prática, mecanismos voltados à reprodução da relação tutelar, buscando a constituição de beneficiários modulares, os beneficiários se utilizam de estratégias para se manter nesta condição, mas com certa autonomia. Dessa relação, constitui-se o caráter relativo tanto da tutela, por parte dos agentes estatais, como da autonomia, por parte dos beneficiários.

Retornando à questão focalizada nesta parte da coletânea, os autores aqui reunidos tecem análises onde põem, em destaque, as estratégias e os arranjos elaborados pelos beneficiários que buscam ter seus interesses alcançados como máximo de autonomia. Os autores demonstram que a adesão quando ela existe é sempre relativa. Mesmo porque, a execução dos programas que compõem a política pública também é relativa e, muitas vezes, parcial, conforme já apresentado. É nesse jogo de realizações e adesões relativas e/ou parciais que se constrói o espaço adequado apara construção de novas formas de apropriações e de ressignificações das políticas e programas públicos por parte, sobretudo dos beneficiários. Assim, as irrealizações, tão criticadas por certos analistas e agentes públicos, constituem-se aspecto fundamental, sobretudo, para que os beneficiários encontrem espaços para impor seus projetos. Dessa forma, no campo de análise de políticas e programas públicos, aquilo que pode ser reconhecido como fracasso aos olhos do avaliador ou do administrador da política pública, pode ser a saída à realização do projeto daquele que se constituiu na condição de beneficiário, possibilitando, inclusive, rearranjos até então impensados.

É por adotar tal perspectiva que os textos de Gimima Beatriz Melo da Silva e Rodrigo Pennutt da Cruz estão aqui reunidos. Ambos valorizam os múltiplos engajamentos e conversões produzidos pelos agentes beneficiários das políticas de regularização e redistribuição fundiária para alcançar certa autonomia no processo de condução e execução de tais políticas.

Ao buscar entender os mecanismos e os desdobramentos das políticas de planejamento territorial e ambiental, postas em prática por gestores públicos vinculados tanto ao governo federal 
como ao governo estadual, no Estado do Amazonas, Gimima Beatriz Melo da Silva foca suas análises nos moradores da Reserva de Desenvolvimento Sustentável do Rio Negro, localizada no município de Novo Airão, criada pelo governo do Estado do Amazonas. A autora define da seguinte forma seu objeto de pesquisa:

A partir de narrativas dos habitantes da RDS do Rio Negro, localizada na Região do Baixo Rio Negro, neste texto, qualificados como beneficiários de um programa de recompensa por serviços ambientais, enfoco a dinâmica e o inerente simbolismo das relações de poder constituídas em processos que envolvem a gestão territorial e ambiental nesta região. Este exercício se configura analiticamente no bojo de políticas públicas tecidas para referenciar a alcançar a sustentabilidade como valor universal e universalizante. Compreendendo tais ações no plano local, posso trazer à análise o cenário de consolidação das ações que envolvem tais outros comportamentos dos habitantes da RDS do Rio Negro, isto é, agentes econômicos que, em tese, devem internalizar formas diferenciadas de exploração dos recursos naturais contidos no interior da Reserva onde habitam. (Gimima Beatriz Melo da Silvainformação verbal)

Buscando compreender os mecanismos e estratégias postos em prática pelos agentes estatais para alcançarem os objetivos propalados nos regulamentos que orientam a criação de espaços destinados privilegiadamente à conservação dos recursos naturais, a autora analisa a legislação que fundamenta tais políticas, pondo, em destaque, os argumentos que justificam a criação de unidades de conservação no Estado do Amazonas e a importância da população residente no interior dessas áreas para os objetivos finalísticos da política. Neste contexto de política governamental que associa 
conservação da natureza e melhoria da qualidade de vida da população, os agentes locais passam a ser reconhecidos pelos agentes governamentais como possíveis parceiros para alcançar a tão propalada sustentabilidade verde.

Porém, demonstra a autora que mesmo sendo reconhecidos como parceiros na conservação dos recursos naturais, os moradores da RDS do Rio Negro devem, em tese, assumir novos valores e práticas que passarão a orientar suas relações com o território. $\mathrm{Na}$ situação empírica analisada, ela coloca, em destaque, o Programa Bolsa Floresta, adotado por agentes estatais como mecanismo privilegiado com o intuito de construir a adesão dos moradores da reserva aos objetivos da política de conservação da natureza e, portanto, da sustentabilidade verde. Por esta forma de adesão, mediada pelo acesso aos recursos disponibilizados a partir do Programa Bolsa Floresta, os moradores da RDS Rio Negro passam à posição de "guardiões da floresta" por se tornarem fiscais da natureza com o intuito de reduzir as taxas de desmatamento por derrubada ou queimada. Neste aspecto, o programa de pagamento por serviços ambientais (no caso em apreço o Bolsa Floresta), visa a diminuir os impactos causados pela proibição ou limitação imposta aos moradores da reserva para realizar certas atividades, sobretudo econômicas. Segundo a autora,

O auxílio em dinheiro, concedido por meio do Programa Bolsa Floresta, é entendido pelos porta-vozes do governo como um incentivo necessário para que os beneficiários do programa evitem, em suas atividades produtivas, a adoção de práticas que promovam o desmatamento. (Gimima Beatriz Melo da Silva $\square$ informação verbal [s.d.])

No texto "Rearranjos locais no Programa de Reforma Agrária: estudo de caso do P.A. Che Guevara (Campos dos Goytacazes, RJ)", de autoria de Rodrigo Pennutt da Cruz, o foco da análise recai sobre o Programa Nacional de Reforma Agrária, gerido pelos agentes vinculados ao Instituto de Colonização e Reforma Agrária (INCRA), e 
mais especificamente sobre o processo de constituição dos beneficiários da reforma agrária sob a condição de assentados. Para tanto, o autor analisa,

Alguns dos meandros da aplicação do Programa Nacional de Reforma Agrária, considerando, em especial, as interferências e negociações decorrentes dos percursos de relações vividos pelos trabalhadores selecionados para alcançarem a condição de assentados no Projeto de Assentamento (P.A.) Che Guevara, criado no município de Campos do Goitacazes, no Estado do Rio de Janeiro (CRUZ, 2010).

Buscando compreender o processo de constituição do agricultor qualificado como assentado por ser beneficiário do programa nacional de reforma agrária, o autor observa:

No processo de aplicação de política pública de redistribuição de terra, fundamentada em quadros institucionais diferenciados e objetivados por Projetos de Assentamento, por perspectiva simplificada tem-se como dada a construção da categoria situacional assentado. Se há definições oficiais, constantes de documentos que registram e pressupõem normatizar o processo de assentamento, há condições possíveis e até imprevistas de realização.

Adotando tal perspectiva, Rodrigo Pennutt da Cruz desenvolve sua análise confrontando diferentes formas de os beneficiários se constituírem enquanto tal, tomando como referência suas trajetórias de vida e de luta pelo acesso a terra. Por texto, o autor pretende "contribuir para o entendimento de processos pelos quais os trabalhadores rurais de origens diversas se deslocaram para a posição de assentados rurais; ou seja, conquista fundamentada no aprendizado de vinculação a campos de disputa e negociação como agentes políticos". 
Na situação estudada pelo autor, chama a atenção o fato de mesmo estando categorizados segundo a definição oficial na condição de assentados, há no PA Che Guevara múltiplas formas de classificação marcadoras de processos de diferenciação que põem os assentados em posições hierarquizadas tanto nas relações entre eles como na relação com os agentes estatais. No processo de assentamento, os agentes beneficiários adotam o local de origem, as formas de afiliações com o antigo patrão, o usineiro, e as relações com grupos de representação política, no caso Sindicato dos Trabalhadores Rurais e o Movimento dos Trabalhadores Rurais Sem Terra (MST) como princípios para a qualificação e diferenciação entre os beneficiários e, portanto, para a formulação dos termos classificatórios. Dessa forma, os termos os de dentro e os de forma definem posições distintas e agentes em concorrência no processo de assentamento do PA Che Guevara.

Dessa forma, o autor analisa processos que contribuem para a constituição de posições sociais, políticas e economicamente diferenciadas, observando que "o estudo do processo de mudança de trabalhadores em assentados rurais se associa ao das condições de construção relacional e situacional de identidades sociais, todavia relativizadas como expressão de relações de força e de sentido que aí se encontram em jogo".

Assim, os autores incluídos nesta parte da coletânea tomam os processos de mudança pelos quais passam os agentes beneficiários de programas públicos para pôr, em destaque, as múltiplas formas destes se constituírem, na relação com agentes estatais, enquanto sujeitos formuladores de projetos.

\section{Referências}

GOFFMAN, Eving. A representação do eu na vida cotidiana. Petrópolis: Ed. Vozes, 1975.

NEVES, Delma Pessanha. Mediação social e mediadores políticos. In: (org). Desenvolvimento social e mediadores políti-

cos. Porto Alegre: Editora da UFRGS, p.21-44, 2008, 


\section{VIII}

\section{Gestão Ambiental e desautorizações dos moradores em RDS: Reserva de Desenvolvimento Sustentável - do Rio Negro-AM}

Gimima Beatriz Melo da Silva ${ }^{68}$

O município de Novo Airão, no Estado do Amazonas, é cenário do exercício da pesquisa aqui textualizada, situação onde a gestão territorial, objetivada por instituições vinculadas tanto ao aparato do governo estadual quanto federal, também compõe um mosaico territorial construído pela orientação da política ambiental. Esta se apresenta como promotora de um novo paradigma de comportamento comunitário e cidadão, a ser politicamente desejada como prática cotidiana pelos moradores das comunidades tradicionais vis a vis o ambiente em que vivem. Esse novo comportamento, fruto de uma orientação ambientalista que se destina ao ordenamento no âmbito local, mas que se configura segundo referências elaboradas em nível global, cria situações em que, muitas vezes, o componente ambiental se sobrepõe ao social, desde que avaliado em termos de prioridade nos objetivos a serem atingidos com as ações de gestão territorial e ambiental, tais como adotadas pelas diferentes esferas governamentais de gestão.

A partir de narrativas dos habitantes da RDS do Rio Negro, localizada na Região do Baixo Rio Negro, neste texto, qualificados como beneficiários de um programa de recompensa por

68 Professora da Universidade do Estado do Amazonas, doutoranda em Antropologia pelo PPGA/UFF, bolsista do Programa RH-Doutorado-FAPEAM - gbeatriz2008@ hotmail.com/gbsilva@uea.edu.br 
serviços ambientais, enfoco a dinâmica e o inerente simbolismo das relações de poder constituídas em processos que envolvem a gestão territorial e ambiental nesta região. Este exercício se configura analiticamente no bojo de políticas públicas tecidas para referenciar a alcançar a sustentabilidade como valor universal e universalizante. Compreendendo tais ações no plano local, posso trazer, à análise, o cenário de consolidação das ações que envolvem tais outros comportamentos dos habitantes da RDS do Rio Negro, isto é, agentes econômicos que, em tese, devem internalizar formas diferenciadas de exploração dos recursos naturais contidos no interior da reserva onde habitam.

Assim enfocando as práticas de objetivação daquelas intenções políticas, não se pode perder de vista que opero analiticamente em cenário de ações pouco autônomas para os moradores de comunidades oficialmente qualificadas tradicionais, ou seja, aquelas que habitam o polo 01 da RDS do Rio Negro. Estão seus habitantes constrangidos a promover atividades produtivas que se coadunem com os objetivos do programa de pagamento por serviços ambientais, o Bolsa Floresta, recurso instrumental básico para consolidar, em nível estadual, as ações impetradas pelos distintos níveis nacionais e internacionais de gestão.

\section{0 munícipio de Novo Airão}

Novo Airão está localizado na margem direita do Rio Negro, a uma distância de $115 \mathrm{~km}$ de Manaus-AM, em linha reta. Seu acesso por meio fluvial é de $130 \mathrm{~km}$ (8 horas) e pela Estrada AM 070, Manaus/Manacapuru, no $\mathrm{km} \mathrm{75,} \mathrm{quando} \mathrm{se} \mathrm{tem} \mathrm{acesso} \mathrm{à} \mathrm{AM} \mathrm{352,}$ percorrendo-se mais $98 \mathrm{~km}$ até a cidade, percurso esse realizado em até 3 horas de viagem. 


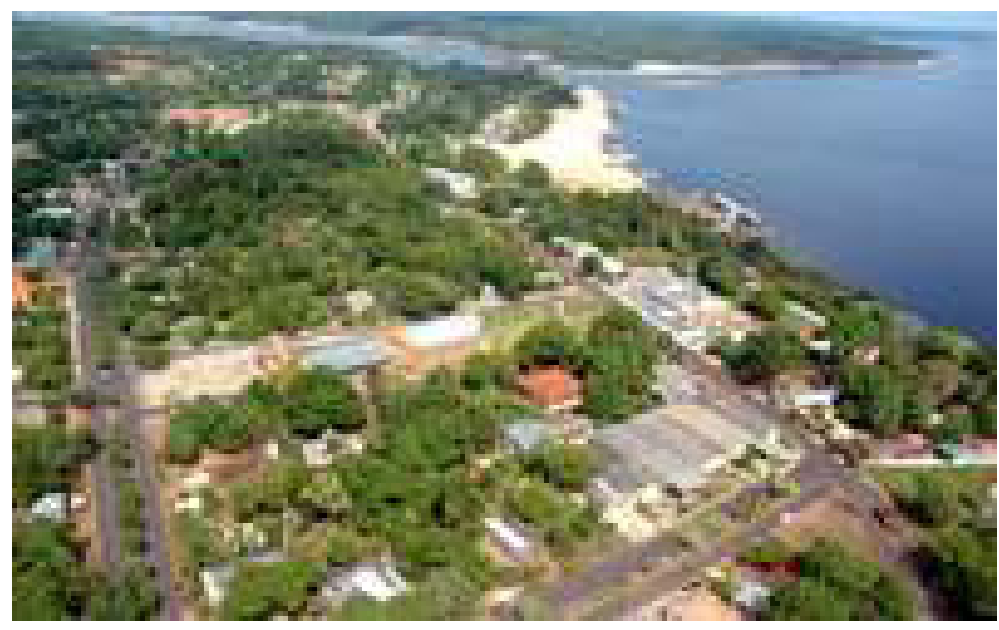

FOTO - Vista aérea de Novo Airão-Am

FONTE - Escaneada de cartão postal público

O povoamento da região teve início com ocupações das áreas ribeirinhas do Rio Negro, no século XVII. Em 1668, aparece um povoado nas proximidades da foz do Riacho Aruim, depois mudado para foz do Rio Jaú. Em 1759, seguindo as ordens do Marquês de Pombal, o nome atribuído ao povoado passa a ser Airão.

Durante muitos anos, o conhecimento das condições de vida dos moradores de Airão estava muito circunscrito ao plano local; ou aos que vivem o cotidiano das famílias aí residentes. Tanto é que, em 1950, as ruínas que marcaram a história do município encontravam-se em estado precário e hoje passam por um processo de tombamento pelo Instituto de Patrimônio Histórico Brasileiro (Iphan). Essas ruínas são compostas de 11 edifícios, do cemitério e da igreja do século XVIII, um símbolo da cidade. Há ainda, espalhados por Novo Airão, inúmeros sítios arqueológicos, todos do tipo petróglifo (gravações em pedras). Existem também pontos de habitações e acampamentos da época pré-histórica. 


\section{Cenário Econômico}

A base da economia de Novo Airão assenta-se no setor secundário, pois o setor primário pouco contribui para sua economia. Naquele setor, pode-se destacar a construção de embarcações regionais, movelarias, serrarias, uma marcenaria, uma fábrica de gelo e uma olaria. No setor primário, a maioria dos produtos agrícolas e pecuários é destinada à subsistência. Pode-se relacionar, neste setor, um reduzido rebanho de gado bovino, aves domésticas, frutas regionais e mandioca, estando a atividade agrícola concentrada na produção de farinha e banana.

A agricultura praticada é de subsistência. Cultivam-se pequenas roças com área média de um hectare, por um período de aproximadamente dois anos e pousio de cinco anos. Essa prática agrícola obedece às técnicas tradicionais indígenas, ou seja, derrubam a mata, queimam a vegetação, coivaram e plantam, principalmente, a mandioca, banana, abacaxi, abacate, açaí, cupuaçu, milho e algumas verduras e legumes, com destaque para a comercialização da melancia.

O extrativismo baseia-se na exploração vegetal: a borracha, outras gomas e a castanha (em pequena escala). Em maior escala, as madeiras, como o louro-inhamuí, louro-preto, jacareúba, itaúba, copaíba, andiroba, macacaúba. Os principais pontos de extração da madeira são: Novo Airão, Igarapé Açu, Igarapé do Câmara e Igarapé Tumbira.

Ressalta-se, ainda, o artesanato local como atividade econômica e cultural, que requer o uso dos recursos naturais da região pelos moradores locais. A fabricação de biojoias tornou-se uma alternativa econômica utilizada principalmente pelas moradoras da comunidade Tiririca, a primeira comunidade localizada no polo 01 da Reserva de Desenvolvimento Sustentável do Rio Negro. 


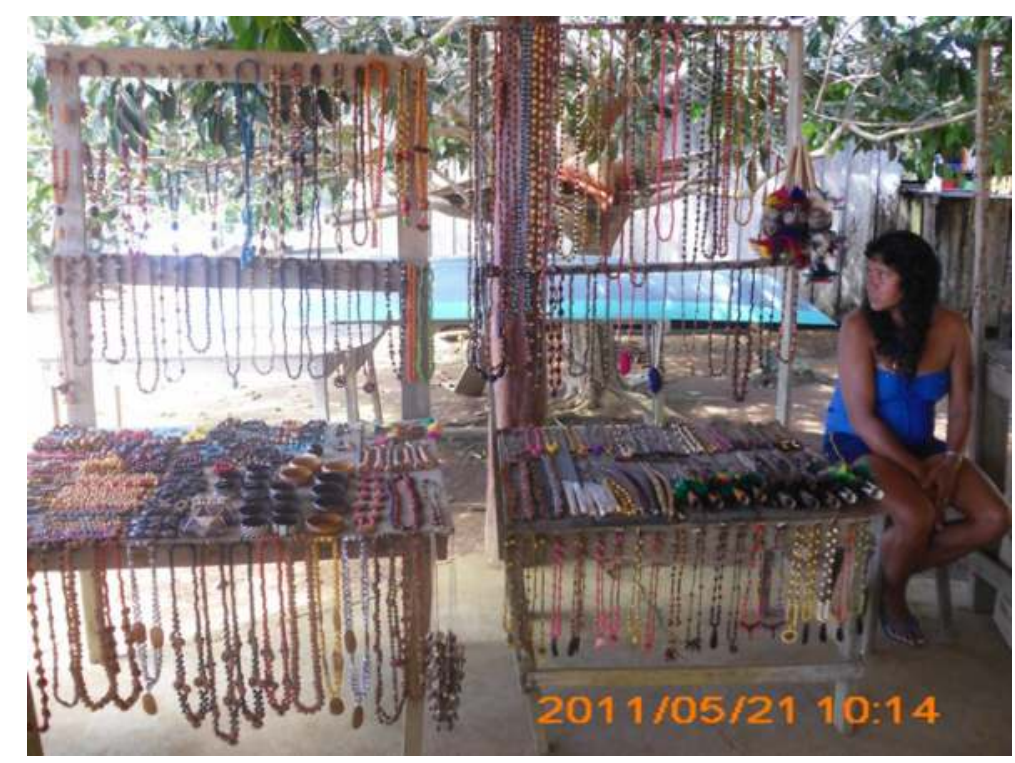

FOTO - Comércio de Artesanato em Novo Airão

FONTE- Foto Gimima Beatriz Melo da Silva, maio 2011

São muito utilizados os produtos extrativistas, como a palmeira arumã (Calathea sp.), o cipó-titica (Heteorpsis spruceana), o cipótimbó (Derris sp.) e outros. O artesanato de Novo Airão ganhou destaque internacional depois do surgimento da organização não governamental Fundação Almerinda Malaquias que, há doze anos, gerencia a atividade no município. A Ong se dedica à luta contra a extinção do peixe-boi e ao processo de conscientização e educação ambiental, envolvendo crianças, através de projetos desenvolvidos com a ajuda da Association Ailleurs Aussi, Suíça. Os projetos incluem uma escola silvestre, com o objetivo de manter e conservar $32 \mathrm{hec}-$ tares de floresta.

O turismo ecológico vem se firmando como uma alternativa econômica em Novo Airão. O Parque Nacional de Anavilhanas figura como um grande atrativo turístico do município de Novo Airão. No período da vazante dos rios, que no Amazonas ocorre entre os meses de julho e dezembro, são inúmeras as praias que surgem, fazendo então emergir um movimentado comércio na 
cidade de Novo Airão, com a frequente presença de turistas que buscam as pousadas locais, hotéis de selva, unidades de prestação de serviços que oferecem passeios ecológicos diurnos e noturnos. Além disso, um dos maiores atrativos no município, qual seja alimentar os botos vermelhos e com eles nadar no Rio Negro.

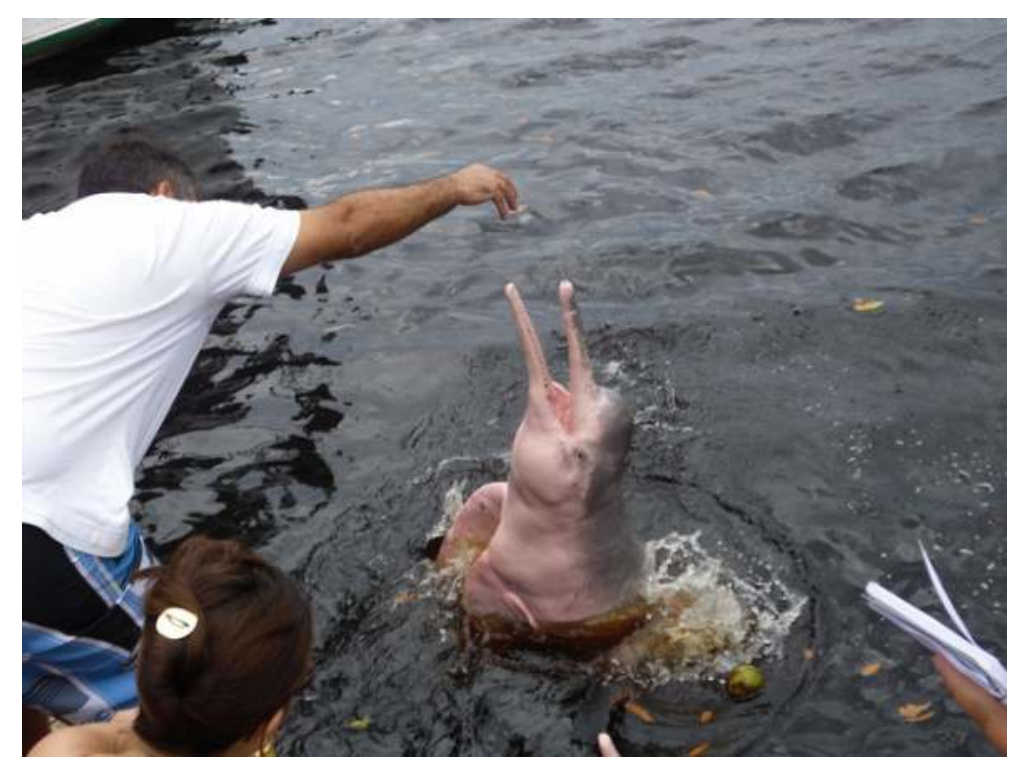

FOTO -Turista com boto vermelho em Novo Airão FONTE - Gimima Beatriz Melo da Silva, julho 2010.

A ilha mais próxima da sede do município fica a 2,5 km de distância. Nela, um grande número de lagos é visitado por pescadores artesanais, que têm permissão somente para essa modalidade de pesca, tendo em vista a proibição de atividades como caça e pesca no interior dos parques.

Comumente, nas fachadas das casas, há placas com anúncios de oferta de passeio de lancha para o Arquipélago de Anavilhanas; embora o Instituto Chico Mendes de Conservação da Biodiversidade - ICMBio tenha uma presença forte de controle, tanto em relação ao Parque Nacional de Anavilhanas quanto ao acesso ao Parque Nacional do Jaú. 


\section{A dinâmica da Regulação Fundiária em Novo Airão-AM}

Ao longo da rodovia AM-352, Manaus-Novo Airão, chama atenção a movimentação de habitações recentes, ainda que haja toda uma ação de interdição pelo Instituto de Terras do Estado do Amazonas - ITEAM, que afixa placas de advertência quanto ao crime de grilagem de terras públicas. Esses anúncios já são percebidos desde o porto do Cacau Pirêra, onde atracavam as balsas que, até outubro de 2011, faziam a travessia do Rio Negro, de Manaus para aquela localidade. Neste momento, estabeleceu-se a ligação da capital Manaus com os municípios de Iranduba, Manacapuru e Novo Airão, mediante a inauguração da Ponte Rio Negro. A cerimônia foi estrategicamente realizada no dia 24 de outubro de 2011, data do aniversário da cidade de Manaus, constituindo-se em evento que contou com a presença de autoridades locais, como prefeitos das cidades envolvidas, o governador do Estado do Amazonas, senadores do Amazonas e a presidente da República.

O município de Novo Airão, nos últimos anos, tem sido objeto de recorrentes processos de grilagem, processos agravados com o advento da construção da ponte sobre o Rio Negro, visto que hoje liga, com mais rapidez, aquele município a Manaus, e com ele, os municípios de Manacapuru e Iranduba. Oferecendo acesso mais rápido, a interligação entre as referidas cidades levou à especulação imobiliária, fato que tem motivado a campanha de advertência que atualmente o ITEAM impetra quanto a esse crime naquela região.

A intensificação de uma onda de invasões, explicitadas pelas queimadas por elas provocadas, é visível às margens dessa rodovia. Elas foram frequentes em 2009; e em julho de 2010, voltaram a se intensificar, causando prejuízo aos moradores que possuem títulos legalizados, pois as queimadas saem do controle e invadem propriedades antigas. Esse fato levou a gestão da prefeitura do município a anunciar um Plano Municipal de Combate às Queimadas, com o objetivo de fiscalizar e proteger toda a zona rural do município. 


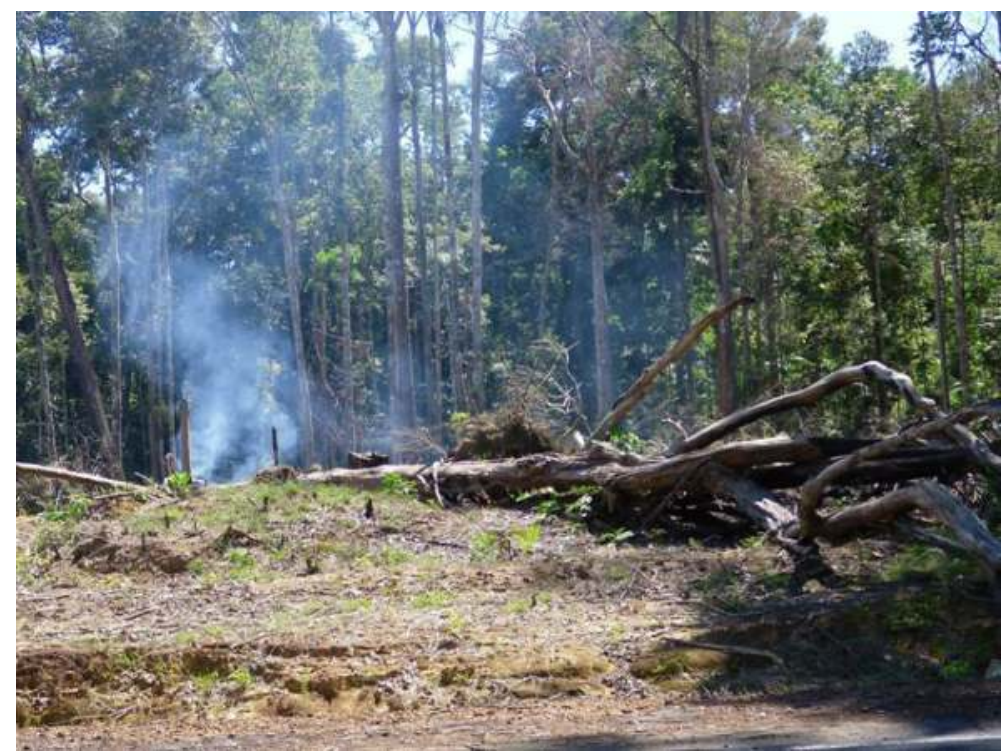

FOTO - Queimada ativa na estrada de acesso a Novo Airão

FONTE - Gimima Beatriz Melo da Silva, julho 2010

No Amazonas, como nas demais unidades da federação, o ordenamento territorial vincula-se à necessidade de regularização fundiária, cujo processo, por sua vez, está diretamente relacionado ao conjunto de fatores econômico, político e socioambiental que estruturam a organização do espaço territorial, sua ocupação, destinação e, assim, o controle das terras públicas. O conflito pelo acesso à propriedade da terra contribuiu para o aparecimento de uma legião cada vez maior de posseiros em situação irregular, tornando-se excluídos de programas e iniciativas da esfera governamental.

Isso tem gerado condições propícias para a instalação de grandes empresas madeireiras que, vindo a se favorecer pela precariedade de alternativas econômicas da população local, realizam suas atividades de forma predatória. Por consequência, no Estado do Amazonas, a aceleração do desmatamento vem contribuindo para o aumento incontrolável de grilagem em terras públicas. 


\section{O Mosaico do ordenamento territorial no Baixo Rio Negro}

O município de Novo Airão possui uma extensão territorial de $37.771,2 \mathrm{Km}^{2}$ e, atualmente, $80 \%$ dessa área é protegida por unidades de conservação ou reservas indígenas, o que instiga a uma análise do seu atual contexto territorial. Localizado às margens do Rio Negro, o município dá acesso, entre outras, a duas grandes áreas de proteção ambiental: o Parque Nacional de Anavilhanas e o Parque Nacional do Jaú. Nesse processo, a região apresenta-se como um verdadeiro mosaico no que tange à visualização políticoterritorial desses espaços, como é possível conferir na imagem a seguir.

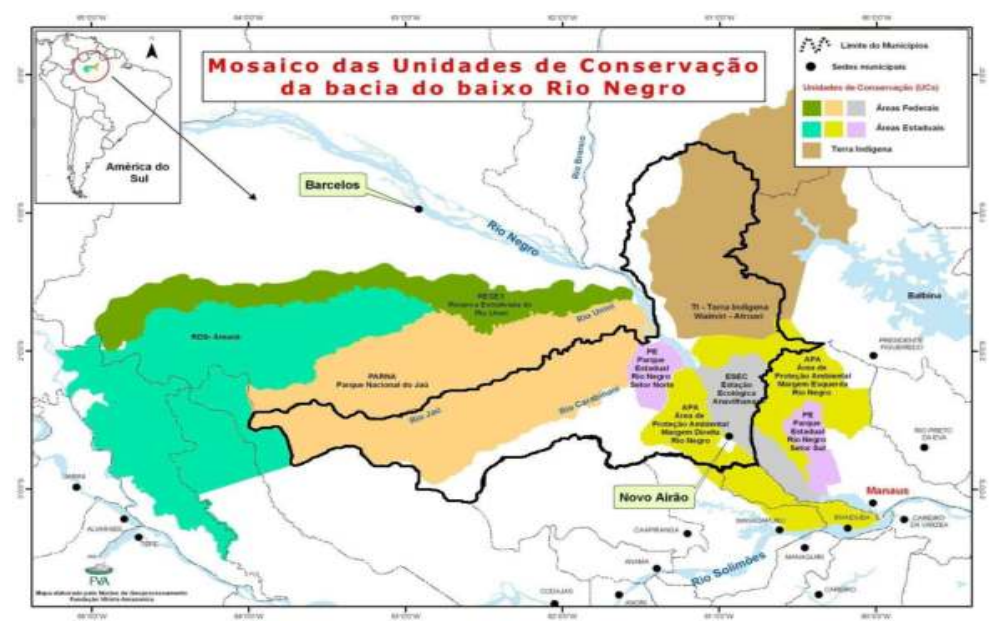

IMAGEM - Mosaico das unidades de conservação da bacia do Baixo Rio Negro

FONTE- Fundação Vitória Amazônica

O Parque Nacional de Anavilhanas, assim denominado desde outubro de 2008, antes denominado Estação Ecológica de Anavilhanas, criada em 1981, é um dos maiores arquipélagos fluviais do mundo, localizado numa área de 350.018 hectares. Comporta uma formação de cerca de 400 ilhas, que se transformam num atrativo turístico no período da vazante dos rios. Estando na 
categoria II de áreas protegidas, o Parque Nacional constitui-se em área protegida, manejada principalmente para a conservação de ecossistemas e com fins de recreação.

O Parque Nacional do Jaú, criado em 1980, com uma área de 2.272.000 ha, é sítio do Patrimônio Natural Mundial da UNESCO. Situa-se a $220 \mathrm{~km}$ de Manaus. É o maior parque nacional do Brasil e o maior parque do mundo em floresta tropical semiúmida e intacta. O nome Jaú, oriundo do tupi, denomina um dos maiores peixes brasileiros e também o rio que banha o Parque. A região constitui uma importante amostra dos ecossistemas amazônicos. Os estudos botânicos desenvolvidos no Parque, até o momento, apresentam cerca de 400 espécies de plantas. Várias destas espécies estão restritas a determinados ambientes ali encontrados. As matas de igapó e de terra firme possuem composições de plantas totalmente diferentes. Espécies como a Macaricuia e o Macucu do igapó só são encontradas em matas inundadas. Muitos pesquisadores têm encontrado rica e diversificada fauna no Parque, até o momento estando catalogadas 263 espécies de peixes, algumas até então não conhecidas pela ciência.

Esse parque constitui-se em Unidade de Conservação Ambiental sob controle mais rígido pelo ICMBio, uma vez que famílias que já habitavam o interior do Parque, antes de ele ser criado administrativamente, têm passado por um processo que Santos (2002, p.26) denominou de ambientalização, ou seja “...o processo levado a cabo por uma proliferação discursivo-técnico-científica articulada em todos os âmbitos da vida econômica, política e cultural moderna que transforma a natureza em ambiente."

Luiz Fernando de Sousa Santos parte da ideia de que, no discurso ambientalista contemporâneo, com o exercício do biopoder, a natureza foi transformada em ambiente, os territórios reconfigurados em função do equilíbrio ecológico da terra. E grupos sociais diversos foram transformados em sociedades ecologizadas, biologizadas e ambientalizadas.

O efeito da emergência da questão ambiental tem se mostrado na reafirmação da necessidade de uma vigilância ambiental, redimensionando assim o discurso das corporações e agências estatais. 
Consequentemente, a realidade social desses habitantes de áreas protegidas se adéqua a uma nova ordem, que traz consigo uma nova conduta, estabelecida a partir da autoridade que exerce poder e cria um discurso performativo.

Em conversa com moradores locais, percebe-se certa insatisfação quanto à presença do ICMBio regulando esse acesso, bem como (re)nomeando espaços antes configurados por princípios próprios de territoriazação (ou apropriação coletiva), portanto, reconhecidos pelos moradores por outras categorizações. Registrados por esse instituto com outras formas de denominação, com elas, os aí nativos não se identificam. É o caso de um lago chamado pelos moradores locais de "Lago Apacú" e denominado pelo ICMBio de "Lago do Carão".

[...] o IBAMA [hoje ICMBio] deu o nome de Carão, mas nós caboclos daqui conhecemos como lago do Apacú [...] Apacú ou Carão, mas o povo conhece mais como Apacú aí na cidade. (entrevista realizada com morador da sede do município de Novo Airão em 10/07/2010).

Na narrativa do morador local, percebe-se o quanto ele se preocupou em enfatizar a dupla denominação que o lugar possui, sendo uma delas mais utilizada, por ser, aparentemente, aquela com a qual mais se identifica.

O estudo de unidades de conservação contempla a discussão conceitual do território sob várias abordagens (biológica, cultural e econômica), além da possibilidade de propiciar a análise da problemática da desterritorialização, hoje tão importante no campo de embate diante de investimentos por apropriação capitalista e preservação ambiental.

O processo de criação das unidades de conservação, no mundo atual, vem se constituindo numa das principais formas de intervenção governamental. E, no Amazonas, não é diferente. Esse processo, segundo o discurso construído no interior da instituição estatal, visa a reduzir as perdas da biodiversidade face à degradação ambiental imposta pela sociedade (desterritorialização 
das espécies da flora e fauna). Entretanto, esse processo tem sido acompanhado por conflitos e impactos decorrentes da desterritorialização de grupamentos sociais (tradicionais ou não), em várias partes do mundo.

Dessa forma, considera-se que o processo de criação de espaços territoriais como Unidades de Conservação está impregnado de relações de poder, no sentido aplicado por Bourdieu (1998). O campo em que se dá a atuação do Estado, exercendo seu poder de regulamentar um novo paradigma de relacionamento, é o mesmo onde se dá a relação pré-estabelecida entre o homem e a natureza, mas segundo moldes que não sofriam anteriormente uma intervenção externa.

Nesse contexto, o exercício do poder público se encontra atrelado à Política Nacional de Meio Ambiente, pela qual está contemplada a criação de Unidades de Conservação como orientação de ordem social mais ampla; ou que assume dimensões planetárias, no sentido de adotar novos paradigmas na relação estabelecida entre a pressuposta subdivisão entre ambiente social e natural. Ao criar as áreas de conservação, os porta-vozes do Estado estabelecem um caráter impositivo diante dos moradores dessas áreas, redirecionando suas práticas em relação àquele meio.

\section{A Reserva de desenvolvimento sustentável do Rio Negro e os guardiões da floresta}

Os textos a seguir, comentados, integram a lei complementar n. 53, de 05 de junho de 2007, que cria o Sistema Estadual de Unidades de Conservação - SEUC; e a lei n. 3.355, de 26 de dezembro de 2008, que cria a Reserva de Desenvolvimento Sustentável do Rio Negro. Eles podem ser considerados como estratégias de difusão do ideário que associa a conservação da biodiversidade à qualidade de vida da população que habita em áreas protegidas. Nesta última investidura jurídico-administrativa, pode-se supor que o argumento da preservação ambiental chega com mais poder de persuasão aos 
moradores das áreas alvo de políticas ambientais de caráter conservacionista, ao contemplar ações de ordenamento territorial.

Art. 4.. O SEUC tem os seguintes objetivos: (...) - promover o desenvolvimento sustentável e a melhoria da qualidade de vida das populações locais, regionais e globais, especialmente das comunidades tradicionais (Lei complementar n. 53 de 05/06/2007, grifo nosso):

Art. $3^{\circ}$ - A RESERVA DE DESENVOLVIMENTO SUSTENTÁVEL DO RIO NEGRO tem como objetivo básico preservar a natureza e, ao mesmo tempo, assegurar as condições e os meios necessários para a reprodução e a melhoria dos modos e da qualidade de vida e manejo dos recursos naturais pelas comunidades tradicionais, bem como valorizar, conservar e aperfeiçoar o saber e as técnicas de manejo do ambiente, desenvolvido por essas populações. (Lei 3.355, de 26/12/2008, grifo nosso)

Dessa forma, a gestão ambiental pressupõe, muitas vezes, a gestão do ordenamento territorial. Tanto é que os dados percentuais revelam um cenário que denota o estabelecimento de um Estado pautado na busca de um novo comportamento frente às questões ambientais de nível local, mas também promovendo reflexos em nível global. Como exemplos, desfilam-se dados estatísticos frequentemente divulgados, que se reportam à redução do desmatamento no interior da Região Amazônica, mais precisamente nas áreas protegidas, como as RDS's do Amazonas. Por outro lado, o aspecto do exercício do poder, tão bem enfatizado nas análises de Pierre Bourdieu (1998), toma corpo quando, por exemplo, se verifica que, entre 2003 e 2006, houve um aumento de quase $128 \%$ na superfície das Unidades de Conservação Estaduais - UCE. Ela passou de 7,4 milhões de hectares, até 2002, para 16,9 milhões de 
hectares, em 2006. Atualmente, as UCE somadas às federais correspondem a mais de $22 \%$ da superfície total do Estado. Além disso, há 45,7 milhões de hectares de terras indígenas, das quais mais de $85 \%$ já foram demarcadas.

Ressalta-se, ainda, que os moradores de comunidades tradicionais, que habitam em áreas protegidas na região do Baixo Rio Negro, apresentam uma história de animosidade estabelecida com as instituições responsáveis pela gestão e fiscalização dessas áreas. Como exemplo mais emblemático dessa relação de animosidade, pode ser considerado o episodio referente à criação do Parque Nacional do Jaú. Esse Parque Nacional foi criado de forma sobreposta a uma área de quilombo, onde já havia moradores que tinham a base de sua atividade econômica na exploração dos recursos naturais. A criação desse Parque foi objeto de vários estudos acadêmicos, entre os quais destaco o realizado por Santos (2002), que explorou o fenômeno a partir da noção de biopoder desenvolvida por Pierre Bourdieu.

No período que se seguiu à criação do Parque, a fiscalização foi intensificada pelo Instituto Brasileiro de Meio Ambiente - IBAMA, impondo aos habitantes locais uma situação de autovigília constante. Mesmo assim, as atividades, agora proibidas, de exploração de recursos naturais, madeira, pescado, cipós etc., continuaram a ser realizadas de forma clandestina, levando a muitas apreensões, autuações e gerando constantes conflitos.

Essa relação conflituosa pode-se supor tem origem na forma como as áreas protegidas, como o Parque Nacional do Jaú e o de Anavilhanas, foram criadas na Região do Baixo Rio Negro: antes de 2003, ou seja, sem a base democrática da participação comunitária, que promove a comunicação entre as instituições de gestão e os habitantes locais, tal como retratado na narrativa, a seguir, de um habitante da RDS do Rio Negro:

Nosso conflito sempre foi com o IBAMA. Então foram nossos amigos presos, e daí começouse um movimento, e daí o governo começou a se envolver. Nós começamos a nos manifestar, o governo começou a se envolver e 
nós começamos a debater de frente com ele sobre criação de Reserva sem consultoria da família, do morador que vivia ali, não tinha nenhum respeito com ele. E o IBAMA só queria prender, prender, e não traz solução, não mostra solução. E ai? A família vai viver de quê? Se for aquilo que foi passado de geração pra geração e todo mundo foi se habituando a cortar madeira e não tinha jeito, ninguém sabia fazer outra coisa? (...) O IBAMA ele só ia à comunidade atrás do caboclo que serrava, era aquele negócio (...) mas não trazia uma educação ambiental, uma solução, tipo: - Olha pessoal, precisa criar um plano de manejo pra que vocês possam trabalhar. (Entrevista com Morador da comunidade Terra-Preta em Novo Airão, maio de 2011- informação verbal)

No período compreendido entre 2003 e 2010, a gestão territorial estadual coaduna-se com a política ambiental traçada pelo governo federal para aquela Região, no sentido de implantar estratégias voltadas à redução do desmatamento e à exploração de recursos pesqueiros em escala comercial. Nesse sentido, a criação de Áreas de Proteção Ambiental tornou-se uma prática intensificada na Região, levando a um cenário onde cerca de $80 \%$ do município de Novo Airão configura-se em áreas de proteção. Estas áreas, sejam federais ou estaduais, contribuíram para a redução dos índices de emissão de carbono, o que numa escala global, acredita-se que contribua para o equilíbrio do clima no planeta.

Assim, percebe-se, nessa estratégia, o compromisso com a qualidade do ar em escala global, assumido pelo Estado brasileiro no período em análise. Entretanto, os componentes utilizados no plano das estratégias políticas de gestão têm natureza distinta. Por um lado, tem-se o aumento da fiscalização por parte do governo federal, que se dá através da criação de áreas de proteção ambiental de uso proibido, aumentando assim o contingente utilizado na 
fiscalização, que agora se faz por intermédio de dois institutos, a saber, o IBAMA e o ICMBio.

Por outro lado, no plano estadual, optou-se pela criação de Reservas de Desenvolvimento Sustentável, onde a exploração dos recursos é permitida, mas de forma controlada, bem como no envolvimento dos habitantes dessas áreas na sua fiscalização. 0 componente utilizado para esse envolvimento foi um programa de pagamento por serviços ambientais, aliado ao discurso no qual os próprios moradores se tornariam os fiscais, ou seja, os "guardiões da floresta", como é possível observar a partir da narrativa a seguir:

Com a primeira reunião que teve (...) o rapaz que veio lá, ele falou: - Olha, uma coisa eu vou falar pra vocês (...) essa reserva ela não é intocável pra vocês, sabe por quê? Isso aqui é sustentável, isso aqui é pra conservar. A conservação ela não é intocável não (...) vocês mesmos vão ser fiscais dentro da comunidade de vocês, não é preciso colocar fiscais não, vocês mesmos vão fiscalizar. Qualquer coisa, se não quiserem obedecer, vocês passam um rádio e aí a gente vai pegar aí na "boca" (do rio). (Entrevista realizada com morador da comunidade Nova Esperança, 68 anos, em maio de 2011- informação verbal)

A legítima significação que envolve a denominação aplicada ao Programa Bolsa Floresta atua como um elo entre o homem do interior e o meio em que vive. Leva-o a uma aceitação mais rápida das limitações impostas pelo programa proposto para atingir seus objetivos. Envolvem, em última escala, a redução do desmatamento por derrubadas, queimadas e, com isso, a redução de emissão de carbono (CO2) que leva ao processo de mudança climática. Na narrativa a seguir apresentada, é possível perceber esta associação e consequente aceitação.

Primeira coisa é que nós não podemos mais desmatar a floresta, e eu apoio isso aí. Sobre 
as outras coisas eu já quase não entendo. Hoje nós não temos mais terra aqui, hoje nós somos morador (...) ninguém pode mais entrar nas florestas como se fazia de primeiro, que a gente entrava nessas matas e, como diz o pessoal, (abusava né?). Hoje não, hoje nós temos uma lei que nós não podemos mais cortar madeira, né? E não se pode ir contra a lei. (Entrevista realizada com morador da comunidade Nova Esperança, 78 anos, em maio de 2011- informação verbal).

Viana (2008) destaca que a região denominada Amazônia Profunda, onde se localiza a RDS do Rio Negro, é caracterizada por uma pequena taxa de desmatamento, inferior a $2 \%$, elevada proporção de áreas protegidas, tais como terras indígenas e unidades de conservação, presença de populações tradicionais e indígenas e dificuldade de acesso por estradas. O programa de incentivo financeiro aos moradores das Unidades de Conservação Estaduais, classificadas como Reservas de Desenvolvimento Sustentável - RDS foi proposta formulada no âmbito da Lei Estadual n. 3.135 sobre Mudanças Climáticas de 05 de junho de 2007, e vem sendo aprimorada desde então.

O auxílio em dinheiro, concedido por meio do Programa Bolsa Floresta, é entendido pelos porta-vozes do governo como um incentivo necessário para que os beneficiários do programa evitem, em suas atividades produtivas, a adoção de práticas que promovam o desmatamento. Pressupõe assim que a conservação das florestas resulta dessas atitudes. Assim sendo, o papel de "guardiões da floresta" é legado a esses moradores de Unidades de Conservação que assumem uma postura pautada na consciência ambiental e se comprometem a não praticar atividades impactantes ao meio em que vivem. Assim, para que prestem esse serviço, o mecanismo contraposto foi o de auxílio financeiro, programas educacionais e também incentivos para que as terras tradicionalmente ocupadas continuem a ser trabalhadas de forma tradicional. 
Entretanto, a efetivação de projetos alternativos para geração de renda depende, em grande escala, de articulação de atividades realizadas pelos comunitários, pois estes precisam prestar contas à Fundação Amazônia Sustentável (FAS), quanto ao emprego de tais recursos que são disponibilizados anualmente para as comunidades que são beneficiárias desse programa. Por tais estímulos, essas comunidades são levadas, pela necessidade, a um processo de organização social e política que muitas ainda não haviam experimentado.

Assim, em comunidades onde se instituíram indivíduos considerados mais proativos, tal como é o caso da comunidade Nova Esperança, esse novo contexto de relacionamento mais próximo com as instituições gestoras da RDS e do Programa Bolsa Floresta tem levado à realização de pequenas melhorias, que beneficiam, de forma geral, a comunidade. Tal é o caso da aquisição de uma antena para o acesso à internet pela escola, mediante recurso do componente Bolsa Floresta Social; e a implantação do horário escolar noturno para atender à necessidade de alfabetização de adultos; bem como o projeto de agregar valor à madeira oriunda do manejo florestal, através da implantação da marcenaria na comunidade, equipada com recursos do componente Bolsa Floresta Renda.

Por outro lado, a dificuldade de articulação interna que levou ao atraso na realização da obra de construção de uma pousada na Comunidade Tiririca, veio a penalizar a comunidade com a não liberação do recurso referente ao exercício 2011 do componente Bolsa Floresta Renda. Essas situações imprimem dificuldades futuras de implantação de novos projetos de geração de renda na comunidade pela FAS. $O$ arrolamento desses fatos denota certa disparidade no cenário de organização social e política das comunidades do polo 01 da RDS do Rio Negro; situação que não se coaduna com um dos objetivos da criação daquela RDS, qual seja: a promoção da melhoria da qualidade de vida desses comunitários como um todo, e não parcialmente. Afinal, o compromisso assumido por eles de desmatamento zero, requer a compensação através da implantação desses tipos de programas. Numa avaliação fundamentada na observação, pode-se argumentar que há fraca articulação entre comunitários 
na elaboração dos projetos gestados por eles; portanto, os procedimentos não se limitam apenas à aprovação ou não dos projetos/ programas, tal como anuncia a normatização que orienta a utilização dos recursos disponíveis junto a FAS.

\section{Considerações Finais}

Posso inferir com base nos relatos aqui apresentados que, se antes o território se instituía a partir dos significados que as identidades coletivas davam a um espaço tornado próprio pelos que a ele se pensavam pertencentes, no contexto político atual, a institucionalidade formal se baseia em significados que a ideia de desenvolvimento preconiza. De modo relativamente velado, esse novo paradigma de desenvolvimento remete mais ao entendimento do que seria, segundo Schweickardt (2001), um "capitalismo domesticado", tecnicamente denominado de desenvolvimento sustentável, que ocorre quando se pretende tratar a ideia de desenvolvimento casada à de conservação dos recursos naturais, sobretudo, os não-renováveis.

Assim, as relações de poder construídas, no âmbito da definição de novas configurações do território e do modo através do qual os habitantes locais devem relacionar-se com essa nova configuração, marcam o contexto atual de gestão nesse município amazônico, cuja principal característica está relacionada a essa nuance da ambientalização e/ou ecologização, conforme assinala Santos (2002).

O que se observa no exemplo da região do Baixo Rio Negro, onde se localiza o município de Novo Airão, é a gestão desse território em relativa conformidade aos preceitos da política ambiental assumida pelo Estado nacional, mas orientada por valores consagrados pela comunidade política internacional. Entretanto, no âmbito estadual, a estratégia do exercício do poder sobre o ordenamento do território encontra, no elemento da compensação por serviços ambientais e através dos programas direcionados aos habitantes de Reservas Estaduais de Desenvolvimento Sustentável, uma forma de alcançar os objetivos da conservação dos recursos. E para tanto, 
associa-se a essa estratégia a melhoria da qualidade de vida das populações tradicionais que habitam nessas reservas.

Até então, no âmbito estadual, o poder estabelecido através dos programas implantados juntos às RDS estaduais tem conseguido atingir às metas de redução do índice de desmatamento, utilizando, para tanto, a estratégia do pagamento por serviços ambientais e o apelo simbólico de se transformar os habitantes locais em "guardiões da floresta". Contudo, a estratégia adotada, pelo menos no âmbito do governo federal, esteve sempre associada ao que Ramachandra Guha (2000) trata como "ecologia profunda". Ele assim qualifica as condições observáveis entre populações que habitam os Parques Nacionais do Jaú e Anavilhanas, além de não serem beneficiárias de nenhum programa dessa natureza, muitas vezes foram submetidas a uma realocação em favor de projetos baseados numa biologia preservacionista.

Ao perceber essas populações como objeto de vigília constante e submetidas a inúmeras restrições quanto ao uso dos recursos naturais que se encontram nas áreas por elas habitadas, desde antes de serem definidas como Áreas Protegidas, nota-se a existência de uma heterogeneidade marcada pelas estratégias adotadas no exercício do poder político no âmbito estadual e federal no que se refere a gestão desse território.

Nesse contexto, em que o exercício do poder político apresenta distintos aspectos, pode-se recorrer a interpretações acenadas por Balandier (1997), quando afirma que o poder na modernidade "leva suas novas inscrições, define suas estratégias, sai à procura de formas melhor ajustadas." (Balandier, 1997, p.20). Sob essa ótica, reafirmo que a dinâmica da gestão territorial na Região do Baixo Rio Negro constitui-se por um cenário complexo: ela retrata justamente a heterogeneidade no exercício do poder e na busca de estratégias mais ajustadas para atingir ao objetivo do ordenamento do território, seja com base na conservação ou na preservação. 


\section{Referências}

AMAZONAS (Estado). LEI n $\mathbf{n}^{\circ} 3.355$ de 26 de dezembro de 2008. Governo do Estado do Amazonas (cria da RDS do Rio Negro e estabelece outras providências).

AMAZONAS (Estado). LEI Ordinária no 3135/2007 de 05 de junho de 2007. Governo do Estado do Amazonas (institui a Política Estadual sobre Mudanças Climáticas, Conservação Ambiental e Desenvolvimento Sustentável do Amazonas, e estabelece outras providências).

BALANDIER, Georges. 0 contorno: poder e modernidade. Tradução de Suzana Martins. Rio de Janeiro: Bertrand Brasil, 1997.

BOURDIEU, Pierre. O poder simbólico. 2. ed. Rio de Janeiro: Bertrand Brasil, 1998.

Guha, Ramachandra. O biólogo autoritário e a arrogância do anti-humanismo. In: Diegues, Antônio Carlos (org.). Etnoconservação: novos rumos para a proteção da natureza nos trópicos. São Paulo: Hucitec, 2000.

SANTOS, Luiz Fernando de Souza. O panóptipo verde: a ambientalização da Amazônia através do Parque Nacional do Jaú. (Dissertação de Mestrado). Manaus: UFAM, 2002.

SCHWEICKARDT, Kátia Helena Serafina Cruz. Um olhar sobre a produção do espaço na Amazônia: os encontros e desencontros entre a política de reforma agrária e a política ambiental no Estado do Amazonas. (Dissertação de Mestrado). Manaus: UFAM, 2001.

SDS - Secretaria de Estado do Meio Ambiente e Desenvolvimento Sustentável. Plano Estadual de Prevenção e Controle do Desmatamento no Amazonas. Manaus, jul.2009. 
SEPLAM-Secretaria de Estado de Planejamento e Desenvolvimento Econômico. Perfil da Região Metropolitana de Manaus. Manaus, 2007.

VIANA, Virgílio. Bolsa Floresta um instrumento inovador para a promoção da saúde em comunidades tradicionais na Amazônia. In: Estudos Avançados. v.22, n.64. São Paulo: Dez. 2008. 


\section{IX}

\section{Rearranjos locais no programa de reforma agrária: estudo de caso do P.A. Che Guevara (Campos Dos Goytacazes, Rj)}

Rodrigo Pennutt da Cruz ${ }^{69}$

A partir das últimas décadas do século XX, a atividade agroaçucareira no norte do Estado do Rio de Janeiro passou por uma série de mudanças, boa parte delas decorrentes, entre outros fatores, de insolvências de unidades produtivas. Esses sucessivos processos falimentares não se limitaram à região açucareira de Campos. Eles vêm sendo caracterizados como crises no respectivo setor produtivo, não só referentes ao plano estadual, como também ao nacional.

Para essas transformações concorreram, no caso do Estado do Rio de Janeiro, tal como explicitados publicamente, radicalizados confrontos de interesses, entre fornecedores de cana e usineiros, e destes com os dos trabalhadores, muitos deles do setor agrícola, para tanto mobilizados e referenciados por ideários de movimentos sociais cujos porta-vozes eram dirigentes do Sindicato dos Trabalhadores Rurais (STR), do MST (Movimento dos Trabalhadores Rurais Sem-Terra) ou da CPT (Comissão Pastoral da Terra). Desses confrontos, entre outros resultados, ocorreram desapropriações de terra anteriormente pertencentes a fornecedores de cana, ou usineiros, por tais procedimentos absorvidas pelo Programa Nacional de Reforma Agrária. E por essas intervenções,

69 Mestrando pelo Programa de Pós-Graduação em Antropologia - PPGA/UFF Bolsista CAPES.rpennutt@gmail.com 
configurou-se uma reordenação do espaço social e geográfico da região. Reafirmou-se, de maneira diferenciada, a ampla presença de pequenos estabelecimentos agrícolas, agora também na condição de lotes de assentamentos rurais, todos então coexistindo com grandes fazendas, algumas secularmente reproduzidas nessa posição.

De acordo com levantamento realizado nos arquivos do INCRA (Instituto Nacional de Colonização e Reforma Agrária), foram criados, nesta região, a partir de 1987, 10 assentamentos rurais que, juntos, abarcam área de 17.739,9994 ha e suportam 1.167 famílias (Quadro 1).

\section{Assentamentos existentes no município de Campos dos Goytacazes}

\begin{tabular}{lccc}
\hline Projeto de Assentamento & Ano de criação & Área (ha) & № de famílias \\
\hline Novo Horizonte & 1987 & $4.335,1000$ & 285 \\
Zumbi dos Palmares & 1997 & $8.005,2900$ & 507 \\
Che Guevara & $\mathbf{2 0 0 0}$ & $\mathbf{1 . 1 1 9 , 6 6 2 0}$ & $\mathbf{7 4}$ \\
Ilha Grande & $\mathbf{2 0 0 1}$ & $\mathbf{8 2 2 , \mathbf { 2 1 8 }}$ & $\mathbf{5 8}$ \\
Antônio de Farias & 2001 & $1.221,0230$ & 93 \\
Terra Conquistada & 2005 & 211,570 & 15 \\
Dandara dos Palmares & 2005 & 419,027 & 25 \\
Santo Amaro & 2005 & 584,3770 & 40 \\
Oziel Alves I & 2006 & 410,7336 & 35 \\
Josué de Castro & 2007 & 610,9988 & 35 \\
Total & & $\mathbf{1 7 . 7 3 9 , 9 9 9 4}$ & $\mathbf{1 . 1 6 7}$ \\
\hline
\end{tabular}

Quadro - Dados obtidos na Superintendência Regional do Rio de Janeiro no ano de 2009. (Tabela organizada pelo autor)

Fonte- Instituto Nacional de Colonização e Reforma Agrária (INCRA).

Esse é o cenário no qual coloco, em prática, esta pesquisa, cujos dados referenciam a delimitação do objetivo deste $\operatorname{artigo~}^{70}$. Para

70 - A pesquisa corresponde aos pré-requisitos para elaboração de dissertação de mestrado junto ao PPGA-UFF, ao qual me encontro afiliado como mestrando, vinculado a projeto mais amplo, coordenado pela Prof ${ }^{\mathrm{a}}$. Dr ${ }^{\mathrm{a}}$. Delma Pessanha Neves. 
defini-lo, levo em consideração alguns dos meandros da aplicação do Programa Nacional de Reforma Agrária, considerando, em especial, as interferências e negociações decorrentes dos percursos de relações vividos pelos trabalhadores selecionados para alcançarem a condição de assentados no Projeto de Assentamento (P.A.) Che Guevara.

No processo de aplicação de política pública de redistribuição de terra, fundamentada em quadros institucionais diferenciados e objetivados por Projetos de Assentamento, por perspectiva simplificada, tem-se como dada a construção da categoria situacional assentado. Se há definições oficiais, constantes de documentos que registram e pressupõem normatizar o processo de assentamento, há condições possíveis e até imprevistas de realização. Nelas, incidem, entre outros fatores, os meios de produção transferidos por desapropriação de fazendas; a proximidade de mercados de produtos e serviços, bem como de trabalho, posto que acenem com alternativas de composição de rendimentos paralelos à constituição do produtor independente; de demandas de mercado de produtos agropecuários; de presença de serviços públicos, especialmente de saúde e de ensino básico. Esses fatores operam na constituição de uma gama de conquistas ou constrangimentos correspondentes ao processo de constituição do agricultor assentado. Mas ainda, mesmo que poucas vezes contempladas pela pesquisa acadêmica, operam segundo as experiências anteriores dos trabalhadores selecionados para alcançarem a condição de assentado. Em alguns casos, há aproximações na integração de candidatos com trajetórias distintas. Em outros, há conflitos pelo questionamento da legitimidade da entrada de certos candidatos concorrentes, que não correspondem aos padrões de justificativa social da população e de trabalhadores residentes na ou no entorno da fazenda desapropriada.

Neste artigo, empenho-me em analisar como tais encontros e desencontros de experiências podem gerar conflitos e impor convivências tensas, expandindo assim a base de constituição do 
assentamento conforme negociações, rejeições ou superdimensionamento de certas experiências passadas. Esses conflitos e negociações, mesmo que não planejados no escopo da normatização das condições de aplicação dos programas de assentamento vinculados às políticas públicas de reforma agrária e da definição do correspondente agrícola, terminam por contribuir decisivamente na constituição diferenciada de projetos de assentamento e definição do assentado, bem como de espaços institucionais de mediação básicos ao exercício da referida política pública.

Em outros termos, ao adotar tais questões como objeto de reflexão neste artigo, pretendo contribuir para o entendimento de processos pelos quais os trabalhadores rurais de origens diversas se deslocaram para a posição de assentados rurais; ou seja, conquista fundamentada no aprendizado de vinculação a campos de disputa e negociação como agentes políticos.

Por tal perspectiva, levo em conta os fatores ressaltados pelos assentados do P.A. Che Guevara como expressivos das transformações por eles vividas. E entre tais fatores, também valorizo a importância analítica dos diferenciados e concorrentes princípios de afiliação que eles ressaltam para se distinguir, a despeito do paralelo exercício de reconhecimento da conquista da posição comum de assentado, a que todos, por caminhos diferenciados, devem, em tese ou oficialmente, corresponder.

Para o entendimento de processos de construção da mudança da posição social de assalariados rurais para assentados, muitas são as alternativas e perspectivas teóricas. Até porque, o estudo de processos de mudanças sociais é tema considerado direta ou tangencialmente pelos múltiplos aportes teóricos que foram se constituindo diante da preocupação de compreender o caráter dinâmico da sociedade, especialmente a industrial.

No decorrer do texto, vou explicitando as opções por mim adotadas, isto é, considerando não só algumas daquelas contribuições da teoria sociológica ou antropológica, mas também questões valorizadas para a compreensão do tema em foco: condições de participação dos contemplados em programas públicos que também moldam as alternativas da respectiva implementação. Centro-me assim na reflexão sobre deslocamentos por ações de agentes 
sociais diferencialmente posicionados, mas principalmente daqueles vistos como receptores. Ao tomar tal perspectiva, evito cair em abstrações vinculadas a mudanças de sistemas ou de totalidades inventadas, afiliadas à crença que os ideários e proposições de políticas públicas possam se tornar realidades determinadas, tais como fundamentadas em abstratas intervenções do Estado, pressupondo operações a partir de um ponto zero onde tudo começou e a partir do qual tudo mudou (NEVES, 1994, p. 49-74).

\section{Condições situacionais de construção dos assentados}

O município de Campos de Goytacazes estruturou-se com base na produção de cana-de-açúcar e na concentração da propriedade da terra, inicialmente em mãos de sesmeiros, nos tempos atuais por grandes produtores (NEVES, 1981, 1997a; CRUZ, 2010).

Nas situações de mudanças inerentes aos processos de falência ocorridos na região, têm sido criadas alternativas de trabalho por outras formas de inserção produtiva ou por reconversão de trabalhadores rurais, expressas tanto pelos que aderiram à luta pelo acesso a terra, como pelos que se negaram a integrar processos de assentamentos ${ }^{71}$ tem-se constituído um dos objetivos do trabalho de pesquisa que venho realizando entre trabalhadores rurais da região. Considero as condições sociais de trabalhadores assalariados, vendedores de força de trabalho, para a de produtores agrícolas mercantis, isto é, agricultores que controlam fatores de produção e produtos do trabalho direto. Nessa condição, eles são detentores de possibilidades de tomada de decisões quanto à gestão da unidade produtiva e alocação de trabalho familiar, além da gestão em favor da circulação mercantil do produto de seu trabalho agrícola.

71 É importante destacar que há um representativo segmento de trabalhadores que, por motivos diversos, não se integraram ao Programa Nacional de Reforma Agrária. Recompuseram as relações de trabalho assalariado, tanto pela reafirmação do vínculo como cortadores de cana, como também trabalhadores da indústria de cerâmica, ou mesmo em atividade de economia de proximidade e serviços públicos municipais. 
Na formação desse novo cenário de oportunidades produtivas, os trabalhadores que aderiram ao Programa Nacional de Reforma Agrária constituíram-se em agentes políticos e econômicos com trajetórias distintas. Portanto, investimentos específicos para construção de identidades unificadas e diferenciadas. Neste último caso, autovalorizando-se pelo fato de terem sabido se valer e lutar pela incorporação de alternativas de acesso a terra, mesmo que, anteriormente, estivessem vinculados a outros setores produtivos (construção civil, comércio ambulante, costura) ou fazendas pecuárias.

$\mathrm{Na}$ construção de questões analíticas referentes a esses processos, venho ressaltando, sob caráter relacional, os custos em investimentos políticos de trabalhadores da desapropriada fazenda da usina e adjacências vis a vis os assentados oriundos de outros setores produtivos. Exatamente porque se integravam tradicionalmente ao cultivo da cana, querem se diferenciar como assentados privilegiados, como enraizados culturalmente na região correspondente ao setor sucroalcooleiro; e não querem, diante do processo de assentamento, serem imediatamente confundidos como eles, desqualificadamente, denominam como os de fora. E por essa posição, estes últimos são vistos como forasteiros que se impuseram no espaço social da fazenda da usina desapropriada para fins de constituição do projeto de assentamento.

Os princípios de distinção construídos no bojo dessas relações referenciadas à contraposição dos que são de dentro ou de fora, pelo menos da perspectiva dos primeiros, ressaltam atributivamente a distinção e nobreza pelo fato de serem eles considerados antigos funcionários da usina72. Definem-se como trabalhadores que nasceram na localidade que sedia o assentamento rural em pauta, mas não só. Tendo aí permanecido após a falência da usina, de certa

72 É importante observar que a categoria funcionário não corresponde à posição que estes trabalhadores possuíam no período de funcionamento do Complexo Agroindustrial. Os trabalhadores rurais eram qualificados como agrícolas ou cortadores de cana. Os funcionários eram considerados aqueles que exerciam funções administrativas no escritório da usina. A distinção estabelecida no atual contexto contrapõe-se, significativamente, aos de fora, oriundos do MST. 
forma, redefiniram e reproduziram vínculos de pertencimento no universo social também no mesmo bojo redimensionado. Mesmo negando a presença constitutiva da usina pela legitimação das novas condições dos decorrentes apropriadores, a vida nesse espaço foi reconcebida por permanente trabalho de memorização dos que, permanecendo, assistiram à constituição de sucatas industriais. Os trabalhadores inventaram, assim, formas novas de reciprocidade e economia de proximidade, mas também a redefinição do destino produtivo da terra diante da ocupação por trabalhadores afiliados ao MST.

Apresentando-se como portadores de conhecimento profundo sobre a região, comprovado, inclusive, pela reafirmação dos vínculos anteriores com a usina, os ex-trabalhadores reivindicam direitos especiais, em contraposição aos que foram recentemente assentados pela condição de acampados. Estes se constituíram como agentes em concorrência diante do acesso a um lote de terra, mesmo que, agora, o critério de redistribuição fosse diferente, postulado segundo critérios do Programa Nacional de Reforma Agrária; ou mesmo que os sinais distintivos da valorização dos que tiveram coragem de ocupar fossem as formas de lutas lideradas por representantes do MST.

Em apoio político aos antigos funcionários da usina e diante da condenada presença dos desqualificados forasteiros, à composição dos demandantes da condição de assentados, vieram se agregar outros trabalhadores para adquirirem um lote de terra, porque continuaram residindo próximo à antiga área da fazenda. Enquanto privilegiados espectadores, mas vizinhos na maior parte das situações, definem-se como críticos em relação aos desdobramentos sociais que a ocupação por afiliados ao MST veio a configurar.

Por essas distinções e resumindo para facilitar a apreensão pelo leitor, afirmo que no sistema de posições se integram relacionalmente e em contraposição: os de fora ou sem terra (aqueles que chegaram ao local via MST, participaram de todo o processo de acampamento e não possuíam qualquer tipo de vínculo, pelo menos aparente, com a população e as atividades produtivas locais); os antigos funcionários da usina e os moradores de Marrecas (localidade em torno do assentamento). 
Adotando tal objeto de reflexão, desejo contribuir para a compreensão de condições imprevistas de realização do Programa de Reforma Agrária, mas no que tangem à objetivação de processos de assentamento. Mesmo que por tal programa se postule o reconhecimento social, político e jurídico do beneficiário como assentado, a conquista dessa condição e a categorização socioeconômica ou socioprofissional correspondem a processos de negociações sui generis; mas só a atenção aos modos como agentes reais se mobilizam para se constituir, na posição, pode permitir compreender alguns dos meandros da objetivação de tais programas públicos. Sendo expressão tecnicamente imprevista dos processos de constituição de sujeitos políticos, ela, em verdade, só pode ser assim entendida quando se considera que a realização local dos programas de reforma agrária é ato imediato. Ou, ainda mais, que ela deve corresponder apenas a um acúmulo de conquistas e ganhos, cuja expressão mais acabada ressalta a progressiva melhoria das condições de vida e da relativa autonomia. A desconsideração desses meandros também constrói a invisibilidade da diferenciação socioeconômica constitutiva dos assentados, muitas vezes explicadas por avaliações morais que distinguem o bom e o mau assentado.

Tal como já destacou Neves (1997b), ao estudar outro processo de assentamento nessa região açucareira, a despeito de programa de assentamento rural se definir por uma série de procedimentos, normas, critérios de distribuição de recursos e demonstração de adesões por parte dos trabalhadores assim integrados, a coerência que tal programa, desta condição, deve fazer aparecer, pouco tem a ver com as possibilidades de sua realização, posto que ele não opera num vazio de relações, entre trabalhadores dotados de habitus social (BOURDIEU, 1998) correspondente a trajetórias próprias. E assim, por perspectivas diferenciadas quanto aos efeitos do controle privado de um lote de terra. Por tais razões, o estudo do processo de assentamento, enquanto expressão de percursos de objetivação do programa de reforma agrária, não pode prescindir de perspectiva analítica processualista, também incluindo a valorização de fatores situacionalmente intervenientes, modos de viver institucionalizados e experiências alcançadas em processos de mudanças sociais. 


\section{Formas diferenciadas de poupança na constituição do assentado}

Para exemplificar as condições diferenciadas de constituição do ser assentado, destaco as maneiras imperativas ou relativas de acesso ao crédito, demonstrações cabais de como esses lidam com os programas voltados para o desenvolvimento econômico e social destinados à manutenção do assentamento. No caso em análise, os assentados do P.A. Che Guevara receberam como "auxílio" o crédito rural (Pronaf ${ }^{73}$ - Programa Nacional de Desenvolvimento da Agricultura Familiar; Crédito de Instalação ${ }^{74}$ ).

A obtenção do crédito rural é percebida, tanto entre os assentados como entre os agentes externos (funcionários de instituições públicas, como INCRA, EMATER - Empresa de Assistência Técnica e Extensão Rural) enquanto momento em que os primeiros estabelecem um diálogo com o Estado. E, em alguns casos, também o primeiro contato com transações bancárias.

Este é um dos momentos de demonstração da diferenciação entre os assentados, pois alguns, principalmente os denominados antigos funcionários da usina, em sua maioria, não acessaram o Pronaf. Contaram com as indenizações trabalhistas para iniciarem as atividades em seus lotes. Diferentemente dos demais que, por falta de alternativas, recorreram ao recurso (denominado por eles como "empréstimo") para constituição das atividades agrícolas. Estes, por recomendações dos próprios técnicos da EMATER, não acessaram o valor total do crédito, de imediato. Segundo um dos funcionários da empresa estatal que acompanhou o processo, esta sugestão foi dada, na época, como uma forma de precaução, para que os assentados não iniciassem suas atividades agrícolas endividados, pois havia, por parte do técnico, receio de que não conseguissem arcar com as dívidas.

Por outro lado, a forma de utilização do crédito não seguiu, à risca, os projetos desenvolvidos pelos técnicos da EMATER. Como

73 - Este programa tem como objetivo financiar projetos individuais ou coletivos, que gerem renda aos agricultores familiares e assentados da reforma agrária.

74 O Crédito Instalação consiste no provimento de recursos financeiros, aos beneficiários da reforma agrária, para instalação e desenvolvimento inicial. 
exemplo, cito o caso de um assentado que, por iniciativa própria, decidiu não cultivar coco, pois, por experiência na agricultura, temia que tal fruta não fosse de fácil comercialização (vantajosa economicamente), inclusive com demora do tempo para a colheita, uma vez que não é imediata.

Já o "Crédito de Instalação", administrado pelo INCRA, recebeu adesão de todos os assentados. Os de fora utilizaram este crédito para construção das casas em que residem no interior do assentamento. Os antigos funcionários da usina, como já dito, possuindo residências no vilarejo próximo ao assentamento, utilizaram o lote apenas para produção agrícola e não para morada. As construções existentes em seus lotes são utilizadas, em geral, para guardarem as ferramentas de trabalho e espaços para descansos durante a jornada de trabalho.

Esses "benefícios", recebidos no momento inicial da constituição do assentamento, incentivam os participantes da Política de Reforma Agrária a integrar um "novo saber fazer", voltado para a ação nos espaços institucionais, como salienta Leite:

Nesta nova condição, de assentado-produtor rural, pesam sobremaneira os meios disponíveis às atividades produtivas (incluindo instalações, máquinas, equipamentos, implementos e insumos), o conhecimento sobre técnicas e procedimentos empregados e o acesso às políticas públicas de assistência técnica e ao crédito rural (LEITE, Sérgio, 2004, p.193).

Esse "novo saber fazer" delineia as possibilidades e, em alguns casos, impossibilidades de constituição do assentado. As opções incorporadas no momento do acesso ao crédito podem estar fortemente influenciadas pelos percursos e recursos familiares. Consequentemente, demarcam o processo de distinção entre eles, ou mesmo a diferenciação interna. 


\section{Formas diferenciadas de participação nas lutas políticas}

Os assentados só se constituem nessa posição pelo aprendizado em ações coletivas, redimensionando a importância do conflito, destaco as lutas de classe, correspondentes à demanda da transferência da terra do usineiro falido ou fazendeiro improdutivo para os trabalhadores rurais, mas também o caráter conflitivo das relações que configuram o assentamento, considerando, como venho destacando, os processos e alternativas de construção de interesses contrapostos entre assentados.

A falência é a explicitação máxima desses confrontos, mesmo que podendo até ser pensada como a única saída ainda vantajosa para o usineiro em causa. É fato que o processo falimentar não ocorreu por contraposição imediata dos interesses dos trabalhadores, mas também por disputas entre usineiros e agentes do Estado no que tangem às condições de intervenção e capitalização dos empresários. É o caso, por exemplo, de distintos investimentos de instituições do aparato estatal, muitas vezes uma operando por objetivos diametralmente opostos à outra. No caso, também pela impositiva alteração de práticas das instituições estatais, num contexto de adesão ao modelo de capitalismo neoliberal, que criou outras formas de valorização do capital financeiro, em detrimento das regras que repunham as condições de capitalização dos usineiros.

Demonstrando um dos desdobramentos possíveis, quando o contexto de democratização da sociedade brasileira acenava para a retomada da Política Nacional de Reforma Agrária e criava possibilidades de autorização dos trabalhadores rurais como demandantes de redistribuição fundiária, é preciso levar em conta que outras formas de construção de espaços geográfico-sociais foram possíveis. No caso aqui considerado, houve inserção de outros agentes políticos favoráveis à reforma agrária, no campo das desejadas transformações sociais, tais como a institucionalização de assistência técnica e formulação de política creditícia para construção do assentado como produtor agrícola, propiciando a padronização de residências concedidas mediante créditos especiais. 
Portanto, a criação de um assentamento rural engendra e é engendrado pela entrada de novos agentes, tais como funcionários do INCRA, EMATER e militantes do MST. Eles se apresentam como posições referenciais para a constituição de novas estruturas de poder e quadros institucionais de inserção ou de definição de princípios de afiliação ou pertencimentos sociais. Essa entrada de novos agentes redimensiona os sistemas de relações pessoais até então existentes, cujas modificações são bastante dramatizadas no plano local.

As relações que dão objetividade ao assentamento rural estão assim permeadas por interesses múltiplos, tanto para confirmação da vida social segundo projetos ou projeções próprias de organização social, como também por negociações com o mundo institucional externo, pelo qual em grande parte o assentamento se estrutura. Por conseguinte, o que está em jogo em processos que exprimem tais mudanças sociais são sistemas de posições construídos ou redefinidos mediante elaboração de outras identidades sociais e princípios de afiliação e de reconhecimentos sociais.

Em assim sendo, o estudo do processo de mudança de trabalhadores em assentados rurais se associa ao das condições de construção relacional e situacional de identidades sociais, todavia relativizadas como expressão de relações de força e de sentido que aí se encontram em jogo. Segundo a definição de identidade elaborada por Dubar (2009), por mim valorizada para melhor compreender as alternativas de compreensão dos dados apreendidos em trabalho de campo:

... a identidade não é o que permanece necessariamente "idêntico" mas o resultado de uma "identificação" contingente. É o resultado de uma dupla operação linguageira: diferenciação e generalização. A primeira é aquela que visa a definir a diferença, o que constitui a singularidade de alguma coisa ou de alguém relativamente a alguém ou a alguma coisa diferente: a identidade é a diferença. A segunda é a que procura definir o ponto comum a uma 
classe de elementos todos diferentes de um mesmo outro: a identidade é o pertencimento comum. Essas duas operações estão na origem do paradoxo da identidade: o que há de único é compartilhado. Esse paradoxo só pode ser solucionado enquanto não se leva em conta o elemento comum às duas operações: a identificação de e para o outro. Não há, nessa perspectiva, identidade sem alteridade. As identidades, como as alteridades, variam historicamente e dependem de seu contexto de definição. (DUBAR, 2009, p.13, grifos do autor)

E aí novamente se aguçam os efeitos dos distintos percursos dos assentados. A aludida diferença é acentuada no contexto em que os ex-funcionários se percebem e investem para serem reconhecidos distintos dos de fora ou dos sem-terra. E estes, no sentido de mostrar a imprescindibilidade de seu papel político na organização social da reivindicação por terra e da terra do usineiro falido, adotando procedimentos construídos pelo modelo de ação que Sigaud et al. (2010) qualificaram como forma de ocupação, forjada na luta daqueles que aderem aos princípios de organização do MST. Sem ocupação, advogam os qualificados de fora, não haveria desapropriação e programa de assentamento. Sem este agente ali desenraizado, mas construído por referências que não se pautavam na adesão às formas de dominação postas em prática pelos usineiros, os ex-funcionários da usina não haveriam se convertido em assentados. De qualquer forma, compreendendo as contraposições como formas de valorização de ações interdependentes, a ação conjunta dos dois agentes assim polarizados construiu o contorno dos processos em jogo.

No entanto, há agregação de esforços e investimentos e eles só se tornam mais compreensíveis pelo entendimento das trocas de saberes entre eles, tal como eles próprios ressaltam. Para uns, o saber ambiental e dos processos históricos ali configurados. Para outros, o aprendizado da rebeldia, da ruptura, da construção de 
si como agente da história e de seus projetos de sociedade. Essas contrapostas, mas complementares percepções de si e do outro, ainda são comungadas por aqueles que, à primeira vista, são levados a assumir a mesma identidade, mesmo que não se vejam como partes daquelas posições polarizadas. Refiro-me às relações entre os antigos funcionários que foram beneficiados pelo projeto de assentamento e os que não participaram de tal possibilidade, mas ali permaneceram reafirmando um mundo social em mudança e estabelecendo as relações de troca para consumo imediato dos produtos de subsistência, que os assentados passaram a oferecer; ou aos que, dotados de pequenos negócios, em substituição à centralidade dos antigos fornecimentos de usinas, também, mediante a construção de relacionamentos pessoais, asseguram crédito para provisão nas vendas locais, como demonstra a expansão do comércio nessa economia de proximidade.

\section{Considerações Finais}

É importante salientar, embora lugar comum, que as identidades não são fixas. Elas podem ser ressignificadas, segundo interesses diversos, constituídos e em constituição relacional. Isso é claramente percebido no contexto de análise, uma vez que os antigos trabalhadores da usina valem-se de tal categorização como forma de legitimar a permanência no local, mas principalmente de se definirem como beneficiários que devem ser privilegiadamente atendidos por esta própria antiga inserção.

Entretanto, quando concorrem a direitos relacionados ao assentamento ou a interesses coletivos, eles deixam de lado as diferenças e se irmanam como assentados, secundarizando ou mesmo subtraindo aquela distinção.

As marcações ritualizadas das distinções já consideradas instigam o pesquisador a compreender, tal como o fez Geertz (1999) em estudo realizado nas aldeias balinesas, os princípios de afiliação ou pertencimento em jogo, que dão sentido à vida social e organizacional do grupo em foco: 
Em um caso como esse, em que é necessário admitir que o entrecruzamento dos grupos sociais é extremo, o problema da integração, dos ajustamentos mútuos entre os grupos, é muito preeminente. Às vezes desencadeiamse lutas abertas entre líderes de vários grupos sobre a questão de quem detém os direitos prioritários aos serviços dos membros (GEERTZ, 1999, p.293).

Aquelas concepções em conflito, amenizadas pela necessária reciprocidade constitutiva do sistema de posições, foram por mim valorizadas para refletir sobre o caso em apreço. E ressaltam as disputas pelo reconhecimento da importância alcançada pelos detentores de conhecimentos necessários para o desenvolvimento do assentamento, que não podem se pautar somente no saber local. Tais conhecimentos exigem incursões pelos caminhos da burocracia estatal, da aceitação e questionamento de regras inerentes ao programa de assentamento, enfim, agentes mediadores que fazem viver, nesses espaços, os interesses supostamente de todos, inclusive dos que querem se ver privilegiados na apropriação de recursos que conformam o processo de assentamento.

Assim, a construção do assentamento pode ser melhor entendida pela perspectiva das múltiplas situações sociais que ali se conformam, sendo antes de tudo um campo de disputa, resultado e produtor de mudanças sociais, espaço de negociação de uma série de conflitos e interferências internas e externas, contudo passível de acordos diante da busca da legitimação, procedimento constante ou mesmo inesgotável entre os assentados.

A própria forma com que eles lidam com as identidades construídas e em construção é fator atuante nos processos de mudanças. Sem dúvida alguma, são esses conflitos que estão a alimentar outras formas de ser socialmente, percepções que serão posteriormente examinadas como mudanças, tanto pelos agentes diretos como por pesquisadores por virem. Isso impede de se fixar um perfil para os assentados, de se homogeneizar posições 
e tendências. Mas princípios de diferenciação sinalizam os múltiplos espaços de construção de poder e disputa pela consecução de interesses, também construídos situacionalmente, como são exemplares os anteriores trabalhadores de usina, hoje ex-funcionários de usina, contudo, de fato, posição apenas existente no contexto de construção do assentamento rural.

Ressaltei, portanto, aspectos ou pontos de objetivação e interseção no processo de construção do assentamento rural, ou seja, com a recorrência dispersamente percebidos na Política Nacional de Reforma Agrária. Espero ter demonstrado uma das condições de realização ou até irrealização de objetivos tão amplos, mas necessariamente propagados pelos que defendem políticas públicas de reordenação fundiária na sociedade brasileira. 


\section{Referências}

BERGAMASCO, Sônia Maria. P. P; NORDER, Luiz A. C. Assentamentos e assentados no Estado de São Paulo: os debates e as categorias inerentes à constituição dos programas de reforma agrária. In.: NEVES, Delma P. (org.). Desenvolvimento social e mediadores políticos. Porto Alegre: Ed. UFRGS, 2008.

BOURDIEU, Pierre. O poder simbólico. 2. ed. Rio de Janeiro: Bertrand Brasil, 1998.

CRUZ, Rodrigo Pennutt da. Marreca de ponta à cabeça: estudo do processo de constituição do P.A. Che Guevara (Campos-RJ) a partir da diferenciação socioeconômica. (Monografia apresentada à Coordenação do curso de Graduação de Ciências Sociais-UFF. Niterói jul. 2010.

DUBAR, Claude. A crise das identidades: a interpretação de uma mutação. São Paulo: EDUSP, 2009.

LEITE, Sérgio et al. Impactos dos assentamentos rurais: um estudo sobre o meio rural brasileiro. Estudos NEAD, n. 6. São Paulo: Editora UNESP: Brasília: NEAD, 2004.

LIMA, Graziela C. D. O "sujeito da reforma agrária" e a constituição de mediadores. In.: NEVES, Delma P. (org.). Desenvolvimento social e mediadores políticos. Porto Alegre: Ed. UFRGS, 2008.

MEDEIROS, Leonilde S; LEITE, Sérgio et al. Luta por terra e assentamento rural no estado do Rio de Janeiro. In.: ----------------; (orgs.). A Formação dos Assentamentos Rurais no Brasil: processos sociais e políticas públicas. Porto Alegre; Rio de Janeiro: Ed. Universidade UFRGS/CPDA, 1999. 
NEVES, Delma Pessanha. Diferenciação sócio-econômica do campesinato. In Revista Ciências Sociais Hoje. ANPOCS: Ed. Cortez, p.220-241, 1985.

Por trás dos verdes canaviais. Niterói: EDUFF, 1989.

. Mudança Social: exorcizando fantasmas. In.: Antropolítica. n.1, jan/jun. p. 49-74, 1995.

Os fornecedores de cana e o estado intervencionista: estudo do processo de constituição social dos fornecedores de cana, no contexto de intervenção do Estado e da consolidação da interdependência entre agricultura e indústria, na região açucareira de Campos (RJ). Niterói: EDUFF, 1997a.

Assentamento rural: reforma agrária em migalhas. Niterói: EDUFF, $1997 b$.

SIGAUD, Lygia et al. Ocupações e acampamentos: sociogênese das mobilizações por reforma agrária no Brasil. Rio de Janeiro: Garamond, 2010. 

O conjunto de textos agregados nesta coletânea incide sobre reflexões em torno do tema políticas públicas, a partir de investimentos de pesquisa, demonstrativos dos múltiplos espaços de definição de regras para circulação de recursos e de formulação de ideários voltados para construção de comportamentos esperados. Por eles, valoriza-se a criação de redes interdependentes de aparatos institucionais correspondentes aos objetivos delineados. Considera-se ainda a formação de agentes sociais capazes de operar na formulação e realimentação de ideias que permitam que os objetivos sejam reconhecidos na capilaridade das práticas cotidianas.

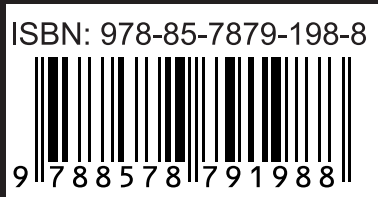

